UNIVERSIDADE DE SÃO PAULO

FACULDADE DE FILOSOFIA, LETRAS E CIÊNCIAS HUMANAS DEPARTAMENTO DE GEOGRAFIA

PROGRAMA DE PÓS-GRADUAÇÃO EM GEOGRAFIA HUMANA

KETLIN ELISA THOMÉ WENCESLAU FIOCCO

A oralidade e a elaboração de conceitos no processo de aprendizagem de Geografia na Educação Básica

Versão Corrigida

SÃO PAULO

2017 


\section{A oralidade e a elaboração de conceitos no processo de aprendizagem de Geografia na Educação Básica}

Dissertação apresentada ao

Programa de Pós-Graduação em

Geografia Humana do

Departamento de Geografia da Faculdade de Filosofia, Ciências e Letras da Universidade de São Paulo, para obtenção do título de Mestre em Geografia.

Área de Concentração: Ensino de Geografia

Orientadora: Prof. $^{\mathrm{a}}$ Dr. ${ }^{\mathrm{a}}$ Maria Eliza Miranda

Versão Corrigida

De acordo,

Prof. ${ }^{\mathrm{a}}$ Dr ${ }^{\mathrm{a}}$ Maria Eliza Miranda

SÃO PAULO 
Autorizo a reprodução e divulgação total ou parcial deste trabalho, por qualquer meio convencional ou eletrônico, para fins de estudo e pesquisa, desde que citada a fonte.

Catalogação na Publicação

Serviço de Biblioteca e Documentação

Faculdade de Filosofia, Letras e Ciências Humanas da Universidade de São Paulo

A oralidade e a elaboração de conceitos no

F5170 processo de aprendizagem de Geografia na Educação Básica / Ketlin Elisa Thomé Wenceslau FIOCCO ; orientadora Maria Eliza MIRANDA. - São Paulo, 2016.

$185 \mathrm{f}$.

Dissertação (Mestrado) - Faculdade de Filosofia, Letras e Ciências Humanas da Universidade de São Paulo. Departamento de Geografia. Área de concentração: Geografia Humana.

1. Oralidade. 2. Leitura e escrita. 3. Ensino de Geografia. 4. Sequência Didática. 5. Elaboração de conceitos. I. MIRANDA, Maria Eliza, orient. II. Título. 
Nome: FIOCCO, Ketlin Elisa Thomé Wenceslau

Título: A oralidade e a elaboração de conceitos no processo de aprendizagem de Geografia na Educação Básica

Dissertação apresentada à Faculdade de Filosofia, Letras e Ciências Humanas da Universidade de São Paulo, para obtenção do título de Mestre em Geografia Humana.

Aprovado em: 12016.

Banca Examinadora:

Prof. ${ }^{\text {a }}$ Dr ${ }^{\mathrm{a}}$. Maria Eliza Miranda (Orientadora) Instituição: FFLCH-USP Julgamento: Assinatura:

Prof. ${ }^{a}$ Dr ${ }^{a}$. Zilda Gaspar de Oliveira Aquino Instituição: FFLCH-USP Julgamento: Assinatura: Assinatura: 


\section{DEDICATÓRIA}

A todos os meus alunos, em especial aos que participaram desta pesquisa, que muito me ensinaram sobre o significado da mediação no ensino e aprendizagem da Geografia. 


\section{AGRADECIMENTOS}

A Deus, por me sustentar e me orientar em todos os momentos da minha vida, em especial durante os anos dedicados ao Mestrado.

Aos meus pais Carmen e Benedito pelo exemplo, apoio e amor incondicional em toda a minha vida.

Ao Rodolfo, meu esposo, pelo apoio, companheirismo, orgulho e amor no meu caminho acadêmico de muito aprendizado para nós dois.

Ao Vinicius, meu irmão que amo tanto e que me possibilitou aprender muito sendo sua professora na Educação Infantil e posteriormente no Ensino Fundamental.

À Ana Luiza, minha sobrinha, irreverente e amada, a representante da relação mais intensa com o meu irmão Guilherme, de quem sinto tanta saudade.

À Clélia, minha tia tão querida que sempre esteve presente e me apoiou em meus estudos ao longo da minha vida.

À minha orientadora Professora $\operatorname{Dr}^{\mathbf{a}}$ Maria Eliza Miranda por me apresentar outros referenciais para pensar a educação e por seu exemplo incansável de mediação intensa movida por uma crença no ser humano, a qual muito me desafia e me impulsiona.

À Prof. ${ }^{a}$ Dr ${ }^{a}$. Marisol Barenco de Mello pela participação na banca do meu Exame de Qualificação para o mestrado e as preciosas indicações de leitura.

À Luciana Martins minha amiga, muito obrigada por compartilhar sua vida, amizade e companheirismo, me sinto privilegiada por tê-la conhecido.

À amiga Daniela Paulo, minha gratidão pela amizade sincera e apoio indispensável na revisão do texto desta dissertação.

Ao Francis Macedo, pelas leituras e contribuições nas reflexões do texto desta dissertação.

Ao Ivan Mota pelo apoio normativo nas transcrições dos turnos de Debate Regrado.

À Luiza pelo apoio e disponibilidade quanto aos dados de pesquisa gerados por meio do software.

Aos integrantes do Círculo de Estudos e Pesquisas para a formação de professores, que participaram das intensas, reflexivas e longas reuniões aos sábados entre agosto de 2010 e dezembro de 2014, por compartilharmos nossas fragilidades e potencialidades e assim nos desenvolvermos mais.

À professora Viviane Pavanello, pela disponibilização sem limites dos livros da Sala de Leitura da Emef Etchegoyen para as minhas pesquisas do Mestrado. 
Aos professores Chicco Mello e Samantha Fernandes pelo apoio indispensável nas traduções dos textos em francês e inglês.

À minha amiga Daniela Marcondes pela amizade e apoio de sempre.

Em especial aos amigos Angélica, Cassio, Luciana, Mariana e Ana Carolina pelos risos, desabafos, desafios e reflexões sobre os processos de construção teórica e metodológica dos nossos trabalhos acadêmicos. 
“(..) O que sobra na escrita é o que estava na fala." Luiz Antônio Marcuschi 


\section{RESUMO}

Este trabalho é sobre a importância da oralidade enquanto gênero discursivo-textual para o ensino de Geografia na Educação Básica e sua relação com a leitura e a escrita. A problematização emergiu no contexto de nossa participação no Círculo de Pesquisa e Estudos das Fronteiras Teóricas para a Formação de Professores de Geografia, ligado ao LEMADI - Laboratório de Ensino e Material Didático - Departamento de Geografia, USP, coordenado pela Prof. ${ }^{a}$ Dr $^{a}$ Maria Eliza Miranda e das investigações, reflexões e análises do nosso trabalho como professora na Rede Municipal de Ensino de São Paulo. O Ensino de Geografia não tem sido pensado a partir da centralidade da fala do aluno o que exige considerarmos a sua relação com a leitura e a escrita, por meio de interfaces e aproximações de fronteiras teóricas diversas, como a Teoria da Experiência de Aprendizagem Mediada, da Psicologia da Aprendizagem, da Linguística, da Filosofia da Linguagem e do paradigma da complexidade para uma compreensão para além dos aspectos comunicacionais, que contemple a aquisição de instrumentos psicológicos superiores mediados pela fala e, consequentemente o desenvolvimento de pensamentos por conceitos e a formação discursiva do aluno enquanto sujeito. Ainda que discussões de aspectos ligados ao processo de aprendizagem e uso da língua, como a importância da oralidade, sejam inicialmente desconhecidas por professores de Geografia, julgamos que sejam necessárias, pois se constituem como a plataforma mais efetiva de ensino e aprendizagem da própria Ciência, ao favorecer o desenvolvimento de níveis mais elevados de pensamento abstrato. Entretanto ao longo de nossa investigação e prática docente nos deparamos com lacunas e fragilidades de aspectos do processo de alfabetização que ainda persistem e acompanham alunos do Ensino Fundamental II, que estão relacionados diretamente com a oralidade. Diante dos resultados de avaliações externas sobre os níveis inadequados de proficiência dos alunos brasileiros podemos observar a implementação de programas e referenciais por meio de prescrições técnicas que oferecem aos professores poucos elementos de reflexão e ação para o enfrentamento do grave problema do analfabetismo escolar. Frente ao desafio de ensinar Geografia articulado ao desenvolvimento da oralidade concebida dentro de um contínuo com a leitura e a escrita buscamos por meio de uma perspectiva sociocultural de desenvolvimento humano novas análises que subsidiem prospecções de um ensino para além dos resultados de avaliações externas. Por conseguinte buscamos elaborar e aplicar conforme perspectiva encontrada em Schneuwly e Dolz (2010), a Sequência Didática de Geografia por gêneros discursivo-textuais "O Brasil vai de quê?", a qual envolveu 77 alunos do $7^{\circ}$ ano do Ensino Fundamental II de uma escola pública. Ao analisarmos o Debate Regrado presente na Sequência Didática que tinha como objetivo inicial incentivar o protagonismo dos alunos e o desenvolvimento de uma postura crítica frente aos fenômenos espaciais estudados avançamos para a compreensão dos turnos de Debate como textos orais dos alunos e que necessitam de mediação específica pelo professor para que se tornem possibilidades reais de processos de reorganização e expressão de enunciados e de conceitos, levando-os juntamente com a leitura e a escrita a pensar de maneira contextualizada e complexa.

Palavras-chave: oralidade, leitura e escrita, Ensino de Geografia, Sequência Didática, elaboração de conceitos. 


\begin{abstract}
This work is about the importance of orality as a discursive-textual genre for teaching Geography in Basic Education and its relationship with reading and writing. This problematization emerged in the context of our participation in the Circle of Research and Studies of Theoretical Borders Geography Teacher Training, attached to LEMADI Teaching Laboratory and Teaching Materials - Department of Geography, USP, coordinated by Prof. Dr. Maria Eliza Miranda and this is about investigations, reflections and analysis of our work as teachers in public schools of São Paulo city hall. The Geography Teaching has not been thought from the central speech of the student which requires consider their relationship with reading and writing, through interfaces and approaches of several theoretical frontiers, such as the Theory of Mediated Learning Experience, Psychology of Learning, Linguistics, Philosophy of Language and the complexity paradigm in order to an understanding beyond the communication aspects, covering the acquisition of higher psychological instruments mediated by talks and, consequently, the development of thinking by concepts and discursive formation of the student as a subject. Although discussions of issues linked to the learning process and use of language, as the importance of orality, they are initially unknown by geography teachers, we believe they are necessary, because they are the most effective platform for teaching and learning of Science itself, to promote the development of higher levels of abstract thinking. However throughout our research and teaching practice we are faced with gaps and weaknesses aspects of the alphabetization process that still persist and follow the students of the elementary school II, which are directly related to orality. Analyzing the results of external reviews of the inadequate levels of proficiency of Brazilian students we can observe the implementation of programs and references through technical requirements that give teachers a few elements of reflection and action to face the serious problem of school analphabetism. Face the challenge of teaching Geography articulated the development of orality conceived on a continuum with reading and writing, we search through a socio-cultural perspective of human development new analyzes that support surveys of teaching beyond the results of external evaluations. Therefore we search to develop and implement according the perspective found in Schneuwly and Dolz (2010), Geography Teaching Sequence by textual genres "O Brasil vai de quê?", which involved 77 students from the 7th grade of an elementary school II in a public school. Analyzing the discussion regimented presents in Teaching Sequence which had as initial objective to encourage the involvement of the students and development a critical attitude towards the space phenomena studied, we move to understanding the discussion shifts as oral texts of students who require specific mediation by the teacher to become real possibilities of a reorganization processes and statements of expression and concepts, bringing them together with reading and writing to think contextualized and complex way.
\end{abstract}

Keywords: orality, reading and writing, Geography Teaching, Teaching Sequence, development of concepts. 


\section{LISTA DE FIGURAS ${ }^{1}$}

Figura 1 - Representação das competências de leitura ................................................. 34

Figura 2 - Esquema da estrutura de sequência Didática por gênero discursivo textual . 62

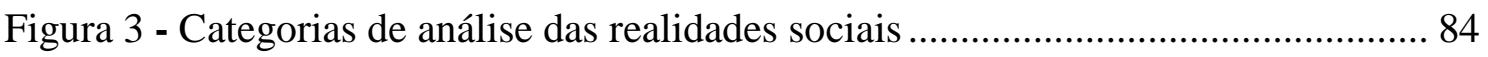

Figura 4 - Fotografia da folha de registro da organização dos grupos de trabalho do $7^{\circ}$

Ano B

Figura 5 - Fotografia dos registros elaborados pelos alunos e fixados na sala ambiente de Geografia.

Figura 6 - Fotografia do Flipchart exposto na entrada da sala ambiente de Geografia.

Figura 7 - Ativação cerebral causada por frases escritas.

Figura 8 - Principais mudanças induzidas pela aprendizagem da leitura e da escrita. . 123

Figura 9 - Modelo das operações textuais-discursivas do texto oral para o texto escrito.

Figura 10 - Alunos participantes do $2^{\circ}$ turno do Debate Regrado, $7^{\circ}$ Ano B, Novembro, 2013

Figura 11 - Alunos participantes do $2^{\circ}$ turno do Debate Regrado, $7^{\circ}$ Ano B, Novembro, 2013. 128

Figura 12 - Instrumento do Debate Regrado no contexto da SD "O Brasil vai de quê?"

Figura 13 - Flipchart preenchido com outras ilustrações e palavras exposto 144

Figura 14 - Lista de palavras apresentadas aos alunos durantes os turnos de DR da SD "O Brasil vai de quê?" 151

\footnotetext{
${ }^{1}$ Adotamos a designação de figura para todas as ilustrações constantes no texto desta dissertação, com exceção dos quadros e gráficos.
} 


\section{LISTA DE GRÁFICOS}

Gráfico 1 - Alunos frequentes e alunos com três produções textuais e participação do Debate Regrado.

Gráfico 2 - Número de alunos de cada uma das elaborações textuais escritas e oral ao longo da aplicação de SD.

Gráfico 3 - Proporção alunos participantes de todas as atividades da SD e alunos com atividades incompletas ou pendentes. 78

Gráfico 4 - Proporção de gêneros textuais escritos e orais planejados para a SD "O Brasil vai de quê?"

Gráfico 5 - Conceitos utilizados pelos alunos da amostra válida na elaboração textual intermediária.

Gráfico 6 - Conceitos utilizados pelos alunos da amostra válida na elaboração textual inicial.

Gráfico 7 - Conceitos utilizados pelos alunos da amostra válida na elaboração textual final.

Gráfico 8 - Contribuição da oralidade para a evolução do pensamento com leitura e escrita nas aulas de Geografia 120

Gráfico 9 - Alunos participantes do Debate Regrado da SD "O Brasil vai de quê?" ... 129

Gráfico 10 - Palavras-chave: Meios de Transporte - $7^{\circ}$ Ano B 149

Gráfico 11 - Palavras-chave: Rede de Transportes - $7^{\circ}$ Ano B 150

Gráfico 12 - Palavras-chave: Utilizações da Rede de Transportes - $7^{\circ}$ Ano B. 151

Gráfico 13 - Palavras-chave: Características e problemas da Rede de Transportes - $7^{\circ}$ Ano B

Gráfico 14 - Palavras-chave: Possíveis soluções e consequências para as Rede de Transportes 153 


\section{LISTA DE QUADROS}

Quadro 1 - Perspectiva dialógica da fala e da escrita.

Quadro 2 - Rol de habilidades a serem exploradas antes, durante e depois da leitura apresentadas no Referencial de expectativas para o desenvolvimento da competência leitora e escritora no ciclo II do ensino fundamental................................................. 38

Quadro 3 - Proposta de agrupamentos de gêneros discursivo-textuais 57

Quadro 4 - Caracterização geral das Sequências Didáticas de Geografia por gênero discursivo-textual, elaboradas e aplicadas em escola pública de Educação Básica ....... 71

Quadro 5 - Informações gerais sobre a Sequência Didática ........................................ 75

Quadro 6 - Gêneros discursivo-textuais na SD "O Brasil vai de quê" .......................... 89

Quadro 7 - Análise dos Domínios apresentados pelos alunos nas elaborações escritas.

Quadro 8 - Conceitos utilizados pelos alunos nas produções escritas e as respectivas siglas.

Quadro 9 - Trecho de elaboração textual com exemplo de conceito utilizado por aluno da turma A.

Quadro 10 - Trecho de elaboração textual com exemplo de conceito utilizado por aluno da turma B.

Quadro 11 - Trecho de elaboração textual com exemplo de conceito utilizado por aluno da turma C.

Quadro 12 - Exemplo I de turnos de falas dos alunos no Debate Regrado da SD "O Brasil vai de quê?"”.

Quadro 13 - Exemplo II de turnos de falas dos alunos no Debate Regrado da SD "O Brasil vai de quê?". 138

Quadro 14 - Entrecruzamento da oralidade, da leitura e da escrita na SD.

Quadro 15 - Exemplo III de turnos de falas dos alunos no Debate Regrado da SD “O Brasil vai de quê?".

Quadro 16 - Exemplo IV de turnos de falas dos alunos no Debate Regrado da SD "O Brasil vai de quê?". 156

Quadro 17 - Importância do Debate Regrado para o desenvolvimento das capacidades de linguagem dos alunos. 158 
Quadro 18 - Gêneros discursivo-textuais que apoiaram os alunos durante o Debate

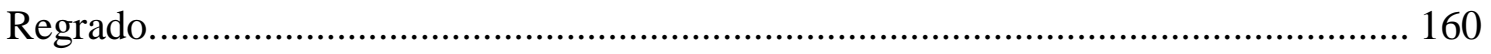

Quadro 19 - Análise da importância dos elementos do Debate Regrado para o texto escrito. 
ABREVIATURAS

EAM - Experiência de Aprendizagem Mediada

DR - Debate Regrado

FUND II - Ensino Fundamental II

LDB - Lei de Diretrizes e Bases da Educação Brasileira, nº 9394/96.

LEMADI - Laboratório de Ensino de Geografia e Material Didático

PCN - Parâmetros Curriculares Nacionais

SD - Sequência Didática

UNESCO - Organização das Nações Unidas para a Educação, a Ciência e a Cultura.

RT - Rede de transportes

TCLE - Termo de Consentimento Livre e Esclarecido 


\section{SUMÁRIO}

INTRODUÇÃO ...............................................................................................................18

Capítulo 1. Ler e escrever: compromisso de todas as áreas, mas como? ..........................27

1.1. Em busca de respostas para o desenvolvimento das competências leitora e escritora na aula de Geografia - Análise crítica do Referencial de expectativas para o desenvolvimento da competência leitora e escritora no ciclo II do Ensino Fundamental

1.2. O desdobramento da análise crítica: Caderno de Orientações Didáticas de Geografia

Capítulo 2. Uma sequência didática por gênero discursivo oral: a construção teórico-metodológica do problema de ensinar e aprender Geografia considerando a leitura e a escrita

2.1. A oralidade como gênero discursivo-textual: possibilidades e contribuições para pensar o ensino de Geografia.....

2.2. A oralidade como elemento para a formação de sujeitos na aula de Geografia

Capítulo 3. Da oralidade com o pensamento espontâneo à oralidade com a leitura e a escrita: o desafio da oralidade como gênero discursivo-textual na aula de Geografia

3.1. "O Brasil vai de quê?": os caminhos da Sequência Didática pelos módulos de atividades

3.2. Conceitos e traços da oralidade no texto escrito dos alunos.

3.3. A contribuição do gênero discursivo oral para a evolução do pensamento com leitura e escrita nas aulas de Geografia.

Capítulo 4. A aprendizagem mediada do Debate Regrado na aula de Geografia: o desafio de ensinar a oralidade na ação

4.1. O necessário entrecruzamento da oralidade, da leitura e da escrita na sequência didática por gênero discursivo oral

4.2. Novos conceitos e palavras chaves do Debate Regrado na escrita

4.3. As capacidades de linguagem dos alunos e o Debate Regrado

4.4. Articulação de diferentes gêneros textuais pelos alunos no Debate Regrado e no texto escrito 
Apêndice A - Termo de Consentimento Livre e Esclarecido - TCLE

Apêndice B - ANÁLISE DO REFERENCIAL DE EXPECTATIVAS PARA O DESENVOLVIMENTO DA COMPETÊNCIA LEITORA E ESCRITORA NO CICLO II: CADERNO DE ORIENTAÇÕES DIDÁTICAS DE GEOGRAFIA

Apêndice C - ANÁLISE DO REFERENCIAL DE EXPECTATIVAS PARA O DESENVOLVIMENTO DA COMPETÊNCIA LEITORA E ESCRITORA NO CICLO II: CADERNO DE ORIENTAÇÕES DIDÁTICAS DE GEOGRAFIA

ANEXO 1 - QUADRO EXPLICATIVO DOS SINAIS UTILIZADOS NAS

TRANSCRIÇÕES 


\section{INTRODUÇÃO}

"Oi; professora "tô" muito nervosa, em relação ao debate. Eu sou muito tímida e não gosto de falar em voz alta. Não sei o que fazer. "Tô" com muito medo". (Aluna 54, 2011) ${ }^{2}$

O relato da aluna diante da proposta de Debate Regrado na aula de Geografia, no contexto de aplicação de uma Sequência Didática, nos apresenta indícios acerca da importância do desenvolvimento da linguagem verbal oral ${ }^{3}$ na Educação Básica e a necessidade de pesquisas que contemplem dimensões relacionadas à oralidade, como a comunicação, a formação de sujeitos e a estruturação das formas de pensamento e do próprio conhecimento, questões tão caras ao ensino de uma maneira geral.

Sem dúvidas, a fala dos alunos, está presente no interior das escolas como elemento vivo das interações comunicativas cotidianas e imediatas por meio das inúmeras situações conversacionais que surgem entre os próprios alunos, com os professores e demais funcionários; entretanto, se encontramos alunos, como este que nos escreveu a mensagem, amedrontados diante da realização de uma atividade oral planejada torna-se, então, imprescindível trazer à tona o problema para o Ensino de Geografia.

Sem desprezarmos os aspectos psicossociais relacionados às situações que envolvem algum tipo de exposição oral para diferentes públicos, como a ansiedade, o nervosismo e a própria personalidade da aluna, que se diz tímida, é possível identificar, que a oralidade, enquanto atividade planejada de ensino, de uma maneira geral foi ignorada, esquecida ou propositalmente deixada em segundo plano das atividades escolares, submetendo muitos alunos da Educação Básica a anos de escolarização sem a experiência do exercício planejado da fala.

\footnotetext{
${ }^{2}$ Mensagem recebida por Rede Social, enviada por aluna da $8^{\mathrm{a}}$ série $/ 9^{\circ}$ ano em 21 de novembro 2011 por ocasião da atividade de Debate Regrado como parte da aplicação de Sequência Didática de Geografia por gêneros discursivos textuais em Escola Municipal de São Paulo (SP). Esta mensagem compõe o acervo empírico de nossa pesquisa.

${ }^{3}$ Durante o nosso trabalho transitamos entre os conceitos de "linguagem verbal oral", "fala" e "oralidade" que de acordo com o contexto será detalhado a qual nos referimos. Neste caso iniciamos nosso texto utilizando a linguagem verbal oral como o sistema de signos, que empregamos nas relações sociais por meio do uso das palavras, por compreendermos que a Geografia enquanto disciplina do currículo escolar pode, por meio do trabalho com os significados das palavras próprias da Ciência apoiar os alunos na elaboração de conceitos. Encontramos em Vigotski (2010) as explicações de tais conceitos, sobretudo nos artigos "As raízes genéticas do pensamento e da linguagem" (VIGOTSKI, 2010, p.111-150) e "Estudo experimental do desenvolvimento dos conceitos" (VIGOTSKI, 2010, p151-239).
} 
Refletindo sobre as causas e os possíveis impactos da ausência da participação oral dos alunos nas aulas, encontramos em Calkins ${ }^{4}$ (2002, p.125-126) pesquisas que datam da década de 1980, sobre o espaço de tempo das aulas destinado à leitura e à escrita. As pesquisas apontam que os alunos adolescentes norte-americanos, com turnos de sete horas nas escolas, ficam em média $80 \%$ da aula sentados passivamente, escutando o que o professor diz, completando ditados, copiando e memorizando definições, fazendo exercícios orientados, respondendo questões sobre a interpretação dada pelos professores de excertos de textos que leram ou escutaram.

Ainda que as pesquisas apresentadas por Calkins não tratem diretamente da temática sobre a importância da oralidade para o ensino elas nos oferecem elementos do ponto de vista quantitativo para pensarmos sobre os espaços e tempos da aula que são destinados para que os alunos participem oralmente, bem como as necessidades específicas que a atividade exige, como o planejamento da fala, estudos de conteúdos e informações que estarão em pauta e a mediação que os professores têm que realizar para que tais participações ocorram.

Na mesma década de 1980, encontramos em $\operatorname{Tragtenberg}^{5}$ (2012, p.123), no prefácio do livro de Paoli ${ }^{6}$ (1980), porém se referindo ao período histórico brasileiro, da década de 1960, referências à escola como um dos aparelhos de hegemonia dos setores dominantes da sociedade, que de acordo com o autor, operava em relação ao povo não pelo "fazer falar", mas pelo "fazer calar".

A expressão "fazer calar" que Tragtenberg utiliza para a escola no contexto do Regime Ditatorial no Brasil (1964-1985) reflete a imposição do silêncio como instrumento de repressão da fala, que compartilhada com outros sujeitos, por meio de enunciados, compõe uma das formas de desenvolvimento de novos modos de pensar acerca da realidade vivida.

Alguns dos efeitos da repressão pela imposição do silêncio na sociedade ainda podem ser percebidos por meio da identificação de práticas educativas que permanecem

\footnotetext{
${ }^{4}$ CALKINS, Lucy McCormick. A Arte de ensinar a escrever: o desenvolvimento do discurso escrito. Porto Alegre: Artes Médicas, 2002. Diante da escassez de referências e pesquisas relacionadas aos desafios que professores de diferentes disciplinas encontram em relação aos processos específicos de aprendizagem e uso da língua pelos alunos adolescentes do Ensino Fundamental II, Calkins destina o capítulo 11 de seu livro, denominado "O início da adolescência: o melhor período, o pior período", da seção II "Como os alunos mudam como escritores".

${ }^{5}$ TRAGTENBERG, Maurício. As condições de produção da educação. In: Educação e burocracia. São Paulo: 2012. Cap. 5, p. 261-265.

${ }^{6}$ PAOLI, Nuvenius Junqueira. Ideologia e hegemonia: as condições de produção da educação. São Paulo: Cortez, 1980.
} 
ao longo do tempo, como um ensino centrado na fala do professor, pautado, sobretudo na memorização, na reprodução ou na falta de sentido, de um conhecimento pronto e acabado, e que não respondem mais as demandas das atuais gerações.

Considerando o rápido avanço das mudanças no atual contexto do meio técnicocientífico-informacional e comunicacional ${ }^{7}$, proporcionados, sobretudo, pela telefonia móvel, que por meio dos smartphones acompanha e caracteriza muitos dos comportamentos das atuais gerações, é possível observar diversas mudanças, principalmente ligadas ao aspecto comunicacional da fala.

A conexão instantânea a um número ilimitado de informações e de amigos modificou a maneira como os adolescentes se relacionam e compreendem a própria realidade em que vivem e por consequente as estruturas de organização do pensamento.

Bauman (2011, p. 47), considerou o atual processo de avanços tecnológicos comunicacionais como uma fase de "grande revolução na conectividade humana", ao mesmo tempo em que os celulares são chamados pelo autor como "trincheiras" para a comunicação humana; uma vez que o paradoxo é o da possibilidade de conexão com pessoas e informações de distantes e diferentes espaços e ao mesmo tempo o distanciamento de pessoas e acontecimentos que estão muito próximos.

No entrecruzamento de diferentes ideias sobre a escola por meio da descrição das pesquisas apresentada por Calkins realizadas na década 1980, como a escassez de atividades que exijam a expressão oral dos alunos; da escola da década de 1960 que Tragtenberg chamou do "fazer calar"; da atual revolução na conectividade humana, com suas inúmeras possibilidades e limites como aponta Bauman; bem como a mensagem da aluna que introduz nosso texto, explicitam aspectos relacionados à participação ativa dos alunos por meio da oralidade ausentes na escola e que emergem diante das exigências das transformações da sociedade.

Autores como Marcuschi (1997), Schneuwly e Dolz (2010), todos ligados ao ensino de língua, admitem a escassez de pesquisas relacionadas à importância da oralidade para a formação comunicativa dos alunos, bem como o espaço limitado que ela tem nas aulas, em geral.

\footnotetext{
7 "O meio técnico-científico-informacional é a aparência geográfica da globalização". (SANTOS, 2002, p. 239) Ao conceito encontrado em Milton Santos, incluímos "comunicacional" devido ao atual contexto de avanços tecnológicos, sobretudo no campo da comunicação humana, possibilitada sobretudo pela telefonia móvel. SANTOS, M. A Natureza do Espaço - Técnica e Tempo, Razão e Emoção. 5 ed. São Paulo: Edusp, 2002
} 
O Ensino de Geografia não tem sido pensado a partir da centralidade da fala do aluno o que exige considerarmos interfaces e aproximações de campos teóricos e metodológicos diversos, para além das fronteiras que a especialização das disciplinas do currículo escolar nos impõe, para uma perspectiva mais ampliada da elaboração do conhecimento e da formação do sujeito na escola.

Foucambert (2002, p.35) ao focalizar em seu trabalho a importância da leitura na formação dos alunos, considera as especificidades das disciplinas escolares, sendo a Geografia uma delas, porém nos apoia quando destaca a linguagem verbal como aspecto comum do trabalho educativo:

[...] cada professor é agente de um campo próprio, mas cuja especificidade se delimita a partir de uma plataforma comum, cujos pressupostos e técnicas ele deve compartilhar com todos os coeducadores que atuam antes, depois e no momento da sua própria intervenção. Apresenta aquilo que ele não deve tampouco ignorar se considerar que sua intervenção se torna mais eficaz em função da sua coerência e da sua complementaridade com o conjunto do sistema escolar e de sua relação com as motivações e com o universo de leituras de seus alunos.

A nosso ver, a linguagem verbal como plataforma comum que Foucambert se refere, diz respeito aos textos escritos e orais que estão presentes na base das aulas das diferentes disciplinas do currículo escolar como ferramentas primordiais para ensinar, por isso as discussões, bem como a compreensão de aspectos ligados ao processo de aprendizagem e uso da língua podem ser objetos de discussão, para além dos professores de Língua Portuguesa.

Em seu trabalho Nonnon $(1999 \text {, p. } 87)^{8}$ constata o deslocamento das atenções das pesquisas para a legitimação da leitura e escrita na escola e assim o pequeno espaço da oralidade na formação acadêmica e profissional, distanciando os professores do que denomina de uma cultura de aprendizagem comum.

Ainda que discussões de aspectos ligados ao processo de aprendizagem e uso da língua, como a importância da oralidade, sejam inicialmente desconhecidas por professores de Geografia, julgamos que seja a possibilidade mais efetiva de ensino e

\footnotetext{
${ }^{8}$ No original: "Elle n'est pourtant jamais parvenue à se légitimer sur le plan didactique et à stabiliser des orientations opératoires et consensuelles; cette question qui touche pourtant le quotidien du métier a peu de place dans les formations universitaires et professionnelles et les enseignants ne disposent pas sur ce point de savoirs de référence constituant l'amorce d'une culture didactique commune. Malgré ces affirmations de principe, sous-tendues à la fois par un effet d'évidence et des tensions fortes non explicitées, la place de l'oral et son apprentissage ont été occultés pendant des années. Le peu d'études consacrées précisément à l'oral ont rencontré peu d'écho: le décalage avec les travaux didactiques sur la lecture et l'écriture est flagrant, comme le soulignait Ropé en 1990 (de 1980 à 1990 les recherches sur l'oral sont passées de $25 \%$ à $10 \%$ des recherches en didactique du français) ". (NONNON, 1999, p.87)
} 
aprendizagem da própria Ciência; a saber, pesquisas dos campos da Psicologia e da própria Linguística apontam que, atividades como o Debate Regrado e a Exposição Oral, por exemplo, vão muito além, no que diz respeito à comunicação, e contemplam a aquisição de instrumentos psicológicos superiores mediados pela fala; e, consequentemente o desenvolvimento de pensamentos por conceitos e a formação discursiva do aluno enquanto sujeito.

O Ensino de Geografia, considerando aspectos da abordagem cultural da própria ciência geográfica que destaca no conjunto de suas investigações a importância das representações que os sujeitos do espaço constroem ao longo de sua existência, tem como papel, enquanto disciplina na escola, contribuir para o processo de elaboração da visão de mundo de crianças e adolescentes na idade escolar, que segundo Claval (2013, p.144):

Constitui uma das abordagens possíveis para perceber, compreender e explicar o mundo, a natureza, a sociedade e o homem; é um conjunto de conhecimentos e de técnicas que permitem transformar a natureza, modelar o ambiente e influenciar o funcionamento e o futuro dos grupos sociais.

Sabendo-se das representações de mundo que os alunos constroem ao longo da escolarização, e assim a importância que a própria Geografia tem a oferecer para esta construção, que ocorre pela interação humana por intermédio da linguagem verbal é que julgamos imprescindível desde a proposta inicial desta pesquisa compreender a importância da oralidade nas aulas considerando também os conflitos e as contradições que o professor tem que enfrentar para que o aluno aprenda enunciados acadêmicos e científicos necessários para a aprendizagem de Geografia e desenvolva simultaneamente níveis cada vez mais altos de pensamento abstrato e complexo.

Centralizamos nossa atenção na complexidade da tarefa de garantir o desenvolvimento da oralidade, bem como da leitura e da escrita na aula de Geografia na Educação Básica, compreendendo-os como processos imbricados e fundamentais para a formação de sujeitos.

Apoiamo-nos na proposta da organização do Ensino em Sequências Didáticas (SD) por gêneros discursivo-textuais como possibilidade de recobrir as demandas da tarefa, articulando as especificidades do ensino da ciência geográfica, da elaboração de conceitos e o processo de aprendizagem e uso da língua, com foco na formação discursiva. 
Considerando os desafios, principalmente, que dizem respeito ao Ensino de Geografia e ao aluno, em uma perspectiva que transcende o momento imediato dos objetivos e das relações que ocorrem na escola, o foco de análise deste estudo se construiu com a seguinte questão: “Qual a importância da oralidade para o processo de elaboração de conceitos pelos alunos no contexto de aplicação de uma Sequência Didática de Geografia por gêneros discursivo-textuais em turmas de $7^{\circ}$ anos do Ensino Fundamental da escola pública?".

Ao delimitarmos o foco de análise da nossa pesquisa na importância da oralidade para o processo de elaboração de conceitos pelos alunos nos deparamos com a relação dialógica em que se inscrevem fala e escrita e como estão presentes na escola:

\begin{abstract}
Não se pode tratar as relações entre (...) fala e escrita de maneira estanque e dicotômica. A proposta é a de que se vejam essas relações dentro de um quadro mais amplo no contexto das práticas comunicativas e dos gêneros textuais. A sugestão segue uma visão funcional e preserva um contínuo de variações, gradações e interconexões, a depender do que se compara. Em certos casos, as proximidades entre fala e escrita são tão estreitas que parece haver uma mescla, quase uma fusão de ambas, numa sobreposição bastante grande tanto nas estratégias textuais como nos contextos de realização. Em outros, a distância é mais marcada, mas não a ponto de ter dois sistemas linguísticos ou duas línguas, como se disse por muito tempo. Uma vez concebida dentro de um quadro de inter-relações, sobreposições, gradações e mesclas, as relações entre fala e escrita recebem um tratamento mais adequado, permitindo aos usuários da língua maior conforto em suas atividades discursivas. (MARCUSCHI, 2001, p.10)
\end{abstract}

Passamos a considerar em nossa análise o sentido que Marcuschi explica acerca da existência de inter-relações entre a fala e a escrita no contexto das práticas comunicativas e dos gêneros textuais o que nos apontou para questões relacionadas ao processo de alfabetização uma vez que identificamos na prática de nossas aulas, alunos do Ensino Fundamental II que não são capazes de ler e escrever com autonomia refletindo diretamente na oralidade, foco de nossa investigação.

Os resultados de proficiência apresentados por alunos brasileiros em testes, como a avaliação internacional de competência de leitura, promovida pela Organização para Cooperação e Desenvolvimento Econômico, intitulada PISA (OECD, 2002) colocam o Brasil em último lugar dentre 32 países.

O relatório final do Grupo de trabalho alfabetização infantil da Comissão de Educação e Cultura da Câmara dos Deputados (2007) aponta que quase 80\% dos alunos que concluem o Ensino Fundamental se tornam candidatos a analfabetos funcionais, que 
de acordo com a UNESCO ${ }^{9}$ é toda pessoa que sabe escrever seu próprio nome, ler e escrever frases simples, realizar cálculos básicos, contudo, é incapaz de usar a leitura e a escrita em atividades rotineiras do dia a dia, principalmente no que diz respeito à compreensão de diferentes textos (INFANTE, 1994, p.224), considerando a sociedade altamente letrada ${ }^{10}$ que vivemos.

O contexto de um desempenho de proficiência inadequado dos alunos brasileiros da Educação Básica contribuiu para que viesse à tona a difusão da ideia da responsabilidade de todas as áreas do currículo escolar para o desenvolvimento das competências leitora e escritora, e por ser tão complexa e desafiante, principalmente para os professores do Ensino Fundamental II, que de uma maneira geral não dominam aspectos do processo de aprendizagem e uso da língua, principalmente frente à precariedade da decodificação de símbolos, interpretação e compreensão da leitura e a produção de textos pelos alunos.

Aspectos estes da alfabetização, relacionados diretamente a oralidade, tornam-se imprescindíveis na nossa abordagem, uma vez que a leitura e a escrita de diversos gêneros textuais são fundamentais para o aprendizado dos conteúdos próprios das diferentes disciplinas do currículo escolar, para a elaboração de $\operatorname{conceitos}^{11}$ e a formação discursiva ${ }^{12}$ dos alunos desta etapa da escolarização.

Organizamos nossa pesquisa em quatro capítulos, sendo o primeiro denominado "Ler e escrever: compromisso de todas as áreas, mas como?", discutimos em que medida os resultados das avaliações externas sobre os níveis de proficiência dos alunos brasileiros colaboram para a difusão da ideia de que a responsabilidade do desenvolvimento das competências leitora e escritora deve ser de todas as disciplinas do currículo escolar, porém sem considerar que os professores do Ensino Fundamental II, de uma maneira geral, desconhecem aspectos importantes do processo de alfabetização e por conseguinte da oralidade dos alunos nesta fase da escolarização.

\footnotetext{
${ }^{9}$ Conceito definido na Conferência Geral da UNESCO em 1978.

${ }^{10}$ Utilizamos o termo letramento para nomear fenômenos distintos daquele denominado alfabetização. Acompanhamos Magda Soares (2004) quando afirma que há uma especificidade e, ao mesmo tempo, a indissociabilidade dos processos de alfabetização e letramento. Sendo que letramento está relacionado, a necessidade de reconhecer e nomear práticas sociais de leitura e de escrita mais avançadas e complexas que as práticas do ler e do escrever resultantes da aprendizagem do sistema de escrita e portanto de alfabetização.

${ }^{11}$ Utilizamos as pesquisas e estudos experimentais de Vigotski (2010) para a compreensão dos processos de elaboração de conceitos como forma de pensamentos caracterizados por altos níveis de abstrações e generalizações.

${ }_{12}$ Para Bakhtin $(2010$, p. 274) “(...) o discurso só pode existir de fato na forma de enunciações concretas de determinados falantes, sujeitos do discurso. $\mathrm{O}$ discurso sempre está fundido em forma de enunciado pertencente a um determinado sujeito de discurso, e fora dessa forma não pode existir".
} 
$\mathrm{Na}$ esfera da rede de ensino municipal de São Paulo encontramos dois documentos que representam a resposta das políticas públicas educacionais para as lacunas e fragilidades de aspectos do processo de alfabetização apresentados pelos alunos do Ensino Fundamental II. Julgamos relevante, como parte da discussão, realizar a análise crítica dos documentos: Referencial de expectativas para o desenvolvimento da competência leitora e escritora no ciclo II do Ensino Fundamental (2006) ${ }^{13}$ e Caderno de Orientações Didáticas para o ensino de Geografia (2006) ${ }^{14}$. Tais documentos se inserem no contexto de um conjunto de subsídios técnicos e prescritivos para os professores aplicarem juntamente aos alunos, como se isso fosse suficiente para a formação e responsabilização dos professores de todas as áreas do currículo escolar acerca dos aspectos do complexo processo de alfabetização.

No capítulo 2: "Uma sequência didática por gêneros discursivo oral: a construção teórico-metodológica do problema de ensinar e aprender Geografia considerando a leitura e a escrita", apresentamos as possibilidades e contribuições do texto oral para o Ensino de Geografia por meio do plano material de nossa pesquisa que foi emergindo e organizado durante a aplicação de SD, ao longo das aulas de Geografia, que foram acompanhadas de reflexões teórico-metodológicas que apontaram a necessidade de se pesquisar a importância da oralidade para o ensino e aprendizagem de Geografia e, ao mesmo tempo, configurar uma qualidade maior ao processo escolar ao focalizar também a formação de sujeitos, considerando-se a necessidade e o potencial que alunos do Ensino Fundamental II apresentam no sentido de participar ativamente das aulas, questão importante para a Educação, para a própria Geografia, para a sociedade e para a cultura.

A Sequência Didática que aplicamos foi elaborada no contexto dos estudos e pesquisas que se realizam no LEMADI - Laboratório de Ensino de Geografia e Material Didático sob a orientação e coordenação da Prof. ${ }^{a}$ Dr $^{a}$ Maria Eliza Miranda, que envolve diversas abordagens temáticas sobre o ensino e aprendizagem de Geografia e a formação de professores de Geografia, com trabalhos e enfoques envolvendo diferentes concepções que foram denominadas por Miranda (2010) de "fronteiras teóricas para a

13 SÃO PAULO (Cidade). Secretaria Municipal de Educação. Diretoria de Orientação Técnica. Referencial de expectativas para o desenvolvimento da competência leitora e escritora no ciclo II do ensino fundamental /São Paulo: SME/DOT 2006.

14 SÃO PAUlO (Cidade). Secretaria Municipal de Educação. Diretoria de Orientação Técnica. Referencial de expectativas para o desenvolvimento da competência leitora e escritora no ciclo II: caderno de orientação didática de Geografia / Secretaria Municipal de Educação - São Paulo: SME / DOT, 2006. 68 p. 
formação de professores", numa perspectiva metodológica que busca interfaces e aproximações entre diversos sistemas teóricos. As fronteiras teóricas permeiam e fundamentam assim os caminhos por nós aqui adotados de elaboração e aplicação de Sequências Didáticas no ensino de Geografia objetivando formar sujeitos no âmbito da Educação Básica.

Tendo em vista os referenciais teóricos da Experiência de Aprendizagem Mediada, da Filosofia da Linguagem e do pensamento complexo de Edgar Morin no contexto do desenvolvimento das competências leitora e escritora é que o planejamento e aplicação da Sequência Didática "O Brasil vai de quê?" por gêneros discursivotextuais ocorreu em nossas aulas de Geografia na Escola Municipal de Ensino Fundamental General Alcides Gonçalves Etchegoyen, localizada no Jardim Arpoador, zona oeste da cidade de São Paulo, entre os meses de agosto e dezembro de 2013, em três turmas de $7^{\circ}$ anos $(\mathrm{A}, \mathrm{B}, \mathrm{C})^{15}$, envolvendo 77 alunos ${ }^{16}$.

No capítulo 3: "Da oralidade com o pensamento espontâneo à oralidade com a leitura e a escrita: o desafio da oralidade como gênero discursivo-textual na aula de Geografia" apresentamos a lógica que estruturou os módulos de atividades de nossa SD e as análises que realizamos focalizando os traços de oralidade presente nos textos escritos dos alunos.

No capítulo 4: “A aprendizagem mediada do Debate Regrado na aula de Geografia: o desafio de ensinar a oralidade na ação" focalizamos nossa análise na importância e contribuições do Debate Regrado como gênero discursivo-textual da modalidade oral e no entrecruzamento entre os textos escritos dos alunos no contexto de aplicação da Sequência Didática "O Brasil vai de quê?” para o desenvolvimento de pensamentos por conceitos e a aprendizagem de Geografia.

Nas considerações finais retomamos a problematização inicial, confrontamos com as análises realizadas, sobretudo do plano empírico desta pesquisa e prospectamos novas possibilidades para o Ensino de Geografia articulando a oralidade no entrecruzamento da leitura e da escrita para a formação de sujeitos na Educação Básica.

\footnotetext{
${ }^{15}$ Em 2013 as turmas ainda estavam organizadas em séries, por este motivo, há documentos que aparecem $6^{\mathrm{a}}$ séries como referência às turmas que participaram da aplicação de Sequência Didática. No corpo do texto optamos por utilizar a atual denominação e por isso adotamos $7^{\circ}$ anos.

${ }^{16}$ Os Termos de Consentimento Livre e Esclarecido (TCLE) assinados pelos responsáveis dos alunos participantes compõem o acervo de nossa pesquisa por conterem dados que devem ser preservados e mantidos em sigilo. No Apêndice A consta uma cópia do TCLE utilizado por nós.
} 


\section{Capítulo 1. Ler e escrever: compromisso de todas as áreas, mas como?}

Ao resgatarmos o título do livro organizado por Iara Neves da década de 1990: Ler e escrever: compromisso de todas as áreas ${ }^{17}$ encontramos nesta proposição inicial por meio da leitura e da escrita uma possibilidade para a Geografia, enquanto disciplina escolar, participar das discussões sobre a importância da oralidade na elaboração de conceitos pelos alunos do Ensino Fundamental II.

Destacamos que nossa pesquisa parte da perspectiva do Ensino de Geografia na Educação Básica na escola pública em que a oralidade, a leitura e a escrita são compreendidas como fenômenos interdependentes, ainda que com características próprias, estão diretamente relacionados não somente pelos aspectos do código da nossa língua, mas principalmente pelos aspectos culturais e das práticas sociais.

Marcuschi (2012, p.15) na introdução do seu livro inseriu uma epígrafe do antropólogo Clifford Geertz (1999, p.11) que julgamos muito adequada para a proposta de articular o ensino de Geografia às potencialidades do desenvolvimento da oralidade na sala de aula relacionadas à leitura e à escrita: "aquilo que se vê depende do lugar em que foi visto, e das outras coisas que foram vistas ao mesmo tempo".

Neste sentido compreendemos que enquanto docente ${ }^{18}$, as aulas de Geografia que lecionamos constituem-se como "o lugar de onde vemos" ocorrer o fenômeno da oralidade, da leitura e da escrita por meio das interações sociais, comunicativas e da circulação do conhecimento entre os alunos e nós; e "as outras coisas que vemos ao mesmo tempo" a que Geertz se refere, dizem respeito às interfaces e aproximações com outras fronteiras teóricas ${ }^{19}$ que não só a Geografia e que realizamos durante esta pesquisa.

Entre "as outras coisas que vemos ao mesmo tempo" (GEERTZ, 1999, p.11) destacamos quatro diferentes perspectivas de análise para a fala e a escrita no ensino escolar, entre elas aquelas que reconhecem apenas as dicotomias entre as duas modalidades dando origem segundo Marcuschi (2001, p. 28) à maioria das gramáticas

\footnotetext{
${ }^{17}$ NEVES, Iara C. B. et alli.(Orgs.) Ler e escrever: compromisso de todas as áreas. Porto Alegre: Ed da Universidade/UFRGS, 1998

${ }^{18}$ Lecionamos Geografia no Ensino Fundamental II da Rede Municipal de Ensino de São Paulo desde 2008.

${ }^{19}$ Diferentes concepções que foram denominadas por Miranda (2010, p.11) de "fronteiras teóricas para a formação de professores", numa perspectiva metodológica que busca interfaces e aproximações entre diversos sistemas teóricos no contexto de uma pesquisa dialógica.
} 
pedagógicas que se acham hoje em uso. Esta visão privilegia os aspectos formais postulando a fala como de menor complexidade e a escrita de maior complexidade.

Uma segunda perspectiva de análise da fala e da escrita é a variacionista e se dedica a apontar as variações de usos da língua sem fazer distinções dicotômicas, porém submetendo-as a algum tipo de norma. Marcuschi (2001, p. 31) explica que “(...) como nem todas as normas podem ser padrão, uma ou outra delas será tida como norma padrão. A decisão é muito menos linguística do que ideológica (...)”. (Grifo do autor)

O dilema da perspectiva variacionista é considerar fala e escrita como dois dialetos, submetidos às variações linguísticas de ordem padrão e não-padrão no ensino, o que possibilitaria, por exemplo, o domínio do dialeto padrão na atividade escrita e continuar no dialeto não-padrão no desempenho oral (MARCUSCHI, 2001, p. 32).

A terceira perspectiva de análise da fala e da escrita é a tendência fenomenológica de caráter culturalista que segundo Marcuschi (2001, p. 28) consiste em análises sobretudo de cunho cognitivo, antropológico ou social e desenvolve uma fenomenologia da escrita e seus efeitos na forma de organização e produção de conhecimento.

Esta tendência fenomenológica de caráter culturalista se aproxima mais de uma perspectiva epistemológica desenvolvida por antropólogos, psicólogos e sociólogos em que se concebem as práticas da oralidade versus escrita, do que a observação dos fatos e usos da língua.

A quarta e última perspectiva chamada de dialógica ou sociointeracionista ${ }^{20}$, apresentada por Marcuschi (2001, p. 34) corresponde aos:

(...) processos de produção de sentido tomando-os sempre como situados em contexto sócio historicamente marcados por atividades de negociação ou por processos inferenciais. Não toma as categorias linguísticas como dadas a priori, mas como construídas interativamente e sensíveis aos fatos culturais. Preocupa-se com a análise dos gêneros textuais e seus usos em sociedade. Tem muita sensibilidade para fenômenos cognitivos e processos de textualização na oralidade e na escrita, que permitem a produção de coerência como uma atividade do leitor/ouvinte sobre o texto recebido.

Partindo da perspectiva dialógica que Marcuschi (2001) apresenta para o uso e inter-relações entre fala e escrita, articulada à proposição inicial do título do nosso capítulo, acreditamos que esta seja uma possibilidade para que professores de Geografia

\footnotetext{
${ }^{20}$ Adotamos neste trabalho como "perspectiva dialógica" de análise da fala e da escrita, ao contrário do autor Marcuschi que adota "perspectiva sociointeracionista" por considerarmos mais adequada no contexto dos referenciais teóricos adotados por nós, sobretudo, Bakhtin, Vigotski, Feuerstein e Morin.
} 
insiram-se mais ativamente nas discussões sobre o desenvolvimento da oralidade, da leitura e escrita, sem renunciar a temas, assuntos e conteúdos próprios da disciplina que lecionam na Educação Básica.

Os fundamentos centrais da perspectiva dialógica de análise da fala e da escrita e que permearam nosso trabalho foram sintetizados no quadro 1, referenciando por aproximações e interfaces com autores que apoiaram nosso referencial teórico.

Quadro 1 - Perspectiva dialógica da fala e da escrita.

\begin{tabular}{|l|}
\hline Perspectiva sociointeracionista \\
\hline Fala e escrita apresentam: \\
Dialogicidade \\
Usos estratégicos \\
Funções interacionais \\
Envolvimento \\
Negociação \\
Situacionalidade \\
Coerência \\
Dinamicidade
\end{tabular}

Fonte: MARCUSCHI, Luiz Antônio. Da fala para a escrita: Atividades de retextualização. São Paulo: Cortez, 2001. p.33.

Diante das diversas perspectivas de análise da fala e da escrita Marcuschi (2001, p. 33) como linguista, tem como proposta geral, a fusão da visão variacionista, com os postulados da Análise da Conversação etnográfica, aliados à Linguística de texto que constituem um caminho entre: “(...) correlações entre formas linguísticas (dimensão linguística), contextualidade (dimensão funcional), interação (dimensão interpessoal) e cognição no tratamento das semelhanças e diferenças entre fala e escrita nas atividades de formulação textual-discursiva". (MARCUSCHI 2001, p. 33)

A proposta geral de fusão das perspectivas de análise da fala e da escrita de Marcuschi (2001, p. 33) nos permite encontrar nas diferentes dimensões possíveis parâmetros que indiquem a importância da oralidade para a elaboração de conceitos nas aulas de Geografia, sobretudo de uma perspectiva dialógica em que ora as relações entre leitura e escrita são explícitas e ora há a prevalência das características próprias de cada uma das modalidades oral e escrita, sobretudo quando contextualizadas em gêneros textuais. 
Além disso, a proposta de fusão das perspectivas aponta aos demais professores, de diferentes áreas do currículo escolar, possibilidades de construção de sentidos para se aproximarem, mais precisamente de uma plataforma comum (FOUCAMBERT, 1997) do trabalho docente, ou seja, uso da língua, por meio dos gêneros textuais orais e escritos, e assim encontrar instrumentos de mediação dos alunos nas diversas compreensões acerca dos fenômenos estudados.

Com efeito, a aproximação entre a oralidade, a leitura e a escrita com a Geografia, enquanto disciplina do currículo escolar, poderia gerar inúmeras possibilidades de análise e desenvolvimento de quadros teóricos e metodológicos de ensino, porém esbarram em aspectos da alfabetização ausentes ou ainda muito fragilizados nos alunos, e que são imprescindíveis aos processos de aprendizagem nesta fase da escolarização como a decodificação de símbolos, interpretação e compreensão da leitura e a produção de textos.

Na perspectiva dialógica em que a concepção de fala e escrita estão imbricados, porém com característica próprias, podemos identificar mais claramente aspectos do conceito de letramento $^{21}$ do ponto de vista da função social, em que destacamos as contribuições de Magda Soares (2004) que ao longo de suas pesquisas afirma haver uma especificidade e, ao mesmo tempo, uma indissociabilidade da alfabetização e do letramento. Sendo que o letramento está relacionado à necessidade de reconhecer e nomear práticas sociais de leitura e de escrita mais avançadas e complexas que as práticas do ler e do escrever resultantes da aprendizagem do sistema de escrita e portanto de alfabetização.

Encontramos na escola pública da Rede Municipal de São Paulo onde lecionamos Geografia desde 2008, inúmeros casos de textos escritos pelos alunos do Ensino Fundamental II, que em geral, apresentam ideias desconexas, mal estruturadas e com indícios de uma alfabetização muito precária, o que nos levou por algum tempo a evitar atividades que exigiam elaborações textuais escritas.

Podemos afirmar que o mesmo ocorreu em relação às participações orais dos alunos que muitas vezes caracterizaram-se por palavras e frases inicialmente sem

\footnotetext{
${ }^{21}$ Neste trabalho distinguimos as diferenças entre os termos para nos referirmos aos dois processos, tanto da perspectiva sociointeracionista - o uso da língua, relacionada ao letramento; quanto da alfabetização aprendizagem do sistema de escrita e quando necessário articulamos em um só conceito adotando o seguinte termo: "aprendizagem e uso da língua" indicando as modalidades oral e/ou escrita a qual atribuímos, de acordo com o contexto.
} 
sentido ou muitas vezes resumidas apenas à leitura segmentada, em voz alta, de algum texto escrito.

Soares (2004, p. 25) atribui ao problema da alfabetização precária e frágil dos alunos brasileiros expressos em tantos resultados de avaliações e testes externos à escola, bem como observados em nossa prática docente no ensino Fundamental II da escola pública, como um problema da prevalência do conceito de letramento sobre o conceito de alfabetização, como explica a própria autora:

Enquanto nesses outros países (França e Estados Unidos) a discussão do letramento - illettrisme, literacy e illiteracy - se fez e se faz de forma independente em relação à discussão da alfabetização apprendre à lire et à écrire, reading instruction, emergent literacy, beginning literacy -, no Brasil a discussão do letramento surge sempre enraizada no conceito de alfabetização, o que tem levado, apesar da diferenciação sempre proposta na produção acadêmica, a uma inadequada e inconveniente fusão dos dois processos, com prevalência do conceito de letramento, (...) o que tem conduzido a um certo apagamento da alfabetização que, talvez com algum exagero, denomino desinvenção da alfabetização. (Grifo do autor)

Encontramos a mesma preocupação que Soares (2004) apresentou sobre a necessidade de um ensino específico do código alfabético para nossas crianças por meio da alfabetização, no relatório sobre alfabetização infantil que especialistas elaboraram, a pedido da Comissão de Educação e Cultura da Câmara dos Deputados (2007, p.57) ${ }^{22}$ apoiados em pesquisas realizadas em diversos países e chamam a atenção para:

A compreensão é o objetivo central da leitura. A compreensão não depende apenas da leitura e é independente dela: podemos compreender sem ler, da mesma forma que podemos ler sem compreender. Compreensão não é específica à leitura ou à pessoas alfabetizadas. A confusão entre o propósito da leitura e o processo de aprender a ler levou ao abandono de práticas eficazes de alfabetização e sua substituição por práticas que, em nome de promover a compreensão, podem prejudicar de forma irreversível a capacidade dos alunos lerem com autonomia.

No sentido de discutir sobre a ideia de responsabilizar os professores de todas as disciplinas pelo desenvolvimento das competências leitora e escritora como alternativa para o contexto de baixos resultados de proficiência apresentados por alunos brasileiros em testes, como a avaliação internacional de competência de leitura, promovida pela Organização para Cooperação e Desenvolvimento Econômico, intitulada PISA (OECD,

\footnotetext{
${ }^{22}$ BRASIL. Congresso Nacional. Câmara dos Deputados. Comissão de Educação e Cultura. Grupo de trabalho alfabetização infantil: os novos caminhos: relatório final. 2. ed. Brasília: Câmara dos Deputados, Coordenação de Publicações, 2007. p. 180.
} 
2000) em que o Brasil ficou em último lugar dentre os 32 países participantes, é que acrescentamos ao título do nosso capítulo, a pergunta "mas como?"

Dados do relatório final do Grupo de trabalho alfabetização infantil da Comissão de Educação e Cultura da Câmara dos Deputados (2007) reforçam o problema apontando que quase $80 \%$ dos alunos $^{23}$ que concluem o Ensino Fundamental se tornam candidatos a analfabetos funcionais, que de acordo com a $\mathrm{UNESCO}^{24}$ é toda pessoa que sabe escrever seu próprio nome, ler e escrever frases simples, realizar cálculos básicos, contudo, é incapaz de usar a leitura e a escrita em atividades rotineiras do dia a dia, principalmente no que diz respeito à compreensão de diferentes textos (INFANTE, 1994, p.224), considerando a sociedade altamente letrada que vivemos.

Na década de 1980 os trabalhos de Molina (1992, p.6) sobre a importância da leitura e o papel da escola na formação do leitor já indicavam a importância do ensino da leitura para a aprendizagem e a necessidade de envolvimento dos professores de todas as áreas do currículo escolar para a formação dos jovens brasileiros: "A leitura é fundamental para a aprendizagem de todos os conteúdos escolares e os cuidados com o seu ensino devem ser responsabilidade dos professores de todas as áreas, não apenas do professor de língua materna".

Após o amplo período de democratização do acesso ao ensino entre as décadas de 1960 a 1980 com a ampliação da oferta do número de matrículas, a formulação e difusão da ideia de responsabilização dos professores pela competência leitora e escritora dos alunos se intensificou na década de 1990 em que o desafio educacional passa a ser a qualidade da escolarização oferecida à população.

Parte da qualidade da educação consiste na busca de uma solução para o problema do analfabetismo, que ultrapassa os limites da escola e alcança as várias esferas social, cultural, econômica e científico do nosso país que requerem a leitura e a escrita como parte da formação de sujeitos envolvidos na construção e desenvolvimento de diversos campos de ação.

Sem a pretensão de fazer uma análise profunda dos efeitos do analfabetismo escolar para a nossa sociedade ao acrescentarmos à proposição principal do título deste capítulo a pergunta "mas como?" focalizamos o quão desafiadora, para os professores do Ensino Fundamental II, e em especial, os professores de Geografia, é a tarefa de

\footnotetext{
${ }^{23}$ A informação sobre a porcentagem de alunos concluintes do Ensino Fundamental e que são candidatos a se tornarem analfabetos funcionais foi obtida por meio da análise de dados do SAEB - Sistema de Avaliação da Educação Básica.

${ }^{24}$ Conceito definido na Conferência Geral da UNESCO em 1978.
} 
ensinar a disciplina escolar e, simultaneamente, serem responsáveis por colocar em prática aspectos que envolvem o aprendizado e uso da língua, que de uma maneira geral, não dominam.

Juntamente com a difusão da ideia de responsabilização dos professores pelo desenvolvimento das competências leitora e escritora de seus alunos há outras premissas que implicitamente amparam a ideia principal e julgamos relevante para nossa análise explicitar. Sendo a primeira, de que os professores deveriam dominar a sua própria língua, bem como os gêneros textuais, ao menos aqueles que são próprios da sua disciplina e, por conseguinte, desenvolver em suas aulas as competências leitora e escritora de seus alunos.

Esta premissa amparou uma série de orientações apenas prescritivas aos professores como se não fossem necessários conhecimentos anteriores e específicos para o trabalho didático com a leitura e a escrita, e menos ainda com a oralidade, uma vez que os alunos já chegam à escola falando.

Convém, portanto destacar que para o professor de Geografia poder assumir a condução de ensino de um objeto frente a vários alunos exige uma formação consistente sobre os processos de aprendizagem e conhecimentos ampliados e aprofundados sobre o que se pretende ensinar e que conhecimentos elementares relacionados com a prática não são suficientes para a mediação de funções intelectuais mais elaboradas e complexas com elevados níveis de abstração.

Visto a necessidade de conhecimentos específicos, temos a licenciatura em Letras em que os professores de Língua Portuguesa são formados para o trabalho específico com a língua com os alunos do Ensino Fundamental II e Médio, e há ainda a formação que professores do Ensino Fundamental I buscam em geral, em cursos de Pedagogia, sobre os aspectos da alfabetização.

A alfabetização é composta por uma série de competências e habilidades, como consciência fonológica, consciência fonêmica, conhecimento do princípio alfabético, decodificação, fluência, estratégia de compreensão de textos entre outras e que merecem estudos aprofundados de cada uma delas, para que seja possível um trabalho docente que oportunize o real e efetivo desenvolvimento das competências leitora e escritora. 
A figura 1 apresenta uma síntese das competências leitoras que Scarborough $(2001)^{25}$ organizou e que nos ajuda a compreender um dos processos que se constitui ao longo do aprendizado da leitura interligado por duas rotas, sendo uma das rotas de aprendizagem da leitura cada vez mais automática e a segunda cada vez mais estratégica.

Figura 1 - Representação das competências de leitura

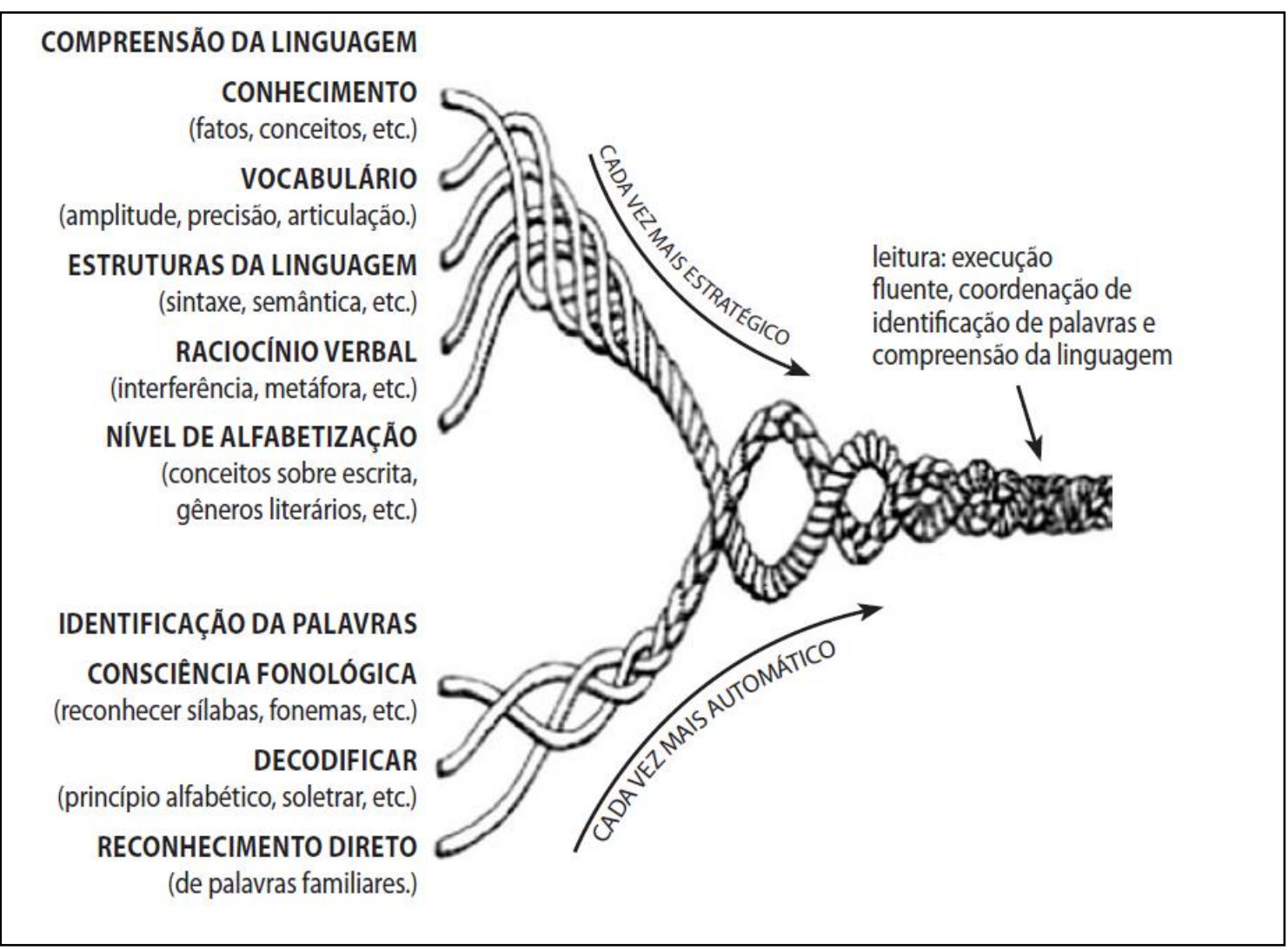

Fonte: SCARBOROUGH, H. S. $(2001){ }^{26}$

Nada mais elementar e coerente é reconhecer que professores das diferentes disciplinas do currículo escolar também necessitam de conhecimentos específicos que envolvam aspectos da alfabetização, do uso e aprendizagem da própria língua, anteriores ao emprego de técnicas oferecidas como solução ao ensino, para que as opções teóricas e metodológicas contribuam mais efetivamente para o desenvolvimento e aprendizagem dos alunos.

\footnotetext{
${ }^{25}$ Utilizamos a versão em português da figura elaborada por Scarborough (2001) apresentada no relatório final sobre alfabetização infantil da Comissão de Educação e Cultura da Câmara dos Deputados citado anteriormente.

${ }^{26}$ SCARBOROUGH, H. S. (2001). Connecting early language and literacy to later reading (dis)abilities: Evidence, theory, and practice. In S. Neuman \& D. Dickinson (Eds.), Handbook for research in early literacy. New York: Guilford Press. p. 97-110.
} 
O segundo aspecto dos efeitos das ideias da responsabilidade do professor diante do trabalho com a leitura e a escrita nas diferentes disciplinas do currículo escolar, coloca em pauta a maneira como cada profissional compreende as ideias dos discursos sobre sua própria competência e que circulam na esfera educacional assumindo ou não responsabilidade por meio da aplicação das prescrições técnicas acolhendo o risco de um trabalho superficial sobre o uso da língua, ou no contraponto abstendo-se do trabalho didático do aprendizado e uso da língua, focando apenas nos conteúdos próprios da sua disciplina.

O desafio está posto, em como articular um trabalho didático com os temas, assuntos e conteúdos próprios de Geografia com a desafiante e complexa tarefa do processo de aprendizagem e uso da língua principalmente para os professores do Ensino Fundamental II, que de uma maneira geral não dominam tais aspectos, frente à precariedade da decodificação de símbolos, interpretação e compreensão da leitura e a produção de textos pelos alunos.

Conscientes da necessidade da tarefa, porém, sem os instrumentos teóricos e metodológicos capazes de apoiar a compreensão sobre como articular o ensino da ciência geográfica ao desenvolvimento das competências leitora e escritora é que nos propomos a realizar a análise crítica de dois documentos elaborados com o objetivo de apoiar os professores da Rede de Ensino do município de São Paulo, os quais apresentamos a seguir.

\subsection{Em busca de respostas para o desenvolvimento das competências leitora e escritora na aula de Geografia - Análise crítica do Referencial de expectativas para o desenvolvimento da competência leitora e escritora no ciclo II do Ensino Fundamental}

Ao longo de nossa trajetória profissional como docente da rede pública de ensino observamos que a organização das aulas de Geografia com atividades que contemplavam apenas a leitura de alguns gêneros textuais não eram suficientes para contribuir efetivamente para o desenvolvimento das capacidades leitora e escritora, pois não tínhamos os critérios necessários que permitissem mediar as dificuldades apresentadas pelos alunos, como resultado o foco se voltava apenas para os conteúdos 
próprios da disciplina de Geografia, reproduzindo muitas vezes conhecimentos de uma ciência morta ${ }^{27}$.

Os apelos de dados tão contundentes quanto ao baixo nível de proficiência de leitura e escrita dos alunos e por isso o forte apelo a todas as áreas do currículo escolar para o compromisso de desenvolver tais competências nas diferentes aulas da Educação Básica, juntaram-se à preocupação de não nos eximirmos da responsabilidade do Ensino de Geografia e de todas as implicações da própria ciência na formação de sujeitos quanto à elaboração da visão de mundo que se constrói principalmente ao longo da escolaridade.

A leitura e a escrita ganharam destaque nas orientações para as práticas docentes e no planejamento de inúmeras políticas públicas a fim de encontrar saídas para o problema que o Grupo de Trabalho de Alfabetização Infantil da Câmara dos Deputados (2007, p.11), classificou como analfabetismo escolar.

A ideia reiterada na esfera educacional sobre o compromisso com o desenvolvimento das competências leitora e escritora e a responsabilidade do Ensino de Geografia na Educação Básica nos levou a iniciar um caminho de pesquisa que nos apoiasse a fim de encontrar as respostas, ainda que provisórias, para as questões desta etapa da pesquisa:

- Como a Geografia, disciplina do currículo escolar, pode contribuir para o desenvolvimento da competência leitora e escritora dos alunos do Ensino Fundamental II?

- Como a competência leitora e escritora pode ser desenvolvida nas aulas de Geografia?

- Como a competência leitora e escritora pode efetivamente contribuir para a elaboração de conceitos por nossos alunos?

A etapa inicial de nossa atividade de pesquisa, ainda sem o tema explícito da oralidade, foco de nossa investigação, se deu por meio do levantamento dos documentos oficiais que a rede de ensino da Prefeitura de São Paulo disponibilizava para apoiar o

27 Utilizamos os conceitos de Ciência Viva/Ciência Morta e como referência apoiamo-nos em dois cientistas, o físico Sébastien Balibar (2012) e do astrofísico Carl Sagan (1989), que apontam a necessidade de se ensinar às crianças a ciência viva através das questões que a própria ciência ainda não tem as respostas. Abordaremos este conceito mais detalhadamente ao explicarmos a estrutura do modelo didático de Sequência Didática que parte de uma "questão-problema" apoiados principalmente por Pozo (1998). 
trabalho dos professores do Ensino Fundamental II quanto ao desenvolvimento da competência leitora e escritora.

Tivemos acesso, com o auxílio dos coordenadores pedagógicos da EMEF General Alcides Gonçalves Etchegoyen, a dois documentos da Secretaria Municipal de Educação de São Paulo relacionados com a nossa temática, o "Referencial de expectativas para o desenvolvimento da competência leitora e escritora no ciclo II do Ensino Fundamental", que neste trabalho será denominado apenas como "Referencial" e o "Caderno de Orientações Didáticas de Geografia", que nomeamos de "Caderno", sendo os dois documentos de $2006^{28}$.

Ao entrar em contato com estes documentos acreditávamos que teríamos algumas indicações que pudessem apoiar as investigações iniciais do nosso trabalho como professora de Geografia e pesquisadora, uma vez que os documentos tratam de alguma forma, da necessidade de orientações específicas para o desenvolvimento das competências leitora e escritora para o Ensino Fundamental II e em destaque para cada uma das disciplinas do currículo escolar.

O Referencial é um dos documentos integrantes do programa "Ler e Escrever", com início em 2005, definido como prioridade dos governos das gestões dos prefeitos José Serra (01/01/2005 a 31/03/2006) e Gilberto Kassab (31/03/2006 a 31/12/2012) e elaborado por Maria José Nóbrega ${ }^{29}$ assessora da rede municipal, à época do projeto.

O Referencial foi organizado, a partir de uma apresentação geral da prioridade da leitura e da escrita como meta da política educacional do município, contendo as concepções de leitura que orientaram o material, orientações de como se realiza a mediação das habilidades de leitura, entre o texto e o estudante leitor, e instruções quanto à organização escolar para implementação do projeto.

Quanto à mediação entre o texto escolhido para o trabalho didático e o aluno, o Referencial apresenta um rol de habilidades a serem exploradas na seguinte ordem: antes, durante e depois da leitura a qual organizamos no quadro 2.

\footnotetext{
${ }^{28}$ Estas orientações aos professores estiveram presentes na rede de ensino municipal até 2013, ano em que assumiu a gestão o prefeito Fernando Hadaad e ocorreu a implantação um novo projeto educacional no município de São Paulo, chamado "Mais Educação".

29 Mestre em Filologia e Língua Portuguesa pela USP e formada em Língua e Literatura Vernáculas pela PUC/SP, atuou em programas de formação continuada junto ao MEC, à Secretaria Estadual de Educação (SP) e à Secretaria Municipal de Educação de São Paulo. Consultora das revistas Carta na Escola e Carta Fundamental e organizadora da série Como eu Ensino. Professora do curso de pósgraduação Formação de Escritores e Especialistas em Produção de Textos Literários do Instituto Superior de Educação Vera Cruz. Disponível em http://goo.gl/Evueqb Acesso em 17 mar. 2016.
} 
Quadro 2 - Rol de habilidades a serem exploradas antes, durante e depois da leitura apresentadas no Referencial de expectativas para o desenvolvimento da competência leitora e escritora no ciclo II do ensino fundamental.

\begin{tabular}{|c|c|c|}
\hline ANTES DA LEITURA & DURANTE A LEITURA & DEPOIS DA LEITURA \\
\hline $\begin{array}{l}\text { - Levantamento do } \\
\text { conhecimento prévio sobre o } \\
\text { assunto. } \\
\text { - Expectativas em função do } \\
\text { suporte. } \\
\text { - Expectativas em função dos } \\
\text { textos da capa, quarta-capa, } \\
\text { orelha etc. } \\
\text { - Expectativas em função da } \\
\text { formatação do gênero } \\
\text { (divisão em colunas, } \\
\text { segmentação do texto...) } \\
\text { - Expectativas em função do } \\
\text { autor ou instituição } \\
\text { responsável pela publicação. } \\
\text { - Antecipação do tema ou } \\
\text { ideia principal a partir dos } \\
\text { elementos paratextuais, como } \\
\text { título, subtítulo, epígrafe, } \\
\text { prefácios, sumários. } \\
\text { - Antecipação do tema ou } \\
\text { ideia principal a partir do } \\
\text { exame de imagens ou de } \\
\text { saliências gráficas. } \\
\text { - Explicitação } \\
\text { expectativas de leitura a partir } \\
\text { da análise dos índices } \\
\text { anteriores. } \\
\text { - Definição dos objetivos da } \\
\text { leitura. }\end{array}$ & $\begin{array}{l}\text { - Confirmação ou retificação } \\
\text { das antecipações ou } \\
\text { expectativas de sentido } \\
\text { criadas antes ou durante a } \\
\text { leitura. } \\
\text { - Localização ou construção } \\
\text { do tema ou da ideia principal. } \\
\text { - Esclarecimento de } \\
\text { palavras-chave para a } \\
\text { determinação dos conceitos } \\
\text { veiculados. } \\
\text { - Busca de informações } \\
\text { complementares em textos de } \\
\text { apoio subordinados ao texto } \\
\text { principal ou por meio de } \\
\text { consulta a enciclopédias, } \\
\text { internet e outras fontes. } \\
\text { - Identificação das pistas } \\
\text { linguísticas responsáveis pela } \\
\text { continuidade temática ou pela } \\
\text { progressão temática. } \\
\text { - Utilização das pistas } \\
\text { linguísticas para compreender } \\
\text { a hierarquização das } \\
\text { proposições, sintetizando o } \\
\text { conteúdo do texto. } \\
\text { - Construção do sentido } \\
\text { global do texto. } \\
\text { - Identificação das pistas } \\
\text { linguísticas responsáveis por } \\
\text { introduzir no texto a posição } \\
\text { do autor. leitor- } \\
\text { - Identificação do lo } \\
\text { virtual a partir das pistas } \\
\text { linguísticas. } \\
\text { - Identificar referências a } \\
\text { outros textos, buscando } \\
\text { informações adicionais se } \\
\text { necessário. }\end{array}$ & $\begin{array}{l}\text { - Construção da síntese } \\
\text { semântica do texto. } \\
\text { - Troca de impressões a } \\
\text { respeito dos textos lidos } \\
\text { fornecendo indicações para } \\
\text { sustentação de sua leitura e } \\
\text { acolhendo outras posições. } \\
\text { - Utilização, em função da } \\
\text { finalidade da leitura, do } \\
\text { registro escrito para melhor } \\
\text { compreensão. } \\
\text { - Avaliação crítica do texto. }\end{array}$ \\
\hline
\end{tabular}

Fonte: Elaboração Ketlin E. T. W. Fiocco.

Para nossa análise organizamos uma amostra de atividades de cada uma das etapas de leitura (antes, durante e depois), somando seis habilidades, no total. Identificamos a competência leitora e/ou escritora que se destinava a habilidade 
analisada. Selecionamos duas atividades de cada uma das habilidades, somando onze propostas de atividades ao todo.

Ao lermos o Referencial verificamos também a necessidade de identificar o papel dos sujeitos envolvidos no processo de ensino e aprendizagem, ou seja, se a instrução da atividade estava voltada para ação do professor e/ou do aluno no sentido de discutirmos posteriormente a formação do sujeito discursivo.

Verificamos, por fim, se havia alguma orientação específica no Referencial que se destinava à Geografia ou que se aplicava ao ensino da ciência no Ensino Fundamental II.

As amostras de análise do Referencial foram organizadas em quadros que compõem o apêndice B de nossa dissertação.

As onze atividades analisadas do Referencial continham prescrições aos professores sobre como desenvolver determinada habilidade relacionada à competência leitora; sendo que, oito delas, continham indícios sobre alguma ação que deveria ser realizada pelo aluno. Por exemplo, no momento "antes da leitura", para a habilidade "Levantamento do conhecimento prévio sobre o assunto", uma das atividades proposta é: "Organize o registro do que os estudantes falam a respeito do assunto agrupando os dados ou ideias segundo as categorias de análise da disciplina". Neste caso a ação do professor está diretamente implicada a uma ação anterior dos alunos, que é "apresentar as ideias iniciais sobre o assunto a ser desenvolvido nas aulas com o apoio do texto escolhido para leitura". As três atividades restantes da amostra apresentaram apenas orientações quanto à ação do professor.

A falta de objetividade e clareza das ações dos sujeitos envolvidos na ação pedagógica, professor e/ou aluno, bem como o foco na ação do professor por meio da apresentação de prescrições, nos indica, entre outros, o caráter técnico do documento em que cabe ao professor a centralidade da ação pedagógica na execução das etapas "antes, durante e depois" da leitura.

$\mathrm{Na}$ amostra com as seis habilidades de leitura identificamos, em quatro delas, orientações relacionadas à Geografia e/ou à Ciência e que posteriormente ganharam um desdobramento no Caderno de orientações didáticas. Neste aspecto consideramos que o documento aponta como critério para a escolha dos textos que serão trabalhados com os alunos, o conteúdo relacionado diretamente com a disciplina que o professor leciona. 
Ao utilizar como critério de escolha do texto, a relação com os conteúdos próprios da disciplina do currículo escolar, o Referencial aproxima os professores, que de alguma maneira, acreditam já trabalharem com gêneros discursivo-textuais diversos.

O documento, ao omitir conceitos importantes acerca do gênero, que envolvem os sujeitos do discurso e consequentemente seus enunciados, reforça para o professor especialista do Ensino Fundamental II o foco na transmissão do conteúdo da disciplina, sem considerar as contribuições dos gêneros discursivo-textuais para um ensino que potencialize o aprendizado da própria Ciência.

Apenas como indicativo nesta etapa de nossa análise do Referencial acerca da complexidade que envolve e diferencia os conceitos de gênero na perspectiva bakhtiniana e o conceito de gênero textual, que ao longo de nosso trabalho consideramos como primordiais articulá-los ao Ensino de Geografia, encontramos em Lima (2012, p.166-167) que realizou uma análise do texto das Orientações Curriculares de Língua Portuguesa para o Ensino Médio, propostas pelo MEC em 2006 a seguinte explicação:

(...) o conceito de gênero concebido pelo Círculo bakhtiniano abarca a essência da língua, a discursividade, considerando primordialmente a construção dos sentidos, tratando-se, dessa maneira, de gênero discursivo, o que vai além do gênero textual (...)A noção de gênero, em Bakhtin, pressupõe uma arquitetônica do enunciado concreto que inclui conteúdo temático, unidade temática, forma composicional, estilo, entonação expressiva, autor, destinatário e aponta, necessariamente, para uma dimensão extra verbal, que inclui os modos de produção e circulação, os fatores sócio históricos, bem como os valores constituídos socialmente.

O que se observou no Referencial é uma tentativa de instrumentalizar os professores da Rede Municipal de Ensino quanto às expectativas de aprendizagem, ou seja, objetivos expressos acerca do que se espera que os alunos aprendam e com isso a implantação de um programa de ensino com foco no desenvolvimento das competências leitora e escritora, entretanto contemplando somente práticas de leitura, ou seja, não há propostas de elaboração textual pelos alunos.

Uma das fragilidades do Referencial é a ausência de propostas de atividades para que os professores oportunizem em suas aulas a elaboração e organização dos enunciados dos alunos por meio da produção de gêneros textuais tanto na modalidade escrita quanto oral e articuladas à leitura. 
Reiteramos que ao propor apenas atividades de leitura o Referencial adota uma concepção de gênero textual que se apresenta exterior ao aluno e não como constitutiva do sujeito por meio de seus enunciados.

Sem dúvidas, a leitura se concebida no contexto dos gêneros discursivo-textuais pode possibilitar a diversos processos, como afirma Fiorin (2012, p.148) "Comprova-se, no processo de leitura, a existência desses universais discursivos, dessas generalizações, dessas abstrações. Ler é apreender esses universais, é fazer generalizações".

Por outro lado, como afirma Joaquim Dolz (2015) professor da Faculdade de Psicologia e Ciências da Educação da Universidade de Genebra (Suíça) em conferência no Brasil em junho de 2015, a escrita de textos convoca e mobiliza sistematicamente a inúmeras leituras, ou seja, propostas de atividades de elaboração de textos podem a um só tempo contemplar diversas possibilidades do próprio conceito de gênero discursivo e de leitura na escola e nas diferentes disciplinas do currículo escolar.

Entre as onze atividades analisadas por nós, encontramos a explicitação de apenas um registro escrito, sobre as ideias iniciais dos alunos quanto ao assunto que será estudado (p. 14) e duas atividades em que exposição oral é indicada, sendo uma a apresentação de um resumo sobre o texto lido pelo aluno (p.38), e outra a realização de um debate (p.22) com o objetivo de discutir sobre as ideias do autor.

Do ponto de vista metodológico o Referencial, ao longo das instruções apresentadas aos professores sobre como mediar a leitura nas aulas de diferentes disciplinas do currículo, confirma a ausência de propostas que tenham a centralidade na elaboração de textos pelos alunos, revelando a concepção dicotômica do processo de desenvolvimento das competências leitora e escritora.

Somente no anexo do documento sob o título "gêneros escritos de apoio à leitura e à preparação ou documentação de textos orais" (p.65) é apresentada uma série de gêneros textuais, como listas, anotações, esquemas, tabelas, roteiro, relato, relatório, resumo e comentários que tem como objetivo apoiar a leitura, como o próprio documento apresenta:

As atividades de registro previstas envolvem, preferencialmente, uma série de gêneros que dão suporte à leitura, à preparação de situações mais formais do uso da fala, bem como o planejamento e a documentação de experiências didáticas, desenvolvendo diversas capacidades fundamentais à leitura e à redação de textos, promovendo experiências com graus de complexidade crescente e através da produção dos registros que resgatem o prazer de escrever. (p. 65) 
Por fim, destacamos que para cada rol de habilidades de leitura de cada uma das etapas, "antes, durante e depois da leitura" do texto, o Referencial apresenta um roteiro de perguntas que tem como objetivo auxiliar o professor na avaliação dos alunos.

Esta proposta parece cumprir o seu papel quanto à avaliação da compreensão do texto lido, mas apresenta lacunas quanto aos enunciados e processos de elaboração de conceitos pelos alunos.

A proposta de avaliar o aluno ao final de cada etapa e ou habilidade, parece indicar a concepção de uma avaliação processual do aprendizado, desde que o professor considere efetivamente os enunciados dos alunos sendo que o documento não oferece subsídios aos professores no que se refere ao apoio às mediações necessárias para que o aluno elabore seus próprios textos durante as aulas.

A materialidade do texto, seja na sua modalidade escrita ou oral, pode contribuir para a avaliação do aluno pelo professor, oferecendo dados, sobretudo, de comparação entre os repertórios que o aluno possuía no início do processo de ensino, e dos avanços durante e ao final das atividades, seja do ponto de vista tanto do gênero discursivotextual, tanto da elaboração de conceitos envolvidos na proposta de ensino da disciplina do currículo escolar.

Temos, portanto, uma mudança no enfoque de uma avaliação que privilegia os resultados, como aqueles apresentados no início do nosso texto, acerca dos níveis de proficiência, para uma avaliação que contemple o desenvolvimento do sujeito por meio de aprendizagens mais significativa e que nos aponte verdadeiramente os efeitos nas estruturas de pensamento por meio de um ensino voltado para apoiar os alunos em seus enunciados.

Ao longo do processo de ensino, a materialidade do texto do aluno, seja na modalidade oral ou escrita pode oferecer ao professor a oportunidade de realizar mediações, considerando o que Vigotski (2010, p. 244) chama de colaboração original entre a criança e o adulto, em um sistema único em que se é possível acessar a zona das possibilidades imediatas ${ }^{30}$.

A zona das possibilidades imediatas envolve outros conceitos que nos parecem fundamentais para a compreensão da importância do trabalho de ensino por gêneros

\footnotetext{
30 Optamos por utilizar a tradução do professor Paulo Bezerra para o conceito de Vigotski sobre a ação íntima entre o desenvolvimento do indivíduo e a ação colaborativa de outra pessoa, que a Prof. ${ }^{\mathrm{a}}$ Dr $^{\mathrm{a}}$. Zoia Prestes (2010) em sua tese de doutorado defende que a tradução mais adequada do russo para a língua portuguesa seria zona de desenvolvimento iminente.
} 
discursivo-textuais, pois possibilita ao professor mobilizar as funções psicológicas superiores, ou seja os pensamentos de níveis cada vez mais abstratos.

Feuerstein, psicólogo romeno radicado em Israel, em seu trabalho com crianças vítimas do holocausto se aproximou sensivelmente do conceito de Vigotski ao conceber outro importante conceito da Experiência de Aprendizagem Mediada (EAM), que tem como postulado sua teoria da modificabilidade cognitiva estrutural como explica Gomes (2002, p. 71-72):

Contrariamente aos testes, Feuerstein, observava através de sua interação com aquelas mesmas crianças (vítimas do holocausto) que elas apresentavam um padrão de raciocínio alterado, bem melhor do que o padrão usual. Elas mostravam potenciais não-demonstráveis nos testes, os quais apenas mediam as capacidades manifestas. Feuerstein buscava ir além das observações pontuais e imediatas dos testes, interagindo do ponto de vista clínico e encontrando, ao mesmo tempo, uma potencialidade à mudança não-detectada em primeira mão. Novamente verificamos a existência de uma semelhança estreita entre Feuerstein e Vigotski, ambos acreditavam na existência de um potencial não-manifesto, no desenvolvimento pela interação sociocultural e na necessidade da elaboração de metodologias avaliativas mais eficientes, voltadas para a potencialidade do indivíduo.

O trabalho didático por meio de gêneros discursivo-textuais pode se qualificar pela Experiência de Aprendizagem Mediada, inicialmente pela via da comunicação, ou seja, pelo processo de elaboração de enunciados pelo aluno e que o professor pode encontrar possibilidades de acessar as funções cognitivas ${ }^{31}$, qualificando nossa investigação acerca dos enunciados dos alunos, como afirma Gomes (2002, p. 78):

Toda interação humana somente se viabiliza pela comunicação. Desse modo, pudemos analisar brevemente que a EAM tem seu foco não especificamente no conteúdo das informações, mas sim no diálogo intencional entre o emissor e o receptor da mensagem. Ambos interagem constantemente, imperando a troca de impressões, os sentimentos sobre o mundo e o intercâmbio de formas de compreensão da realidade. A interação comunicacional e de transmissão no processo de EAM impõe a presença da mobilização cognitiva e afetiva através de uma relação dialógica, interacional entre dois ou mais seres humanos.

Encontramos no Referencial o uso do termo do professor como mediador entre o texto e os alunos, como se o professor, ao desenvolver as técnicas prescritas, obtivesse

\footnotetext{
31 "São processos estruturais e complexos do funcionamento mental que, quando combinados, fazem operar e organizar a estrutura cognitiva. (...) Aproveitando a ideia da teoria do processamento da informação de que todo ato mental abarca três fases fundamentais - entrada, elaboração e saída de informações - Feuerstein estabeleceu a existência das mesmas fases para explicar suas funções cognitivas". (GOMES, 2002, p.110-112)
} 
sucesso neste papel, entretanto não há explicações acerca do conceito e segundo Feuerstein (2014, p. 83) para que a interação seja uma Experiência de Aprendizagem Mediada, ou seja, para além da aplicação de técnicas de ensino, é preciso que existam três parâmetros considerados como universais, a saber: intencionalidade e reciprocidade, transcendência e a mediação do significado.

O exercício de mediação a partir dos três critérios universais de mediação adotados nas teorias de Feuerstein et. al. (2014, p. 92) podem ser resumidos na seguinte passagem:

Para que a interação possua valor de mediação, esta deve incluir, por meio de uma atividade consciente, as características da intencionalidade e reciprocidade, a mediação da transcendência, e a busca por (e descoberta de) significado do funcionamento do mediado e de outros. A Experiência de Aprendizagem Mediada, como interação com qualidade única, é o que cria nos seres humanos a flexibilidade, a sensibilidade, prontidão e o desejo por entender o que acontece e capacidade de generalizar para além do fenômeno isolado sendo vivido. (FEUERSTEIN, 2014, p. 92)

Em especial para a Geografia, mediações que promovam compreensões para além dos fenômenos isolados podem colaborar efetivamente para a estruturação de pensamentos de tipo mais complexos, tão importantes para a elaboração da ideia de mundo por meio de novos enunciados.

Quanto às questões levantadas no início de nossa análise compreendemos que, apesar do caráter mais geral do documento, há especificidades indicadas no Referencial para cada uma das áreas do conhecimento e que devem ser consideradas no desenvolvimento da competência leitora, como o foco nos conceitos que se pretende desenvolver e na escolha dos gêneros relacionado à própria Ciência.

Ao concluirmos esta etapa emergiram para nós indicativos sobre a concepção de sujeito que acompanha o documento que objetivam apresentar referenciais para o professor sobre o desenvolvimento destas competências e que na sua redação exclui toda e qualquer referência à competência escritora.

Desse modo estamos diante de uma proposta que não considera alunos e professores como sujeitos discursivos e que podem elaborar seus próprios textos, sejam eles escritos e ou orais.

Ao concluirmos esta etapa de nossa pesquisa e dada a complexidade da abordagem, sobretudo, no que diz respeito à articulação da Geografia com a leitura e a escrita, delineamos nossa proposição compartilhada a partir dos trabalhos de Schneuwly 
e Dolz (2010, p. 82) de que "é possível ensinar a escrever textos e a exprimir-se oralmente em situações públicas escolares e extraescolares" (Grifo nosso).

Esta afirmação nos abre a possibilidade de análise para a constatação de que os alunos, tidos como sujeitos da ação discursiva podem organizar seus enunciados em gêneros textuais orais e escritos, sem excluir o que afirmamos anteriormente sobre a necessidade da alfabetização, por meio de um ensino que atenda as especificidades do processo de decodificação alfabético.

Há, portanto, um caráter dialógico em nossa pesquisa, como aponta Amorim (2004, p.16) não como método, mas como caminho de investigação, em que passamos a incluir em nossa análise diversas contribuições e críticas, teóricas e metodológicas por meio dos documentos oficiais implementados para as competências leitora e escritora, de autores da Linguística e da Psicologia e os próprios alunos, acolhidos como sujeitos discursivos por meio de seus textos orais e escritos.

\subsection{O desdobramento da análise crítica: Caderno de Orientações Didáticas de Geografia}

Um dos desdobramentos do Referencial de expectativas para o desenvolvimento da competência leitora e escritora no ciclo II do Ensino Fundamental foi o Caderno de Orientações Didáticas para cada uma das disciplinas do currículo escolar. Em sua apresentação Alexandre Alves Schneider (2006), secretário da educação que assumiu o projeto "Ler e escrever" (2005), diz que os Cadernos "pretendem dar continuidade a essas reflexões (quanto ao desenvolvimento das competências leitora e escritora) considerando as especificidades de cada área de conhecimento".

Devido à especificidade do Caderno de Orientações Didáticas para o ensino de Geografia julgamos que seu exame seria complementar ao Referencial analisado anteriormente e que assim ampliaríamos os elementos para compreensão das questões sobre o papel da Geografia no desenvolvimento das competências leitora e escritora e como desenvolvê-la efetivamente nas aulas de Geografia, pois agregava propostas de atividades a partir de gêneros textuais de diferentes esferas de ação, como escolar, jornalístico, literário etc. 
O Caderno se apropria do conceito de "esferas de ação", para justificar o critério de escolha dos gêneros escolhidos como proposta para as atividades com foco, assim como o Referencial, apenas na leitura.

O conceito "esferas de ação" pode ser encontrado em Costa (2009, p. 21) na introdução do Dicionário de Gêneros Textuais como "domínios discursivos" e para Bakhtin (2010, p. 267) como "campos de atividade" onde os enunciados ganham forma e sentido por meio de elementos estáveis, explicado como:

A riqueza e a diversidade dos gêneros do discurso são infinitas porque são inesgotáveis as possibilidades da multiforme atividade humana e porque em cada campo dessa atividade é integral o repertório de gêneros do discurso, que cresce e se diferencia à medida que se desenvolve e se complexifica um determinado campo.

A escola, uma das esferas de ação da sociedade, possui gêneros próprios, chamados por Schneuwly e Cordeiro (2010 p. 91) como gêneros para ensinar, como a aula, prova, ditado etc.

Representados pela proposta do Caderno e somados aos gêneros para ensinar, gêneros de outras esferas da nossa sociedade são levados para as aulas, como a notícia, por exemplo, que pertence à esfera jornalística, mas que, entretanto, ao ingressar na escola, se transforma em um novo gênero, pois é retirado da sua função comunicativa, e discursiva para tornar-se objeto de ensino, ou seja, um gênero escolarizado, como explicam Schneuwly e Cordeiro (2010, p.94).

Além dos gêneros para ensinar e os gêneros escolarizados, Bakhtin (2010, p. 263) faz uma diferenciação entre os gêneros primários e os gêneros secundários, que apoia o critério de escolha dos textos apresentados no Caderno e também como um dos critérios de escolha dos gêneros presentes na Sequência Didática elaborada e aplicada por nós e que será detalhada a partir do capítulo 2 como parte do plano empírico de nossa pesquisa.

Apoiamo-nos na explicação do próprio Bakhtin (2010, p. 263) que distingue os gêneros como:

(...) a diferença essencial entre os gêneros discursivos primários (simples) e secundários (complexos) - não se trata de uma diferença funcional. Os gêneros discursivos secundários (complexos romances, dramas, pesquisas científicas de toda espécie, os grandes gêneros publicísticos, etc.) surgem nas condições de um convívio cultural mais complexo e relativamente muito desenvolvido e organizado (predominantemente o escrito) - artístico, científico, sociopolíticos, etc. No processo de sua formação eles incorporam e 
reelaboram diversos gêneros primários (simples), que se formaram nas condições da comunicação discursiva imediata.

Destacamos dois aspectos que desde já esclarecem nossa perspectiva de análise do ponto de vista da valorização da elaboração textual pelos alunos. O primeiro é que os gêneros primários não são substituídos pelos gêneros textuais secundários, ou seja, o sujeito não deixa de se apoiar nos gêneros primários, que estão intimamente ligados ao cotidiano da ação imediata, logo os utiliza incorporando-os na elaboração dos gêneros secundários, mais complexos e mais organizados.

O segundo aspecto é que os gêneros primários são elaborados pelos sujeitos no cotidiano da ação e os gêneros secundários necessariamente ocorrem em contextos que exigem elaborações mais planejadas, em que seja necessário considerar diversas variáveis, e com níveis de abstrações cada vez mais elevados, sendo a escola uma das esferas de ação mais propícia para que os sujeitos tenham assim a oportunidade para aprender e elaborar gêneros secundários.

O Caderno de Orientações Didáticas de Geografia está assim organizado: a função da Geografia na escola, concepção de leitura e as leituras privilegiadas na área de Geografia, as estratégias de leitura: antes, durante e depois, a mediação do professor, as esferas de ação escolar, literária e jornalística e as respectivas propostas de atividades de cada uma das esferas.

Para a esfera escolar elegeu-se a leitura de mapas, sendo que o documento apresenta um texto inicial com uma visão geral da Cartografia no ensino de Geografia, incluindo um quadro das habilidades de leitura de mapas ao longo da escolarização, que partem das habilidades consideradas mais simples para as mais complexas.

$\mathrm{Na}$ esfera literária apresentou-se uma proposta de trabalho com um poema "Morte e vida Severina" de João Cabral Melo, mas anteriormente há um esforço por meio de um texto inicial e explicativo, de apresentar a relevância do trabalho da esfera literária na área de Geografia.

Já na esfera jornalística o documento privilegia a reportagem como possibilidade de leitura de imagens e do próprio texto jornalístico.

Outro aspecto explícito apresentado pelo secretário Alexandre Alves Schneider, que assumiu a Secretaria Municipal de Educação, há um propósito democrático do Caderno: 
Eles (Cadernos de Orientações didáticas) são fruto de um trabalho coletivo que envolveu equipe da DOT (Diretoria de Orientação Técnica), especialistas de cada área de conhecimento e professores da rede municipal de ensino, constituindo os chamados grupos referência. Os membros de cada grupo participaram ativamente de todo o processo de elaboração, desde as reflexões iniciais sobre as especificidades de sua área, passando pela construção e aplicação das propostas de atividades, adequando-as à realidade das escolas em que atuam, até a revisão final da versão que hoje entregamos à rede. (CADERNO DE ORIENTAÇÃO DIDÁTICA: GEOGRAFIA, 2006, p.3)

O Grupo de Referência foi composto por professores de Geografia da própria rede municipal de ensino que foram indicados por seus diretores e selecionados pela equipe técnica por meio de entrevista que sob a orientação do professor Eduardo Campos, mestre em Geografia, assessor contratado para a elaboração do Caderno de Orientação Didática.

O que se apresenta sobre o pretexto de aproximar os docentes do processo de elaboração de documentos oficiais com um propósito democrático nos parece mais uma aproximação da própria gestão pública com aspectos desconhecidos da realidade escolar provenientes de equívocos das próprias políticas públicas quanto à compreensão dos conceitos teóricos e metodológicos envolvidos no desenvolvimento das competências leitora e escritora e do processo de alfabetização dos alunos.

Desse modo a análise deste Caderno se justifica por apresentar as concepções de outros professores de Geografia da mesma Rede de Ensino que se insere nosso trabalho docente, sobretudo em relação a um ensino de Geografia por gêneros discursivotextuais.

O documento apresenta uma série de propostas para as aulas de Geografia relacionadas com a leitura de diferentes gêneros textuais o que nos possibilitou aprofundar os critérios de análise para além da identificação dos sujeitos das atividades, mas também as esferas de ação, os conteúdos e os objetivos de uso dos gêneros em cada uma das propostas.

Outra questão de nossa análise foi verificar se os Cadernos de Orientações Didáticas supriam a lacuna do Referencial quanto à ausência de habilidades da competência escritora.

Como constituição de nossa segunda amostra elegemos para análise a "proposta de leitura, interpretação e correlação de informações de mapas temático" na p. 33 do Caderno, para este caso os autores-professores da proposta apresentam o mapa como 
um gênero textual, mas sem explicitar esse conceito, que encontramos em Macedo (2015, p. 5):

(...) considerando o mapa como gênero discursivo-textual verbal que também contribui para a formação do aluno enquanto sujeito discursivo numa relação simultânea de articulação com o professor enquanto pesquisador no momento em que planeja e sistematiza suas aulas.

O mesmo autor ainda considera a complexidade da representação do espaço por meio do mapa, como aponta: "conforme estudos de Linguística, (o mapa) como um gênero multissemiótico, ou ainda como linguagem monossêmica ou polissêmica" (MACEDO, 2015, p. 8).

Diante da complexidade do gênero escolhido o Caderno classifica o mapa como um gênero textual da esfera de ação escolar e seguem a mesma proposta de trabalho didático do Referencial, com atividades para as etapas "antes, durante e depois da leitura".

Organizamos um quadro que consta no apêndice C de nossa dissertação onde identificamos em 34 atividades: os gêneros textuais utilizados, os sujeitos das atividades propostas, as competências leitora ou escritora envolvidas nas propostas e se as atividades foram indicadas como recurso para o professor e/ou como produção textual dos alunos.

Para o desenvolvimento da proposta de leitura de mapas temáticos do Atlas Ambiental do município de São Paulo ${ }^{32}$ foram utilizados dez diferentes gêneros textuais que tinham como função serem recurso, no sentido de apoiar o aluno no processo de compreensão e interpretação do gênero textual mapa que era o foco da atividade. Nas atividades em que a função de "produção" de algum gênero pelos alunos foi sugerida pelos autores, estas não foram determinadas e tinham como objetivo principal ao final do processo a avaliação do aprendizado de conteúdos.

Trabalhamos com a ideia de classificar os gêneros textuais como "recurso/produção", ou seja, se o gênero textual utilizado atendia a função de apoiar o ensino ao mesmo tempo que exigia algum tipo de produção, seja do próprio professor, como também dos alunos.

Um exemplo de gênero discursivo-textual que classificamos como "recurso/produção" foi a "aula expositiva dialogada" (p.35). Neste caso utilizamos o

\footnotetext{
${ }^{32}$ Disponível em: http://atlasambiental.prefeitura.sp.gov.br/index.php. Acesso em 21 ago.2016.
} 
conceito de aula como gênero discursivo-textual, de acordo com o que encontramos em Sergio Roberto Costa (2008, p. 22-23) e ainda como um gênero cogestionado conforme apresentado por Schneuwly e Dolz (2010, p. 149), ou seja, um gênero que, ao menos em parte, é produzido pelo próprio desdobramento da aula.

Ao propor uma aula expositiva dialogada se faz necessário a defesa de que os enunciados dos alunos podem e devem ser valorizados pelo professor, em aulas onde a centralidade deixa de ser o professor e passa a ser a ação mediada do aluno, entretanto, ao confrontarmos a concepção de sujeito implícita no Referencial com a concepção de sujeito presente no Caderno, certamente encontramos divergências que nos levam a refletir sobre a importância de tal concepção na educação, uma vez que podem influenciar diretamente nas opções didáticas teóricas e metodológicas dos professores.

Para a etapa "antes da leitura", identificamos no Caderno, dentre as dez atividades analisadas quatro gêneros diferentes, sendo dois como recurso e dois como "produção" e "recurso/produção". Para a etapa "durante a leitura", temos seis diferentes gêneros sendo um utilizado como "recurso" e cinco como "produção" e "recurso/produção". Finalmente para a etapa "depois da leitura" temos três gêneros, todos classificados como "produção".

O gênero textual indicado como recurso diminui progressivamente durante as etapas "antes, durante e depois" da leitura, enquanto que o gênero textual com a função de "produção" e de "recurso/produção" aumenta progressivamente em cada uma das etapas.

O que mais chamou nossa atenção é que na etapa "depois da leitura" todos os gêneros textuais descritos no Caderno só aparecem com a função "produção", com o sentido do aluno apresentar o que aprendeu, ou seja, como objeto de avaliação dos conteúdos da disciplina ao final do processo.

Novamente, nos interessou saber quais propostas de atividades tinham como foco a ação dos alunos e quais eram prescritivas ao professor apenas enquanto técnica didática.

No Caderno há uma tendência em determinar, quais atividades teriam as ações realizadas pelos alunos e quais seriam tarefas do professor, ainda que sem muita clareza e objetividade.

Ao analisarmos as atividades propostas no Caderno identificamos treze ações que deveriam ser desempenhadas pelos professores e dezenove que seriam desempenhadas pelos alunos, indicando uma mudança na abordagem quando o 
documento passa a ser elaborado com a participação dos professores em comparação com o Referencial. É possível observar uma transição do discurso técnico, composto por uma série de ações prescritivas e uma atenção maior voltada para a ação do aluno, através das propostas de atividades.

A participação do professor como autor, no caso dos Cadernos de Orientações Didáticas, reforça a necessidade e a importância da participação dos professores que, na elaboração de documentos e referenciais, tende a suprimir ou reduzir o distanciamento entre os discursos oficiais e o trabalho realizado na sala de aula.

Ainda que Menga Lüdke (2001, p. 15) não estivesse se referindo em seus trabalhos de pesquisa sobre a participação de professores na elaboração de documentos considerados oficiais, e sim do professor como pesquisador, a autora reconhece os desafios do trabalho cotidiano e que impedem muitas vezes o professor de encontrar meios que articulem espaço e tempo do seu trabalho docente e para leituras de estudos, investigações de pesquisas:

O professor do ensino básico é, na maioria das instituições, responsável por um grande número de turmas, nas quais atua introduzindo e organizando o conhecimento escolar no seu campo de saber específico. Toda a sua carga horária de trabalho semanal é, em geral, comprometida com o tempo despendido em sala de aula, tendo, em princípio, um tempo livre destinado à preparação de aulas e a outras atividades. Essa realidade faz com que, em muito poucas instituições de ensino básico, as atividades de pesquisa de professores sejam sistemáticas. (LÜDKE, 2001, p.15-16)

Não podemos deixar de valorizar iniciativas que preservem espaços de discussão, estudo e de alguma forma pesquisa, porém apenas a organização de um grupo de professores para a tarefa de elaborar um Caderno, do qual o foco foi a elaboração de propostas de atividades práticas, se apresenta muito distante das necessidades de formação, discussão, reflexão e pesquisa dos professores.

Os professores participantes do Grupo de Referência da Rede de Ensino da Prefeitura de São Paulo tiveram como tarefa a elaboração de atividades práticas que envolviam a relação da Geografia com gêneros textuais o que foi considerado pelo grupo como uma "tarefa foi árdua, porque cada um de nós trazia na bagagem suas crenças e concepções e a vivência da realidade das distintas escolas municipais, porém tínhamos de organizar um trabalho que pudesse atender toda a rede (...)”. (CADERNO DE ORIENTAÇÕES DIDÁTICAS: GEOGRAFIA, 2006, p.15) 
Buscamos, por meio da análise do próprio texto do Caderno, identificar e compreender as concepções teóricas e metodológicas dos professores de Geografia acerca da proposta de um trabalho didático que desenvolva as competências leitora e escritora, sobretudo os gêneros discursivo-textuais.

Muitas concepções relacionadas às competências leitora e escritora que merecem nossa atenção circulam na esfera educacional, entre elas o conceito de linguagem e de gêneros discursivo-textuais. Limitamo-nos em nossa análise, a ressaltar entre as concepções teóricas e metodológicas utilizadas no Caderno a seguinte afirmação: "Ler com fluência diversos tipos de linguagem é condição necessária para ler textos de diferentes gêneros (...)" (CADERNO DE ORIENTAÇÕES DIDÁTICAS: GEOGRAFIA, 2006, p.24 e 25).

Do ponto de vista prático a disseminação da ideia de que a leitura de diversas linguagens é condição para a leitura de diferentes gêneros nos parece um equívoco, pois desvincula o conceito de linguagem da prática discursiva e da materialidade do gênero textual que, de acordo com Schneuwly e Dolz (2010, p.20), "é através dos gêneros que as práticas de linguagem se materializam nas atividades dos aprendizes".

A linguagem é inerente às práticas discursivas do ser humano e que se materializam em gêneros discursivo-textuais organizados na aula por meio dos enunciados de professores e alunos, implicando em novos significados e novos conhecimentos e não somente pelo uso de gêneros textuais.

Encontramos em Zoia Prestes (2010) uma possível explicação para alusões imprecisas, em muitos casos do conceito de linguagem, como verificado no Caderno, referente às traduções das obras de Vigotski no Brasil, sobretudo daquelas que adotaram as palavras "linguagem escrita", "linguagem falada" ou simplesmente "linguagem" já que, de acordo com a autora os problemas de tradução da questão da "fala" como "linguagem", devem ser considerados, pois podem ter provocado equívocos na compreensão que alcançou o conhecimento dos professores, principalmente por meio de manuais que tinham como objetivo a divulgação das ideias de Vigotski acerca da fala para o processo de desenvolvimento de conceitos e consequentemente para a prática docente.

Outra análise possível para o uso impreciso do conceito de linguagem é um forte apelo do mercado editorial, que utilizando-se da produção em massa de livros didáticos e materiais de multimídia, vendem a proposta de um trabalho didático com "diversas linguagens" ou "novas linguagens". 
Identificamos também uma insistente resposta de autores, ligados à academia, ao mercado editorial por meio da intensa produção de livros e assessoria à produção de materiais de apoio ao professor e de parâmetros curriculares de redes de ensino municipais, estaduais e federal que se mostram reducionista e pasteurizada quanto ao conceito de linguagem aplicado ao ensino.

Encontramos no volume da Coleção Explorando o Ensino, destinado aos professores e disponibilizado pelo Ministério da Educação $(\mathrm{MEC})^{33}$, indicativos da vulgarização do conceito de linguagem que nos parece contribuir para equívocos conceituais ao colocar o professor diante de inúmeras possibilidades, mas sem apontar as potencialidades de cada uma das linguagens para ensinar Geografia, desconsiderando que nem sempre são de domínio pelos docentes, colaborando para trabalhos metodológicos superficiais e fragmentais.

$\mathrm{O}$ documento do MEC a que nos referimos afirma que

A utilização das formas de linguagem não verbal das imagens (em fotografias, desenhos, filmes, maquetes, mapas temáticos, além dos muito usados gráficos, tabelas e mapas em diversas projeções), dos sons (em melodias de músicas) e outras, associadas ou não à linguagem verbal escrita (em gêneros de textos como letras de músicas, poemas, crônicas, reportagens, romances, livros didáticos e paradidáticos etc.), em suportes impressos ou na internet, ou a não escrita (rádio, televisão, palestras, conversas etc.), utilizada de forma diferente da simples explanação em aula expositiva associada ao emprego do livro didático, não pode prescindir da leitura e da escrita. Elas continuam sendo habilidades e competências básicas do ensino, cujas formações devem também, ao mesmo tempo, ser reforçadas por esses outros meios e suceder-lhes como forma de expressão do experimentado. (BRASIL, 2010, p.46)

Tomando as palavras do documento acima para a realidade das práticas docentes realizada pelos sistemas de educação, assumimos que a proposta apresentada nesse documento insere o professor em uma situação de extrema fragilidade, obrigando-o, numa postura autoritária e tecnicista, a promover um trabalho diversificado com os múltiplos gêneros discursivo-textuais, vulgarmente considerados como 'linguagens', que deveriam ser articulados com o desenvolvimento das competências leitora e escritora.

Retomamos a necessidade de considerar a especificidade dos textos próprios das Ciências, ou seja, nem todas as linguagens são próprias da Geografia e se prestarão ao

${ }^{33}$ BRASIL. Ministério da Educação. O Ensino de Geografia e novas linguagens. In: Geografia: ensino fundamental (Coleção Explorando o Ensino; v. 22). Coordenação, Marísia Margarida Santiago Buitoni. Brasília: 2010. p.43-60. 
trabalho didático contrariando assim, os apelos e até imposições enfrentadas pelos professores frente ao mercado editorial ou programas de assessoria e formação continuada, baseadas na ideia da necessidade do uso de "diversas linguagens" ou "novas linguagens".

Luria (1986, p.27) um dos pesquisadores do Círculo de Vigotski ${ }^{34}$ em seus estudos sobre a formação e desenvolvimento do pensamento explica que a linguagem é um complexo sistema de códigos, formado no curso da história social da humanidade sendo assim, cada uma das áreas do conhecimento se apoiam em diferentes sistemas de códigos próprios para organizar o discurso.

Nossa preocupação, além do conceito de linguagem e do forte apelo ao uso de diversas linguagens pelo professor é que mais uma vez, os alunos, que estão em intenso processo de desenvolvimento e aprendizagem sejam colocados no papel de receptores passivos frente a gama de linguagens apresentadas pela escola, mas sem a mediação necessária para que compreendam os enunciados que as compõem e que, sobretudo lhes tirem o direito de vivenciarem experiências de sujeitos discursivos.

Para Bakhtin (2010, p.287) o sujeito do discurso é aquele sujeito que participa de experiências de comunicação discursiva compreendendo a ativa posição responsiva de outros participantes da comunicação. Nesta perspectiva de formação de um sujeito discursivo não é possível que nossos alunos sejam apenas consumidores de "diversas linguagens", sem uma Experiência de Aprendizagem Mediada, conforme a concepção de Feuerstein (2014).

Remetemo-nos ao objeto de ensino e aos conteúdos do Ensino de Geografia, que o Caderno assim aborda: "O que delimita o trânsito dos gêneros de texto entre as diferentes áreas de conhecimento são os conteúdos e objetivos específicos de cada uma delas, e isso implica procedimentos didáticos distintos, de acordo com o que se vai ler" (CADERNO DE ORIENTAÇÕES DIDÁTICAS: GEOGRAFIA, 2006, p.7).

O Caderno apresenta dois critérios que devem se articular para a escolha do gênero: a linguagem específica da ciência que se pretende ensinar e o conteúdo com os objetivos específicos da unidade de ensino.

Os critérios da especificidade dos textos científicos e os conteúdos específicos de ensino, podem auxiliar o professor que, mesmo não sendo um especialista da área de

\footnotetext{
${ }^{34}$ A expressão "Círculo de Vigotski" foi empregada por Brandist, 2012, explicado em uma nota de rodapé, referindo-se a Luria, A. N. Leontiev e ao próprio Vigotski, conferido ao grupo de pesquisadores que tinham em seus trabalhos aspectos convergentes e divergentes do debate relacionados aos estudos realizados.
} 
Línguas, ao se propor realizar o ensino de Geografia por gêneros discursivo-textuais pode ser capaz de abordar com seus alunos as características estáveis do gênero textual, as intenções do autor e principalmente mediar sua produção pelos alunos, pois a probabilidade do professor estar familiarizado com os gêneros discursivo-textuais da esfera acadêmica é maior que outros, entretanto sem limitar as opções de escolhas, uma vez que dependem sobretudo de pesquisa, estudo e interesse do professor.

O documento salienta os critérios de escolha dos gêneros discursivo-textuais pelo professor para suas aulas, entretanto a proposta de atividade contida no Caderno com um gênero textual da esfera literária relacionado unicamente ao conteúdo que se pretende ensinar desarticula os critérios estabelecidos anteriormente.

Sendo o poema "Morte e vida Severina" de João Cabral Melo de 1955, um gênero textual, do ponto de vista dos elementos estáveis da organização dos enunciados, e ao mesmo tempo com denso conteúdo geográfico, não teríamos impedimentos de escolhê-lo para um trabalho sério, interdisciplinar e articulado nas aulas de Geografia, considerando os elementos que Bakhtin (2010, p. 261) afirma constituírem os enunciados dos sujeitos:

Esses enunciados refletem as condições específicas e as finalidades de cada referido campo não só por seu conteúdo (temático) e pelo estilo da linguagem, ou seja, pela seleção dos recursos lexicais, fraseológicos e gramaticais da língua, mas, acima de tudo, por sua construção composicional.

Considerando o conteúdo, o estilo e a construção composicional como elementos constituintes dos enunciados que se apresentam em gêneros discursivos, ponderamos que seu uso pelo professor, apenas seguindo as instruções das atividades do Caderno, sem o conhecimento necessário e específico corre o risco de resultar em um trabalho superficial e fragmentado do ponto de vista do gênero discursivo.

É possível que em situações como esta analisada, em que a proposta era trabalhar com os alunos os conteúdos de Geografia por meio de um poema, professores acreditem que já realizam um ensino que contemple diversos gêneros textuais, entretanto ao aprofundarmos teórica e metodologicamente a questão de um Ensino de Geografia por gêneros discursivo-textuais há aspectos que vão além de uma simples leitura e identificação dos conteúdos relacionados com a unidade de ensino em pauta em determinado bimestre.

Para o conhecimento dos gêneros próprios da ciência geográfica que estão relacionados diretamente com as esferas acadêmica e escolar Guedes (1998, p.19) 
apresenta uma das dimensões do mote da responsabilidade de todas as áreas quanto à competências leitora e escritora:

\begin{abstract}
A tarefa de ensinar a ler e a escrever um texto de história é do professor de história e não do professor de português. A tarefa de ensinar a ler e a escrever um texto de ciências é do professor de ciências e não do professor de português. A tarefa de ensinar a ler e a escrever um texto de matemática é do professor de matemática e não do professor de português. A tarefa de ensinar a ler e a escrever um texto de geografia é do professor de geografia e não do professor de português. A tarefa de ensinar a ler e a escrever um texto de educação física é do professor de educação física e não do professor de português. A tarefa do professor de português é ensinar a ler a literatura brasileira.
\end{abstract}

Consideramos as especificidades dos diferentes textos em cada uma das disciplinas que compõem o currículo escolar para que os alunos tenham garantido o direito de aprender por meio de diversos gêneros discursivo-textuais e principalmente sejam capazes de utilizar os próprios gêneros com suas características comunicativas, de generalizações para níveis cada vez mais elevados de abstração e de expressão discursiva, por isso é que insistimos na utilização, ao menos inicial, de gêneros que o professor domine e posteriormente em um processo de aprendizagem e metacognição do próprio professor, amplie o repertório de gêneros.

Por fim, destacamos que para as duas atividades finais de nossa análise os professores autores propõem a elaboração de um produto final: "Como produto final, solicite que os alunos elaborem, em grupos ou individualmente, um relatório, uma colagem ou um texto argumentativo com base nas reflexões que fizeram durante as aulas e, claro, nas apresentações de todos os grupos". (CADERNO DE ORIENTAÇÕES DIDÁTICAS DE GEOGRAFIA, 2005p. 37)

Como produto final das atividades de leitura de mapas entre as propostas de elaboração de algum gênero discursivo-textual os professores incluem como proposta uma "colagem", ou seja, no mesmo rol de gêneros textuais incluem uma atividade que se apresenta sem maiores explicações dos critérios de escolha ou do significado da própria atividade em si, revelando que mesmo no contexto da proposta de um Caderno ainda prevalecem na escola atividades que parecem sem sentido, por isso, não foi possível saber exatamente a que os autores se referiram ao proporem uma atividade de colagem. 
A opção metodológica apresentada tanto no Referencial, quanto no Caderno foi focalizar a competência leitora por meio de uma estrutura definida em etapas: "antes, durante e depois da leitura" de um gênero discursivo-textual.

Foi possível identificar, o que consideramos um avanço entre o Referencial e o Caderno cumprindo sua função anunciada de complementar às ações indicadas de um modo geral no Referencial e que são desenvolvidas por meio da proposta de atividades mais específicas para o Ensino de Geografia.

Outro aspecto observado no Caderno foi passagem entre as ações que seriam para o professor e para o aluno no sentido de indicar possibilidades de rompimento com uma proposta estritamente técnica e centrada no professor.

O Caderno apresentou equívocos conceituais no que diz respeito ao conhecimento dos professores participantes do Grupo de Referência bem como do assessor sobre os gêneros discursivo-textuais, entretanto, desafiou os professores a pensarem o Ensino de Geografia a partir das competências leitora e escritora.

As elaborações textuais propostas no Caderno tinham como objetivo a avaliação do aprendizado dos conteúdos próprios da Geografia pelos alunos, refletindo metodologias que de uma maneira geral estão em curso nas práticas dos professores.

Há um indicativo dos gêneros textuais que podem ser utilizados nas aulas de Geografia pela especificidade do conteúdo e da própria ciência, entretanto não apresenta explicações necessárias aos professores que não dominam de uma maneira geral o ensino dos gêneros textuais, mas que se propõem ao trabalho; além da confusão entre gênero e capacidade linguística quando apontam o uso de textos "expositivo" e ou “argumentativo" (p. 35 e p. 37).

Para Schneuwly e Dolz (2010, p.51-52) a capacidade linguística se caracteriza como um dos critérios de agrupamentos de gêneros para determinar, com uma coerência mínima, um instrumento de construção da progressão do ensino por gêneros textuais e que podem ser sintetizadas no quadro a seguir:

Quadro 3 - Proposta de agrupamentos de gêneros discursivo-textuais

\begin{tabular}{|l|l|l|}
\hline Domínios sociais de comunicação & \multicolumn{1}{|c|}{$\begin{array}{c}\text { Capacidades de } \\
\text { linguagem dominantes }\end{array}$} & \multicolumn{1}{|c|}{ Nxemplos de gêneros orais e escritos } \\
\hline & $\begin{array}{l}\text { NARRAR } \\
\text { Mimeses da ação através da criação } \\
\text { de intriga }\end{array}$ & $\begin{array}{l}\text { Conto maravilhoso } \\
\text { Fábula } \\
\text { Lenda } \\
\text { Cultura literária ficcional }\end{array}$ \\
& & $\begin{array}{l}\text { Narrativa de aventura } \\
\text { Narrativa de ficção científica } \\
\text { Narrativa de enigma }\end{array}$ \\
& & Novela fantástica \\
& & Conto \\
\hline
\end{tabular}




\begin{tabular}{|c|c|c|}
\hline $\begin{array}{l}\text { Documentação e memorização de } \\
\text { ações humanas }\end{array}$ & \begin{tabular}{l}
\multicolumn{1}{c}{ RELATAR } \\
Representação pelo discurso de \\
experiências vividas, situadas no \\
tempo.
\end{tabular} & $\begin{array}{l}\text { Relato de experiência vivida } \\
\text { Relato de viagem } \\
\text { Testemunho } \\
\text { Curriculum } \\
\text { vitae Notícia } \\
\text { Reportagem } \\
\text { Crônica } \\
\text { esportiva Ensaio }\end{array}$ \\
\hline $\begin{array}{l}\text { Discussão de problemas sociais } \\
\text { controversos }\end{array}$ & \begin{tabular}{l}
\multicolumn{1}{c}{ ARGUMENTAR } \\
Sustentação, refutação e \\
negociação de tomadas de posição.
\end{tabular} & $\begin{array}{l}\text { Texto de opinião } \\
\text { Diálogo argumentativo } \\
\text { Carta do leitor } \\
\text { Carta de reclamação } \\
\text { Deliberação informal } \\
\text { Debate regrado } \\
\text { Assembleia } \\
\text { Resenha crítica } \\
\text { Editorial } \\
\text { Ensaio } \\
\text { Artigo de opinião }\end{array}$ \\
\hline $\begin{array}{l}\text { Transmissão e construção de } \\
\text { saberes }\end{array}$ & $\begin{array}{l}\text { EXPOR } \\
\text { Apresentação textual de diferentes } \\
\text { formas dos saberes }\end{array}$ & $\begin{array}{l}\text { Seminário } \\
\text { Conferência } \\
\text { Comunicação oral } \\
\text { Artigo ou verbete de enciclopédia } \\
\text { Entrevista de especialista } \\
\text { Tomada de notas } \\
\text { Resumo de textos "expositivos" ou } \\
\text { explicativos } \\
\text { Resenha } \\
\text { Relatório científico } \\
\text { Relato de experiência científica }\end{array}$ \\
\hline Instruções e prescrições & $\begin{array}{l}\text { DESCREVER AÇOES } \\
\text { Regulação mútua de } \\
\text { comportamentos }\end{array}$ & $\begin{array}{l}\text { Instruções de montagem } \\
\text { Receita } \\
\text { Regulamento } \\
\text { Regras de jogo } \\
\text { Instruções de uso } \\
\text { Instruções }\end{array}$ \\
\hline
\end{tabular}

Fonte: Schneuwly e Dolz (2010, p.51-52). Adaptação: Ketlin E. T. Wenceslau.

O quadro tem a qualidade de relacionar mais claramente os gêneros textuais, com a capacidade linguística e os domínios sociais de comunicação que se prestam e podem servir ao trabalho didático que tenha como referência a escolha dos gêneros textuais que podem apoiar o ensino, a elaboração de conceitos e a organização dos próprios enunciados pelos alunos.

Ainda na proposta de atividade com o gênero mapa a etapa "durante a leitura" envolvia uma série de perguntas que tinham como objetivo orientar os alunos na elaboração de um texto chamado, pelos autores, de "expositivo":

- Localização: quais os dados referentes ao distrito onde vocês moram? Quais os distritos menos populosos e os mais populosos?

- Interpretação: os distritos populosos estão concentrados em que área (Zona Sul, Zona Norte, Zona Leste, Zona Oeste)? A taxa de crescimento populacional é mais significativa do centro para a periferia ou o inverso?

- Reflexão: como vocês explicam a taxa de crescimento populacional do distrito onde vocês moram? Isso influencia o que na vida de vocês? Esclareça essas perguntas em uma aula expositiva dialogada. 
(CADERNO DE ORIENTAÇÕES DIDÁTICAS DE GEOGRAFIA, ano, 2005, p. 35)

As questões apresentadas no Caderno exemplificam indícios de um trabalho metodológico, a partir de uma questão-problema, o que para Vigotski (2010, p. 237) se faz fundamental na formação de conceitos que surgem sempre no processo de solução de algum problema que se coloca para o pensamento do adolescente.

A questão problema que os alunos deveriam resolver não foi apresentada desde o início do processo, como um desafio para a turma na busca de solução, mas sim ao longo das atividades em que analisavam a complexidade do fenômeno, por meio da leitura de mapas.

Para Pozo (1998, p. 17) a solução de problemas representa uma ferramenta de mediação cognitiva e motivacional para o professor:

A solução de problemas representa para o aluno uma demanda cognitiva e motivacional maior que a execução pelo que, muitas vezes os alunos não habituados a resolver problemas se mostram inicialmente reticentes e procuram reduzi-los a exercícios rotineiros.

O aspecto motivacional a que Pozo se refere é, de acordo com Dolz (2015), um dos maiores desafios do professor, isto é, envolver os alunos em um projeto comunicacional de ensino, que tem como objetivo encontrar solução para uma questão problema, considerando esta uma das etapas do método científico.

O Caderno acompanha o Referencial no tocante à ausência da competência escritora ao não a abordar de forma explícita, além da proposta do gênero textual não como parte do processo de aprendizagem das formas estáveis do próprio gênero e articulado ao mesmo tempo à elaboração de discursos e de conceitos pelos alunos e sim apenas como recurso para apoiar a leitura ou como avaliação ao final do processo de ensino de determinado conteúdo.

Concluímos esta etapa de nossa pesquisa apresentando neste capítulo alguns dos referenciais teóricos primordiais que nos apoiaram na investigação acerca da importância da oralidade na elaboração de conceitos nas aulas de Geografia.

Partimos do princípio da importante presença da leitura e da escrita em documentos e referenciais para os professores e da própria cultura da escola como aspecto comum de apoio ao ensino de diferentes disciplinas, também como um caminho de inserção do Ensino de Geografia nas discussões que se relacionam ao ensino/aprendizado e uso da língua e consequentemente da própria oralidade. 
Buscamos examinar os desafios do ensino contido na difusão da ideia do desenvolvimento da competência leitora e escritora por todas as áreas do currículo escolar, como solução para os problemas identificados como fragilidades e ou ausência de aspectos do processo de alfabetização fundamentais para a aprendizagem e que persistem nos alunos do Ensino Fundamental II.

Entre os desafios do Ensino então a necessidade de diferenciar os processos do aprendizado e uso da língua relacionados aos conceitos de letramento e a alfabetização, o que exige conhecimentos específicos na formação dos professores que têm como plataforma comum de ensino a leitura, a escrita e por sua vez a oralidade.

A partir das interfaces e aproximações de diversos referenciais teóricos, indicamos inicialmente as perspectivas de nossos apontamentos e que são desenvolvidas ao longo deste trabalho, para um Ensino de Geografia que considere os enunciados dos alunos, por meio dos gêneros discursivo-textuais nas modalidades escrita e oral, como parte do processo de elaboração de conceitos, caracterizado por níveis mais elevados de abstrações e generalizações favorecendo o pensamento complexo dos sujeitos em formação. 


\section{Capítulo 2. Uma sequência didática por gênero discursivo oral: a construção teórico-metodológica do problema de ensinar e aprender Geografia considerando a leitura e a escrita}

Nos dois documentos analisados por nós, o Referencial de expectativas para o desenvolvimento da competência leitora e escritora para todas as áreas do Ensino Fundamental II e o Caderno de Orientações Didáticas de Geografia, elaborados pela Rede de Ensino da Prefeitura Municipal de São Paulo, identificamos como principal fragilidade a ausência de uma abordagem por meio de propostas de atividades focadas nas habilidades que contemplassem além da competência leitora, a competência escritora.

Referimo-nos à competência escritora, como a garantia de atividades planejadas para que nossos alunos possam elaborar gêneros textuais tanto escritos, como orais nas aulas de Geografia, colaborando de forma decisiva na formação de sujeitos discursivos.

Sabendo-se da complexidade da tarefa de se ensinar a ler, ensinar a escrever e ensinar Geografia na Educação Básica e compreendendo que tal tarefa se constitui de processos imbricados e fundamentais para a formação de sujeitos é que nos apoiamos na proposta da organização do Ensino em Sequências Didáticas (SD) por gêneros discursivo-textuais como possibilidade de recobrir tais demandas, articulando as especificidades do ensino da ciência geográfica, o processo de alfabetização com foco na formação discursiva e o desenvolvimento da oralidade.

Para os autores franco-suíços Schneuwly e Dolz (2010, p.82) que buscamos como referência para o nosso trabalho, "uma sequência didática é um conjunto de atividades escolares organizadas, de maneira sistemática, em torno de um gênero textual oral ou escrito".

A estrutura da SD proposta por Schneuwly e Dolz (2010) é representada pelo esquema (figura 2) elaborado por estes autores: 
Figura 2 - Esquema da estrutura de sequência Didática por gênero discursivo textual

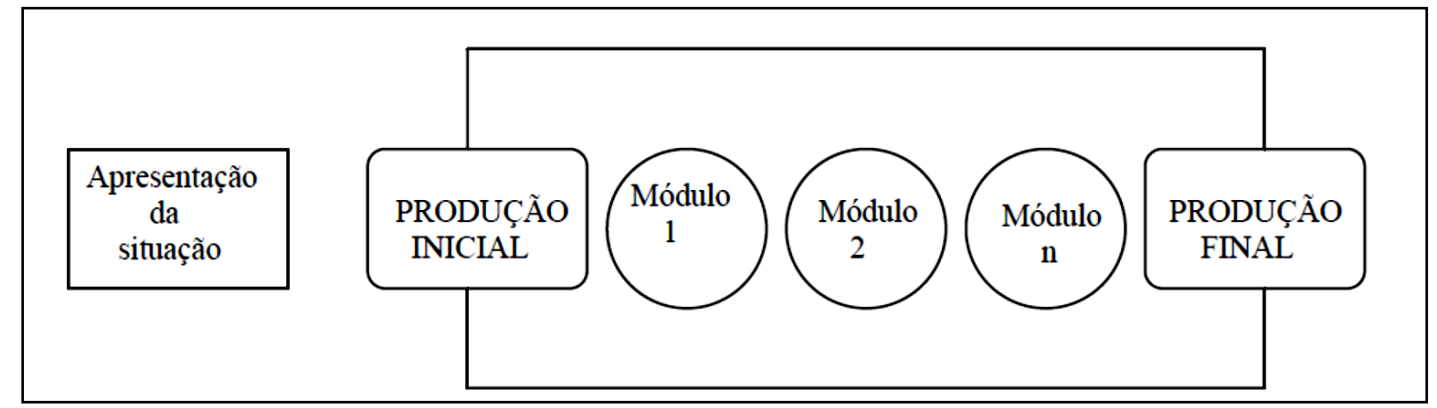

Fonte: Schneuwly e Dolz, 2010, p.83.

Para efeitos desta dissertação, aplicou-se um modelo adaptado da proposta de Sequência Didática da escola de Genebra, cuja elaboração pertence ao Círculo de Pesquisa e Estudos das Fronteiras Teóricas para a formação de professores de Geografia $^{35}$, e que por este motivo ao discorrermos sobre o modelo incluímos ideias e conceitos que estiveram presentes na concepção de nossa SD e que compõem o material empírico de nossa pesquisa como resultado da aplicação nas aulas de Geografia da Educação Básica.

De acordo com os autores do modelo, a SD é dividida em quatro partes, sendo a primeira constituída da apresentação aos alunos de uma situação de estudo, ou seja, uma questão ou problematização a ser estudada e respondida por meio de um gênero textual. Esta situação inicial, expressa por uma questão-problema percorre e justifica todo o esforço intelectual planejado pelo professor por meio de diversas atividades organizadas em SD que serão desenvolvidas pelos alunos dentro de um projeto comunicativo e investigativo.

Nesta primeira parte do modelo de SD encontramos um caminho de acesso para o ensino da Geografia enquanto ciência humana no currículo escolar considerando as contribuições de Pozo (1998, p.13) de uma perspectiva em que os "alunos aprendam a resolver problemas para aprenderem", aprofundando a importância e o valor do trabalho didático a partir de problemas em que a solução não se apresenta como uma resposta pronta de um conhecimento morto e, por conseguinte apenas repetível, oferecendo aos estudantes a falsa impressão de que as teorias são imutáveis ao longo do tempo e do espaço, mesmo frente às demandas contemporâneas das sociedades.

O objetivo desta organização didática partindo de um problema é propor a transição de um conhecimento estático para um conhecimento dinâmico e aberto a

\footnotetext{
${ }^{35}$ Círculo de Pesquisa e Estudos das Fronteiras Teóricas para a Formação de Professores de Geografia, ligado ao LEMADI - Laboratório de Ensino e Material Didático - Departamento de Geografia, USP, coordenado pela Prof. ${ }^{a}$ Dra $^{\mathrm{a}}$ Maria Eliza Miranda a partir de 2009.
} 
novas possibilidades, de uma Ciência Viva em contraposição a uma Ciência Morta, como fomenta o físico Balibar (2012, p. 66) e quando em sua aplicação para o Ensino de Geografia, buscar novas respostas, estimulando novas formas de pensamento acerca das relações complexas no espaço.

Pozo (1998, p.14) aponta para as potencialidades de um ensino pautado na solução de problemas, a importância da aquisição pelos alunos de procedimentos eficazes para a aprendizagem, ou seja, um conjunto de ações organizadas para a consecução de uma meta.

Além da aquisição de procedimentos, a solução de problemas, relaciona-se com a atitude diante da aprendizagem que se objetiva, envolvendo assim, a busca de respostas para suas próprias perguntas ou problemas, como define o próprio Pozo (1998, p.15):

(...) a aprendizagem da solução de problemas somente se transformará em autônoma e espontânea se transportada para o âmbito do cotidiano, se for gerada no aluno a atitude de procurar respostas para suas próprias perguntas/problemas, se ele se habituar a questionar-se ao invés de receber somente respostas já elaboradas por outros, seja pelo livro-texto, pelo professor ou pela televisão. O verdadeiro objetivo final da aprendizagem a solução de problemas é fazer com que o aluno adquira o hábito de propor-se problemas e de resolvê-los como forma de aprender.

Este tipo de ensino é muito desafiante, pois exige do professor uma postura para entender o mundo (Morin 2013) que é basicamente aprender a lidar com as incertezas, no sentido da defesa do trabalho didático a partir da busca de soluções de problemas não abrimos mão do conhecimento, que envolvem conteúdos factuais e conceituais, mas como explica Pozo (1998), que o exame de diferentes pontos de vista possam ser considerados para a construção de um novo conhecimento.

Neste sentido, a incerteza a que Morin (2013) se refere significa trabalhar didaticamente com múltiplas possibilidades de respostas, com base em conhecimentos já construídos historicamente e outros que venham a ser elaborados em uma atitude, sobretudo dialógica, como desafia Balibar (2012, p.66):

Da forma como são ensinadas hoje na escola, parece-me que as ciências não permitem que se perceba a existência de questões não resolvidas, de fenômenos que ainda não foram explicados e entendidos. O professor aparece, pois, na situação de alguém que sabe e julga seus alunos que não sabem ou ainda não sabem. Talvez isso seja a consequência perversa do hábito adquirido de ensinar apenas conhecimentos que podem ser submetidos a uma avaliação baseada no sistema de notas, ou seja, uma avaliação feita a partir de problemas 
que devem ser resolvidos quantitativamente. Ainda que as provas sejam necessárias e que uma estruturação sólida dos conhecimentos ensinados seja evidentemente indispensável, será que não poderíamos imaginar a introdução, a partir do segundo grau, de algumas grandes questões ainda não elucidadas pela ciência atual, mesmo que nem sempre se possa explicar precisamente por que ainda não se encontrou uma explicação para as mesmas?

Desta forma encontramos em Balibar, Pozo e Morin referências que apoiam um ensino que considere o próprio movimento científico como a tentativa de superar problemas encontrados por teorias anteriores e dar uma explicação mais adequada ao contexto em que vivemos, como explica Chalmers (1993, p.64): "Embora nunca se possa dizer legitimamente de uma teoria que ela é verdadeira, pode-se dizer que ela é a melhor disponível, que é melhor do que qualquer coisa que veio antes".

A primeira parte do esquema de Sequência Didática por gênero textual denominada "apresentação da situação" quando relacionamos ao Ensino de Geografia tratou-se, pois, de envolver os alunos por meio de uma questão problema, ao desafio de investigar utilizando atividades estruturadas, diferentes formas de se encontrar as respostas que, mesmo provisoriamente, respondessem ao problema.

A segunda parte do esquema de SD é a "produção inicial" pelos alunos de um gênero textual definido, a partir da situação apresentada. Esta produção textual por sua vez, indica ao professor as necessidades da turma quanto ao aprendizado do gênero, bem como as capacidades linguísticas envolvidas, considerando o ensino da língua. Entretanto, ao inserirmos a proposta no Ensino de Geografia, a leitura inicial pelo professor da primeira produção textual dos alunos já pode indicar o que e como os alunos estão pensando acerca da questão problema, quais palavras estão utilizando para apoiar os conceitos que sustentam suas ideias e por fim as tendências discursivas que a turma apresenta.

O complexo quadro de análise dos textos iniciais dos alunos pode oferecer ao professor a primeira revisão do seu planejamento, para que possa prosseguir com as atividades previstas considerando o que e como os alunos estão dizendo.

A seguir, a terceira parte é composta por atividades organizadas em módulos a fim de tratar das necessidades do uso e aprendizado da língua e que surgiram na primeira produção textual, além das características estáveis do gênero estudado, as capacidades linguísticas com o objetivo comunicativo, ou seja, que os alunos elaborem melhor seus textos. Quando articulados ao Ensino de Geografia, as atividades 
envolvendo os assuntos ou temas, bem como os conteúdos necessários para a discussão a ser desenvolvida pelos alunos em seus textos, serão contempladas nos módulos da SD.

A organização das atividades em módulos tem como objetivo abordar a progressão do ensino de maneira sistemática e aprofundada, constituídos em um movimento constante entre a consolidação, a continuidade e a novidade do ensino e que pode ser assim definida:

O movimento geral da sequência didática vai, portanto, do complexo para o simples: da produção inicial aos módulos, cada um trabalhando uma ou outra capacidade necessária ao domínio de um gênero. No fim, o movimento leva novamente ao complexo: a produção final. (SCHNEUWLY e DOLZ, 2010, p.88)

Por fim, a quarta parte, em que os alunos reelaboram o gênero textual, desenvolvendo ou reelaborando a questão-problema apresentada no início da aplicação da SD colocando em prática o que aprenderam, em duas perspectivas: a primeira é que o aluno junto com o professor, poderá medir os progressos alcançados e a segunda para uma avaliação do tipo somativo ${ }^{36}$, que incidirá sobre os aspectos trabalhados durante a sequência. (SCHNEUWLY e DOLZ, 2010, p.84)

Dolz (2015) expressa sua preocupação sobre como evitar a derivação técnica da proposta, ou seja, o risco da aplicação não inteligente das ferramentas do modelo de SD pelos professores como se a simples aplicação do modelo didático fosse suficiente para que os alunos aprendam a escrever diferentes gêneros discursivo-textuais.

Para que o modelo didático de Sequência Didática de Dolz; Noverraz e Schneuwly (2010) ultrapasse uma visão e uma prática de aplicação de um conjunto de técnicas é preciso superar a lógica da repetição mecânica e reunir uma série de condições teóricas e metodológicas para que funcionem como espaços de aprendizagem (DOLZ, 2015).

Em nossa prática docente o modelo de Sequência Didática de Schneuwly e Dolz (2010) se constituiu como uma ação prospectiva para pensarmos o Ensino de Geografia, a partir de uma perspectiva sociocultural considerando os enunciados dos alunos e professores em uma concepção ampla de ensino, Ciência e de sujeitos.

\footnotetext{
${ }^{36}$ Tipo de avaliação que ocorre ao final da instrução com a finalidade de verificar o que o aluno efetivamente aprendeu. Inclui conteúdos mais relevantes e os objetivos mais amplos do período de instrução; visa à atribuição de notas; fornece feedback ao aluno (informa-o quanto ao nível de aprendizagem alcançado), se este for o objetivo central da avaliação formativa; e presta-se à comparação de resultados obtidos com diferentes alunos, métodos e materiais de ensino. Foi assim classificada por Benjamin Bloom e seus colaboradores, cujos estudos apontam para outros dois tipos de avaliação: a formativa e a diagnóstica. (MENEZES, E. T.; SANTOS, T. H, 2001).
} 
A perspectiva de ensino sociocultural corresponde ao complexo desenvolvimento e aprendizagem humana a partir da relação profunda do sujeito com o meio social e cultural por meio dos instrumentos psicológicos e simbólicos ${ }^{37}$, tendo a fala papel fundamental.

Alex Kozulin (2000, p.12) afirma que foi Vigotski o autor da teoria sociocultural $^{38}$ que explica as relações entre a cognição humana e os processos de aprendizagem que ocorrem nas funções psicológicas dos sujeitos, que podem ser: naturais e culturais.

As funções psicológicas naturais se desdobram em uma dinâmica natural no curso do desenvolvimento e maturação, mas ao sofrerem algum tipo de intervenção dos instrumentos simbólicos e culturais, principalmente por meio da fala, a dinâmica pode ser totalmente modificada transformando-as em funções psicológicas culturais, que tem como implicação a regulação das funções psicológicas naturais, que aos poucos vão sendo interiorizadas pelo sujeito.

Schneuwly (2010, p.20-21) explica que o modelo didático de Sequências Didáticas, no caso das pesquisas desenvolvidas por seu grupo de pesquisa na Suíça para o ensino da língua francesa, adota a explicação interacionista de Vigotski para a compreensão da relação entre o conhecimento e a aprendizagem por meio do gênero que é um instrumento de fator de desenvolvimento das capacidades individuais, como afirma:

O instrumento torna-se, assim, o lugar privilegiado da transformação dos comportamentos: explorar suas possibilidades, enriquecê-las,

37 Kozulin (2000) explica que o conceito de instrumento psicológico é fundamental para a teoria psicológica de Vigotski e corresponde aos recursos simbólicos como signos, símbolos, textos, tabelas, gráficos etc. e que ajudam o indivíduo a dominar suas próprias funções psicológicas "naturais" como atenção, percepção e memória.

38 Adotamos neste trabalho a expressão "sociocultural" para a teoria "histórico-cultural" de Vigotski acompanhando Kozulin (2000). Encontramos em Wertsch, Río e Alvarez (1995, p. 6-7) a seguinte explicação: "Nós concordamos que "histórico-cultural" e "sócio histórico" são termos mais adequados quando se referem à herança que provem de Vigotski, Leontiev, Luria, e muitos outros psicólogos soviéticos. No entanto, acreditamos que "sociocultural" é um termo melhor quando se trata de lidar com a forma como este patrimônio foi apropriada nos debates contemporâneos nas ciências humanas, pelo menos no Ocidente. A razão para isso tem a ver com a forma como a cultura é entendida por todas as partes envolvidas. (...) Seguidores de Vigotski assumiram uma noção de cultura que está claramente em consonância com os pressupostos universalistas sobre a unidade psíquica da humanidade e reivindicações evolucionistas, muitas vezes associados a estas concepções". (Tradução nossa) No original: We would agree that "cultural-historical" and "socio-historical" are more appropriate terms when referring to the heritage we recognize from Vigotski, Leontev, Luria, and many other Soviet psychologists. However, we believe that "sociocultural" is a better term when it comes to dealing with how this heritage has been appropriated in contemporary debates in the human sciences, at least in the West. The reason for this has to do with how culture is understood by the various parties involved. (...) Vigotski's followers assumed a notion of culture that is clearly in line with universalist assumptions about the psychic unity of humankind and evolutionist claims often associated with these assumptions. 
transformá-las são também maneira de transformar a atividade que está ligada à sua utilização. (SCHNEUWLY e CORDEIRO , 2010, p. 21)

A explicação de Schneuwly e Cordeiro nos parece enriquecer ainda mais a proposta de Sequências Didáticas por gêneros discursivo-textuais distanciando-a de um modelo puramente técnico de ensino, ao focalizar as possíveis transformações das funções psicológicas mediadas pelo instrumento que necessariamente envolve a apropriação ativa pelo sujeito, como explica:

$\mathrm{O}$ instrumento, para se tornar mediador, para se tornar transformador da atividade, precisa ser apropriado pelo sujeito; ele não é eficaz senão à medida que se constroem, por parte do sujeito, os esquemas de sua utilização. Esses esquemas de utilização são plurifuncionais: por meio deles o instrumento faz ver o mundo de uma certa maneira e permite conhecimentos particulares do mundo (...).(SCHNEUWLY e CORDEIRO, 2010, p. 22)

O movimento de aplicação de uma Sequência Didática por gêneros discursivotextuais, conforme o modelo apresentado pelo grupo dos pesquisadores Schneuwly e Dolz, implica necessariamente na participação ativa dos alunos na elaboração de gêneros textuais.

Nossa insistência em destacar a importância de um trabalho que valorize a ação dos alunos se justifica entre outras, pela adoção por nós de uma abordagem cultural da Geografia que, desta perspectiva de ciência, assume novas interpretações para os desafios da territorialidade espacial da existência humana, e também das representações do espaço que os homens estabelecem a partir de suas próprias experiências e vivências, que incorporadas ao ensino de Geografia passa a ter como ponto de partida o próprio sujeito do espaço.

Para a perspectiva da Geografia Cultural destacamos as ideias de Paul Claval (2013, p.155) que afirma:

A Geografia que se reconstrói com a virada cultural não esquece a existência de limites ligados ao ambiente e à distância, porém liga-se, ainda assim, à maneira como os atores geográficos funcionam no mundo em função de suas aspirações, de seus sonhos e de suas antecipações. Para isso, os pesquisadores mobilizam novas ferramentas: exploram as representações e os imaginários que se interessam pelo que as mulheres e os homens constroem, o aqui e o lá do mundo sensível. Eles são indispensáveis aos indivíduos e aos grupos para avaliarem o real, fazer seus julgamentos e guiar suas ações. (grifos do autor) 
Para Claval é fundamental que ocorra investigações que considerem as representações dos sujeitos acerca do espaço, como princípio de pesquisa que pode ser aplicado ao Ensino de Geografia por meio do modelo de Sequências Didáticas por gêneros discursivo-textuais ao propiciar a expressão do processo de elaboração das representações, ou seja, da construção da visão de mundo dos nossos alunos.

Ruy Moreira (2013, p.106) explica a importância dos métodos de investigação e de ensino da Geografia ao considerar as representações dos sujeitos do espaço:

Por que é importante essa consciência da representação? Porque uma vez, assim entendida, a ideia pode ser submetida ao fio crítico do debate, permitindo-nos: 1) refletir sobre nossas leituras de mundo; 2) clarificar o modo como as produzimos e praticamos; 3) desfazer o dogma do conhecimento; 4) estabelecer os limites da teoria; 5) perceber que várias alternativas de representação são possíveis e; compreender o poder das ideias na transformação da sociedade em que vivemos.

A perspectiva da Geografia Cultural, que utiliza como uma das ferramentas de investigação as representações dos sujeitos do espaço, quando aplicada ao Ensino na Educação Básica possibilita considerar que nossos alunos são capazes de elaborar novas ideias acerca dos problemas e fenômenos do espaço, como explicou Moreira na citação anterior, e ideias podem e devem ser discutidas, para mais uma vez serem reelaboradas continuamente, num processo vivo de constituição do conhecimento e da própria ciência.

Milton Santos (2000), em um debate que ocorreu no Departamento de Geografia da FFLCH (USP) em 04 de outubro de 2000 por ocasião da publicação do Manifesto sobre o papel ativo da Geografia ${ }^{39}$ reivindicou a necessidade de se fazer o debate das ideias, criticando duramente seus debatedores que em sua opinião não enfrentaram os problemas próprios da Geografia ao discutirem a escolha de determinadas palavras e não os conceitos envolvidos.

Assim como SANTOS (2000) acreditamos que precisamos enfrentar o debate das ideias também no Ensino de Geografia e que os professores da Educação Básica participem ativamente assumindo a responsabilidade de um ensino que valorize a voz e o pensamento dos alunos, bem como as consequências que advém da formação de sujeitos discursivos.

\footnotetext{
${ }^{39}$ Tivemos acesso ao debate do professor Milton Santos no auditório de Geografia da FFLCH (USP) por meio de gravação audiovisual disponível em: https://www.youtube.com/watch?v=xpM6M08rI3E Acesso em 04 abr. 2016.
} 
Considerar o trabalho didático com ideias diferentes que podem ser apresentadas pelos alunos em seus textos pode provocar desestruturas no modo de pensar do próprio professor, que necessita das ferramentas teóricas e metodológicas para apoiar a estruturação dos discursos dos alunos por meio dos gêneros discursivo-textuais oral e escrito, com todos os elementos estáveis ${ }^{40}$ que os compõem.

\subsection{A oralidade como gênero discursivo-textual: possibilidades e contribuições para pensar o ensino de Geografia}

Neste ponto de nossa pesquisa a concepção dos gêneros textuais escritos e orais consolidou-se para nós como possibilidade real da garantia da expressão de enunciados ${ }^{41}$ dos alunos para o desenvolvimento de seus processos cognitivos, levandoos a pensar de maneira contextualizada e complexa acerca dos problemas da sociedade a partir do ponto de vista de um dos seus elementos: o espaço geográfico.

Ainda que esta prática metodológica de SD por gêneros discursivo-textuais seja inicialmente desconhecida por professores de Geografia, julgamos que esta se constitui numa possibilidade efetiva de ensino e aprendizagem, sobretudo pelos aspectos de uma abordagem cultural da própria Geografia, ou seja, uma abordagem que considera o conjunto das representações que os sujeitos do espaço geográfico elaboram em suas investigações.

Para compreender e aplicar a concepção dos autores Dolz e Schneuwly (2010) se fez necessário compreender "as especificidades das práticas de linguagem que são objeto de aprendizagem, as capacidades de linguagem dos aprendizes e as estratégias de ensino pela sequência didática." (DOLZ; SCHNEUWLY, 2010, p. 43), além de focalizar ações que aliassem à proposta de SD por gêneros discursivo-textuais ao ensino da Geografia.

As SD por gêneros discursivo-textuais apresentam uma tendência educacional mundial da aplicação em processos didáticos sobre as competências de leitura e escrita na Educação Básica, e ao mesmo tempo uma inovação se tratando de outra disciplina, neste caso a Geografia e não, tradicionalmente, a Língua Portuguesa.

\footnotetext{
${ }^{40}$ Quanto aos elementos estáveis que caracterizam determinado gênero discursivo-textual incluem-se nesta concepção o processo enunciativo implicado em sua análise e por tanto dinâmico e mutável.

${ }^{41}$ De acordo com Bakhtin (2010, p.261): "O emprego da língua efetua-se em forma de enunciados (orais e escritos) concretos e únicos, proferidos pelos integrantes desse ou daquele campo da atividade humana".
} 
As incursões pelo trabalho didático de elaboração e aplicação de Sequências Didáticas de Geografia por gêneros discursivo-textuais com alunos da Escola Básica Pública iniciou-se em agosto de 2010, antes mesmo do nosso ingresso no Programa de Pós-Graduação, com a nossa participação no Círculo de Pesquisa e Estudos das Fronteiras Teóricas para a Formação de Professores de Geografia, ligado ao LEMADI Laboratório de Ensino e Material Didático - Departamento de Geografia, USP, coordenado pela prof. ${ }^{a}$ Dr $^{a}$ Maria Eliza Miranda.

A aplicação de Sequências Didáticas por gêneros discursivo-textuais em aulas de Geografia é parte da proposta teórica e metodológica que compõe os estudos e as pesquisas do Círculo de caráter dialógico entre os sujeitos envolvidos e as "fronteiras teóricas para a formação de professores" (MIRANDA, 2010) entre elas a Teoria da Experiência de Aprendizagem Mediada de Reuven Feuerstein, a Filosofia da Linguagem de Mikhail Bakhtin e a ideia do Pensamento Complexo e da Religação dos Saberes de Edgar Morin.

Estas fronteiras teóricas permearam e fundamentaram os processos de elaboração e aplicação de Sequências Didáticas para o ensino de Geografia no sentido da formação de sujeitos discursivos a partir da Educação Básica em que estivemos inseridos participando dos estudos, discussões, elaborações e aplicações de Sequências Didáticas.

No âmbito da pesquisa para a formação de professores do Círculo de Pesquisas e Estudos participamos de três aplicações de Sequências Didáticas elaboradas e aplicadas em aulas de Geografia nos anos de 2010, 2011 e 2013 que foram sintetizadas no quadro 4. 
Quadro 4 - Caracterização geral das Sequências Didáticas de Geografia por gênero discursivo-textual, elaboradas e aplicadas em escola pública de Educação Básica

\begin{tabular}{|c|c|c|c|c|c|c|c|c|c|c|}
\hline $\begin{array}{l}\text { Período de } \\
\text { aplicação }\end{array}$ & $\begin{array}{l}\text { Número de } \\
\text { Alunos }\end{array}$ & Nível do Ensino & $\begin{array}{l}\text { Etapa: } \\
\text { Série/Ano }\end{array}$ & $\begin{array}{l}\text { Ciclo de } \\
\text { acordo } \\
\text { com os } \\
\text { PCN's }\end{array}$ & Turmas & $\begin{array}{c}\text { Gênero } \\
\text { discursivo-textual } \\
\text { ESCRITO }\end{array}$ & $\begin{array}{l}\text { Gênero } \\
\text { discursivo- } \\
\text { textual } \\
\text { ORAL }\end{array}$ & $\begin{array}{l}\text { Tipos de } \\
\text { registro }\end{array}$ & $\begin{array}{l}\text { Tempo de } \\
\text { registro }\end{array}$ & $\begin{array}{l}\text { Contexto das } \\
\text { elaborações } \\
\text { textuais }\end{array}$ \\
\hline $\begin{array}{l}2^{\circ} \text { Semestre } \\
2010\end{array}$ & 82 & $\begin{array}{c}\text { Educação Básica } \\
\text { - Ensino } \\
\text { Fundamental - } \\
\text { Ciclo II }\end{array}$ & $\begin{array}{c}5^{\mathrm{a}} \text { séries } / 6^{\circ} \\
\text { anos }\end{array}$ & $3^{\circ}$ & $\begin{array}{l}\text { A } \\
\text { B } \\
\text { C }\end{array}$ & Artigo de opinião & Júri simulado & $\begin{array}{l}\text { Áudio } \\
\text { visual/ }\end{array}$ & $\begin{array}{l}\text { 1h } 55 \min \\
42 \mathrm{~s}\end{array}$ & SD: Belo Monte \\
\hline $\begin{array}{l}2^{\circ} \text { Semestre } \\
2011\end{array}$ & 66 & $\begin{array}{c}\text { Educação Básica } \\
\text { - Ensino } \\
\text { Fundamental - } \\
\text { Ciclo II }\end{array}$ & $\begin{array}{c}8^{\mathrm{a}} \operatorname{séries} 9^{\circ} \\
\text { anos }\end{array}$ & $4^{\circ}$ & $\begin{array}{l}\text { A } \\
\text { C }\end{array}$ & Dissertação & $\begin{array}{l}\text { Debate } \\
\text { Regrado }\end{array}$ & $\begin{array}{l}\text { Áudio } \\
\text { visual }\end{array}$ & $\begin{array}{l}1 \mathrm{~h} 19 \min \\
25 \mathrm{~s}\end{array}$ & $\begin{array}{l}\text { SD: A } \\
\text { submissão dos } \\
\text { padrões sociais } \\
\text { e ambientais das } \\
\text { populações dos } \\
\text { países ao } \\
\text { modelo } \\
\text { econômico } \\
\text { financeiro - } \\
\text { estudos de casos } \\
\text { reais para uma } \\
\text { visão de mundo } \\
\text { mais crítica. }\end{array}$ \\
\hline $\begin{array}{l}2^{\circ} \text { Semestre } \\
2013\end{array}$ & 76 & $\begin{array}{c}\text { Educação Básica } \\
\text { - Ensino } \\
\text { Fundamental - } \\
\text { Ciclo II }\end{array}$ & $\begin{array}{c}6^{\text {a }} \text { séries } 7^{\circ} \\
\text { anos }\end{array}$ & $3^{\circ}$ & $\begin{array}{l}\text { A } \\
\text { B } \\
\text { C }\end{array}$ & Dissertação & $\begin{array}{l}\text { Debate } \\
\text { Regrado }\end{array}$ & $\begin{array}{l}\text { Áudio } \\
\text { visual }\end{array}$ & $\begin{array}{l}3 \mathrm{~h} 11 \mathrm{~min} \\
19 \mathrm{~s}\end{array}$ & $\begin{array}{l}\text { SD: O Brasil vai } \\
\text { de quê?? }\end{array}$ \\
\hline TOTAL & 224 & - & - & - & - & 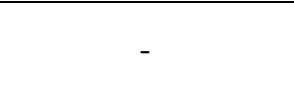 & - & - & $\begin{array}{c}\text { 06h 26min } \\
26 \mathrm{~s}\end{array}$ & \\
\hline
\end{tabular}

Fonte: Elaboração Ketlin E. T. W. Fiocco. 
Ao planejar as Sequências Didáticas (SD) de Geografia por gêneros discursivotextuais, nos deparamos com a necessidade de organizar em todas elas atividades de linguagem verbal oral, principalmente na versão Debate Regrado, inicialmente com foco na aprendizagem da comunicação e expressão de ideias, opiniões e posicionamentos sobre determinado tema de estudo, compreendendo assim, que tal atividade seria fundamental para o aprendizado da ciência, o desenvolvimento da capacidade da linguagem argumentativa e a formação do pensamento crítico de nossos alunos.

$\mathrm{O}$ avanço em nossas pesquisas acerca da linguagem verbal oral na dimensão gênero discursivo-textual nos possibilitou compreender outros aspectos do aprendizado e do desenvolvimento que não considerávamos ao classificar o debate apenas como mais uma atividade de ensino.

Partimos então de um interesse e um desejo profundo de escutar os enunciados dos alunos, apesar da realidade que observamos durante nossas aulas em que muitos deles não são capazes de expressar alguma ideia coerente, seja por meio de um texto escrito ou oral, imersos em um conhecimento de baixa complexidade, tão espontâneo que nos levou a repensar a escola e a prática docente.

Um aspecto importante a ressaltar é que esta pesquisa se inscreve, na perspectiva de nossa própria prática, com alunos reais, dentro de aulas de Geografia em uma escola pública, com falas e produções textuais coletadas durante a aplicação de uma Sequência Didática de Geografia por gêneros discursivo-textuais e que permeiam todas as reflexões aqui apresentadas.

Neste contexto, além dos alunos participantes como sujeitos ativos do plano empírico desta pesquisa, ao mesmo tempo, articulamos e ampliamos a nossa própria participação como sujeito, professora autora, aplicadora da Sequência Didática e pesquisadora, com o foco e método que a produção científica exige.

Trata-se, pois o que Edgar Morin (2011, p.29) aponta como um dos sete saberes necessários à educação do futuro, o enfrentamento dos riscos do erro e da ilusão como uma das cegueiras do conhecimento em que:

Devemos compreender que existem condições bioantropológicas (as aptidões do cérebro/mente humana), condições socioculturais (a cultura aberta, que permite diálogo e troca de ideias) e condições noológicas (as teorias abertas), que permitem "verdadeiras" interrogações, isto é, interrogações fundamentais sobre o mundo, sobre o homem e sobre o próprio conhecimento. Devemos compreender que, na busca da verdade, as atividades auto observadoras devem ser inseparáveis das atividades observadoras, as autocríticas, inseparáveis das críticas; os processos reflexivos, inseparáveis dos processos de objetivação." 
No processo de elaboração do conhecimento e da avaliação crítica da própria prática docente compreendemos a importância do fortalecimento de pesquisas que priorizem o trabalho do professor sujeito e pesquisador que apoiem o combate aos erros e ilusões, a que se refere Morin, frente a tantas opções teóricas e metodológicas que se apresentam contrárias ao real interesse da formação discursiva, científica e humana dos nossos alunos.

Fundamentamos os argumentos sobre a participação maior dos professores em processos investigativos acerca do ensino e aprendizagem, sobretudo a partir das pesquisas de Menga LÜDKE (2011), entre outros autores que apoiam a ideia de que os professores podem produzir novos conhecimentos a partir da relação entre diferentes referenciais teóricometodológicos e suas escolhas didáticas resultando em diversas práticas docentes desenvolvidas com maior autonomia e criticidade, entretanto, reconhecendo as dificuldades enfrentadas pelos professores em articular as jornadas de trabalho e as atividades de estudo e pesquisa.

Buscou-se no trabalho com Sequências Didáticas por gêneros discursivo-textuais um caminho teórico e metodológico que respondesse às demandas sociais e cognitivas dos alunos, para a formação de sujeitos, a necessidade de um Ensino de Geografia mais significativo e ativo no currículo escolar articulado ao desenvolvimento da oralidade imbricado à leitura e a escrita.

Retomamos as questões iniciais de nossa investigação sobre a relação da Geografia e o desenvolvimento da competência leitora e escritora na Educação Básica confrontando com a análise que realizamos do Referencial e do Caderno de Orientações Didáticas, principalmente quanto à ausência da produção textual pelos alunos e do enfoque de orientação apenas técnicas aos professores.

Articulamos, assim, esta análise ao nosso interesse inicial de garantir aos alunos o espaço da fala, com o objetivo da organização de suas ideias e o desenvolvimento da criticidade a partir das ideias dos colegas, porém ao compreendermos que os espaços da fala ao qual nos referimos são conceitualizados como gêneros discursivo-textuais da modalidade oral sendo fundamentais para o desenvolvimento de pensamentos de tipo mais complexo e de nível mais abstrato, nossa investigação se reorganizou e passamos a focalizar a seguinte problematização:

- "Qual a importância da oralidade para o processo de elaboração de conceitos pelos alunos no contexto de aplicação de uma Sequência Didática de Geografia por gêneros discursivo-textuais em turmas de $7^{\circ}$ anos da escola pública?”. 
Entre as Sequências Didáticas elaboradas e aplicadas por nós, apresentadas no quadro 4, optamos por analisar a SD “O Brasil vai de quê?”, em primeiro lugar por ter sido realizada no período em que já estávamos com a atenção voltada para a definição e o desenvolvimento de nossa pesquisa de mestrado e em segundo lugar, por julgarmos que as duas experiências anteriores tiveram papel fundamental em nossa conduta somativa para as reflexões e críticas aqui apresentadas, ou seja, a internalização dos processos de elaboração de um modelo didático.

A conduta somativa como explica Gomes (2002, p. 128) organiza a percepção através da capacidade do indivíduo de controlar, analisar e organizar os dados do mundo pela via da quantificação e é uma das funções cognitivas do modelo de Reuven Feuerstein utilizado para explicar os processos estruturais e complexos do funcionamento mental.

Já citamos anteriormente, como parte de nosso referencial teórico o modelo de Funções Cognitivas (FC) de Reuven Feuerstein, que nos apoia na compreensão acerca do complexo funcionamento das estruturas de pensamento do ser humano em uma relação dinâmica entre o biológico e o cultural, uma vez que adotamos a perspectiva sociocultural, ou seja, um ensino que se preocupa com o desenvolvimento e aprendizagem dos sujeitos por meio das relações estabelecidas, sobretudo por meio da fala.

Feuerstein utilizou o conceito de processamento, organizando as FC em três fases fundamentais: entrada, elaboração e saída, entretanto destaca que as fases são interdependentes em uma redefinição constante do fluxo de processamento interno, podendo "modificar o nível de entrada, ou de elaboração, seja em termos de intensidade, de precisão ou de estratégias processuais". (GOMES, 2002, p. 113)

De maneira subsequente, podemos prever que o modelo das Funções Cognitivas proposto por Reuven Feuerstein et. al. (1980) possui relação direta com as ideias de Vigotski, ainda que o primeiro não tenha considerado ou tomado contato com as ideias e pressupostos defendidos pelo segundo, no sentido de que a mediação dos instrumentos simbólicos é fundamental para a reelaboração constante das funções psicológicas superiores. Feuerstein, porém, aprofunda em sua tese a questão central para que ocorra a modificação das FC, a importância da mediação humana, ou seja, a necessidade de um ser humano que medeie a relação entre o sujeito e o objeto de aprendizagem para que ocorra por meio de uma Experiência de Aprendizagem Mediada o desenvolvimento e novas aprendizagens.

Tendo em vista os referenciais teóricos da teoria da Experiência de Aprendizagem Mediada, da Filosofia da Linguagem e do pensamento complexo de Edgar Morin no contexto do desenvolvimento das competências leitora e escritora é que o planejamento e aplicação da 
Sequência Didática “O Brasil vai de quê?” por gêneros discursivo-textuais ocorreu em nossas aulas de Geografia na Escola Municipal de Ensino Fundamental General Alcides Gonçalves Etchegoyen, localizada no Jardim Arpoador, zona oeste da cidade de São Paulo, entre os meses de agosto e dezembro de 2013 , em três turmas de $7^{\circ}$ anos (A, B, C) ${ }^{42}$, envolvendo inicialmente 77 alunos frequentes em nossas aulas.

No quadro 5 apresentamos uma visão geral da organização e estrutura da SD:

Quadro 5 - Informações gerais sobre a Sequência Didática

\begin{tabular}{|c|c|c|c|}
\hline TÍTULO DA SEQUÊNCIA & \multicolumn{3}{|c|}{ O Brasil vai de quê? } \\
\hline QUESTÃO PROBLEMA & \multicolumn{3}{|c|}{$\begin{array}{l}\text { A exemplo de muitos países europeus com vasta } \\
\text { malha ferroviária é comum ouvir que a solução } \\
\text { para os problemas da rede de transportes no } \\
\text { Brasil são de investimentos neste modal. Seria } \\
\text { esta a solução para os problemas de transporte no } \\
\text { Brasil? }\end{array}$} \\
\hline ESCOLA & \multicolumn{3}{|c|}{$\begin{array}{l}\text { Emef General Alcides Gonçalves Etchegoyen - } \\
\text { São Paulo (SP) }\end{array}$} \\
\hline ANO/SÉRIE e PERÍODO & \multicolumn{3}{|c|}{$7^{\circ}$ ano $/ 6^{\mathrm{a}}$ série $-\mathrm{TARDE}$} \\
\hline $\begin{array}{l}\text { QUANTIDADE DE } \\
\text { AULAS PREVISTAS }\end{array}$ & \multicolumn{3}{|c|}{30} \\
\hline TURMAS & $\mathbf{A}$ & B & $\mathbf{C}$ \\
\hline $\begin{array}{l}\text { QUANTIDADE DE } \\
\text { ALUNOS (por turma) }\end{array}$ & 26 & 26 & 25 \\
\hline $\begin{array}{l}\text { QUANTIDADE DE } \\
\text { AULAS EFETIVAS (por } \\
\text { turma) }\end{array}$ & 48 & 51 & 48 \\
\hline GÊNERO DE DISCURSO & \multicolumn{3}{|c|}{ Acadêmico } \\
\hline GÊNERO DE TEXTO & \multicolumn{3}{|c|}{ Dissertação } \\
\hline $\begin{array}{l}\text { CAPACIDADE DE } \\
\text { LINGUAGEM }\end{array}$ & \multicolumn{3}{|c|}{ Argumentar } \\
\hline \multirow{7}{*}{$\begin{array}{l}\text { ESTRUTURA DOS } \\
\text { MÓDULOS }\end{array}$} & \multicolumn{3}{|c|}{$\begin{array}{l}\text { Módulo } 1-\text { "Articuladores sintáticos e tipos de } \\
\text { argumentos" }\end{array}$} \\
\hline & \multicolumn{3}{|c|}{ Elaboração textual intermediária } \\
\hline & \multicolumn{3}{|c|}{ Módulo 2: "Leitor crítico" } \\
\hline & \multicolumn{3}{|c|}{ Módulo 3: "Cartografia" } \\
\hline & \multicolumn{3}{|c|}{$\begin{array}{l}\text { Módulo 4: "Análise do setor de transportes no } \\
\text { Brasil e Debate Regrado" }\end{array}$} \\
\hline & \multicolumn{3}{|c|}{ Elaboração textual final } \\
\hline & \multicolumn{3}{|c|}{ Módulo 5: Leitor crítico } \\
\hline
\end{tabular}

Fonte: Elaboração Ketlin E. T. W. Fiocco.

${ }^{42}$ Em 2013 as turmas ainda estavam organizadas em séries, por este motivo, há documentos que aparecem $6^{\mathrm{a}}$ séries para as turmas que participaram da aplicação de Sequência Didática. No corpo do texto optamos por utilizar a atual denominação em anos, e por isso $7^{\circ}$ anos. 
Como critério para constituição do universo de amostras válidas da nossa pesquisa

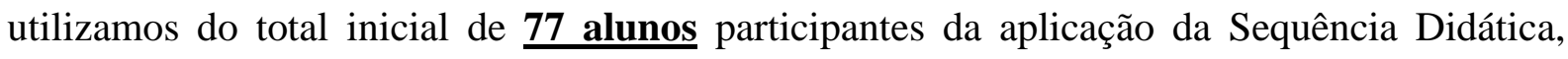
somente os alunos que elaboraram três textos, sendo um inicial, um intermediário e um final e que participaram ao menos de um dos turnos de Debate Regrado, como debatedor ou como

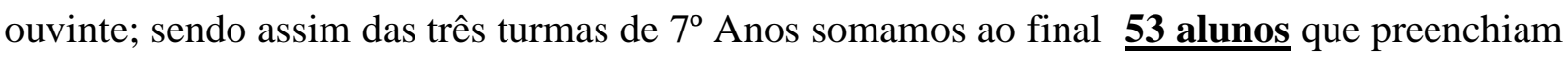
estes critérios. Entretanto ao longo de nossa análise também utilizamos os textos e as falas gravadas do número de alunos, que não possuíam as três dissertações e a participação no debate regrado, pois julgamos que, ainda que parcialmente, todos os alunos envolvidos participaram dos processos que pretendíamos compreender, relacionados à elaboração de conceitos e ao aprendizado de Geografia por meio de gêneros discursivo-textuais na relação entre as modalidades oral e escrita.

Gráfico 1 - Alunos frequentes e alunos com três produções textuais e participação do Debate Regrado.

\section{Alunos participantes das atividades da Sequência Didática "O Brasil vai de quê?"}

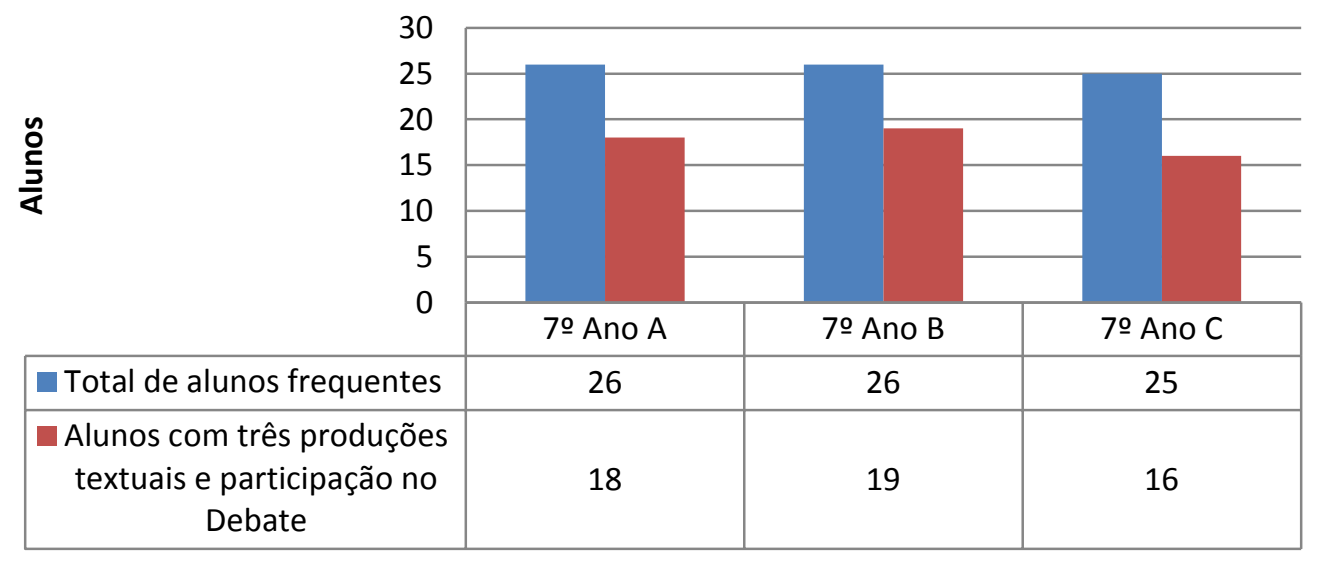

Fonte: Elaboração Ketlin E. T. W. Fiocco

Optamos por trabalhar com o número de alunos, de cada uma das três turmas, que efetivamente frequentaram nossas aulas e não com o número de alunos matriculados oficialmente, tentando assim nos aproximar do aprendizado dos alunos reais que chegam à escola e não daqueles que nem conseguem frequentar o ambiente escolar.

Os motivos que levam a discrepância da realidade entre os alunos matriculados e aqueles que efetivamente frequentam as aulas são diversos e não constituem objeto de nossa análise, mas julgamos importante destacar nossa opção para obtenção de dados mais próximos da realidade no enfoque de nossa pesquisa. 
Durante o processo de aplicação de SD os alunos elaboraram três produções textuais do gênero discursivo-textual dissertação e da esfera de ação acadêmica/escolar e participaram ao menos de um dos turnos de Debate Regrado, sendo que a quantidade de alunos que elaboraram cada uma das dissertações estão representadas no gráfico 2.

Gráfico 2 - Número de alunos de cada uma das elaborações textuais escritas e oral ao longo da aplicação de SD.

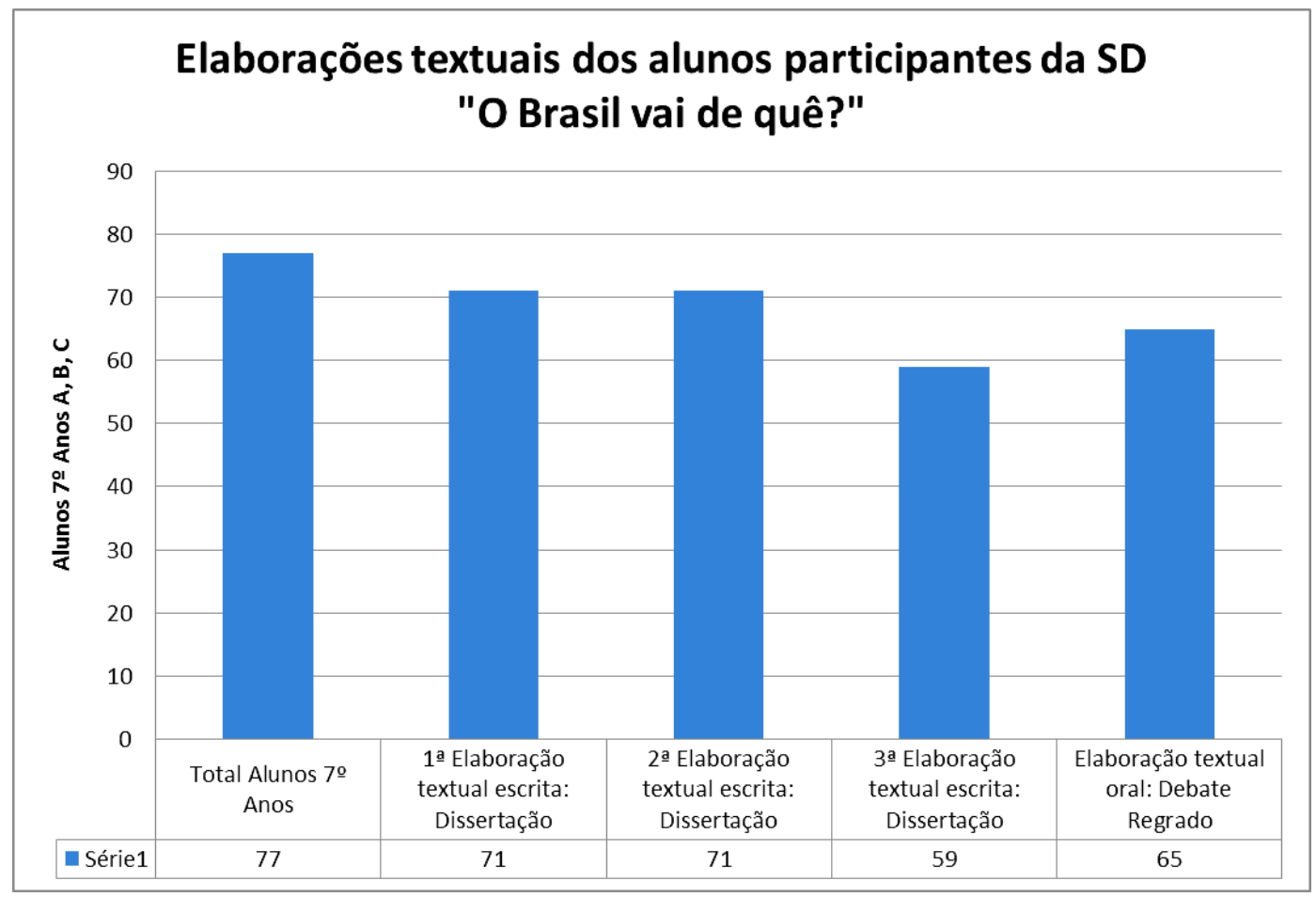

Fonte: Elaboração Ketlin E. T. W. Fiocco.

O número de alunos frequentes nas três turmas dos $7^{\circ}$ anos é 77 e, de uma maneira geral, há uma queda em relação ao número de alunos que iniciam o processo produzindo uma dissertação e dos que ao longo das atividades deixam de participar da elaboração dos textos orais e escritos, por motivos variados, ou ausentam-se no dia marcado para a atividade e, ainda que tenhamos promovido outras oportunidades aos alunos, não foi possível que todos concluíssem o processo de estudos da SD.

O processo de aplicação de SD já se iniciou com uma queda de $8 \%$ (6 alunos) que não elaboram a primeira dissertação escrita e a mesma proporção de alunos se repete ao compararmos os alunos que iniciaram o processo fazendo a dissertação inicial e aqueles que participaram do Debate Regrado (6 alunos). Quando comparamos somente os alunos que conseguiram iniciar e concluir a proposta de elaboração de três dissertações, temos uma queda maior ainda, de $17 \%$ (12 alunos). 
Ainda que não seja objeto de nossa análise podemos apontar algumas das dificuldades enfrentadas para que seja garantido o espaço efetivo de aulas. Tal espaço constantemente é ameaçado por atividades da própria escola que ocorrem sem planejamento anterior ou por intercorrências como falta de energia elétrica e água, mudanças nas datas de reuniões e o próprio calendário escolar que apesar de contar com aulas previstas para o mês de dezembro, por exemplo, não tem praticamente frequência de alunos, pois muitos deixam de comparecer, entre outros.

O gráfico 3 apresenta a proporção entre os alunos que elaboraram as três dissertações e participaram do Debate Regrado, 75\% (53 alunos) e os alunos que participaram da aplicação de SD, entretanto apresentaram atividades incompletas ou que não as realizaram, representando $25 \%$ (24 alunos).

Gráfico 3 - Proporção alunos participantes de todas as atividades da SD e alunos com atividades incompletas ou pendentes

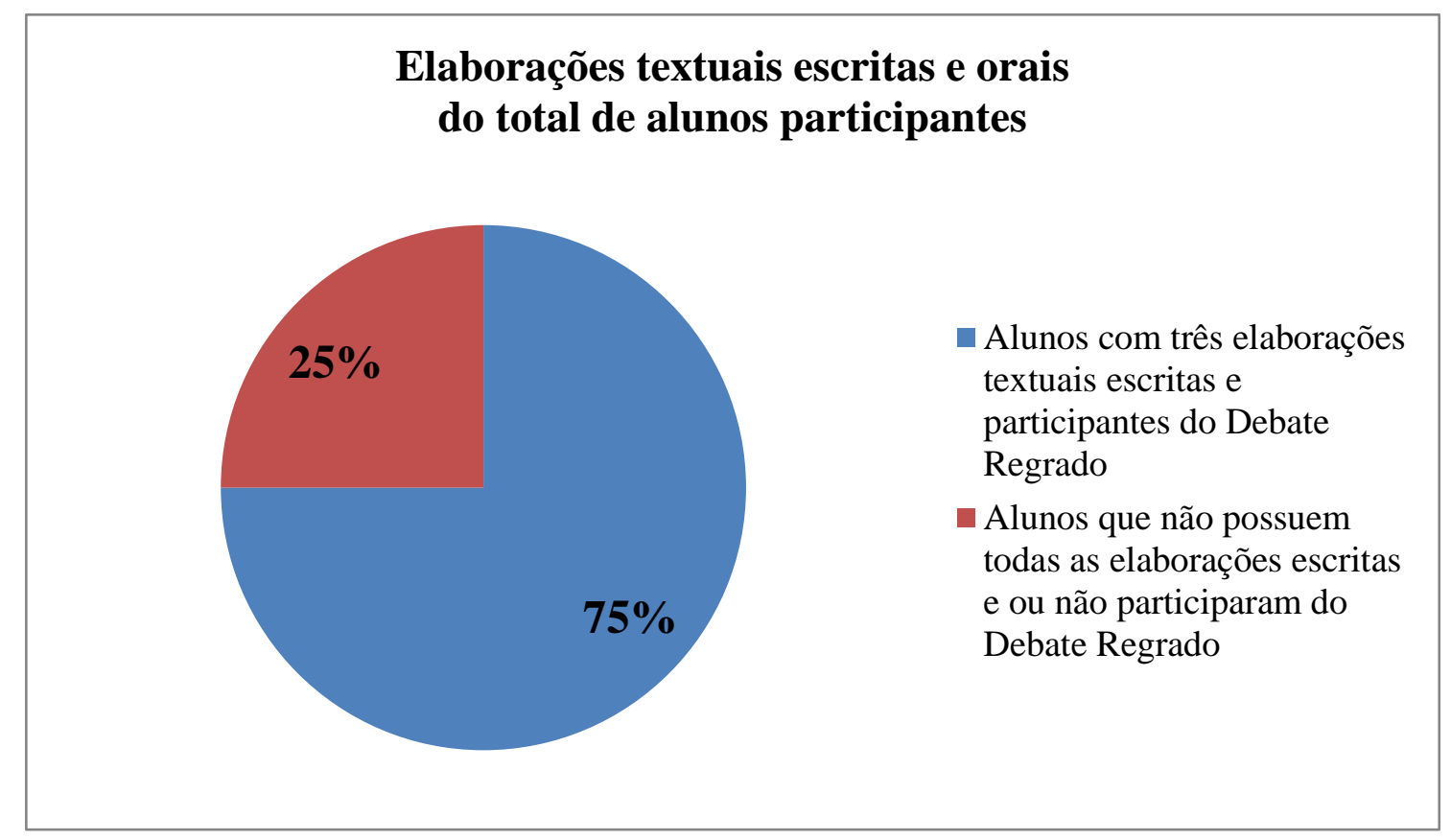

Fonte: Elaboração Ketlin E. T. W. Fiocco

As proporções do universo de nossa amostra apresentam dados que julgamos preocupantes de nossa realidade educacional, no que se refere ao número de alunos que, por diversos motivos, não participam de todas as oportunidades de aprendizagem a que têm direito.

Ainda não somos capazes de, enquanto sociedade e escola, por meio de mecanismos mais eficientes, garantir que todos os alunos consigam participar das atividades que são 
propostas nas aulas configurando um distanciamento entre o potencial de aprendizado e desenvolvimento das crianças, adolescentes e jovens e o que ocorre de fato ao longo da escolarização.

O incômodo com esse fato gera uma preocupação que nos leva a refletir sobre os aspectos de nossa própria prática que, de alguma maneira, podem ter contribuído para que, no caso desta pesquisa, $25 \%$ dos alunos não tenham conseguido concluir todas as atividades propostas no contexto de aplicação de uma SD; para além de uma análise negativa, acreditamos que trabalhos de pesquisa de professores podem oferecer, sobretudo, indicativos para a superação do problema na educação a que estamos referindo.

O desejo que expressamos aos alunos de que aprendessem e que fizessem efetivamente todas as atividades, considerando os critérios universais da mediação, segundo Reuven Feuerstein, a intencionalidade e a reciprocidade, compreendem também um exercício pessoal acerca da condição humana comum, em um contínuo gesto de acolhimento da diversidade cultural, que é inerente a tudo que é humano (MORIN, 2011, p. 42).

Se na prática docente, 24 alunos não conseguiram realizar todas as atividades previstas nos distanciando de nosso ideal, conjuntamente com os demais mecanismos e atores de nossa sociedade, que impedem a garantia do direito dos alunos de aprender a enunciar ideias, ou seja, elaborar discursos e elaborar conceitos, ao menos em nossa análise no plano teórico, nos comprometemos em acolher os enunciados dos alunos como sujeitos discursivos e assim para além do desenvolvimento de competências leitora e escritora, pensar a escola como espaço de conhecimento e de acolhimento e, por conseguinte de formação de sujeitos.

O movimento entre nosso trabalho como docente na escola pública com 77 alunos, que se constituiu em nosso campo de pesquisa e o trabalho de análise dos 159 textos e pouco mais de 3 horas de gravações audiovisuais, bem como o processo de elaboração de nosso próprio texto, se deu em torno de dois grandes conceitos, segundo Bakhtin: alteridade e cronotopos ${ }^{43}$, que apreendemos do trabalho de Marília Amorim em sua obra "O pesquisador e seu outro" (AMORIM, 2004, p.209):

À semelhança do que acontece no campo, durante o trabalho de escrita, um saber se constrói e novas descobertas são feitas na e pela gestão e reflexão da relação com o outro. Trata-se então, aqui de uma análise da relação com o outro segundo o modo como ele é representado no texto. (...) pensamos com Bakhtin que o sentido da representação é sempre algo a construir e reconstruir segundo as leituras que se faz do texto.

As Ciências Humanas, quando não são apenas teóricas, têm como cronotopos principal o campo. O campo é o todo inteligível e concreto pelo

\footnotetext{
43 “O cronotopos é a materialização do tempo no espaço: há um lugar em que a história se desenrola, o tempo passa, se vive e se mede em função das características desse lugar”. (AMORIM, 2004, P.222-223)
} 
qual as relações espácio temporais da pesquisa se definem. Organizado sob a forma de diferenças práticas, o campo oferece ao pesquisador a possibilidade de que o encontro com o outro se dê de modo sistemático. Sistemático e não aleatório, em função das próprias práticas e das restrições espácio temporais que se impõem ao pesquisador.

Os limites que tivemos que impor ao focalizarmos a análise da oralidade enquanto gênero discursivo-textual nas aulas de Geografia e no contexto de uma aplicação de SD na escola pública, ou seja, em nosso cronotopos, não impediu de enfrentarmos a complexidade da alteridade e de reencontrarmos muitas e muitas vezes com as vozes dos nossos alunos e com a nossa própria voz numa busca incessante de construção de sentidos e por definição, inacabável (AMORIM, 2004, p. 19).

Bourdieu (2012, p. 9) na introdução da obra "A miséria do mundo", apresenta como sociólogo sua preocupação e cuidado com os sujeitos de sua pesquisa, que se assemelha ao nosso cuidado de professora ao apresentarmos a análise dos textos dos nossos alunos:

Entregamos aqui os depoimentos que homens e mulheres nos confiaram a propósito de sua existência e de sua dificuldade de viver. Organizamo-los e os apresentamos com o objetivo de conseguir do leitor que lhes conceda um olhar tão compreensivo quanto o que as exigências do método científico nos impõem e nos permite conceder-lhes. É por isto que esperamos que ele concordará em acompanhar o caminho proposto.

Da mesma forma compartilhamos aqui os enunciados dos nossos alunos, adolescentes, estudantes da escola pública em desenvolvimento biopsicossocial em processo de aprendizagem em um recorte do contexto da escolarização das aulas de Geografia do $7^{\circ}$ Ano do Ensino Fundamental, do ano de 2013. Sem eximirmos das críticas de nossa ação e reflexão e dos nossos próprios enunciados presentes na polifonia de vozes é que o realizamos e apresentamos por meio das análises desta pesquisa de Mestrado.

\subsection{A oralidade como elemento para a formação de sujeitos na aula de Geografia}

Desde o início da nossa pesquisa nos deparamos com o dilema de refletir e delinear a complexa concepção de sujeito imbricada em uma proposta de Ensino de Geografia por meio das elaborações textuais orais e escritas dos alunos da Educação Básica e da escola pública com a consequente valorização dos enunciados dos alunos envolvidos.

Consideramos como dilema trabalharmos com a concepção de sujeito, pois sem dúvida a tarefa envolve concepções de cunho filosófico e sociológico, além de nossas próprias 
crenças e da compreensão de que, sem o enfrentamento desta questão, não seria possível sustentar uma proposta de Ensino de Geografia por gêneros discursivo-textuais.

A concepção de sujeito imbricada na proposta teórica e metodológica envolvida nesta pesquisa se afirma como um contraponto ao tratamento massificado de políticas públicas de educação que visam resultados, por meio de propostas que desconsideram o complexo processo de desenvolvimento e aprendizagem, bem como a necessidade de valorização e acolhimento dos enunciados dos alunos em permanente construção.

Entendemos que os processos de desenvolvimento e aprendizagem de cada um dos alunos presentes em nossas aulas, além de distintos, são ao mesmo tempo imbricados e o professor tem papel preponderante na organização e realização das interações mediadas conforme a Teoria da Experiência da Aprendizagem Mediada (EAM) de Feuerstein, e na avaliação do aluno por meio de critérios que privilegiem o próprio processo de aprendizagem do sujeito.

Como parte de nossa pesquisa e reflexão organizamos um artigo denominado "O sujeito discursivo na aula de Geografia" (FIOCCO, 2013) ${ }^{44}$ em que apresentamos as ideias iniciais acerca da concepção de sujeito, no XIV Encontro de Geógrafos da América Latina, em Lima, Peru no ano de 2013.

Neste artigo articulamos as ideias, entre outras, de Edgar Morin (2002, p. 127) de que "uma concepção complexa de sujeito significa reconhecer que, potencialmente, todo sujeito é não apenas ator, mas autor, capaz de cognição/escolha/decisão" e de Alain Touraine (1994, p.298-290) em que afirma:

Nada nos pode afastar de nossa afirmação central: o sujeito é um movimento social. Ele não se constitui na consciência de Si-mesmo, mas na luta contra o anti-sujeito, contra as lógicas de aparelho, principalmente quando estas se tornam indústrias culturais e, a fortiori, quando elas possuem objetivos totalitários. (grifos do autor)

As ideias destes dois autores nos apoiaram na apresentação de referenciais e argumentos que rompem com a lógica do ensino de uma Ciência Morta ${ }^{45}$, ou seja, práticas

\footnotetext{
${ }^{44}$ FIOCCO, K.E.T.W. O sujeito discursivo na aula de Geografia. In: 14 Encuentro de Geógrafos de América Latina, 2013. Anais (ISBN: 9786124640728). Lima: IGU/UGI. v. Único. Disponível em: http://www.observatoriogeograficoamericalatina.org.mx/egal14/Ensenanzadelageografia/Investigacionydesarroll oeducativo/23.pdf Acesso em 21 abr. 2016.

${ }^{44}$ Utilizamos os conceitos de Ciência Viva/Ciência Morta e como referência apoiamo-nos em dois cientistas, o físico Sébastien Balibar (2012) e o astrofísico Carl Sagan (1980), em que apontam à necessidade de se ensinar às crianças a ciência viva através das questões que a própria ciência ainda não tem as respostas.
} 
didáticas que reforçam a reprodução de informações e ideias aceitas como verdades imutáveis presentes sobretudo em livros didáticos que distanciam a formação do sujeito autor que Morin se refere e das demandas contemporâneas de nossa sociedade.

As ideias de Morin (2002) colocam em xeque uma concepção de sujeito, partindo não da afetividade, não do sentimento, mas de uma base bio-lógica, no sentido da lógica própria do ser vivo (Varela, 2007, p. 21) que ocorre na relação entre os indivíduos e o meio em que vivem, a fim de encontrar elementos para a sobrevivência enquanto, simultaneamente, organismo e ser cultural. $\mathrm{O}$ autor reconhece que não existe uma autonomia totalmente livre do ser humano, pois enquanto ser social e cultural necessita desenvolver uma dependência original em relação à cultura, à língua e a um saber (MORIN, 2002, p.118).

Até então a concepção complexa de sujeito proposta por Morin se aproximava da perspectiva sociocultural adotada por nós em que a relação do sujeito com os instrumentos simbólicos de nossa cultura propiciam um novo tipo de desenvolvimento, sendo a interação social fundamental neste processo. Identificamos que existe uma relação do ponto de vista da importância do contexto social e cultural para o desenvolvimento do sujeito, entre a ideia de dependência original do indivíduo enquanto organismo e ser cultural de Morin e a concepção de sujeito de Touraine como movimento social, quando afirma que:

$\mathrm{O}$ sujeito se forma na vontade de escapar às forças, às regras, aos poderes que nos impedem de sermos nós mesmos, que procuram reduzir-nos ao estado de componente de seu sistema e de seu controle sobre a atividade, as intenções e as interações de todos. Essas lutas contra o que nos rouba o sentido de nossa existência são sempre lutas desiguais contra um poder, contra uma ordem. Não há um sujeito senão rebelde, dividido entre raiva e esperança. (TOURAINE, 2011a, p. 119)

Nas duas citações do sociólogo Alain Touraine pode-se observar o enfoque da constituição do sujeito no contexto social, entretanto, ao aprofundarmos os estudos no deparamos com a sua tese em que afirma que o sujeito social está destruído. Inicialmente tendemos a acreditar que o autor parecia se contradizer ao utilizar-se da expressão "fim do social", entretanto, ao explicar que o triunfo dos critérios econômicos sobre os critérios políticos na organização da vida em sociedade já não são mais suficientes para explicar ou definir os atuais problemas e demandas contemporâneas, sobretudo de cunho cultural (TOURAINE, 2011a, p. 239), nos fizeram observar e refletir sobre a escola e a formação de sujeitos de um outro modo. O próprio autor explica a utilização da expressão:

(...) Esta expressão "fim do social" pode parecer excessiva, mas ela não é menos imprópria do que era o fato de falar no século XVIII, de "sociedade industrial", quando a atividade agrícola ainda exercia uma função importante. (...) uma vez superado o choque produzido por esta expressão, 
ela nos ajuda a compreender a amplitude das transformações que se operam (...) o ponto essencial aqui, como já o dissemos, é reconhecer que os atores não são mais motivados por seus interesses sociais e econômicos, mas pela vontade de defender seus direitos, isto é, de fundar seu desejo de liberdade e de justiça sobre a consciência de carregar em si mesmos o sujeito humano. (TOURAINE, 2011b, p.141)

Touraine (2011) afirma que novas categorias sociais precisam ser pensadas para o atual momento, sendo um dos critérios a questão cultural inaugurando assim, uma reflexão sobre os indivíduos e não mais sobre a realidade social. De acordo com o autor:

Hoje, dois séculos após o triunfo da economia sobre a política, estas categorias "sociais" tornaram-se confusas e deixam na sombra uma grande parte de nossa experiência vivida. Precisamos, portanto, de um novo paradigma, pois não podemos voltar ao paradigma político, sobretudo porque os problemas culturais adquiriram tal importância que o pensamento social deve organizar-se ao redor deles. (TOURAINE, 2011a, p.9, grifo do autor)

No relatório que elaboramos para o exame de qualificação do Mestrado apresentamos um esquema (Figura 3) que nos ajudou a compreender os paradigmas e a concepção de sujeito que Touraine se referiu, a partir da análise dos critérios que organizavam as sociedades em determinado tempo e espaço. 
Figura 3 - Categorias de análise das realidades sociais

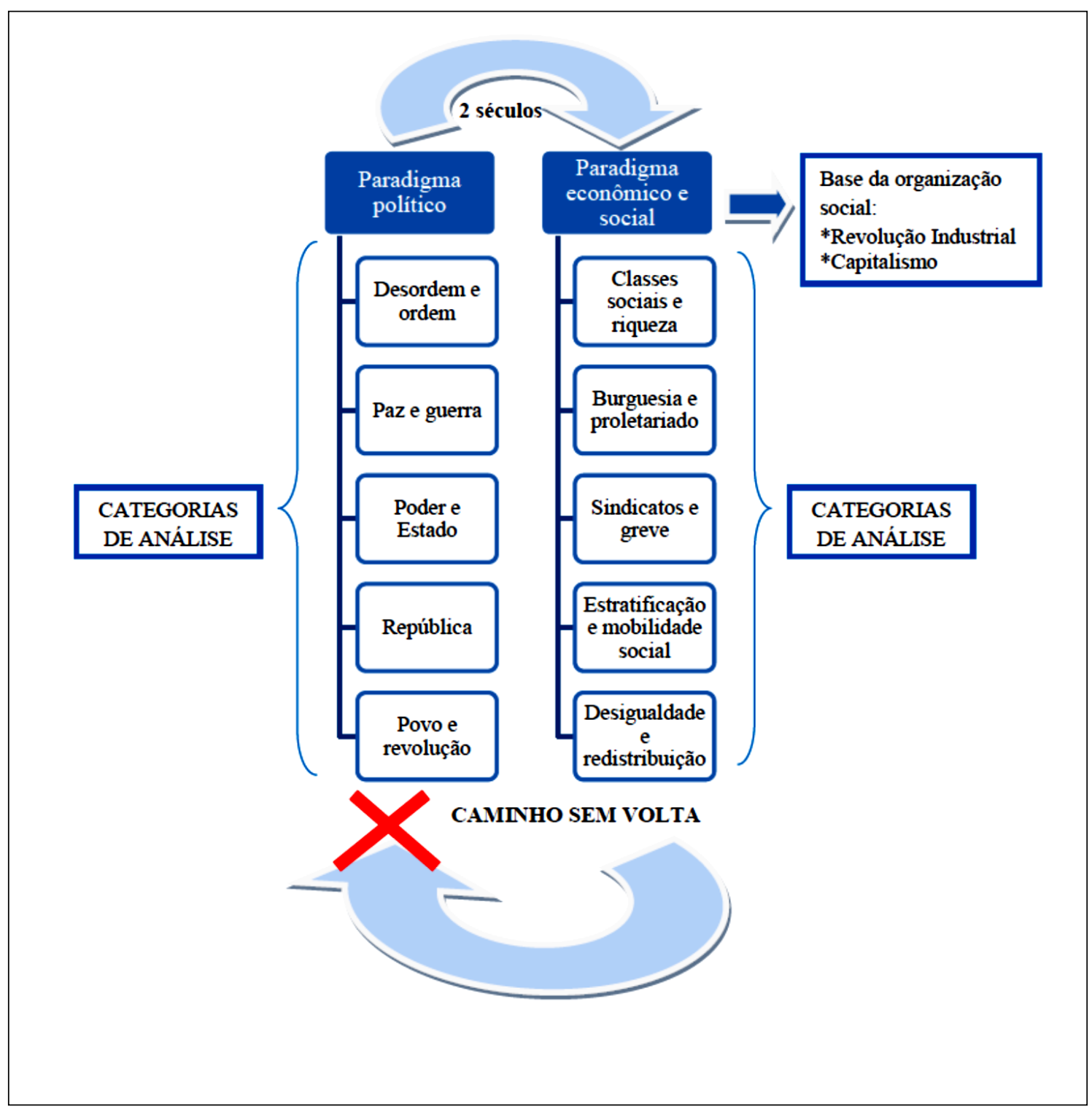

Fonte: Touraine (2011). Elaboração Ketlin E. T. W. Fiocco.

Como em nosso esquema contemplamos apenas os paradigmas políticos e socioeconômicos nos propusemos a identificar, ainda que incipientemente e do ponto de vista da escola pública da Rede do Município de São Paulo, as transformações das relações entre os indivíduos e os aspectos da organização social que fazem emergir um novo paradigma, ou seja, aquilo que está no princípio da construção das teorias, ou o núcleo ainda obscuro que orienta os discursos teóricos neste ou naquele sentido (Morin, 1999, p.45) em que pese ainda se apresentar sem respostas práticas aos desafios contemporâneos é preciso acolhê-lo neste tempo de indefinições e de transição, que Bauman (2011, p. 146) denomina de interregnum, e como afirma Touraine (2011a, p.11): 
Cada vez que muda nosso olhar sobre nós mesmos, nosso meio ambiente e nossa história, temos a impressão de que o antigo mundo ruiu por terra e que não aparece nada capaz de substituí-lo. É o que experimentamos hoje, mas como fizemos no passado o tentaremos construir uma nova representação da vida social e escapar assim à impressão angustiante da perda total de sentido.

Experimentamos em nossas escolas o que Touraine (2011a) chama de perda de sentido, antes de uma escola transmissora de conteúdos para a realidade que os relatos de indisciplina, violência, analfabetismo e desinteresse dos alunos podem nos revelar, principalmente quando nossas opções metodológicas de ensino se baseiam em critérios que não correspondem mais às atuais exigências para a formação complexa de sujeitos.

É na escola, por meio das relações com as novas gerações de adolescentes e jovens, que representam tão intensamente as buscas por novas respostas aos desafios da construção de sentido e visão de mundo para um novo paradigma cultural que, por meio de conflitos e diálogos, o sujeito se desenvolve.

Entre as categorias do novo paradigma cultural, que gostaríamos de apontar a partir de Touraine (2011a), estão os atributos particulares dos indivíduos, como a liberdade e a criatividade, que exigem da escola uma transformação de instituição de socialização para um sistema que apoie e sustente as novas representações do eu e das coletividades que venham a surgir.

Outra categoria do novo paradigma cultural e que identificamos na escola, é a revolução tecnológica, cujos efeitos podem ser percebidos na maneira como os alunos se comunicam e se relacionam com a velocidade das informações e com o mundo virtual.

Consideramos, assim como Touraine (2011a, p.12) que mais importante do que identificar categorias é considerar o momento de passagem entre um paradigma e outro, principalmente quanto às mudanças "de uma relação direta do sujeito consigo mesmo, sem passar pelas intermediações metassociais que pertencem ao campo da filosofia da história”.

No critério das novas relações diretas do sujeito consigo mesmo em contrapartida às intermediações que colocavam o sujeito em uma posição de passividade frente a conceitos e ideias vigentes e de organização da sociedade, consideramos fazer uma ressalva, quando estamos tratando da formação de sujeitos na escola, quanto à necessidade da mediação humana intencional dos instrumentos simbólicos de nossa cultura, para que os alunos possam alcançar ao longo do seu desenvolvimento a autonomia na construção de sua identidade e de sua coletividade, sobretudo no exercício de seus "direitos culturais" (TOURAINE, 2011a, p.13) como sujeitos e neste aspecto o professor tem papel fundamental. 
Para a compreensão do papel fundamental do professor na mediação humana e bem como o momento de desenvolvimento e aprendizagem dos alunos da Educação Básica retomamos a complexa concepção de sujeito em que Morin destaca a dimensão cognitiva:

(...) é preciso pensar que toda organização biológica necessita de uma dimensão cognitiva. (...) Da mesma maneira, o ser vivo (...) retira informações de seu meio ambiente e exerce uma atividade cognitiva inseparável de sua prática de ser vivo. Ou seja, a dimensão cognitiva é indispensável à vida. (MORIN, 2002, p. 119)

A ideia do sujeito como indivíduo biológico nos faz buscar uma compreensão maior sobre o processo de desenvolvimento das estruturas cognitivas e para os aprendizados que vão ocorrendo especialmente ao longo dos anos de escolarização por meio das interações que ocorrem no espaço da escola e das aulas. Como afirma Piaget (1976, p.17-18) a qualidade do que é inato consiste essencialmente nas possibilidades de funcionamento e não na hereditariedade de estruturas organizadas de antemão.

Dessa forma a escola e especialmente as aulas se apresentam como possibilidade de funcionamento e estruturação do pensamento e da dimensão cognitiva indispensável à formação de sujeitos que podem cada vez mais criar relações de dependências criativas com a cultura em que estão inseridos por meio de interações mediadas.

Articulamos a possibilidade de mediação do funcionamento e estruturação do pensamento às novas demandas do paradigma cultural, no sentido de reconhecer todo o potencial e os "sinais de propensão para mudança" (Feuerstein, 2002, p.14) dos alunos da Educação Básica.

Feuerstein et. al. (2002) elaborou a sua Teoria da Modificabilidade Cognitiva Estrutural acreditando e comprovando seu sistema de crenças com a pesquisa que realizou com crianças vítimas do holocausto da II Guerra Mundial (1939-1945) a qual lhe exigiu uma mudança no ponto de vista da compreensão do desenvolvimento e aprendizagem, da fixidez e da imutabilidade, para a capacidade de modificabilidade cognitiva, emocional ou comportamental dos sujeitos.

Feuerstein (2002), afirma que só tornou plausível sua teoria a partir de três pressupostos: a ontogenia biológica, a ontogenia sociocultural e a relação constante entre estas duas ontogenias que constituem os seres humanos.

A ontogenia biológica consiste em "perceber o ser humano como uma comunidade de células interagindo agitadamente entre si e com o ambiente" (Feuerstein, 2002, p. 15). 
A ontogenia sociocultural diz respeito a "estrutura moral e comunicacional do ser humano. É essa parte do desenvolvimento que dá ao organismo a verdadeira natureza de entidade humana" (Feuerstein apud. Gomes, 2002, p. 15).

Considerando apenas estas duas ontogenias, nossas escolas poderiam ser transformadas pela consciência de sujeitos diferentes que seriam tratados minimamente com maior respeito quanto ao direito de aprender e se desenvolver, sendo na primeira, a visão de organismos biológicos e na segunda de indivíduos socioculturais, que de maneira articulada por meio da interação cultural, ambas colaboram para a formação de sujeitos.

Acontece que as ontogenias tanto biológicas, quanto sociocultural estão em constante “interação estressante, contínua e altamente conflituosa” (Feuerstein apud. Gomes, 2002, p. 15) e que tal relação pode ser assim explicada:

A entidade biológica certamente impõe limites e os traz à tona, ao mesmo tempo em que a ontogenia sociocultural luta por libertar o ser humano desses limites, modificando e criando novos rumos de vida, apesar da imposição, mas contra tal imposição da realidade biológica, neurológica e cromossômica.

Diante da complexidade da concepção de sujeito autor, capaz de cognição/escolha/decisão, no movimento constante de reinvindicação de ser sujeito resistindo às dominações das coisas, das técnicas e das linguagens difundidas massivamente (Touraine, 1994, p.277) e na interação estressante, contínua e conflituosa das ontogenias biológica e socioculturais no contexto de um novo paradigma cultural é que nossos alunos estão na escola, produzindo enunciados que podem revelar novas formas de pensar, de compreender o mundo em que vivemos e construir dialogicamente novos conhecimentos.

Se estamos vivendo o interregnum da passagem de um paradigma social pautado em critérios socioeconômicos para um novo paradigma pautado em critérios culturais, a escola pode se tornar espaço para a elaboração de ações que contribuam para o desenvolvimento de pensamentos de tipo mais complexo e de níveis mais abstratos tendo como ponto de partida os enunciados e, por conseguinte, os discursos e com eles, os alunos dialogar.

Partindo desta possibilidade, a escola e principalmente, o professor reencontra o seu papel na sociedade por meio da formação de sujeitos discursivos, capazes de comunicar suas ideias e formas de pensar de maneira mais competente, real e consciente das forças que nos impedem de sermos nós mesmos. (TOURAINE, 2011a, p. 119).

Um sujeito discursivo dialoga todo o tempo considerando os enunciados, ou seja, os outros sujeitos discursivos, "por sua precisão e simplicidade, o diálogo é a forma clássica de comunicação discursiva" (Bakhtin, 2010, p.275) e, assim compreendido, o diálogo torna-se 
fundamental "na corrente complexamente organizada de outros enunciados" (Bakhtin, 2010, p.272).

Nesta corrente comunicacional compreendemos os enunciados dos sujeitos discursivos envolvidos, segundo Bakhtin (2010, p.271) como objetivo real da comunicação, e entendemos assim que não há como contribuir para a formação de sujeitos sem o pensamento complexo, cujos discursos, enunciados e textos sejam de natureza ativamente responsiva e contextualizada.

Diante de todos esses referenciais teóricos acerca da importância de se considerar o enunciado elaborado pelos sujeitos discursivos em suas práticas dialógicas de linguagem, encerramos esta etapa reiterando a importância do professor enquanto mediador, por excelência, do processo de ensino e aprendizagem do conhecimento científico na escola e na sala de aula como seu espaço mais íntimo e culturalmente impetrante. E desta forma, comprovamos em nossa rotina de pesquisa que os alunos gradativamente assumem, primeiramente para si e logo após para o meio cultural que os cerca, uma nova forma de ser e de enxergar os processos circunscritos em suas práticas dialógicas, fazendo-nos acreditar incessantemente no poder da ação docente para a modificação dos sujeitos, tendo em vista os seus textos escritos e a evolução de seus planos de argumentação, como expressão de sua oralidade. 


\section{Capítulo 3. Da oralidade com o pensamento espontâneo à oralidade com a leitura e a escrita: o desafio da oralidade como gênero discursivo-textual na aula de Geografia}

Aqui buscamos as possíveis relações do movimento que se depreende entre a oralidade e o aprendizado de conceitos próprios da Geografia pelos alunos e as possíveis contribuições da própria ciência geográfica enquanto disciplina do currículo escolar para o desenvolvimento das competências leitora e escritora.

$\mathrm{Na}$ organização da amostra do nosso trabalho procuramos identificar os gêneros discursivo-textuais utilizando os mesmos critérios da análise crítica que realizamos na primeira etapa da nossa pesquisa sobre os documentos da Rede de Educação do município de São Paulo: Referencial de Expectativas para o Desenvolvimento da Competência Leitora e Escritora no ciclo II do Ensino Fundamental II, e do Caderno de Orientações Didáticas de Geografia. Decidimos considerar na análise o gênero textual nas modalidades "oral”, "escrita", "simbólica" e "outras" com o objetivo de privilegiarmos a identificação, sobretudo, da modalidade oral em nosso próprio trabalho.

Elaboramos novos quadros identificando os gêneros a partir das atividades planejadas na SD para os alunos e que estão sintetizadas no quadro 6:

Quadro 6 - Gêneros discursivo-textuais na SD "O Brasil vai de quê"

\begin{tabular}{|c|c|c|c|c|c|c|c|c|}
\hline \multicolumn{9}{|c|}{$\begin{array}{c}\text { CLASSIFICAÇÃO DOS GÊNEROS DISCURSIVO-TEXTUAIS } \\
\text { DA SD "O BRASIL VAI DE QUÊ" }\end{array}$} \\
\hline \multirow{2}{*}{$\begin{array}{c}\text { MÓDU- } \\
\text { LO SD } \\
\text { O } \\
\text { BRASIL } \\
\text { VAI DE } \\
\text { QUÊ? }\end{array}$} & \multirow{2}{*}{$\begin{array}{c}\text { ESFERA } \\
\text { DE } \\
\text { AÇÃO/ } \\
\text { DOMÍ- } \\
\text { NIO } \\
\text { DISCUR } \\
\text {-SIVO }\end{array}$} & \multirow{2}{*}{$\begin{array}{c}\text { GENÊRO } \\
\text { DISCURSIVO } \\
\text { TEXTUAL }\end{array}$} & \multicolumn{2}{|c|}{$\begin{array}{l}\text { MODALI- } \\
\text { DADE } \\
\text { VERBAL }\end{array}$} & \multicolumn{2}{|c|}{$\begin{array}{c}\text { OUTRAS } \\
\text { MODALI- } \\
\text { DADES }\end{array}$} & \multicolumn{2}{|c|}{$\begin{array}{l}\text { USO DO } \\
\text { GÊNERO }\end{array}$} \\
\hline & & & ORAL & $\begin{array}{c}\text { ES- } \\
\text { CRI- } \\
\text { TA }\end{array}$ & $\begin{array}{l}\text { SIM- } \\
\text { BóLI } \\
\text { CA }\end{array}$ & $\begin{array}{l}\text { OU- } \\
\text { TRAS }\end{array}$ & $\begin{array}{l}\text { RECUR } \\
\text {-SO }\end{array}$ & $\begin{array}{l}\text { PRO- } \\
\text { DUTO }\end{array}$ \\
\hline \multirow{5}{*}{$\begin{array}{l}\text { Leitor } \\
\text { crítico }\end{array}$} & \multirow{5}{*}{$\begin{array}{l}\text { Escolar/ } \\
\text { Acadêmi- } \\
\text { co }\end{array}$} & $\begin{array}{l}\text { Ensino: Oito } \\
\text { perguntas e respostas }\end{array}$ & & 1 & & & 1 & \\
\hline & & Discussão & 1 & & & & 1 & \\
\hline & & Apresentação oral & 1 & & & & 1 & \\
\hline & & Ensino: Problema SD & & 1 & & & 1 & \\
\hline & & Dissertação & & 1 & & & & 1 \\
\hline
\end{tabular}




\begin{tabular}{|c|c|c|c|c|c|c|c|c|}
\hline & & $\begin{array}{l}\text { Ensino: Grade de } \\
\text { correção para a } \\
\text { avaliação das } \\
\text { dissertações }\end{array}$ & & 1 & 1 & & 1 & \\
\hline & & $\begin{array}{l}\text { Ensino: } \\
\text { recomendações ao } \\
\text { colega sobre sua } \\
\text { dissertação. }\end{array}$ & & 1 & & & & 1 \\
\hline \multicolumn{2}{|c|}{ Totais MÓDULO } & 7 & 2 & 5 & 1 & $\mathbf{0}$ & 5 & 2 \\
\hline \multirow{6}{*}{1} & \multirow{6}{*}{$\begin{array}{l}\text { Escolar/ } \\
\text { Acadêmi- } \\
\quad \text { co }\end{array}$} & Dissertação & & 1 & & & 1 & \\
\hline & & Quadro/Tabela & & 1 & 1 & & 1 & \\
\hline & & Ensino - Lista & & 1 & & & & 1 \\
\hline & & $\begin{array}{l}\text { Ensino - Resposta } \\
\text { para uma questão }\end{array}$ & & 1 & & & & 1 \\
\hline & & Comentário & & 1 & & & & 1 \\
\hline & & Apresentação oral & 1 & & & & & 1 \\
\hline \multicolumn{2}{|c|}{ Totais MÓDULO } & 6 & 1 & 5 & 1 & $\mathbf{0}$ & 2 & 4 \\
\hline \multirow{7}{*}{3} & \multirow{7}{*}{$\begin{array}{c}\text { Escolar/ } \\
\text { Acadêmi- } \\
\text { co }\end{array}$} & Mapa & & 1 & 1 & & 1 & \\
\hline & & Lista & & 1 & & & & 1 \\
\hline & & Quadro/Tabela & & 1 & 1 & & & 1 \\
\hline & & Comentário & & 1 & & & & 1 \\
\hline & & Apresentação oral & 1 & & & & & 1 \\
\hline & & Dissertação & & 1 & & & 1 & \\
\hline & & $\begin{array}{l}\text { Ensino - Registro no } \\
\text { caderno }\end{array}$ & & 1 & & & & 1 \\
\hline \multicolumn{2}{|c|}{ Totais MÓDULO } & 7 & 1 & 5 & 2 & $\mathbf{0}$ & 2 & 5 \\
\hline \multirow{8}{*}{4} & \multirow{8}{*}{$\begin{array}{c}\text { Escolar/ } \\
\text { Acadê- } \\
\text { mico }\end{array}$} & Dissertação & & 1 & & & 1 & \\
\hline & & Quadro/Tabela & & 1 & 1 & & 1 & \\
\hline & & Lista & & 1 & & & & 1 \\
\hline & & $\begin{array}{l}\text { Ensino - Registro no } \\
\text { caderno }\end{array}$ & & 1 & & & & 1 \\
\hline & & $\begin{array}{l}\text { Ensino - elaboração } \\
\text { de perguntas orais }\end{array}$ & 1 & & & & & 1 \\
\hline & & Comentário & & 1 & & & & 1 \\
\hline & & Apresentação oral & 1 & & & & & 1 \\
\hline & & Debate regrado & 1 & & & & & 1 \\
\hline \multicolumn{2}{|c|}{ Totais MÓDULO } & 8 & 3 & 5 & 1 & $\mathbf{0}$ & 2 & 6 \\
\hline \multicolumn{2}{|c|}{ Totais SD } & 28 & 7 & 21 & 5 & $\mathbf{0}$ & 11 & 17 \\
\hline
\end{tabular}

Fonte - Elaboração Ketlin E. T. W. Fiocco. 
A primeira análise foi identificar, entre os gêneros textuais planejados, a modalidade predominante, sendo que do total de 28 diferentes gêneros previstos, $25 \%$ de gêneros da modalidade oral e $75 \%$ de textos na modalidade escrita.

Gráfico 4 - Proporção de gêneros textuais escritos e orais planejados para a SD "O Brasil vai de quê?"

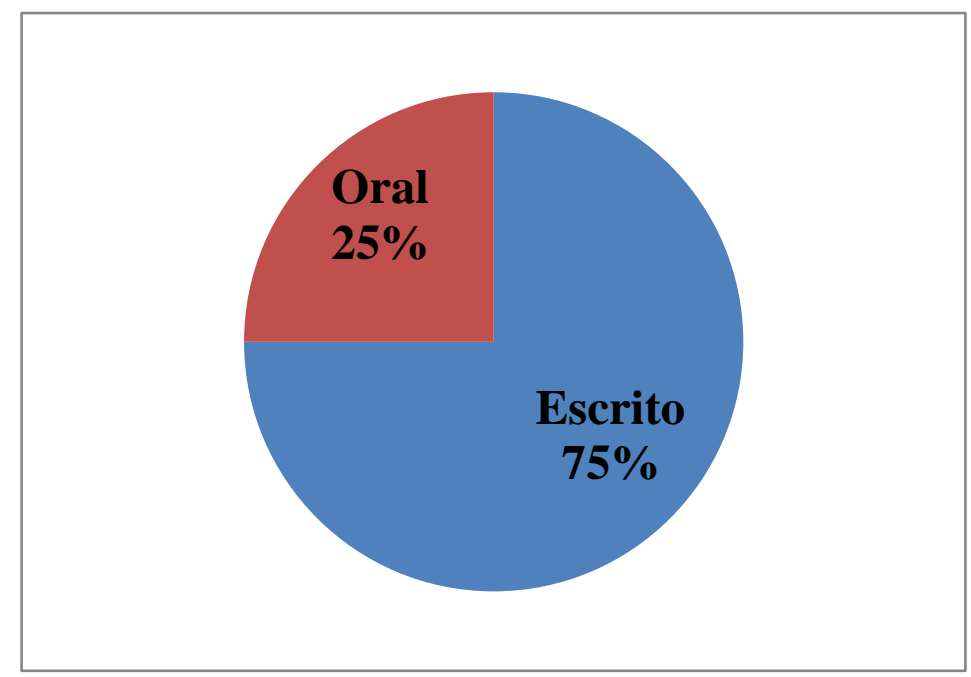

Fonte - Elaboração Ketlin E. T. W. Fiocco

Estes dados nos indicam dois aspectos que podem apoiar planejamentos de SD futuros, sendo o primeiro a diversidade de gêneros que foram previstos com o objetivo de apoiar a elaboração de conceitos e discursos pelos alunos que ao longo do processo de aplicação de SD foram materializados em texto nas modalidades escrita e oral.

Sobre o aspecto da diversidade de gêneros discursivo-textuais podemos considerar enriquecedora, no sentido de oferecer aos alunos uma gama de discursos, informações e instrumentos de comunicação que caso contrário, provavelmente não teriam acesso, como Dolz (2015) afirma que a diversidade de gêneros favorece o aprendizado. Ao mesmo tempo, a utilização demasiada de diferentes gêneros pode levar a um tratamento superficial dos elementos estáveis, das discussões e reflexões, como por exemplo, as intenções do autor ao apresentar determinadas ideias.

O segundo aspecto que destacamos é o predomínio de gêneros planejados da modalidade escrita sobre a modalidade oral, que pode indicar o valor e a importância que recebem cada uma das modalidades, oral e escrita que circulam na escola, na formação de professores e na sociedade, portanto na prática docente.

Entretanto, sabendo-se que a comunicação, a interação social e o próprio gênero aula envolvem constantemente a linguagem oral, provavelmente estes números seriam diferentes, 
nos indicando a necessidade de reconsiderar no trabalho didático, o gênero oral como objeto que deve ser planejado no ensino, a partir de seus elementos estáveis, além das necessidades imediatas do cotidiano rompendo assim com seu uso somente espontâneo.

Assim como Costa (2009), Rockwell (2012, p. 509) baseado em Bakhtin considera que a aula pode ser considerada como um gênero secundário ou multigenérico, ou seja, que combina uma variedade de gêneros primários usados em outros contextos, destacando a importância de se mapear tais gêneros a fim de aumentar nossa compreensão sobre a natureza cultural do ensino.

Mapeamos apenas os gêneros discursivos presentes no planejamento da SD, mas consideramos em nossa análise a possibilidade de identificar como propõe Rockwell, os elementos de tantos outros gêneros, principalmente da modalidade oral, que circularam nas aulas, para além daqueles previamente planejados, como afirma a autora: "a performance do ensino não segue um script único; ao contrário, requer habilidade para integrar formas genéricas diversas e construir o ambiente discursivo para que funcionem na sala de aula" (ROCKWELL, 2012, p. 509).

Diante da constatação do gênero aula comportar multigêneros, reavaliamos o critério de análise, no qual inicialmente classificamos os gêneros textuais orais presentes no planejamento na SD como "produto", no sentido de reconhecer a participação ativa dos alunos no processo de elaboração dos mesmos. A partir do novo critério estabelecemos que o gênero oral só poderia ser classificado como "produto", se as formas estáveis do gênero tivessem sido trabalhadas sistematicamente com os alunos.

Na nova classificação apenas o gênero discursivo-textual oral Debate Regrado foi identificado como "produto", sendo o único que realizamos o registro audiovisual revelando assim nosso desconhecimento quanto a presença dos demais gêneros, sobretudo da modalidade oral presente nas aulas em que desenvolvemos as atividades da SD.

Nossa análise se voltou para entendermos como a oralidade enquanto gênero discursivo-textual colaborou e apoiou os alunos no processo de elaboração dos conceitos previstos ou não no planejamento da SD e dos discursos materializados em seus textos escritos, uma vez que, ao lermos as produções textuais dos alunos identificamos a presença de outros gêneros orais e que apenas a análise individualizada de um gênero oral gravado, $o$ Debate Regrado, seria insuficiente para demonstrarmos a presença e a importância da oralidade nas aulas de Geografia.

Nesta etapa estabelecemos os seguintes critérios análise: 
- Conceitos e traços da oralidade do gênero aula presentes nos textos dos alunos - apresentado no item 3.2.

- A experiência da aprendizagem mediada do Debate Regrado na aula de Geografia: o desafio de ensinar a oralidade na ação - apresentado no Capítulo 4.

$\mathrm{Na}$ busca de um elo entre os gêneros das modalidades oral e escrita e que apoiasse nossa opção de análise, encontramos nas pesquisas experimentais do Círculo de Vigotski $(1989)^{46}$ sobre o desenvolvimento dos signos pela criança, a afirmação de que os processos que compreendem os usos dos gestos e os simbolismos do brinquedo e do desenho, são acompanhados da linguagem falada até chegarem na escrita.

As contribuições de Vigotski (1995, p.197) para nossa compreensão do processo de aquisição e desenvolvimento do modo como a criança se utiliza das várias formas de representação, sobretudo na relação fala e escrita apontam que:

A compreensão da linguagem escrita ocorre por meio da linguagem oral, mas esta mudança é reduzida gradualmente; e o elo intermediário, que é a linguagem oral desaparece e a linguagem escrita passa a ter a característica simbólica, percebida da mesma forma que a linguagem oral. (tradução nossa $)^{47}$

A obra de Vigotski em espanhol utiliza-se das palavras "linguagem oral" e "linguagem escrita", porém adotamos para a "linguagem oral" a tradução "fala", em que Vigotski (1989, p. 131) nos aponta que há inicialmente um elo entre os modos de representação falado e escrito, apoiando assim a possibilidade de análise dos traços da oralidade ao longo das três dissertações escritas elaboradas pelos alunos ao longo da aplicação da SD e ao mesmo tempo distinguindo-as como duas formas complexas de linguagem e portanto, de ensino.

Há duas perspectivas que articulamos na análise do papel da oralidade enquanto gênero discursivo no Ensino de Geografia, considerando-as complementares e indispensáveis ao processo de aprendizagem dos alunos:

\footnotetext{
${ }^{46}$ Nos apoiamos nas pesquisas de Craig Brandist (2012, p.106) que em nota explica o emprego do conceito "Círculo de Vigotski" para se referir aos trabalhos de pesquisa, principalmente de Vigotski, Luria e A. N. Leontiev realizados em Moscou, Rússia e que se ligava ao Círculo de Bakhtin ao menos por um dos membros à Associação Russa de Institutos de Pesquisa Científica em Ciências Sociais.

${ }^{47}$ No original: "el lenguaje escrito se comprende a través del oral, pero ese cambio se va acortando poco a poco; el eslabón intermedio, que es el lenguaje oral, desaparece y el lenguaje escrito se hace directamente simbólico, percibido del mismo modo, que el lenguaje oral”. (VIGOTSKI, 1995, p.197)
} 
- Da fala como estruturante do pensamento, como afirma Vigotski (2010, p. 148): “as estruturas da linguagem dominada pela criança tornam-se estruturas básicas do seu pensamento".

- Da fala como prática social, como afirma Marcuschi (1998, p. 141): "Nos seus dois modos de uso - oralidade e escrita -, a língua é uma prática social que contribui para constituir; transmitir e preservar a própria memória dos feitos humanos".

As duas perspectivas, da fala como estruturante do pensamento e como prática social se articularam às pesquisas do Círculo de Vigotski, pelo campo da Psicologia da Aprendizagem, e do Círculo de Bakhtin, pelo campo da Filosofia da Linguagem seguindo a ideia da fala ${ }^{48}$, um objeto biológico numa perspectiva histórico-cultural, que pode colaborar com a estruturação do pensamento e da prática discursiva dos sujeitos.

Um dos pontos fundamentais da perspectiva da fala como estruturante do pensamento na criança é que inicialmente os dois processos, fala e pensamento, se desenvolvem distintamente e em um determinado momento se unem iniciando um novo desenvolvimento, o pensamento verbal, neste momento crucial "a fala se torna intelectual e o pensamento verbalizado" (VIGOTSKI, 2010, p.131).

O pensamento verbal oferece ao sujeito as condições de operar por meio de abstrações e generalizações em um processo constante de elaboração de conceitos em que as palavras possuem papel e importância fundamental.

Para Vigotski (2010, p. 243) existe o desenvolvimento de dois tipos de conceitos: conceitos espontâneos e conceitos científicos; com características próprias e caminhos distintos de elaboração:

Este caminho (de desenvolvimento dos conceitos científicos) se deve ao fato de que o momento da reviravolta no seu desenvolvimento é determinado pela definição verbal primária que, nas condições de um sistema organizado, descende ao concreto, ao fenômeno, ao passo que a tendência do desenvolvimento dos conceitos espontâneos se verifica fora do sistema, ascendendo para as generalizações.

A formulação de Vigotski quanto aos distintos processos de elaboração de conceitos espontâneos e científicos nos permitiu sair dos limites imediatos das atividades da SD para assumirmos que as experiências escolares podem assumir um caráter mais acadêmico, distanciando-se das experiências concretas do cotidiano próximo, como afirma Touraine

\footnotetext{
${ }^{48}$ Utilizamos a palavra "fala" seguindo as afirmações de Prestes (2010) quanto as traduções equivocadas do russo adotadas no Brasil como "linguagem" e que foram abordadas no decorrer do nosso texto nas p. 52-53.
} 
(2011, p.121) que considera que "sempre é possível dar ao indivíduo uma base mais sólida do que a experiência imediata dele mesmo".

Vigotski, em sua tese, afirma que é pelo mecanismo da fala, através da interação humana social, que o sujeito assimila todo o sistema cultural em que está inserido, aprendendo diferentes modos de pensar como afirma Marcuschi (1997, p.134):

A oralidade jamais desaparecerá e sempre será, ao lado da escrita, o grande meio de expressão e de atividade comunicativa. A oralidade enquanto prática social é inerente ao ser humano e não será substituída por nenhuma outra tecnologia. Ela sempre será a porta de nossa iniciação à racionalidade. A oralidade é também um fator de identidade social, regional, grupal dos indivíduos.

Marcuschi (2008, p.21) destaca a mudança de perspectiva dos estudos acerca da língua, que passa a ser o campo discursivo que se articulado às ideias de Vigotski e de Bakhtin colocam em relevo a aprendizagem de conhecimentos científicos, a partir da prática social, na escola, como esfera de ação, possibilitando aos sujeitos que teçam juntos, através de suas relações, os significados das palavras por meio de seus próprios enunciados como vínculos que ligam toda a experiência discursiva e suas estruturas de pensamento, conforme afirma

Bakhtin como Vigotski, Mead e os etnometodólogos, por caminho e visões muito diversos entre si, retiram a reflexão sobre a língua do campo da estrutura para situá-la no campo do discurso em seu contexto sociointerativo. (...) Neste caso, o enunciado se torna a unidade concreta e real da atividade comunicativa entre os indivíduos situados em contextos sociais sempre reais. (Grifo nosso)

O contexto sociointerativo apontado por Marcuschi como tendência em estudos de Linguística exige a noção do dialogismo, que em Bakhtin, tem como princípio que toda linguagem é dialógica, ou seja, todo enunciado é sempre um enunciado de alguém para alguém, daí a noção de gênero como enunciado responsivo "relativamente estável" reafirmando a ideia de linguagem como atividade interativa. (MARCUSCHI, 2008, p.20)

Sujeitos dialogam todo o tempo considerando outros enunciados, ou seja, os outros sujeitos discursivos, segundo Bakhtin (2010)

Observamos essa alternância dos sujeitos do discurso de modo mais simples e evidente no diálogo real, em que se alternam as enunciações dos interlocutores (parceiros do diálogo) aqui denominadas réplicas. Por sua precisão e simplicidade, o diálogo é a forma clássica de comunicação discursiva. (BAKHTIN, 2010, p.275)

Assim compreendido, o diálogo torna-se fundamental nas práticas docentes, e dessa forma não concebemos práticas que não considerem os discursos dos alunos e que não os 
conceba como sujeitos discursivos enunciadores "na corrente complexamente organizada de outros enunciados" (Bakhtin, 2010, p.272).

Bakhtin estabeleceu para as palavras a importância e o valor individual, no sentido de que os sujeitos que as empregam inserem seus desejos de acordo com a construção enunciativa e discursiva que pretendem comunicar. No processo comunicativo os sujeitos se apropriam de palavras que compõe os enunciados de outros sujeitos, estabelecendo assim, importantes elos de comunicação. Segundo Zandwais (2011, p.10)

Da mesma forma, podemos apontar também para o fato de que, no que tange ao ato de dizer, uma enunciação está sempre imersa em outras enunciações, como um processo reativo à palavra do outro que não pode ser apreendido como mera transmissão do dizer de outrem, dizer marcado, atestado na materialidade da língua, dizer contextualizado, linearizado, superficializado, identificável simplesmente por marcas estruturais, como faz a gramática ao opor as relações entre discursos citados e citantes, tratando-os como discursos direto e indireto. Ao contrário, as intersecções, os modos de articulação entre enunciações precisam ser tomados como relações ativas, ainda que nem sempre contextualizadas, por isso não transparentes, obrigando-nos, inelutavelmente, a interpretar. O dizer na "superfície" da língua trabalha porque conjuga em um mesmo enunciado múltiplas enunciações, vozes e "acentos" que estão dispersos em espaços e tempos distintos.

Nas práticas sociais, ou seja, "nos modos de articulação entre enunciações", como explica Zandwais (2011, p.10), em diferentes esferas de ação, sendo a escola uma delas, podem-se elaborar experiências de aprendizagem cada vez mais complexas para que os alunos possam assim avançar para além dos gêneros primários, típicos do cotidiano, para os gêneros secundários, típicos de situações de maior complexidade.

Articulando as duas perspectivas tanto da estruturação do pensamento, quanto dos modos de articulação entre enunciações adotamos os seguintes critérios de análise:

- A contribuição do gênero discursivo oral para a evolução do pensamento com leitura e escrita nas aulas de Geografia - apresentado no item 3.3.

- O necessário entrecruzamento da oralidade, da leitura e da escrita na SD por gênero discursivo oral - apresentado no item 4.1.do Capítulo 4.

- Novos conceitos e palavras chave do Debate Regrado na escrita - apresentado no item 4.2. do Capítulo 4.

- As capacidades de linguagem dos alunos e o Debate Regrado - apresentado no item 4.3. do Capítulo 4.

- Articulação de diferentes gêneros textuais pelos alunos no Debate Regrado e no texto escrito - apresentado no item 4.4. do Capítulo 4. 
Os critérios de análise nos permitiram por meio da fala dos alunos constituída de enunciados e organizada em gêneros discursivos compreender as relações entre oralidade e o processo de desenvolvimento de conceitos, questão tão cara ao Ensino de Geografia, para a formação de sujeitos, na sociedade.

\section{1. "O Brasil vai de quê?”: os caminhos da Sequência Didática pelos módulos de atividades}

Apresentamos anteriormente, no quadro 3, uma visão geral da Sequência Didática “O Brasil vai de quê", entretanto julgamos relevante explicar a natureza da escolha do contexto conceitual e didático que os alunos percorreram ao longo da aplicação da SD.

Ao longo dos anos de docência em Geografia, sem muito refletir acerca dos conteúdos, foi comum resumirmos os conteúdos do $7^{\circ}$ ano em uma só palavra: Brasil. Os objetivos, o registro do planejamento, bem como as atividades das aulas para o aprendizado dos alunos eram organizados a partir da temática territorial mais abrangente, o Brasil.

Ao analisarmos o livro didático de Geografia do $7^{\circ}$ ano da Coleção Radix, da editora Scipione, dos autores Beluce Bellucci e Valquíria Pires Garcia ${ }^{49}$, adotado nos anos letivos de 2012 a 2014 na escola em que aplicamos a Sequência Didática, podemos observar na maioria dos capítulos o enfoque dado ao espaço brasileiro:

- Módulo 1: Brasil: tanto lugares, tantas paisagens

- Módulo 2: O território brasileiro

- Módulo 3: A população brasileira

- Módulo 4: Rural e urbano: as duas faces do espaço geográfico brasileiro

- Módulo 5: As regiões brasileiras

- Módulo 6: O Centro-Sul

- Módulo 7: O Nordeste

- Módulo 8: A Amazônia

Buscamos também verificar se o foco dos estudos relacionados ao Brasil se repetia no documento de Orientações Curriculares e Proposição de Expectativas de Aprendizagem para o Ensino Fundamental: ciclo II: Geografia $(2007)^{50}$ da Rede de Ensino da Prefeitura de São Paulo elaborados pelas professoras Dr $^{\mathrm{a}}$ Sonia Maria Vanzella Castellar e Dr ${ }^{\mathrm{a}}$ Sueli Angelo Furlan ambas professoras da Universidade de São Paulo.

\footnotetext{
${ }^{49}$ PIRES, Valquíria \& BELLUCCI, Beluce. Projeto Radix: geografia, 7ºano. São Paulo: Scipione, 2009.

${ }^{50}$ São Paulo (SP). Secretaria Municipal de Educação. Diretoria de Orientação Técnica. Orientações curriculares e proposição de expectativas de aprendizagem para o Ensino Fundamental: ciclo II: Geografia / Secretaria Municipal de Educação - São Paulo: SME / DOT, 2007. 136p.
} 
Por meio da lista de Expectativas de Aprendizagem na p. 63 do documento foi possível identificar o enfoque ao espaço brasileiro coincidindo assim com a abordagem dada pelo livro didático de Geografia no $7^{\circ}$ Ano:

A partir do trabalho com os conteúdos geográficos, os conceitos, os eixos e os temas e as práticas metodológicas, espera-se que os estudantes possam:

- $\mathrm{G} 1^{51}$ Relacionar sociedade e natureza, reconhecendo suas interações na organização do espaço em diferentes contextos histórico-geográficos.

- G2 Reconhecer a formação socioespacial e a base para formação do povo brasileiro.

- G3 Utilizar a linguagem cartográfica para obter informações e representar a espacialidade dos fenômenos geográficos.

- G4 Identificar as características e a dinâmica dos fluxos populacionais.

- G5 Reconhecer aspectos do crescimento populacional.

- G6 Identificar relações entre urbanização e políticas públicas na cidade de São Paulo.

- G7 Compreender os fluxos populacionais e de capitais existentes entre os Estados brasileiros.

- G8 Identificar características urbanas em diferentes metrópoles e regiões metropolitanas e relacioná-las com o surgimento da indústria e a mobilidade social.

- G9 Compreender e interpretar os desafios políticos, econômicos e sociais criados durante o processo de formação da sociedade brasileira.

- G10 Conhecer as relações entre o homem e a natureza na construção do espaço geográfico brasileiro.

- G11 Relacionar a urbanização com a degradação versus conservação do ambiente.

- G12 Classificar fatos e dados sobre o consumo de energia.

- G13 Compreender o papel do aproveitamento dos recursos naturais renováveis e não-renováveis.

- G14 Relacionar a demanda dos recursos hídricos e áreas de mananciais com a urbanização e políticas públicas.

- G15 Identificar as bacias hidrográficas e sua função na economia e em relação aos impactos ambientais, a partir de interpretações cartográficas do espaço geográfico brasileiro.

- G16 Utilizar recursos da escrita, da observação, leitura e registro em procedimentos de pesquisa.

- G17 Analisar as formas de circulação de informação, capitais, mercadorias e serviços no tempo e no espaço.

- G18 Analisar dados de produção circulação e consumo; transporte e infraestrutura urbana em relação aos níveis de qualidade de vida das populações.

- G19 Reconhecer e interpretar as diferentes transformações que determinaram as várias formas de uso e apropriação dos espaços agrário e urbano industrial na história brasileira.

- G20 Reconhecer e analisar os vários movimentos sociais brasileiros e seu papel na transformação da realidade.

${ }^{51}$ A letra à frente do número de cada uma das expectativas de aprendizagem corresponde à disciplina do currículo escolar que se refere. 
- G21 Ler e interpretar tabelas e gráficos de estudos demográficos, e outros fatos socioambientais.

$\mathrm{Na}$ extensa lista de 21 Expectativas de Aprendizagem de Geografia para o $7^{\circ}$ ano apresentada pelo documento e que apoiavam os professores na elaboração do planejamento das aulas na Rede de Ensino do Município de São Paulo, é possível verificar 7 expectativas que recobrem explicitamente temas relacionados ao espaço brasileiro, como formação socioespacial, aspectos demográficos, fluxos populacionais, economia, urbanização, impactos ambientais etc., por meio da leitura e interpretação de mapas, gráficos, tabelas e pela realização de pesquisas. As demais expectativas de aprendizagem apresentadas pelo documento não apresentam explicitamente o espaço brasileiro para o ensino das temáticas apresentadas, mas ao que indica é possível realizá-las tendo como foco o Brasil.

Dando sequência, investigamos os Parâmetros Curriculares Nacionais de Geografia $(\mathrm{PCN})^{52}$ sobre o foco dos conteúdos ensinados no $7^{\circ}$ ano. Este documento ainda apresenta a organização do Ensino Fundamental II de oito anos ${ }^{53}$ e por isso os $6^{\circ}$ e $7^{\circ}$ anos estão agrupados no terceiro Ciclo e os $8^{\circ}$ e $9^{\circ}$ anos no quarto ciclo. Ao observarmos os conteúdos e eixos temáticos propostos para o terceiro ciclo, onde o $7^{\circ}$ ano está inserido, não há uma referência explícita aos estudos relacionados ao Brasil, o que é possível observar com a reprodução dos objetivos:

- Reconhecer que a sociedade e a natureza possuem princípios e leis próprios e que o espaço geográfico resulta das interações entre elas, historicamente definidas;

- Compreender a escala de importância no tempo e no espaço do local e do global e da multiplicidade de vivências com os lugares;

- Reconhecer a importância da cartografia como uma forma de linguagem para trabalhar em diferentes escalas espaciais as representações locais e globais do espaço geográfico;

- Distinguir as grandes unidades de paisagens em seus diferentes graus de humanização da natureza, inclusive a dinâmica de suas fronteiras, sejam elas naturais ou históricas, a exemplo das grandes paisagens naturais, as sociopolíticas como dos estados nacionais e cidade-campo;

- Compreender que os conhecimentos geográficos que adquiriram ao longo da escolaridade são parte da construção da sua cidadania, pois os homens constroem, se apropriam e interagem com o espaço geográfico nem sempre de forma igual;

\footnotetext{
52 BRASIL. Secretaria de Educação Fundamental. Parâmetros Curriculares Nacionais: Geografia / Secretaria de Educação Fundamental. Brasília: MEC/ SEF, 1998. 156 p.

${ }^{53} \mathrm{O}$ sistema educacional brasileiro está atualmente dividido em Educação Básica e Ensino Superior. De acordo com Lei de Diretrizes e Bases da Educação (LDB 9.394/96), a Educação Básica passou a ser estruturada por etapas e modalidades de ensino, englobando a Educação Infantil, o Ensino Fundamental obrigatório de nove anos e o Ensino Médio.
} 
- Perceber na paisagem local e no lugar em que vivem, as diferentes manifestações da natureza, sua apropriação e transformação pela ação da coletividade, de seu grupo social;

- Reconhecer e comparar a presença da natureza, expressa na paisagem local, com as manifestações da natureza presentes em outras paisagens;

- Reconhecer semelhanças e diferenças nos modos que diferentes grupos sociais se apropriam da natureza e a transformam, identificando suas determinações nas relações de trabalho, nos hábitos cotidianos, nas formas de se expressar e no lazer;

- Conhecer e utilizar fontes de informação escritas e imagéticas, utilizando, para tanto, alguns procedimentos básicos;

- Criar uma linguagem comunicativa, apropriando-se de elementos da linguagem gráfica utilizada nas representações cartográficas;

- Saber utilizar a observação e a descrição na leitura direta ou indireta da paisagem, sobretudo mediante ilustrações e linguagem oral;

- Reconhecer, no seu cotidiano, os referenciais espaciais de localização, orientação e distância, de modo que se desloque com autonomia e represente os lugares onde vivem e se relacionam;

- Reconhecer a importância de uma atitude responsável de cuidado com o meio em que vivem, evitando o desperdício e percebendo os cuidados que se devem ter na preservação e na conservação da natureza.

Por fim, identificamos por meio das temáticas dos volumes dos livros didáticos destinados ao $7^{\circ}$ ano indicados pelo Guia do Programa Nacional de Livros Didáticos de Geografia $^{54}$ temáticas de estudos relacionados explicitamente ao espaço brasileiro.

Ainda que os PCNs tratem os conteúdos de Geografia para o terceiro ciclo de uma maneira mais ampla quanto a escala de análise dos fenômenos, os livros didáticos, bem como o documento municipal de Expectativas de Aprendizagem apresentam a mesma tendência no tratamento do espaço brasileiro como objeto de ensino.

Encontramos uma relação entre o mercado editorial quanto à elaboração de documentos que apoiam e referenciam o trabalho de redes públicas de Ensino como no caso do município de São Paulo, além de determinar, em muitos casos, sem muitos questionamentos ou digressões o que os professores ensinam aos alunos.

Para desenvolver o nosso trabalho buscamos um contraponto entre os documentos de referência e os livros didáticos para uma temática geográfica inovadora ${ }^{55}$, de natureza ativamente responsiva e contextualizada e que pudesse ser articulada à perspectiva

\footnotetext{
${ }^{54}$ Guia de livros didáticos: PNLD 2014: Geografia: Ensino Fundamental: anos finais. - Brasília: Ministério da Educação, Secretaria de Educação Básica, 2013.144 p.

${ }^{55}$ Ao utilizarmos o termo "temática geográfica inovadora" nos referimos ao conceito de Ciência Viva no sentido de desenvolver nas aulas de Geografia questões acerca do espaço que ainda não temos as respostas, ou seja, questões-problemas em que os alunos possam discutir, investigar e encontrar suas respostas e/ou admitindo diferentes pontos de vista sobre o problema estudado. BALIBAR, Sébastien. A física numa escala humana. In: A religação dos saberes: o desafio do século XXI. Rio de Janeiro: Bertrand Brasil, 2007. p. 60-68.
} 
sociocultural de desenvolvimento e aprendizagem, além de privilegiar aspectos que corroborassem com nossa análise acerca da importância da oralidade para desenvolvimento de conceitos pelos alunos das turmas de $7^{\circ}$ anos.

Entre a diversidade temática da ciência geográfica escolhemos desenvolver com os alunos a discussão acerca da rede de transportes no Brasil, mobilizando assim um dos cinco procedimentos de pesquisa que Claval (2010, p.136) aponta para a Geografia caracterizando-a como uma disciplina complexa:

A Geografia analisa a mobilidade e a circulação, seja a dos homens, a dos bens ou aquelas das informações. Os circuitos se estruturam para responder às necessidades econômicas dos homens, para dividir as riquezas e bens simbólicos, bem como para assegurar a ordem.

Concordamos com George (1972, p.8) que diante da complexidade dos fenômenos espaciais, há a necessidade de metodologias heterogêneas de pesquisa, e consequentemente a especialização, entretanto sem renunciar a uma unidade de pensamento, que buscamos considerar durante o processo de pesquisa temática para elaboração da SD; encontramos assim uma das vertentes que tradicionalmente foi denominada "Geografia dos Transportes" em que:

destacam-se o estudo das redes, a relação entre o sistema de transportes e o desenvolvimento urbano e regional, a importância das políticas públicas ligadas ao setor, mobilidade e a acessibilidades, a sustentabilidade ambiental, as mudanças climáticas etc.” (SILVEIRA, 2011, p.10-11)

Silveira discute em seu artigo a proposta de uma nova nomenclatura para o termo tradicionalmente ainda utilizado "Geografia dos Transportes", como "Geografia da circulação, transporte e logística", dada as demandas contemporâneas e a complexidade das pesquisas na área.

Pierre Monbeig em 1956 já chamava a atenção das pesquisas que deveriam considerar a complexidade dos fenômenos geográficos, tal como vemos atualmente diante da questão dos problemas da rede de transportes no Brasil:

A pesquisa geográfica trata dos complexos de fatos e são esses complexos que, por sua localização no globo são verdadeiros "fatos" geográficos. Cabe ao geógrafo explicar esta localização, procurar-lhe as consequências, examinando as relações, ações e interações que unem uns aos outros os elementos constitutivos do complexo geográfico. Complexo geográfico, sim, porque se localiza e porque implica em ações recíprocas mutáveis do meio natural e do meio humano. A variedade dos componentes do complexo geográfico é tanto maior quanto mais elevado é o grau de civilização técnica atingida pelo grupo humano (...). (MONBEIG, 1956, p.9-10) 
Diante da complexidade de análise dos fenômenos geográficos Claval (2010, p.137) destaca que procedimentos de pesquisa que envolvem ecologia, tecnologia e organização social podem ser articulados em uma perspectiva normativa em que na sua visão:

A abordagem cultural dá liga aos conceitos que os homens têm da natureza, as atitudes que eles adotam quanto às técnicas e à mobilidade, os valores que os comportamentos sociais tencionam e as expectativas e os projetos que os homens imaginam para orientar suas vidas e lhes entreabrir o futuro.

Ainda que Claval (2010, p.136) estivesse apresentando procedimentos de pesquisa que direcionem a Geografia para a "compreensão do que faz o nosso planeta uma terra humana e dos perigos que a torna inabitável" e não especificamente para temáticas geográficas de ensino na Educação Básica, ainda sim, consideramos que pode ser uma das possibilidades de referencial para o ensino, pois acompanha a complexidade dos fenômenos geográficos como apontou Monbeig (1956) e do próprio pensamento complexo (MORIN, 2007, p. 14) para além dos sumários dos livros didáticos e dos documentos oficiais.

Consideramos que o desafio didático no planejamento de nossa SD foi integrar o conteúdo temático acerca da Rede de Transportes no Brasil às indicações mais abrangentes de pesquisa, sem desconsiderar a especialização na temática escolhida por meio de uma metodologia de ensino que incorporasse as demandas sociais e cognitivas dos adolescentes.

A proposta de elaboração textual pelos alunos de acordo com o modelo de SD adotado ocorre a partir de um desafio comunicacional, entretanto, para a aula de Geografia, o desafio inicial foi uma questão problema relacionada ao espaço e que apoiasse a elaboração de conceitos, pois segundo Vigotski (2010, p. 237): "a formação de conceitos surge sempre no processo de solução de algum problema que se coloca para o pensamento do adolescente".

Mesmo sem o enfoque de um problema comunicacional, como no caso daqueles desenvolvidos nas aulas de Língua Portuguesa de acordo com o modelo de SD de Schneuwly, Dolz e seus colaboradores, a questão problema apresentada aos alunos envolveu ao longo dos estudos a elaboração de três dissertações da esfera escolar/acadêmica, do gênero discursivotextual dissertação, sendo uma inicial, uma intermediária e uma dissertação final, todas na modalidade escrita; além do Debate Regrado, na modalidade oral.

O modelo de planejamento adotado por nós ${ }^{56}$ constitui o modelo elaborado no processo da terceira etapa de aplicação de SD pelos participantes do Círculo de Estudos e Pesquisas para a Formação de Professores de Geografia no ano de 2013 e que contempla a

\footnotetext{
56 Os alunos receberam uma cópia idêntica do planejamento de cada um dos módulos da SD e assim acompanhavam todo o desenvolvimento dos trabalhos com o objetivo de mediarmos o critério da intencionalidade e reciprocidade, segundo Feuerstein (2014, p.83).
} 
articulação metodológica das fronteiras teóricas que por interfaces e aproximações delinearam todo o trabalho de pesquisa em que estamos inseridos como já explicitado anteriormente.

Logo no início das atividades dos módulos organizamos os alunos em grupos que receberam os nomes dos sistemas de transportes que seriam estudados ao longo da SD, esta organização tinha como objetivo aproximar os alunos, sobretudo, das novas palavras que circulariam nas aulas a partir da apresentação da questão-problema.

Figura 4 - Fotografia da folha de registro da organização dos grupos de trabalho do $7^{\circ}$ Ano B

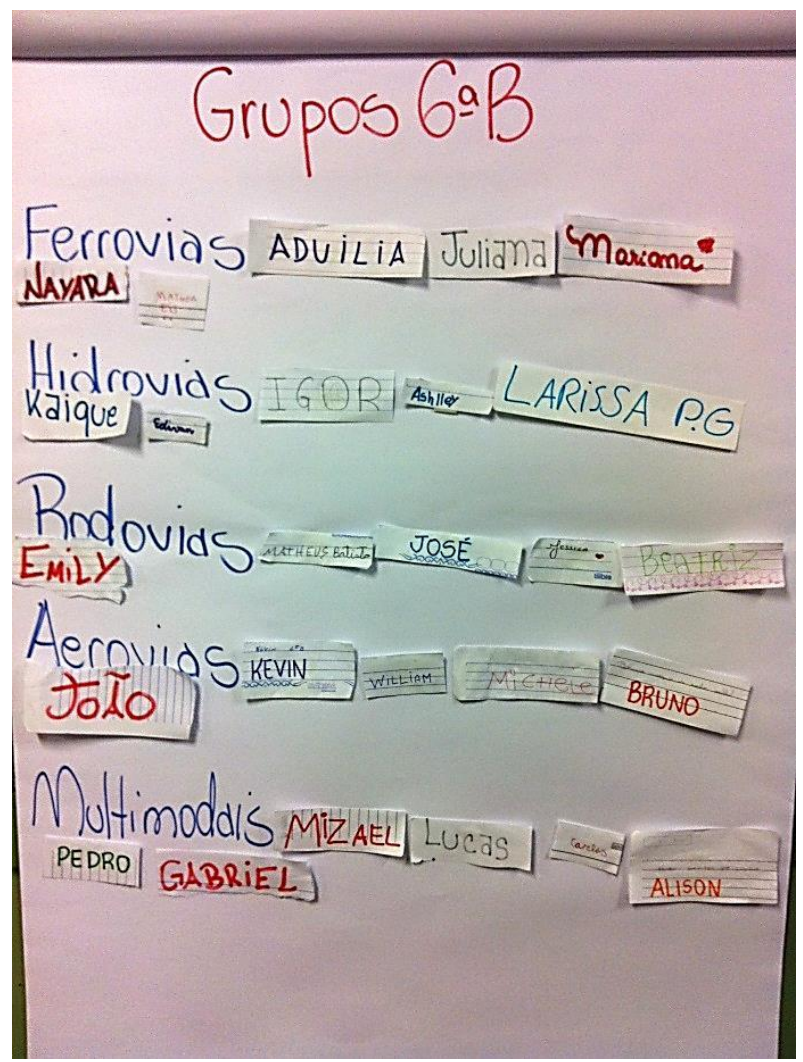

Fonte: Ketlin E. T. W. Fiocco, agosto, 2013.

As atividades que envolveram a discussão, elaboração e avaliação do gênero discursivo-textual na modalidade escrita foram organizadas no módulo denominado "Leitor Crítico" que foi sendo alternado entre os demais módulos. Neste módulo além da elaboração escrita, também havia um instrumento de mediação ${ }^{57}$ denominado "Grade de correção para a avaliação das dissertações" que deveria ser preenchido pelo professor e por outro aluno por

\footnotetext{
${ }^{57}$ Uma das fronteiras teóricas adotadas por nós é a Teoria da Experiência de Aprendizagem Mediada de Reuven Feuerstein que utiliza o conceito de "instrumentos de mediação" para o conjunto de "situações que constam das fichas de trabalho, cuja finalidade primordial é compensar as disfunções cognitivas e redesenvolver e restaurar as funções de input, elaboração, e output do ato mental". (FONSECA, 1998, p.114)
} 
meio de critérios estabelecidos a partir das competências do Exame Nacional do Ensino Médio (ENEM) ${ }^{58}$.

Realizamos a discussão a partir de um roteiro de questões acerca do gênero textual e discursivo que permeou toda a sequência didática. A opção foi pelo discurso da esfera acadêmica sendo este considerado um gênero discursivo importante e estruturante para outros que os alunos terão contato em suas vidas, nas diferentes situações comunicacionais escolares ou não. Seguimos esta opção em nossa prática e propusemos aos alunos a elaboração de dissertações com o objetivo de desenvolver a capacidade de linguagem argumentativa.

A concepção do trabalho didático com módulos de ensino no contexto de uma SD por gênero discursivo-textual, de acordo com Schneuwly e Dolz (2010, p. 87-88) ocorre por meio do seguinte movimento:

Nos módulos, trata-se de trabalhar os problemas que apareceram na primeira produção e de dar aos alunos os instrumentos necessários para superá-los. A atividade de produzir um texto escrito ou oral é, de uma certa maneira, decomposta, para abordar, um a um, separadamente, seus diversos elementos (...). O movimento geral da sequência didática vai, portanto, do complexo para o simples: da produção inicial aos módulos, cada um trabalhando uma ou outra capacidade necessária ao domínio de um gênero.

Os autores Schneuwly e Dolz (2010, p. 87-88) compreendem o trabalho didático como o domínio de determinado gênero discursivo-textual, mas que quanto a este aspecto há uma diferenciação quando a proposta se aplica a outra disciplina do currículo escolar, pois além dos elementos estáveis do gênero escolhido para a SD há outros aspectos que percorrem o ensino científico.

Entre outros aspectos do ensino científico na Educação Básica, Alexandre e Agraso (2006, p. 17) destacam que: “O conhecimento científico é diferente do de outros domínios (...) porque os enunciados, conclusões, hipóteses ou teorias não constituem meras opiniões, mas devem estar sustentadas em provas, dados empíricos ou respaldado de natureza teórica".

Nossa preocupação foi articular, além do domínio do gênero, o processo de elaboração de conceitos científicos pelos alunos relacionados à temática proposta na SD e para isso optamos por investigar em cada um dos textos escritos se os alunos abordaram ou não a questão problema, sendo esta uma das etapas de desenvolvimento dos conceitos, ou seja o desafio de pensar acerca de um tema e/ou problema que nunca tinham pensado antes. Para

\footnotetext{
${ }^{58}$ De uma maneira geral as competências e habilidades referem-se ao domínio de linguagens, compreensão de fenômenos, enfrentamento e resolução de situações-problema, capacidade de argumentação e elaboração de propostas, de acordo com os documentos disponíveis em: http://portal.inep.gov.br/web/encceja/matriz-decompetencia, acesso em 06 mai. 2016.
} 
isso elaboramos o quadro 7 a fim de analisar os domínios apresentados pelos alunos no texto escrito, articulando aspectos relacionados aos conceitos científicos.

A Análise I, indica o domínio do tema, assunto e conteúdo. A Análise II apresenta os aspectos do domínio dos elementos estáveis do gênero.

Quadro 7 - Análise dos Domínios apresentados pelos alunos nas elaborações escritas.

\begin{tabular}{|c|c|c|c|c|c|}
\hline \multirow{3}{*}{$\begin{array}{l}\text { Elaborações } \\
\text { textuais }\end{array}$} & \multirow{2}{*}{\multicolumn{2}{|c|}{$\begin{array}{c}\text { Análise I } \\
\text { Domínio do } \\
\text { Tema/Assunto/Conteúdo }\end{array}$}} & \multirow{2}{*}{\multicolumn{2}{|c|}{$\begin{array}{c}\text { Análise II } \\
\begin{array}{c}\text { Domínio do Gênero } \\
\text { Textual }\end{array}\end{array}$}} & \multirow{3}{*}{$\begin{array}{c}\text { Comparativo entre } \\
\text { os dados } \\
\\
\text { Número de alunos } \\
\text { que abordaram a } \\
\text { questão problema da } \\
\text { SD e atenderam ao } \\
\text { gênero proposto }\end{array}$} \\
\hline & & & & & \\
\hline & $\begin{array}{l}\text { Abordaram } \\
\text { o problema }\end{array}$ & $\begin{array}{c}\text { Não } \\
\text { abordaram o } \\
\text { problema }\end{array}$ & $\begin{array}{l}\text { Atenderam } \\
\text { ao Gênero }\end{array}$ & $\begin{array}{c}\text { Não } \\
\text { atenderam } \\
\text { ao Gênero }\end{array}$ & \\
\hline Inicial & 47 & 6 & 37 & 16 & 35 \\
\hline Intermediária & 49 & 4 & 35 & 18 & 33 \\
\hline Final & 51 & 2 & 46 & 7 & 46 \\
\hline
\end{tabular}

Fonte: Elaboração Ketlin E. T. W. Fiocco.

É possível observar que ao longo da aplicação da SD há o aumento do número de 35 para 46 alunos que passaram a abordar a questão problema da SD ao produzir a dissertação e a atender ao gênero proposto exigindo reflexão dos enunciados dos alunos, para uma compreensão profunda das temáticas abordadas e a aproximação delas com o problema proposto sobre a Rede de Transportes no Brasil, bem como para a escolha dos instrumentos capazes de mobilizar as Funções Cognitivas que apoiassem a organização dos enunciados e argumentos por meio de textos mais bem estruturados.

Para a articulação dos dois domínios, domínio conceitual e domínio do gênero, nos pareceu imprescindível também apoiar os alunos na elaboração de argumentos, segundo os trabalhos de pesquisa de Driver, Newton e Osborne (2000) buscamos compreender a coerência do caminho metodológico que escolhemos como proposta ao Ensino de Geografia, relacionando os conceitos científicos por meio do tema, assunto e conteúdo da SD, ao domínio relacionado ao gênero textual.

Driver, Newton e Osborne (2000, p.288) ao criticarem a Ciência ensinada a partir de uma perspectiva positivista com respostas certas e onde os dados levam sem discussões a conclusões acordadas, convergiram para a concepção de nossa pesquisa voltada para o ensino de uma Ciência Viva. 
A perspectiva positivista no sentido da reprodução de respostas prontas se rompe com a possibilidade de novos conhecimentos quando propomos um trabalho em que os alunos são colocados diante do desafio de pensar, escrever e falar sobre uma temática científica, como afirmam os autores:

Nós gostaríamos de afirmar que, se a educação científica é para ajudar os jovens a se envolverem com as afirmações produzidas através de um "fazer científico", a educação científica deve dar oportunidade para estas formas de argumento através da promoção de atividades de sala de aula apropriadas e associadas a práticas discursivas. Tais práticas e apenas tais práticas são o significado da socialização dos jovens dentro das normas dos argumentos científicos de que podem ganhar confiança no seu uso, e uma compreensão profunda do seu funcionamento e valor. (DRIVER, NEWTON e OSBORNE, 2000, p.288, tradução nossa) ${ }^{59}$

O modelo de planejamento de Sequência Didática por gênero discursivo nos possibilitou propor atividades com foco na argumentação científica articulando-a a elaboração de textos escritos e orais, que correspondem às práticas discursivas.

No módulo um da SD denominado posteriormente de "Articuladores sintáticos e tipos de argumentos" as atividades se relacionam ao que encontramos na dissertação de Márcio Masatoshi Kondo: "Transporte multimodal é a melhor opção para o Brasil"60 em que o autor se posiciona acerca da solução para os problemas da rede de transportes no Brasil.

Os articuladores sintáticos e os tipos de argumentos foram organizados em tabelas de modo que pudessem apoiar os alunos nas atividades de identificação de tais articuladores e argumentos no texto de Kondo (2005) e durante a elaboração de suas próprias dissertações enfatizando assim a importância da argumentação ao se posicionarem diante de alguma situação que imponha tal postura.

Neste módulo os alunos organizaram pequenos cartazes com o registro dos argumentos contrários e favoráveis ao sistema de transporte que cada um dos grupos representava, ficando expostos na sala ambiente de Geografia para utilização como referência durante as aulas e para as elaborações textuais ao longo da aplicação da SD.

Logo depois das atividades do módulo 1 os alunos escreveram a dissertação intermediária e retomaram as propostas do módulo 2 da SD denominado "Leitor Crítico".

\footnotetext{
${ }^{59}$ We would contend that, if science education is to help young people engage with the claims produced by science-in-the-making, science education must give access to these forms of argument through promoting appropriate classroom activities and their associated discursive practices. Such practices, and only such practices, are the means of socializing young people into the norms of scientific argument from which they may gain confidence in their use, and a deeper understanding of their function and value. (DRIVER, NEWTON e OSBORNE, 2000, p.288)

${ }^{60}$ Disponível em: http://vestibular.uol.com.br/resumo-das-disciplinas/geopolitica/transporte-multimodal-e-amelhor-opcao-para-o-brasil.htm Acesso em 04 set. 2016.
} 
Figura 5 - Fotografia dos registros elaborados pelos alunos e fixados na sala ambiente de Geografia.

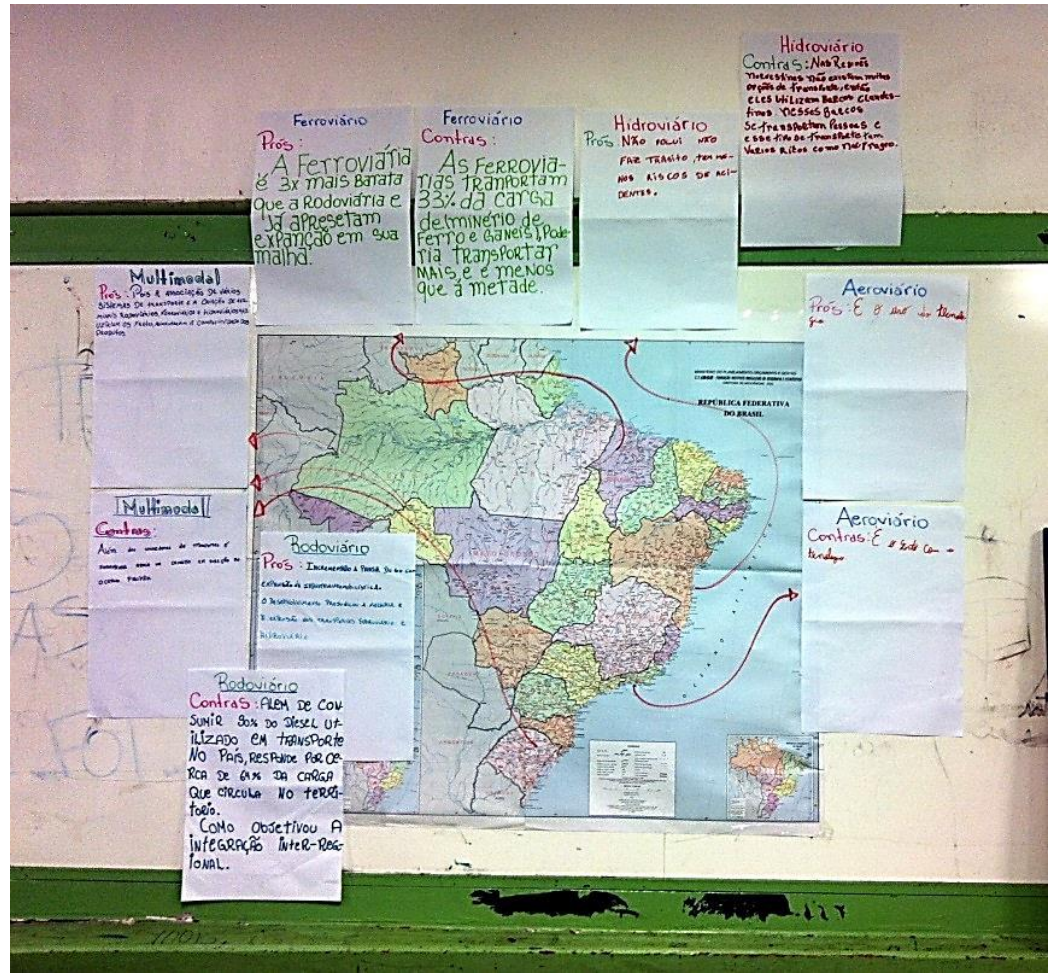

Fonte: Ketlin E. T. W. Fiocco, Setembro, 2013.

O trabalho no módulo três "Cartografia" teve como foco a representação cartográfica do fenômeno estudado, e assim, apresentamos um mapa da rede multimodal de transportes Brasil (2002) aos alunos, que elaboraram coletivamente uma tabela e um comentário com a descrição da distribuição dos transportes terrestres no Brasil, a fim de compreender a distribuição, a localização pelo território e o levantamento de hipóteses que possam explicar o fenômeno identificado.

No módulo quatro, denominado "Análise do setor de transportes no Brasil e Debate Regrado" planejamos apresentar aos alunos um texto mais longo com o mesmo título do módulo em que novamente retomariam a identificação dos articuladores sintáticos, bem como os tipos de argumento no texto, mas este não foi realizado a contento por todas as turmas, sendo que a gestão do tempo que articula número de aulas e ritmos de aprendizagem dos alunos, incidiu como variável decisiva nesta atividade.

A análise atenta e criteriosa das dissertações elaboradas pelos alunos e da participação deles em cada uma das atividades possibilitou o que afirmamos anteriormente sobre a necessidade de mudança, ou o replanejamento contínuo, a fim de realizar os ajustes necessários, para que as atividades dos módulos propiciassem aos alunos, oportunidades para que avançassem em suas formas de pensamento, visando a análise da complexidade dos fenômenos, por meio do desenvolvimento de conceitos científicos. 
Destacamos duas mudanças que julgamos importante considerar durante o processo de aplicação da SD. A primeira foi a proposta de uma pesquisa por meio de um roteiro sobre as redes de transportes de outros países, com o objetivo de oferecer aos alunos novos repertórios para que apoiassem a elaboração de argumentos por exemplos na última dissertação que realizaram.

A segunda mudança no planejamento esteve relacionada com a leitura pelos alunos do texto "Análise do setor de transportes" de Sabrina Erhart e Eduardo Mauch Palmeira (2006) que devido à extensão do texto escolhido aliado ao tempo disponível para a atividade de leitura do texto proposto, optamos por focalizar o trabalho didático por meio das palavraschave apoiados no complexo processo de elaboração dos conceitos científicos como afirma Vigotski (2010, p. 251):

O ensino consciente de novos conceitos e formas da palavra ao aluno não só é possível como pode ser fonte de um desenvolvimento superior dos conceitos propriamente ditos e já constituídos na criança, que é possível o trabalho direto com o conceito no processo de ensino escolar. Mas, (...), este trabalho não é o fim, mas o início do desenvolvimento do conceito científico, e não só não exclui os processos propriamente ditos de desenvolvimento como lhes dá uma nova orientação e coloca os processos de aprendizagem e desenvolvimento em novas relações maximamente favoráveis do ponto de vista dos objetivos finais da escola.

A opção do trabalho didático com as palavras-chave caracterizou a segunda mudança que realizamos no módulo 4, antes da elaboração da última dissertação pelos alunos, momento em que as informações do texto foram organizadas coletivamente com a turma, em listas com palavras-chave digitadas, ampliadas, impressas e entregues aos alunos aleatoriamente. Organizamos a leitura das palavras pelos alunos que deveriam empregá-las na lista correspondente de acordo com a seguinte estrutura:

- Lista 1: Identificação dos problemas da Rede de Transportes no Brasil (RT)

- Lista 2: Consequências dos problemas da RT com foco nas exportações

- Lista 3: Possíveis soluções para os problemas da RT

- Lista 4: Possíveis consequências das soluções aos problemas da RT

As listas ficaram expostas na sala ambiente de Geografia e apoiaram efetivamente os alunos no processo de elaboração da dissertação final, bem como a inserção de um roteiro elaborado posteriormente como novo instrumento de mediação.

O Debate Regrado, enquanto gênero discursivo-textual oral e previsto no módulo 4 foi desenvolvido em turnos com os alunos de cada uma das turmas e como apoio julgamos 
importante elaborar mais um instrumento que colaborasse com o desenvolvimento do Debate sendo que a análise será apresentada em capítulo posterior de nossa dissertação.

Nosso trabalho de aplicação de SD se estendeu além do tempo planejado e por isso o módulo cinco "Leitor crítico" em que tinham que avaliar a partir de critérios a própria dissertação e a dissertação de um colega, não foi realizado pelos alunos que, apesar do calendário escolar prever aulas no mês de dezembro, deixaram de comparecer à escola.

Quanto ao tempo de duração de aplicação de uma Sequência Didática extrapolamos o que Dolz (2015) indica como o tempo ideal para "a memória didática do aluno" que seria de no máximo 3 semanas. Considerando que a carga horária de Língua Portuguesa, em geral são 5 aulas semanais somando assim 15 aulas para o desenvolvimento de uma SD; para a Geografia, que em média possui 3 aulas semanais, uma SD duraria 5 semanas.

Dada a complexa mudança proposta para a prática docente implicada na abordagem do plano da SD “O Brasil vai de quê?”, a previsão inicial era de 30 aulas somando 10 semanas, ou seja, o dobro de semanas propostas por Dolz (2015); ainda assim utilizamos efetivamente 49 aulas em média para as três turmas, sendo este um dos aspectos de revisão do nosso trabalho didático, pois durante a aplicação tivemos o desafio de mediar constantemente a memória do processo desenvolvidos com os alunos. Consideramos que a relação entre os aspectos da complexidade da temática geográfica de ensino, o aspecto da progressão dos conhecimentos ao longo da escolaridade e o tempo da escola podem ser objeto de estudos posteriores.

Apresentamos neste capítulo o diálogo inicial entre o modelo de Sequência Didática por gênero discursivo-textual e o Ensino de Geografia numa perspectiva sociocultural em que a formação discursiva do sujeito tem papel central nas opções didáticas e metodológicas no contexto das aulas de Geografia.

\subsection{Conceitos e traços da oralidade no texto escrito dos alunos}


Figura 6 - Fotografia do Flipchart exposto na entrada da sala ambiente de Geografia.

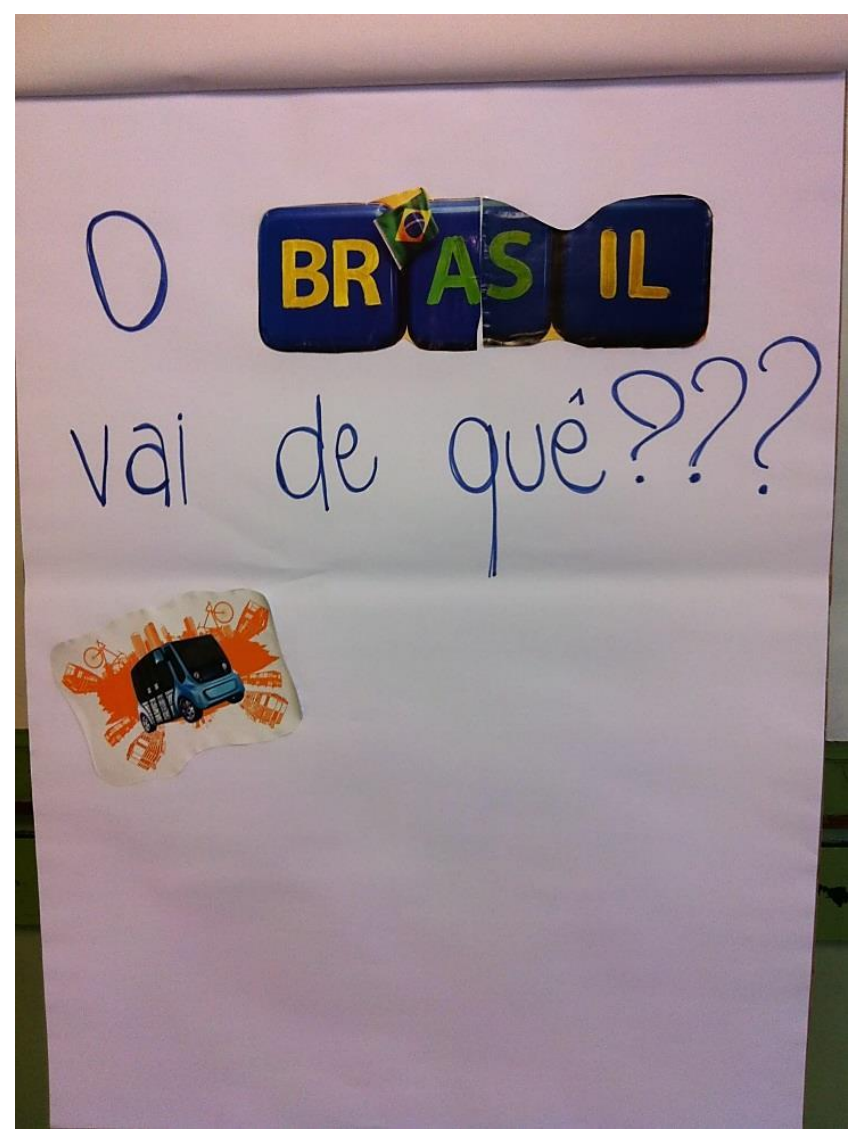

Fonte: Ketlin E. T. W. Fiocco, agosto, 2013

A Sequência Didática “O Brasil vai de quê?” teve como foco o desenvolvimento da capacidade argumentativa dos alunos frente a um problema em que tinham que se posicionar e defender o seu ponto de vista. O problema apresentado e desenvolvido nas aulas de Geografia estava relacionado com a busca de possíveis soluções para os problemas da Rede de Transportes no Brasil.

Providenciamos um cavalete com um bloco de folhas posicionado na entrada da sala tendo, na primeira folha, o título da Sequência Didática e uma ilustração contendo um ônibus no centro e outros meios de transportes, como bicicletas, vagões de trens e outros ônibus saindo ao fundo, recortado de uma revista.

Posteriormente e, ao longo das atividades desenvolvidas durante a aplicação da SD, essa folha que nos serviu de capa dos registros das aulas ganhou novas palavras e ilustrações, entretanto, na primeira atividade, nossa mediação partiu apenas da pergunta "O Brasil vai de quê?" nos apoiando na inauguração dos trabalhos da Sequência Didática com as turmas.

Como afirma Marcuschi (1998) “o ser humano é um ser que fala e não um ser que escreve" e a aula por sua vez, espaço vibrante da fala de crianças e jovens num processo 
constante de comunicação primordial para a prática social como podemos observar no início da aplicação da SD.

A pergunta "O Brasil vai de quê?", título da SD, direcionada aos alunos de todas as turmas envolvidas, desencadeou a participação oral e espontânea dos alunos por meio de uma lista de palavras com exemplos de meios de transportes que posteriormente pudemos observar em seus textos escritos.

Ainda que o conceito principal envolvido no problema da SD dizia respeito à Rede de Transportes no Brasil, o conceito de meios de transporte foi amplamente utilizado nas primeiras elaborações textuais nos indicando dois aspectos, o primeiro que os alunos, de alguma maneira, já utilizavam o conceito de meios de transportes, sendo este relacionado mais diretamente com o imediato do cotidiano, além do trabalho do conceito ao longo da própria escolarização; o segundo aspecto é que incialmente, ao acolher as respostas dos alunos sobre os meios de transportes, afirmamos para eles de certo modo que o conceito já consolidado por eles poderia ser utilizado como apoio para a resposta inicial da SD em seus textos escritos.

Ao lermos as elaborações textuais dos alunos agrupamos os conceitos em: "MEIOS DE TRANSPORTES"; “TRANSPORTE PÚBLICO” e "REDE DE TRANSPORTE" apresentados no quadro 8 , e que foram utilizados na resposta à questão problema: “A exemplo de muitos países europeus com vasta malha ferroviária é comum ouvir que a solução para os problemas da rede de transportes no Brasil são investimentos neste modal. Seria esta a solução para os problemas de transporte no Brasil?”.

Quadro 8 - Conceitos utilizados pelos alunos nas produções escritas e as respectivas siglas.

\begin{tabular}{|l|c|}
\hline \multicolumn{1}{|c|}{ CONCEITOS } & $\begin{array}{c}\text { SIGLAS } \\
\text { ADOTADAS }\end{array}$ \\
\hline MEIOS DE TRANSPORTES & MT \\
\hline TRANSPORTE PÚBLICO & TP \\
\hline REDE DE TRANSPORTES & RD \\
\hline
\end{tabular}

Fonte: Elaboração Ketlin E. T. W. Fiocco.

Organizamos os dados referentes aos conceitos somando, em cada uma das elaborações, o número total de vezes que os alunos utilizaram esses conceitos em seus textos para responderem ao problema da $\mathrm{SD}$, sendo que para a $1^{\mathrm{a}}$ elaboração foram 75 referências aos conceitos, na $2^{\text {a }}$ elaboração 102 e na $3^{\text {a }}$ elaboração 71 referências. Temos então as seguintes proporções: 
Gráfico 6 - Conceitos utilizados pelos alunos da amostra válida na elaboração textual inicial.

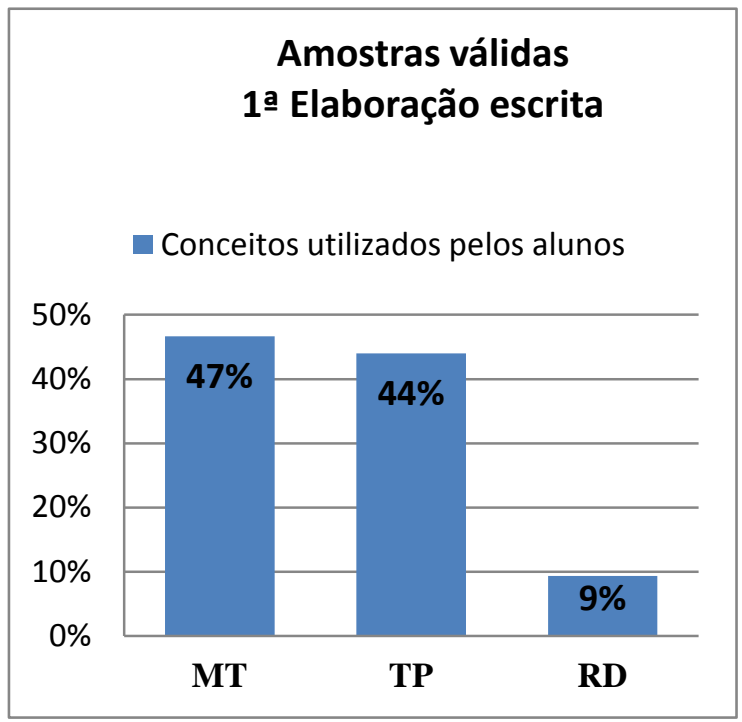

Fonte: Elaboração Ketlin E. T. W. Fiocco.
Gráfico 5 - Conceitos utilizados pelos alunos da amostra válida na elaboração textual intermediária.

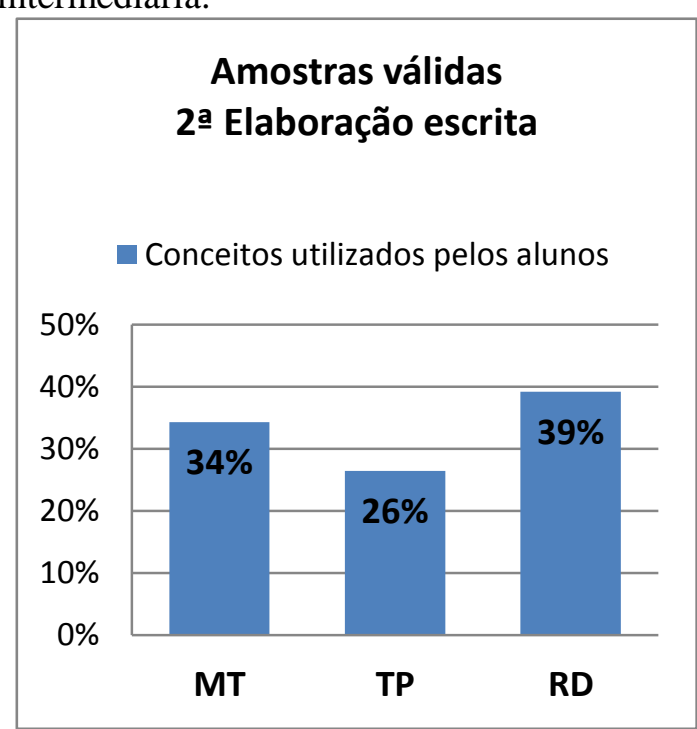

Fonte: Elaboração Ketlin E. T. W. Fiocco.

Gráfico 7 - Conceitos utilizados pelos alunos da amostra válida na elaboração textual final.

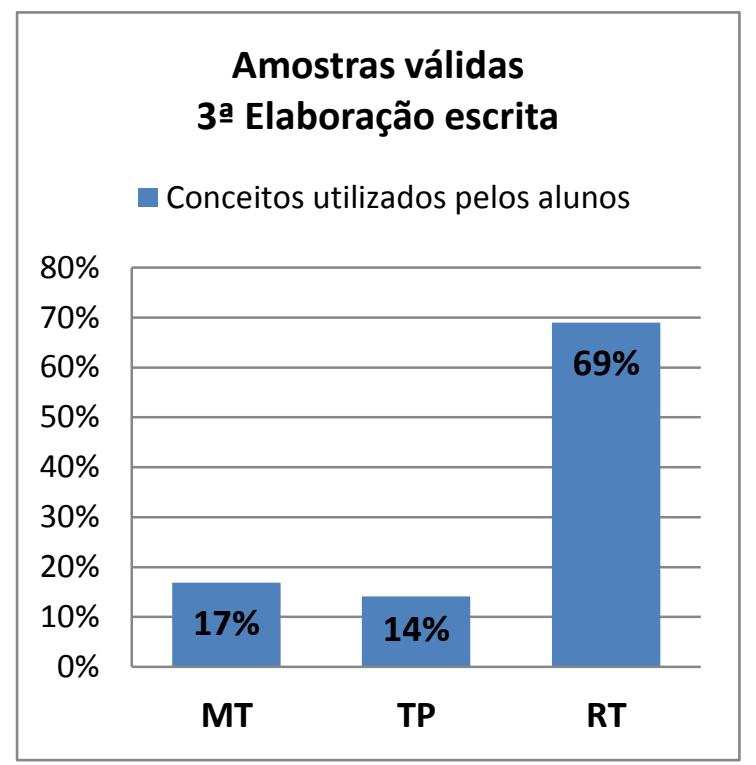

Fonte: Elaboração Ketlin E. T. W. Fiocco.

Entre os conceitos utilizados pelos alunos podemos observar que, inicialmente, os mais utilizados para responderem ao problema da Sequência Didática foram "MEIOS DE TRANSPORTE", com 47\% das referências dos textos da $1^{\text {a }}$ elaboração, "TRANSPORTE PÚBLICO”, com 44\% e "REDE DE TRANSPORTE” com apenas 9\%.

Progressivamente os conceitos "MEIOS DE TRANSPORTE" e "TRANSPORTE PÚBLICO" deixam de apoiar as respostas dos alunos e o conceito "REDE DE TRANSPORTE" passa a fazer parte das referências dos alunos para explicarem seus pontos de vista acerca do problema apresentado com $69 \%$ das referências. 
Estes dados nos apontam, entre outros aspectos, o impacto e a relação direta da oralidade no processo de elaboração do pensamento dos alunos e consequentemente representados na elaboração escrita dos mesmos, como podemos verificar nos exemplos selecionados:

Quadro 9 - Trecho de elaboração textual com exemplo de conceito utilizado por aluno da turma A.

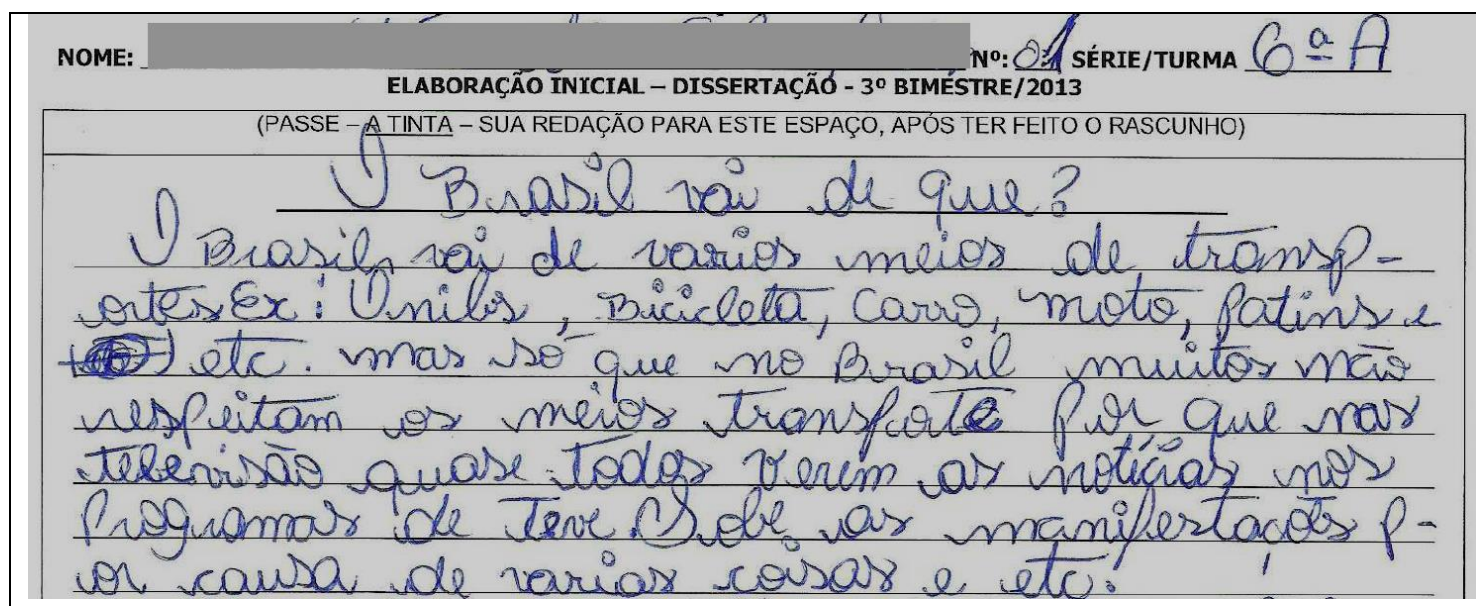

Versão original: O Brasil vai de que?

O Brasil vai de varios meios de transportes.Ex: Onibus, Bicicleta, Carro, Moto, Patins e

etc.Mas só que no Brasil muitos não respeitam os meios transporte por que nas televisão quase todos verem as notícias nos programas de teve.Sobe as manifestações por causa de varias coisas e etc.

Fonte: Acervo de pesquisa da SD "O Brasil vai de quê?"

Quadro 10 - Trecho de elaboração textual com exemplo de conceito utilizado por aluno da turma B.

\begin{tabular}{|c|c|}
\hline \multirow{2}{*}{\multicolumn{2}{|c|}{ ELABORAÇÃO INICIAL - DISSERTAÇÃO - $3^{\circ}$ BIMESTRE/2013 }} \\
\hline & \\
\hline & (PASSE - A TINTA - SUA REDAÇÁO PARA ESTE ESPAÇO, APÓS TER FEITO O RASCUNHO) \\
\hline & OBrasie vai de quen \\
\hline & 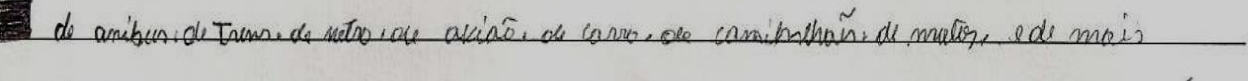 \\
\hline Thans & 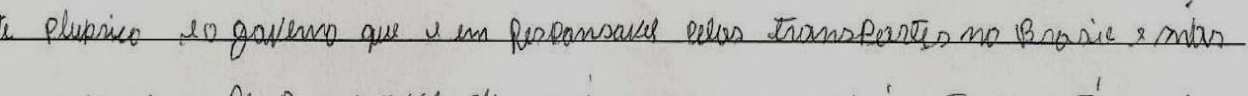 \\
\hline Ress & - as en perpansowal de man mesmo e vain te que Isra do \\
\hline 40550 & Inalache e da vo BOUSO Pass as inanspartes ma Brasie? \\
\hline
\end{tabular}

Versão original: $O$ Brasil vai de quer

de onibus, de trens, de metro e de avião e de carro e de caminhões e de matos e de mais 
Transporte publico e o governo que e im responsavel pelos transportes no Brasil e de mias

Pessoas e as em responsavel de mais mesmo e nais te que tira do

nosso trabalho e do no bouso para as transporte no Brasil?

Fonte: Acervo de pesquisa da SD "O Brasil vai de quê?"

Quadro 11 - Trecho de elaboração textual com exemplo de conceito utilizado por aluno da turma C.

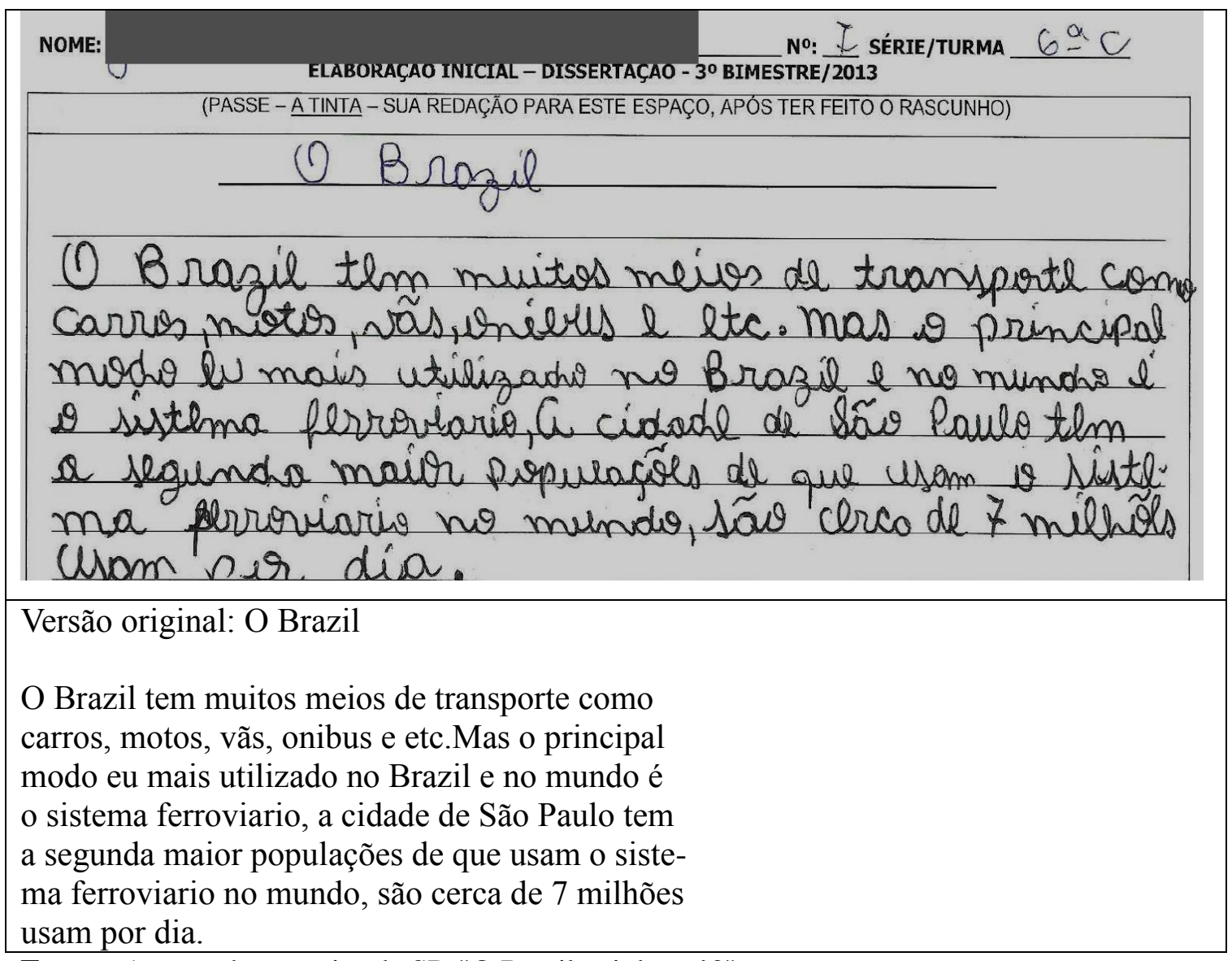

Fonte: Acervo de pesquisa da SD "O Brasil vai de quê?"

Podemos observar que os dois alunos das turmas A e B reproduzem em seus textos quase que literalmente a exposição oral dos colegas durante a aula inicial, indicando que ainda não possuíam o domínio das diferentes estruturas estáveis dos gêneros textuais nas modalidades escrita e oral. Mesmo a elaboração textual ocorrendo quase um mês depois da aula inicial o texto escrito apresenta todos os elementos da oralidade que foram apresentados e desenvolvidos no momento inicial da aplicação da SD.

$\mathrm{O}$ terceiro aluno, da turma $\mathrm{C}$, se distancia de aspectos próprios da oralidade, entretanto desenvolve a ideia do seu texto a partir do conceito de meios de transporte que esteve presente durante a aula inicial.

Os exemplos escolhidos nos indicam aspectos acerca do processo de elaboração de conceitos em que Vigotski (2010, p.220) nos apresenta uma longa explicação, por meio do 
uso das palavras por crianças e adolescentes, ressaltando que o modo como se utilizam delas não significa que já operam por conceitos, pois este tipo de pensamento possui características próprias que “(...) pressupõe a discriminação, a abstração e o isolamento de determinados elementos e ainda a habilidade de examinar esses elementos discriminados e abstraídos fora do vínculo concreto e factual em que são dados na experiência.” (Grifo nosso).

Por isso afirmamos que o simples exame das palavras que circularam nas aulas iniciais de apresentação do problema da SD e que constatadas sua utilização pelos alunos nos textos escritos apenas nos aludem a indícios de partes do processo complexo de elaboração de conceitos, entretanto a análise atenta pode trazer à tona uma ação prospectiva de pensar o Ensino de Geografia a fim de favorecer cada vez mais o processo de elaboração de pensamentos por conceitos pelos alunos.

Julgamos relevante descrevermos, de acordo com Vigotski (2010, p. 150-239), ainda que de maneira sintética, o seu estudo experimental do desenvolvimento de conceitos que foi denominado como método sintético-genérico em que explica como a criança opera com a palavra no processo vivo de solução de um problema.

O processo vivo de solução de um problema nos remete à articulação do processo de elaboração de conceitos ao movimento da Ciência Viva que busca constantemente novas respostas para os problemas que se apresentam e à proposta de Sequência Didática, a partir de uma questão problema esta articulação pode ser assim resumida nas próprias palavras de Vigotski (2010, p.154):

O conceito não leva uma vida isolada, não é uma formação fossilizada e imutável, mas sempre se encontra no processo mais ou menos vivo e mais ou menos complexo de pensamento, sempre exerce alguma função de comunicar, assimilar, entender e resolver algum problema. (Grifo nosso)

As características de um tipo de pensamento por conceitos como já mencionado anteriormente em que exigem a discriminação, a abstração, o isolamento e o exame de determinados elementos fora do vínculo concreto e factual em que são dados na experiência não são próprios dos adolescentes, aliás, o próprio Vigotski (2010, p. 180) afirma que a linguagem dos adultos está repleta de resíduos de tipos de pensamentos diferentes de um pensamento por conceitos.

Para Vigotski (2010, p.174) há um desenvolvimento em três estágios que por sua vez se subdividem em outras fases até culminarem no pensamento por conceitos em que 
destacaremos alguns dos aspectos focalizando como os significados e usos das palavras apoiam tal desenvolvimento.

O primeiro estágio, chamado por Claparède (1873-1940) como "sincretismo da percepção infantil" ou como Blonski (1884-1941) de "nexo desconexo do pensamento infantil" pode ser identificado em crianças pequenas que, frente a algum problema se veem diante de um "amontoado de objetos" e que não conseguem estabelecer relações entre eles:

Nesse estágio de desenvolvimento, o significado da palavra é um encadeamento sincrético não enformado de objetos particulares que, nas representações e na percepção da criança estão mais ou menos concatenados em uma imagem mista. Na formação dessa imagem cabe o papel decisivo ao sincretismo da percepção ou da ação infantil, razão por que essa imagem é sumamente instável. (VIGOTSKI, 2010, P. 175)

Nesta etapa criança e adulto conseguem se entender, pois a criança se utiliza do significado da palavra para o mesmo objeto concreto, sem que isto corresponda internamente a um nexo objetivo e sim a uma série sincrética dos objetos que por meio de um período de provas e erros no pensamento infantil e das percepções da disposição espacial das figuras principalmente no campo visual se estabelecem até que este amontoado de objetos não é mais suficiente para o significado das palavras que pelas experiências culturais complexifica projetando-a para o estágio posterior chamado de formação de complexos.

O pensamento por complexos seria um tipo de pensamento anterior ao pensamento por conceitos em que é caracterizado por:

(...) complexos objetos particulares concretos, não mais unificados à base de vínculos subjetivos que acabaram de surgir e foram estabelecidos nas impressões da criança, mas de vínculos objetivos que efetivamente existem entre tais objetos. (...) em vez do "nexo desconexo" que serve de base à imagem sincrética, a criança começa a unificar objetos homogêneos em um grupo comum, a complexificá-los já segundo as leis dos vínculos objetivos que ela descobre em tais objetos. (VIGOTSKI, 2010, p.179)

No pensamento por complexos, diferentemente da etapa anterior do pensamento do nexo desconexo, os atributos concretos e factuais dos objetos já estão dados externamente à criança identificado por Vigotski (2010) em tipos:

- Tipo associativo - a criança nomeia um objeto que deixa de ter um nome isolado para ser associado a um complexo que pode ser comparado a famílias de objetos.

- Tipo por coleções - a criança nomeia os objetos pelos vínculos estabelecidos pela experiência prática, efetiva e direta. 
- Tipo em cadeias - a criança nomeia os objetos organizados em uma cadeia em que os atributos são combinados dinamicamente e temporalmente, por isso o significado das palavras se desloca de um traço a outro.

- Tipo difuso - a criança nomeia os objetos que não possuem vínculos diretos por meio do estabelecimento de grupos de imagens, mesmo que pela impossibilidade de definir seus contornos pela ausência de limites claros.

- Pseudoconceito - a criança começa a aplicar na prática e a operar com conceitos "em si" para "para os outros" antes que se desenvolva "para si". Ou seja, externamente a criança apresenta um conceito, porém internamente um complexo.

O nosso interesse investigativo quanto ao uso das palavras que foram utilizadas pelos alunos ao longo das elaborações textuais escritas com base na oralidade desenvolvida durante as aulas de aplicação de SD, cabe relacionar ao tipo de pensamento por complexo em que:

A criança não escolhe o significado para a palavra, este lhe é dado no processo de comunicação verbal com os adultos. A criança não é livre para construir os seus complexos, ela já os encontra construídos no processo de compreensão do discurso do outro. Ela não é livre para escolher os elementos concretos particulares, inclusive esse ou aquele complexo. Ela já recebe em forma pronta a série de objetos concretos generalizada por aquela palavra. (...) de maneira nenhuma a criança coincide com o adulto no modo de pensar, no tipo de operações intelectuais por meio das quais ela chega aos pseudoconceitos. (VIGOTSKI, 2010, p.196)

O percurso metodológico de identificarmos as palavras utilizadas pelos alunos na oralidade e posteriormente nas produções escritas e relacioná-las aos conceitos: "MEIOS DE TRANSPORTE”, “TRANSPORTE PÚBLICO”, e “REDE DE TRANSPORTE” nos aponta para o processo de elaboração de conceitos descrita por Vigotski, nos indicando a necessidade de introduzir a partir de palavras inicialmente desconhecidas, novos conceitos, sabendo que mesmo as utilizando, não apresentam um pensamento por conceitos e sim por complexos e alguns até por nexos desconexos.

Nossa afirmação anterior não se caracteriza por um olhar pouco otimista acerca do tipo de pensamento dos nossos alunos da Educação Básica da escola pública, se considerarmos o que o próprio Vigotski (2010, p.229) afirma sobre a etapa de desenvolvimento da estrutura de pensamento dos adolescentes:

A adolescência não é um período de conclusão, mas de crise e amadurecimento do pensamento. No que tange à forma superior de pensamento, acessível à mente humana, essa idade é também transitória, e o é em todos os outros sentidos. Esse caráter transitório do pensamento do adolescente torna-se, sobretudo nítido quando não tomamos o seu conceito em forma acabada, mas em ação e o fazemos passar por um teste funcional, 
uma vez que essas formações revelam a sua verdadeira natureza psicológica na ação, no processo de aplicação. Ao mesmo tempo, quando estudamos o conceito em ação descobrimos uma lei psicológica de suma importância, que dá fundamento à nova forma de pensamento e lança luz sobre o caráter do conjunto da atividade intelectual do adolescente e sobre o desenvolvimento da personalidade e da concepção de mundo desse adolescente.

A abordagem vigotskiana da adolescência como parte do período de conclusão do terceiro estágio da evolução do pensamento por conceito nos levou a incorporar em nossa análise as ressonâncias da importância de proporcionar aos alunos, por meio da elaboração de gênero textual nas modalidades oral e escrita, a oportunidade de aplicação do conceito potencializando formas superiores de pensamento.

Quando identificamos que 69\% das referências na elaboração textual final dos alunos passam a ser "REDE DE TRANSPORTE", conceito este considerado fundamental para a discussão da questão-problema da SD, em contrapartida aos $17 \%$ de referências ao conceito "MEIOS DE TRANSPORTE" compreendemos que a passagem de certos usos de palavras no processo de um tipo de pensamento por complexo para um tipo de pensamento por conceitos pode corresponder às:

(...) transferências de nomes para novos objetos ocorrem por associação, por contiguidade ou semelhança, isto é, não segundo a lei do pensamento lógico, mas a lei do pensamento por complexo. (...) A essência dessa transferência consiste em que a função desempenhada pela palavra, não é semântica. Aqui a palavra desempenha uma função nominativa, referencial. Ela refere, nomeia a coisa (...) a palavra não é lei de algum sentido a que esteja ligada no ato do pensamento, mas um dado sensorial do objeto, ligado por via associativa ou outra coisa sensorial percebida. (VIGOTSKI, 2010, p. 215)

Podemos afirmar que as palavras desempenham um papel fundamental no processo de elaboração dos conceitos, mas que o simples emprego de referências de palavras relacionadas a determinado conceito, como no caso de "REDE DE TRANSPORTE" não significa que os alunos o estivessem utilizando com o mesmo significado que a ciência geográfica aplica e opera ao empregá-lo para responder, explicar e comunicar dados da realidade acerca do espaço geográfico.

Para explicar nosso empreendimento na análise das palavras utilizadas pelos alunos concluímos que para um pensamento por conceito se constituir como tal é preciso que uma série de atributos seja abstraído, sintetizado e generalizado para outras situações que permitam a mesma aplicação e para isso somente com o apoio das palavras é que vamos obter o êxito de tal operação: 
É precisamente com ela (a palavra) que a criança orienta arbitrariamente a sua atenção para determinados atributos, com a palavra ela os sintetiza, simboliza o conceito abstrato e opera como lei suprema entre todas aquelas criadas pelo pensamento humano. (...) A palavra é um signo. Esse signo pode ser aplicado de diferentes maneiras. Pode servir como meio para diferentes operações intelectuais, e são precisamente essas operações intelectuais, e são precisamente essas operações, realizadas por intermédio da palavra, que levam à distinção fundamental entre complexos e conceito. (VIGOTSKI, 2010, p. 226-227)

Por fim, destacamos um aspecto que consideramos de extrema importância quanto ao papel da ciência, em especial defesa da Geografia no currículo escolar para a formação biopsicossocial dos sujeitos se queremos contribuir para que possam desenvolver o pensamento por conceitos, pois, por suas características exige operações intelectuais além do nível imediato das necessidades do cotidiano como explica o próprio Vigotski (2010, p.229):

(...) os próprios conceitos do adolescente e do adulto, uma vez que sua aplicação se restringe ao campo da experiência puramente cotidiana, frequentemente não se colocam acima do nível dos pseudoconceitos e mesmo tendo todos os atributos de conceitos do ponto de vista da lógica formal, ainda assim são conceitos do ponto de vista da lógica dialética e não passam de noções gerais, isto é, de complexos.

Tivemos a oportunidade de articular os dados sobre as palavras utilizadas pelos alunos na oralidade e nos textos escritos, relacionadas aos conceitos envolvidos com a questão problema da SD, com a abordagem vigotskiana do desenvolvimento do pensamento por conceitos e que nos indicam aspectos acerca da importância da oralidade enquanto parte do gênero discursivo aula, do papel das palavras-chave que circulam e acompanham as atividades da SD e a relevância de um planejamento que contemple com clareza os conceitos com os quais se pretende que os alunos operem.

\subsection{A contribuição do gênero discursivo oral para a evolução do pensamento com leitura e escrita nas aulas de Geografia}

Entre os critérios de análise de nossa pesquisa está a contribuição do gênero discursivo oral com suas características próprias para a evolução do pensamento com a leitura e a escrita nas aulas de Geografia.

Do ponto de vista metodológico buscamos verificar, nas três elaborações textuais dos alunos, traços da oralidade e ou características dos gêneros discursivos primários, ou seja aqueles formados “(...) nas condições da comunicação discursiva imediata” (BAKHTIN, 2010, p. 263) e que assim descaracterizariam o gênero secundário, enquanto pertencente à 
esfera discursiva acadêmica; porém destacamos por meio do trabalho de Marcuschi (2001, p.76), a seguinte ideia:

Com efeito, nem tudo é tão mecânico como parece. Também não se podem postular processos lineares, pois a questão é complexa e não há critérios seguros para se dizer o que pode ficar, o que deve sair ou o que deve mudar num texto falado para assegurar patamares aceitáveis da presença da oralidade na escrita. Será inevitável que muitas marcas da oralidade não sejam sentidas como tais no texto escrito. Por outro lado, a depender do gênero textual e dos fatores lembrados (propósito, gênero, condições de produção etc.) haveria uma perspectiva diversa na retextualização.

Como afirma Marcuschi, ao tratarmos da presença de traços da oralidade e/ou características dos gêneros discursivos primários nos textos escritos dos alunos, não encontramos critérios seguros, devido à complexidade da retextualização, que segundo o autor constitui-se como: a passagem de uma modalidade de texto para outra ou de um gênero para outro.

Gráfico 8 - Contribuição da oralidade para a evolução do pensamento com leitura e escrita nas aulas de Geografia

- Apoia-se em elementos estáveis do gênero desde a primeira elaboração escrita, no que diz respeito à ausência de traços da oralidade no texto escrito. (15 alunos)

- Passa a utilizar-se de elementos estáveis do gênero discursivo- textual da modalidade escrita depois do debate, ou seja na elaboração textual final. (13 alunos)

- Não apresenta mudanças quanto à presença de traços da oralidade nas elaborações textuais, após participação no Debate. (15 alunos)

- Passa a utilizar-se de elementos estáveis do gênero discursivo- textual da modalidade escrita à partir da elaboração intermediária, ou seja, antes do Debate (02 alunos)

- Há uma variação quanto à presença da oralidade entre as três elaborações indicando que em uma delas houve algum tipo de mediação da professora e/ou de algum colega durante o processo de elaboração textual escrita. (08 alunos)

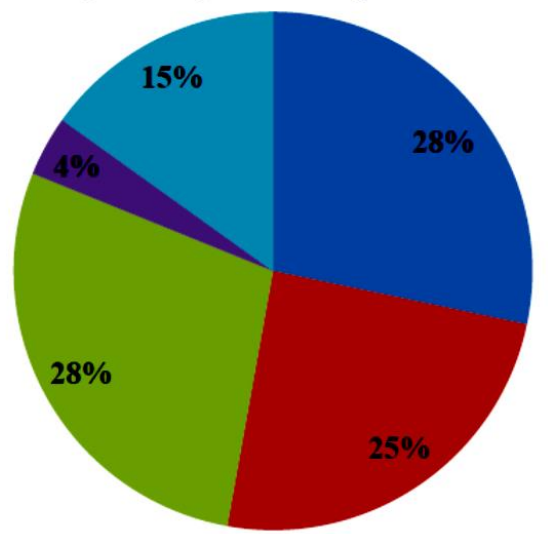

Fonte: Elaboração Ketlin E.T.W. Fiocco

Organizamos os dados de nossa análise no gráfico 8 , em que pese os desafios da ausência dos critérios seguros, a partir das três elaborações textuais dos alunos em 5 (cinco) categorias que nos apoiaram na compreensão das particularidades de cada uma das 
modalidades quando temos $28 \%$ dos alunos (15 alunos) que desde o primeiro texto já iniciam o processo de estudo da SD diferenciando as modalidades oral e escrita.

Sobre as particularidade de cada uma das modalidades textuais foi possível observar que $25 \%$ dos alunos (13 alunos) passaram a diferenciar aspectos da oralidade e dos gêneros discursivos primários em seus textos escritos depois do Debate Regrado que, mesmo de maneira experimental na aula de Geografia, com a explicitação dos elementos estáveis, por exemplo, afirmam nossa hipótese sobre um dos aspectos da importância de se garantir no Ensino a presença sistemática de gêneros discursivo-textuais orais, passando a beneficiar cada vez mais alunos.

Outro dado que apoia a análise das particularidades de cada uma das modalidades foi de que $15 \%$ dos alunos (08 alunos) em algum momento da elaboraçao textual por meio da Zona das Possibilidades Imediatas, ou seja, por meio de nossa mediação ou de algum colega da turma, apresentou algum avanço na compreensão dos elementos que caracterizam cada uma das modalidades e dos gêneros.

Considerando que as três categorias, relacionadas às particularidades de cada uma das modalidades, bem como dos diferentes gêneros tratados, como dissertação e Debate Regrado, somam $68 \%$ de nossa amostra, podemos afirmar o quão relevante, do ponto de vista da necessidade de conhecimentos do professor que vai além daqueles próprios da disciplina, relacionados às características de cada uma das modalidades, oral e escrita, bem como dos elementos estáveis do gênero textual, para que possam apoiar os alunos na organização do pensamento e na expressão dos próprios enunciados.

Sobre os aspectos interativos entre as modalidades, oral e escrita, contrariando a insistência da ideia do desenvolvimento das competências de leitura e escrita como fator determinante para que os alunos alcancem melhores resultados de proficiência, observamos que 28\% (15 alunos) continuam a apresentar aspectos da oralidade e do gênero discursivotextual primário em suas produções textuais, mesmo depois do Debate Regrado, configurando assim, a afirmação de que a oralidade enquanto gênero discursivo-textual e enquanto modalidade não pode ser ignorada, abandonada ou excluída do ensino, sobretudo quando se sabe o quanto se faz presente durante todo o processo de aprendizagem, de um modo geral. Os dados confirmam a afirmação de Marcuschi (2001, p.46): “(...) Fala e escrita são diferentes, mas as diferenças não são polares e sim graduais e contínuas”.

Pesquisas da própria neurociência (DEHAENE e COHEN, 2007), realizadas por meio de imagens de Ressonância Magnética, apontam que do ponto de vista evolutivo, a espécie humana ainda não possui estruturas cerebrais especializadas para a leitura e escrita, ao 
contrário da fala; e que para isso, áreas do cérebro preexistentes e dedicadas a outras funções, são ativadas para estas habilidades e passam a se relacionar com outras áreas do cérebro, como a da linguagem falada e a identificação de símbolos, por serem altamente plásticas.

Dehaene e Cohen (2007, p. 384) propõem a "hipótese de reciclagem neuronal", segundo a qual as invenções culturais invadem evolutivamente circuitos cerebrais mais velhos, do ponto de vista da evolução cerebral, que herdam muitas das suas limitações estruturais, porém a característica plástica do nosso cérebro possibilita que habilidades, como a leitura e a escrita, sejam desempenhadas por tais estruturas.

Morais (2013, p. 3) também considera em seu trabalho sobre a importância da formação de leitores para a construção da democracia, da universalização da literacia ${ }^{61}$ e de uma cultura baseada no pensamento livre e crítico, aspectos da evolução biológica do nosso cérebro:

Todas essas diferenças resultam de a fala ser um produto da evolução biológica, ao passo que os sistemas de escrita são artefatos. A criança foi preparada pela evolução para a linguagem oral, para compreendê-la e para produzi-la, mas não para ler e escrever. No entanto, a aprendizagem e o ensino da leitura e da escrita podem e devem fundar-se nos laços que as unem à linguagem oral. Os sistemas de escrita, e o alfabeto em particular, foram criados aproveitando constituintes estruturais e processos da linguagem oral, um mecanismo que em biologia foi chamado de "exaptação".

A partir das contribuições da neurociência, é possível constatar a ligação de áreas do cérebro que evolutivamente já possuem a estrutura para a fala e não para a leitura e a escrita, porém estritamente relacionadas, uma vez que as exigências culturais de uma sociedade letrada exigem que novos caminhos neurais sejam encontrados para que as habilidades leitora e escritora sejam desempenhadas em uma dinâmica reversiva como explica Dehaene (2013, p. 151):

(...) os experimentos comprovam que a aprendizagem da leitura, mesmo quando por adultos ex-analfabetos, tem um efeito reversivo sobre as áreas onde se realiza o processamento da língua oral, tanto no que diz respeito ao tratamento da representação fonológica (planum temporale), quanto ao dos gestos motores fono-articulatórios (regiões frontais) e ao dos significados (...)."

\footnotetext{
${ }^{61}$ A palavra "literacia" recobre dois sentidos, o de capacidade para ler e escrever, e o de uso produtivo dessa capacidade. (MORAIS, 2013, p. 8)
} 
Figura 7 - Ativação cerebral causada por frases escritas.

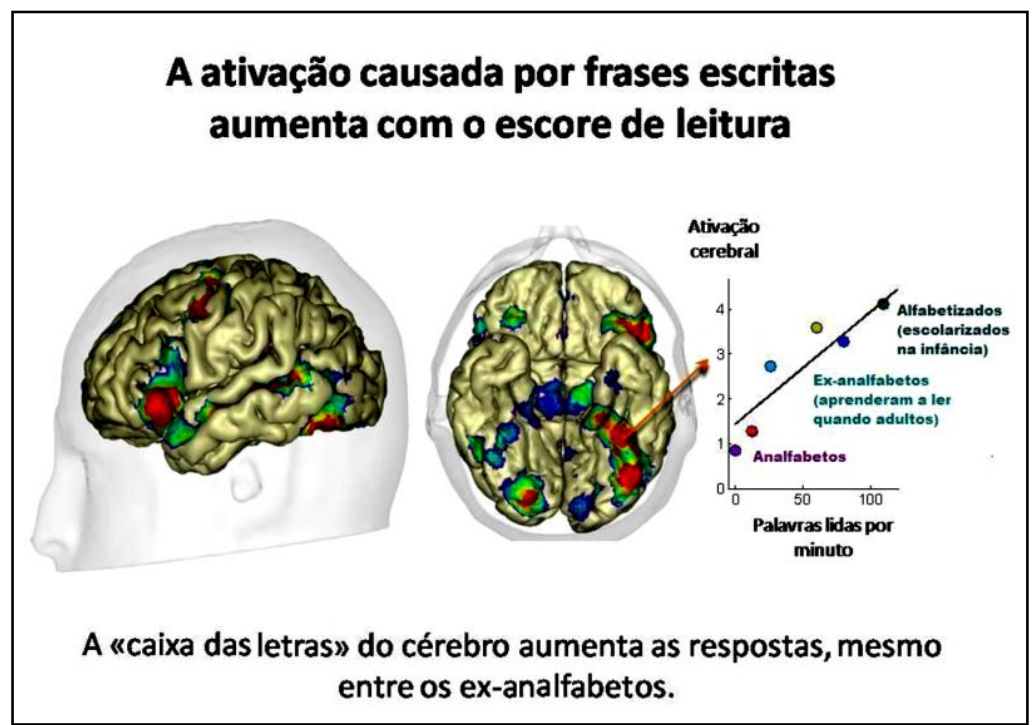

Fonte: DEHAENE, Stanislas. Letras de Hoje, Porto Alegre, v. 48, n. 1, p. 148-152, jan./mar. 2013.

As figuras 7 e 8 ilustram as principais ativações no cérebro ocasionadas pela leitura de palavras escritas e a dinâmica reversiva entre as áreas da fala e os circuitos neurais utilizados para a leitura e escrita, marcados pela plasticidade do nosso cérebro.

Figura 8 - Principais mudanças induzidas pela aprendizagem da leitura e da escrita.

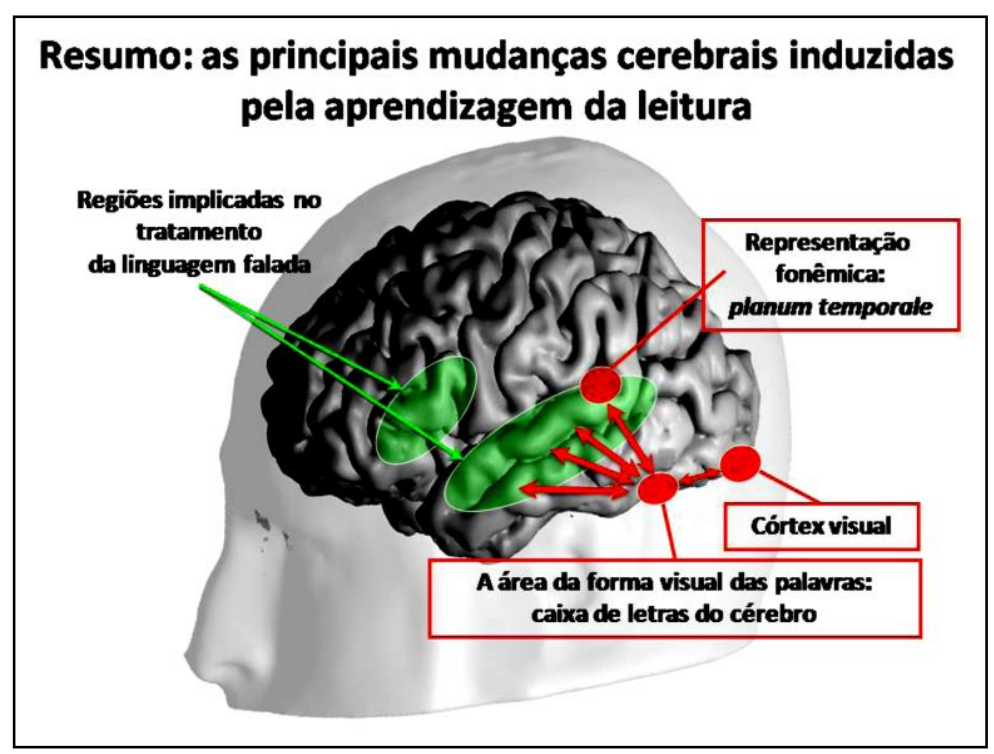

Fonte: DEHAENE, Stanislas. Letras de Hoje, Porto Alegre, v. 48, n. 1, p. 148-152, jan./mar. 2013. 
A característica plástica do nosso cérebro foi identificada anteriormente por Feuerstein et. al. (2002) que elaborou a sua Teoria da Modificabilidade Cognitiva Estrutural ${ }^{62}$ com base $^{2}$ em pesquisas com crianças vítimas do holocausto na segunda Guerra Mundial (1939-1945) em que:

(...) baseia-se na modificabilidade, na flexibilidade da estrutura cognitiva, e tem como um dos aportes conceituais centrais o pressuposto de que o ser humano é dotado de uma mente plástica, flexível, aberta a mudanças, assim como dotada de um potencial e de uma propensão natural para a aprendizagem. (GOMES, 2002, p.66)

Tanto a Teoria da Modificabilidade Estrutural Cognitiva de Feuerstein, quanto a hipótese de reciclagem neuronal de Dehaene partem do pressuposto que o contexto cultural, por meio da aprendizagem mediada, exerce influência nas modificações estruturais e transformações do modo de pensar dos sujeitos; para além da maturação biológica.

Para traçarmos ações mais prospectivas para um ensino na perspectiva de aprendizagens mediadas, se faz necessário conhecer as operações mais comuns realizadas na passagem do texto falado para o texto escrito, ou de um gênero textual para outro, ou seja, para a retextualização, começamos pela atividade cognitiva de compreensão, como explica Marcuschi (2001, p. 47):

Há nessas atividades de retextualização um aspecto geralmente ignorado e de uma importância imensa. Pois para dizer de outro modo, em outra modalidade ou em outro gênero o que foi dito ou escrito por alguém, devo inevitavelmente compreender o que foi que esse alguém disse ou quis dizer. Portanto, antes de qualquer atividade de transformação textual, ocorre uma atividade cognitiva denominada compreensão. Esta atividade, que em geral se ignora ou se dá por satisfeita e não problemática, pode ser a fonte de muitos problemas no plano da coerência no processo de retextualização. (...) mas a questão mereceria um estudo bem mais aprofundado, tendo em vista sua relevância (Grifo do autor).

Mesmo concordando com o autor acerca da necessidade de estudos e pesquisas mais aprofundados sobre o processo de compreensão envolvido em atividades de retextualização lançamos mão do modelo das operações textuais-discursivas do texto oral para o texto escrito, em que Marcuschi apresenta em um diagrama, que pode ser sintetizado da seguinte forma:

(...) o modelo exposto (...) (Figura 9) corresponde a uma escala contínua de estratégia, desde os fenômenos mais próximos e típicos da fala até os mais específicos da escrita. O domínio da escrita vai se manifestando,

\footnotetext{
${ }^{62}$ A Teoria da Modificabilidade Cognitiva Estrutural já foi citada no capítulo 2, p. 80-88 quando abordamos "A expressão oral como elemento para a formação de sujeitos na aula de Geografia" em que afirmamos que a escola, especialmente as aulas podem contribuir por meio da aprendizagem mediada possibilidades de funcionamento e estruturação do pensamento e da dimensão cognitiva indispensáveis à formação de sujeitos criadores de relações de dependências criativas com a cultura em que estão inseridos.
} 
progressivamente, de acordo com as estratégias que vão sendo realizadas. As quatro primeiras operações contêm as estratégias mais comuns, quase espontâneas, revelando serem intuitivamente estes os aspectos percebidos como mais salientes na diferença entre fala e escrita, tendo em vista a visão dicotômica na relação fala-escrita proporcionada pela escola. A dicotomia funda-se numa sensação de descontinuidade da superfície e não em estratégia de formulação linguística. (MARCUSCHI, 2001, p.76. Grifo do autor.)

Ainda que o modelo das operações textuais-discursivas do texto oral para o texto escrito apresente aspectos muito específicos de atividades que se caracterizam como próprias das aulas de Língua Portuguesa julgamos relevantes conhecê-las para que se tornem ferramentas de mediação de trabalhos futuros, não só das aulas de Geografia, mas de todos os professores que se disponham apoiar os alunos nas aquisições de leitura e escrita e, por conseguinte, o desenvolvimento da oralidade.

Por fim, destacamos que ao optarmos pelo título desta seção por: “A contribuição do gênero discursivo oral para a evolução do pensamento com leitura e escrita nas aulas de Geografia" destacamos que:

Em hipótese alguma se trata de propor a passagem de um texto supostamente "descontrolado e caótico" (o texto falado) para outro "controlado e bem formado" (o texto escrito). Fique claro, desde já, que o texto oral está em ordem na sua formulação e no geral não apresenta problemas para a compreensão. Sua passagem para a escrita vai receber interferências mais ou menos acentuadas a depender do que se tem em vista, mas não por ser a fala suficientemente organizada. Portanto, a passagem da fala para a escrita não é a passagem do caos para a ordem: é a passagem de uma ordem para outra ordem. (MARCUSCHI, 2001, p. 47, grifo do autor)

No sentido de estabelecer ordens distintas para as modalidades, escrita e oral dos gêneros textuais reiteramos por meio das ideias de Marcuschi que a evolução do pensamento com leitura e escrita que nos referimos nesta seção de nossa análise, diz respeito às características do pensamento por conceitos, retomando assim, a problematização de nossa pesquisa sobre a importância da oralidade para a elaboração de conceitos na aula de Geografia e que se configura por meio das análises teóricas e metodológicas do plano empírico. 
Figura 9 - Modelo das operações textuais-discursivas do texto oral para o texto escrito.

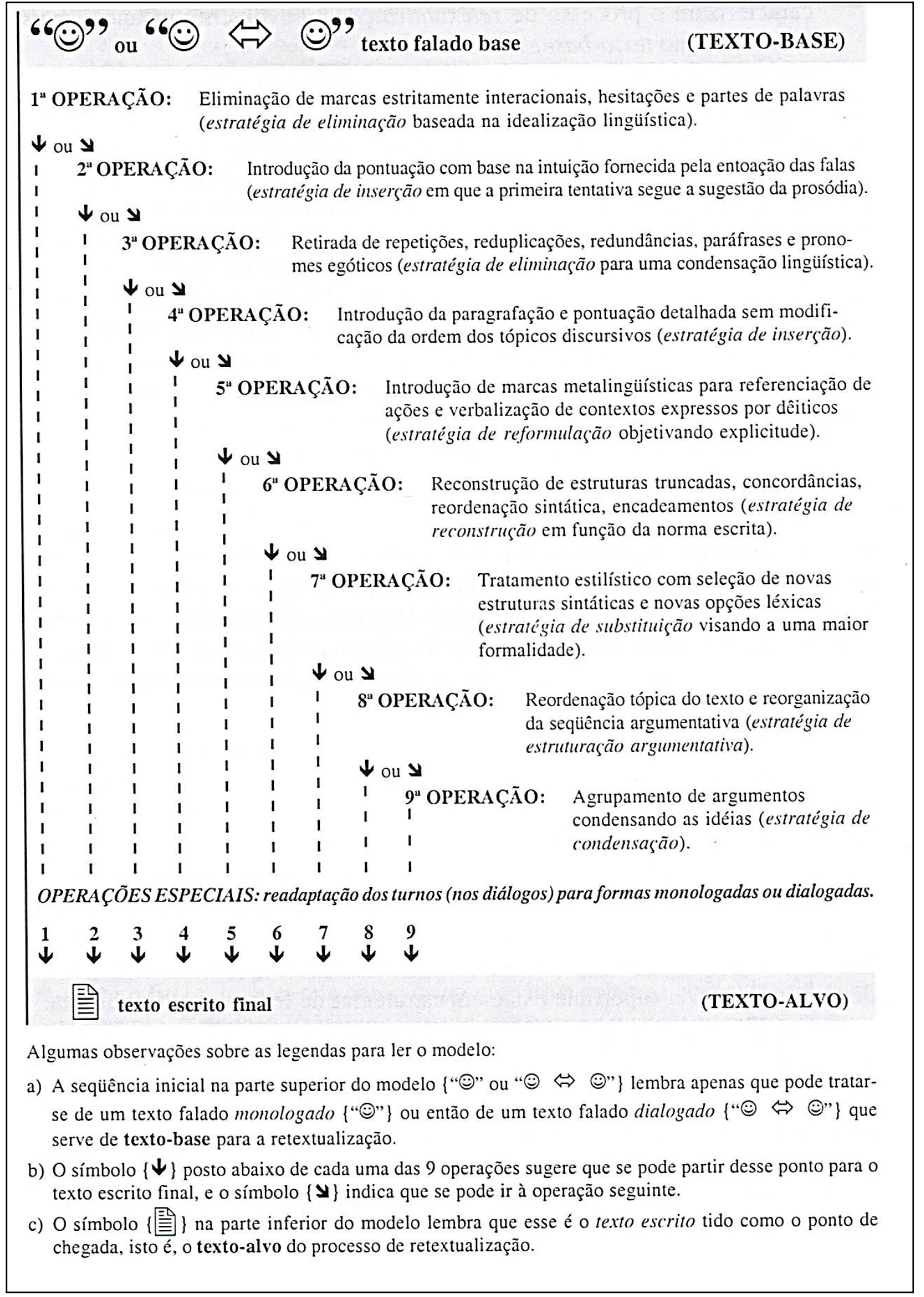

Fonte: Marcuschi, 2001, p.75. 


\section{Capítulo 4. A aprendizagem mediada do Debate Regrado na aula de} Geografia: o desafio de ensinar a oralidade na ação

Figura 10 - Alunos participantes do $2^{\circ}$ turno do Debate Regrado, $7^{\circ}$ Ano B, Novembro, 2013.

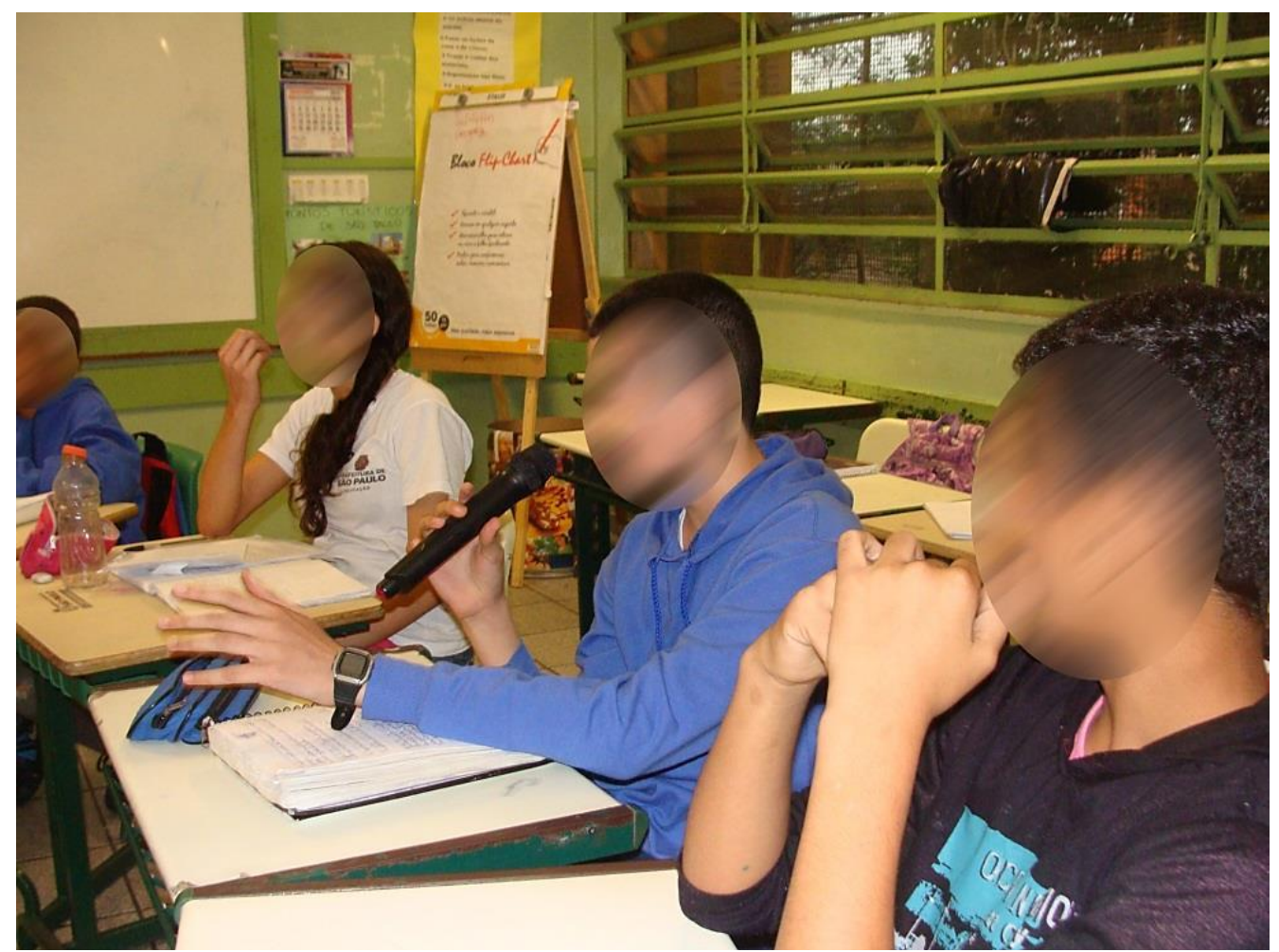

Fonte: Acervo de pesquisa da SD "O Brasil vai de que". (Fotografia tirada por um dos alunos participantes da pesquisa, novembros 2013).

Como já afirmamos anteriormente ao planejarmos as Sequências Didáticas (SD) de Geografia por gêneros discursivo-textuais (Quadro 4), nos deparamos com a necessidade de organizar, em todas elas, atividades de linguagem verbal oral, principalmente na versão Debate Regrado, inicialmente com foco na aprendizagem da comunicação e expressão de ideias, opiniões e posicionamentos sobre determinado tema de estudo, compreendendo assim, que tal atividade seria fundamental para o aprendizado da ciência, o desenvolvimento da capacidade da linguagem argumentativa e a formação do pensamento crítico de nossos alunos.

O Debate Regrado na SD “O Brasil vai de quê?" constituiu-se como uma das atividades do módulo 4 e tinha como objetivo inicial potencializar os posicionamentos e a capacidade de argumentação dos alunos acerca do problema proposto antecedendo a elaboração textual final que seria a atividade conclusiva da aplicação da SD.

Organizamos a participação dos alunos de modo que todos tivessem uma função durante cada um dos turnos do debate, como o grupo de debatedores: um cronometrista, um 
mediador e seus auxiliares, um assistente de microfone, um cinegrafista, um fotógrafo, um aluno para registrar quantidades de intervenções dos colegas durante os turnos de falas e o restante dos alunos como a plateia, que ao fim do turno também poderiam fazer perguntas.

Figura 11 - Alunos participantes do $2^{\circ}$ turno do Debate Regrado, $7^{\circ}$ Ano B, Novembro, 2013.

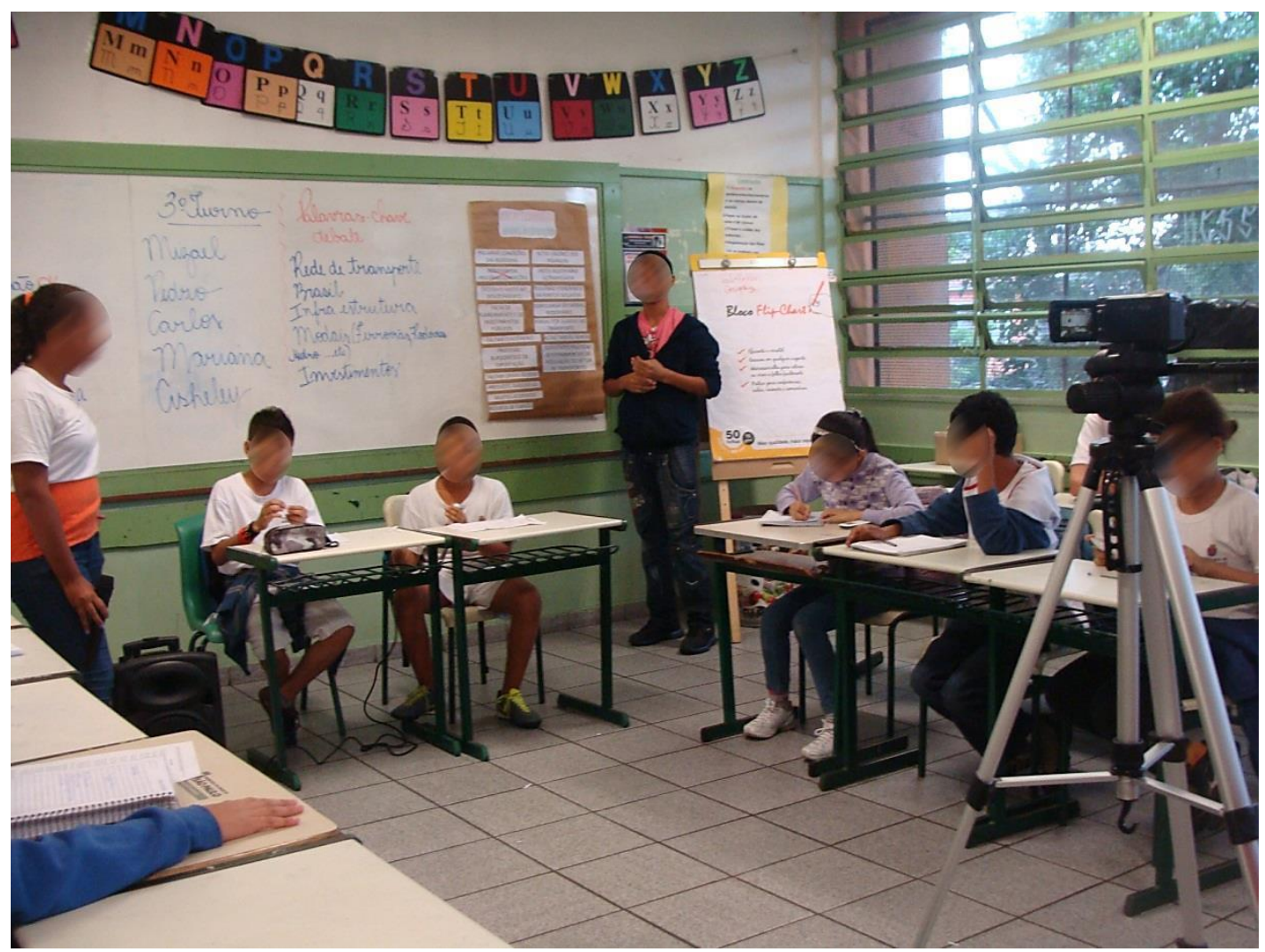

Fonte: Acervo de pesquisa da SD "O Brasil vai de que". (Fotografia tirada por um dos alunos participantes da pesquisa, novembros 2013).

Durante a realização dos turnos de Debate tivemos ao todo 64 participantes, o que corresponde a $83 \%$ do número total de alunos envolvidos na aplicação da SD; sendo que 42 alunos $(67 \%)$ possuem alguma fala transcrita que compõem parte do acervo do material empírico da nossa pesquisa e também com registro audiovisual. 
Gráfico 9 - Alunos participantes do Debate Regrado da SD "O Brasil vai de quê?"

\section{Alunos participantes do Debate Regrado com fala transcrita}

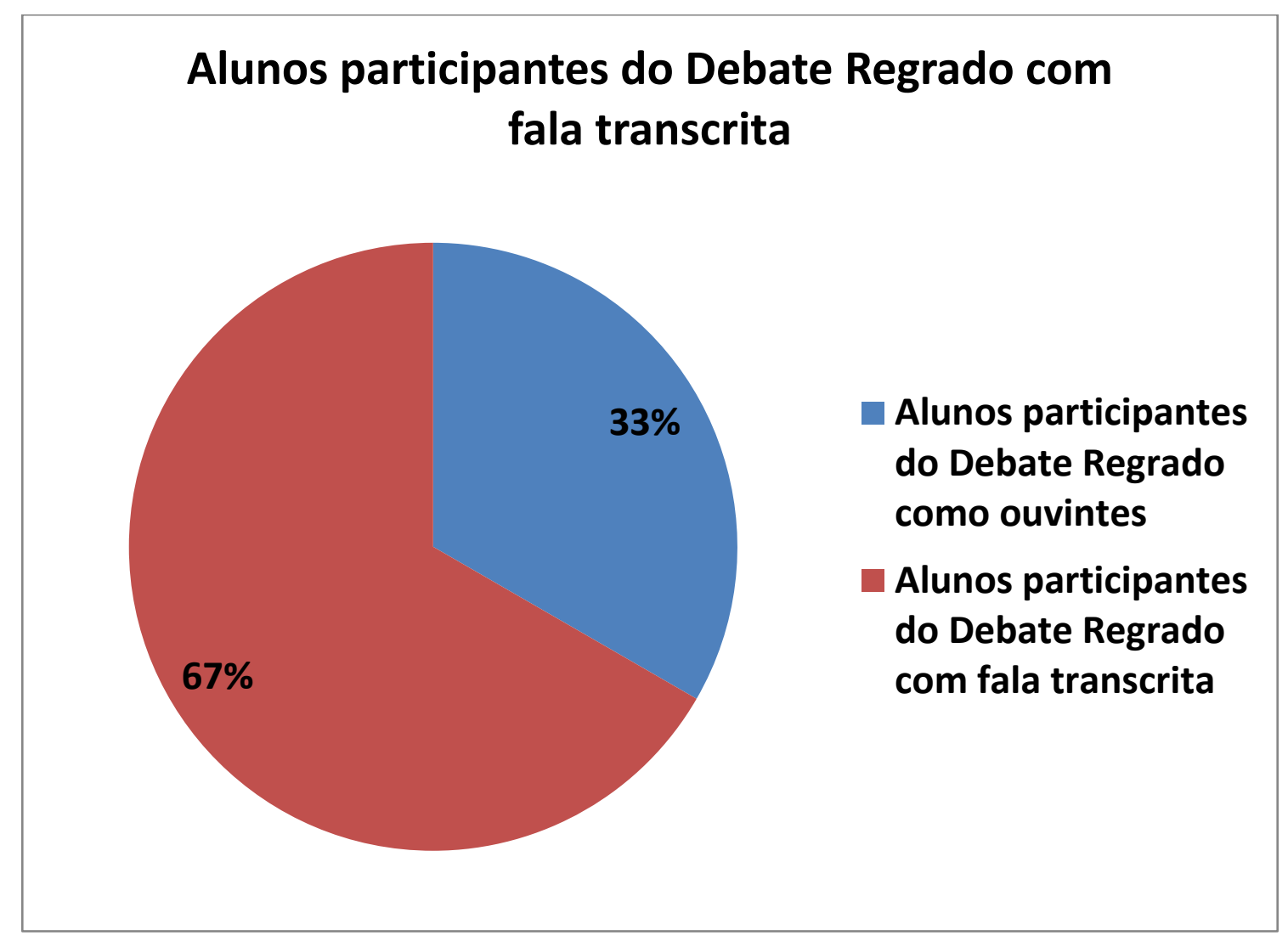

Fonte: Elaboração Ketlin E. T. W. Fiocco.

$\mathrm{Na}$ amostra válida dos dados de 53 alunos com as três elaborações textuais escritas e a elaboração textual oral, temos 38 alunos com falas transcritas o que corresponde a $72 \%$ da amostra.

A porcentagem de mais de $70 \%$ de alunos da amostra com falas transcritas possibilitou a integração de aspectos fundamentais relacionados à importância de garantirmos a participação dos alunos em atividades que envolvam a oralidade enquanto gênero discursivotextual considerando os desafios de uma escola que ainda não garante os espaços efetivos para o desenvolvimento da oralidade dos alunos.

A afirmação pode parecer um tanto quanto contraditória quando confrontamos com a realidade de turmas de adolescentes que, em geral, são extremamente eloquentes e vivazes na expressividade oral para assuntos relacionados ao cotidiano e de seus interesses mais imediatos e, portanto, mais próximos da exigência de um pensamento por complexos.

Do ponto de vista do cotidiano e dos aspectos comunicacionais, os adolescentes via de regra, já apresentam o domínio da oralidade, e desse modo necessitam de oportunidades estruturadas para que elaborem gêneros textuais orais públicos, como afirmam Schneuwly e Dolz (2010, p. 146-147): 
A prioridade dada aos gêneros públicos formais não decorre somente de razões pedagógicas, mas também psicológicas e didáticas. Os alunos geralmente dominam bem as formas cotidianas de produção oral. Elas funcionam como reação imediata à palavra de outros interlocutores presentes e podem ser consideradas como autorreguladas, à medida que o funcionamento de linguagem constitui-se, em grande parte, graças a seu próprio desdobramento. (...) O papel da escola é levar os alunos a ultrapassar as formas de produção oral cotidianas para os confrontar com outras formas mais institucionais, mediadas, parcialmente reguladas por restrições exteriores.

Ao nos voltarmos para as gravações, bem como para as transcrições das falas realizadas nos turnos de Debate Regrado, percorremos o caminho de análise de uma atividade inserida no contexto de uma Sequência Didática, ou seja, o Debate Regrado que se constituiu como parte do processo complexo de ensino e aprendizagem de uma temática de Geografia com conteúdos organizados numa lógica que deveria favorecer a aprendizagem dos alunos de um fenômeno complexo acerca do espaço.

Assim, como Schneuwly e Dolz (2010, p. 213) no relato da elaboração de uma Sequência Didática de um Debate Regrado em que afirmam:

“(...) esforçamo-nos também em pensar e racionalizar a posteriori uma prática inicialmente bastante intuitiva, em particular no que se refere a seus enquadres e suas implicações, de maneira a colocarmos em evidência as questões a serem levantadas para construir uma sequência do ensino do oral."

Orientamos nosso trabalho conforme os autores quanto à potencialidade da aplicação do Debate Regrado na aula de Geografia resultando em análises e reflexões a posteriori, devido ao trabalho da própria pesquisa articulando-se a outras contribuições teóricas em nossa análise. O ensino específico da oralidade ampliou a elaboração textual na ação do ensino de Geografia de caráter experimental e por isso com aspectos diferentes das preocupações do ensino da língua.

Neste processo de análise específica da fala dos alunos, inicialmente nos detivemos somente ao aspecto caótico da oralidade o que nos possibilitou:

(...) a somente ver hesitações, titubeios, reformulações, retomadas ecoicas, balbucios, falsos inícios e, suspiros de todo tipo, em falsas cadências, fáticos onipresentes, início de turnos abortados, quebras, interrupções, latidos que a frase canônica Sujeito-verbo-objeto é um fenômeno singular e, portanto, notável e notado. (SCHNEUWLY e DOLZ, 2010, p. 132)

Os aspectos caóticos do texto oral também foram observados ao lermos as transcrições que realizamos do Debate Regrado e igualmente assumimos que: 
(...) era enorme o descompasso existente entre nossas expectativas, ligadas à nossa relação com a escrita, e a realidade das produções. (...) às vezes temos dificuldade de ler o que foi dito... (...) Logo, foi suficiente escutar em vez de ler, para começar a modificar nossa maneira de apreender as produções orais. (SCHNEUWLY e DOLZ, 2010, p. 132-133)

Indicamos a seguir os turnos de fala em que é possível constatar as hesitações a que Schneuwly e Dolz se referem, mas também outros critérios de análise, como os elementos estáveis do gênero, o Tema/Assunto/Conteúdo da SD e a argumentação:

Quadro 12 - Exemplo I de turnos de falas dos alunos no Debate Regrado da SD “O Brasil vai de quê?"63

\begin{tabular}{|c|c|c|}
\hline TURNOS & FALAS TRANSCRITAS & $\begin{array}{l}\text { CRITÉRIOS DE } \\
\text { ANÁLISE } \\
\end{array}$ \\
\hline \multirow{15}{*}{ 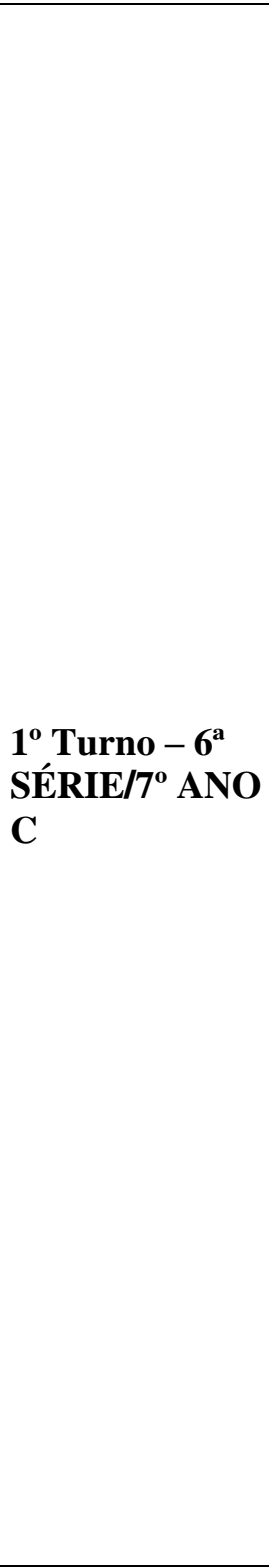 } & $\begin{array}{l}\text { Aluna } 38 \text { - Ó (risos) agora vou fazer o sorteio } \\
\text { para ver quem vai fazer pergunta pra quem e } \\
\text { (risos)... }\end{array}$ & $\begin{array}{l}\text { Elementos estáveis do } \\
\text { gênero }\end{array}$ \\
\hline & $\begin{array}{l}\text { Professora - Aluna 38, primeiro, primeiro, } \\
\text { primeiro as pessoas têm que apresentar o seu } \\
\text { ponto de vista. Então você vai sortear a ordem } \\
\text { das apresentações, tá? Então quem vai ser } \\
\text { primeiro a apresentar? Vai ajudando ela Aluna } \\
40 .\end{array}$ & $\begin{array}{l}\text { Elementos estáveis do } \\
\text { gênero }\end{array}$ \\
\hline & Aluna 38 - Tá. & $\begin{array}{l}\text { Elementos estáveis do } \\
\text { gênero }\end{array}$ \\
\hline & Plateia - Professora! & \\
\hline & $\begin{array}{l}\text { Plateia - (incompreensível) último, a gente } \\
\text { (incompreensível) último. }\end{array}$ & \\
\hline & $\begin{array}{l}\text { Aluna } 40 \text { - O nome da pessoa é (em tom bem } \\
\text { baixo)(risos) (devolveu o microfone para a } \\
\text { Aluna 38) }\end{array}$ & \\
\hline & $\begin{array}{l}\text { Aluna } 38 \text { - Agora...quem saiu na minha mão é o } \\
\text { Aluno } 53 \text {. }\end{array}$ & $\begin{array}{l}\text { Elementos estáveis do } \\
\text { gênero }\end{array}$ \\
\hline & $\begin{array}{l}\text { Professora - O Aluno } 53 \text { vai fazer a primeira } \\
\text { pergunta sobre o tema. }\end{array}$ & $\begin{array}{l}\text { Elementos estáveis do } \\
\text { gênero }\end{array}$ \\
\hline & Plateia - Iuuuuuu. (incompreensível) & \\
\hline & $\begin{array}{l}\text { Professora - Devolve, devolve (pedindo o } \\
\text { microfone de volta). }\end{array}$ & \\
\hline & Aluno 53 - Não. & \\
\hline & Professora - Leia a pergunta pra ele de novo & $\begin{array}{l}\text { Tema/Assunto/Conteúdo } \\
\text { da SD }\end{array}$ \\
\hline & Aluno 53 - Não. & \\
\hline & $\begin{array}{l}\text { Professora - E você vai RESPONDER essa } \\
\text { pergunta. Todo mundo vai falar o seu ponto de } \\
\text { vista. A gente começa com o ponto de vista. Tá } \\
\text { bom? Vai Aluna } 38 \text {. }\end{array}$ & Argumentação \\
\hline & Aluna 38 - A exemplo de muitos países & Tema/Assunto/Conteúdo \\
\hline
\end{tabular}

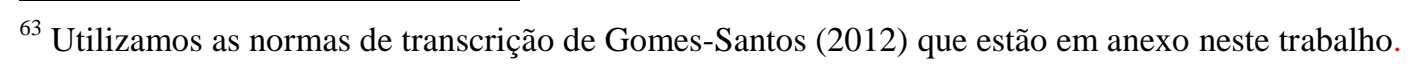




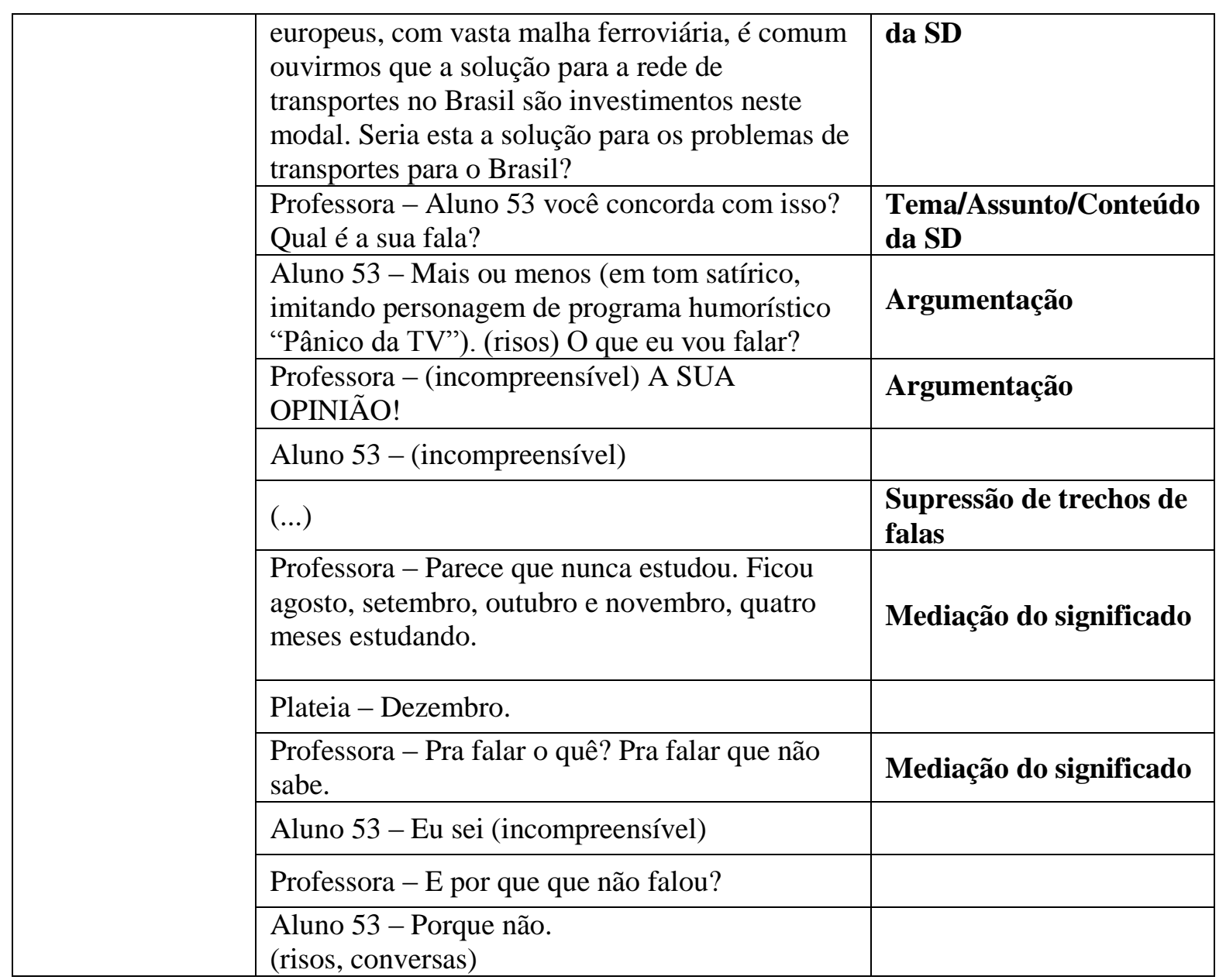

Fonte: Elaboração Ketlin E. T. W. Fiocco de acordo com a proposta de análise de Sasseron, L. H.; Carvalho, A. M. P. (2011)

A participação oral dos alunos, que a princípio demonstraram-se adversas daquelas esperadas com desenvolturas, repletas de afirmações coerentes e que demonstrassem de alguma forma um posicionamento crítico como resultado de meses de estudos, na realidade, nos apontaram as fragilidades de tais expectativas e ao mesmo tempo a necessidade de compreender o Debate Regrado como parte de um complexo processo de aprendizagem de Geografia, de regras do pensamento e do próprio gênero oral.

Nesta etapa da pesquisa reafirmamos nosso compromisso, compartilhando da visão de Santos, Mortimer e Scott, (2001, p. 284) em que afirmam:

(...) a prioridade é tornar visíveis as práticas discursivas existentes e, só então, apontar para como elas podem ser expandidas. (...) Se o objetivo do ensino é que os alunos desenvolvem uma compreensão de qualquer tema, então eles devem participar em alguma forma de atividade dialógica.

Ainda que o trecho apresentado como exemplo dos turnos de falas seja repleto de possibilidades de análises e que certamente nos levariam a rever nossa prática devido ao distanciamento tomado durante o processo de pesquisa e, dada a complexidade das relações 
que ocorrem durante a aula, nos limitamos por meio dos referenciais teóricos utilizados aqui, a apontar nos turnos das falas alguns indicadores teóricos que nos apoiassem na investigação acerca da importância da oralidade para o Ensino de Geografia: o Tema/Assunto/Conteúdo da SD; os elementos estáveis do gênero; a argumentação e a mediação da aprendizagem.

Quanto aos elementos estáveis do gênero partimos do próprio conceito de Debate Regrado que foi modificado ao longo de nossa pesquisa, pois inicialmente prevalecia a concepção de um formato muito caricatural dos modelos televisivos em que Schneuwly e Dolz (2010, p. 71) discutem:

(...) ele funciona como eventos que colocam, numa luta sem piedade, oponentes que tentam, por todos os meios - particularmente pela persuasão, pela teatralização, pelo sensacionalismo, pela verbalização de insultos e até de semi-verdades, ou, ainda, pela contradição - dominar, quiçá, ridicularizar, o adversário. A escuta deste último, por sua vez, é direcionada a encontrar falhas que permitam desarmar seu predecessor. O objetivo da empreitada é, mais do que encontrar uma resposta para uma questão, fazer triunfar, a qualquer preço, uma posição em detrimento da outra. A paralisação, a incapacidade de aprender, a falta de respeito pelo outro constituem tendencialmente, o todo desses eventos da mídia que, em parte, têm interesse, precisamente, nessa dimensão belicosa.

Esta visão de um Debate com o objetivo de derrotar o outro com o qual se discute é uma ideia que prevaleceu nas orientações que realizamos junto aos alunos e pode ser observada no instrumento que elaboramos na figura 12.

O instrumento que elaboramos não corresponde à importância da atividade do Debate Regrado no contexto da SD que, sem muita reflexão, apresenta apenas o resultado de uma rápida pesquisa na internet, o que ao contrário, demandaria uma pesquisa com elevado grau de acuidade com o objetivo de recobrir as demandas da turma quanto aos elementos estáveis do gênero.

$\mathrm{Na}$ aula anterior à realização dos turnos de debate, lemos com os alunos o texto contendo perguntas e respostas acerca do gênero Debate Regrado, como; "O que é?", "Para quê?" e "Como?", além de 6 dicas para a organização da fala, a descrição das funções do mediador e as regras gerais. $\mathrm{O}$ texto apoiou a mediação durante a atividade, sendo retomado sempre que necessário, a fim de consolidar os aspectos relacionados aos elementos estáveis do próprio gênero. 
Figura 12 - Instrumento do Debate Regrado no contexto da SD "O Brasil vai de quê?"

INSTRUMENTOS DE MEDIACÄO DA SEQUÊNCIA DIDÁTICA POR GÉNERO DISCURSTVO-TEXTUAL O BRASII VAI DE QUÊ? - EMEF GAL ALCDDES GONCALVES ETCFEGOYEN - PROFESSORA AUTORA KETUN EUSA THOMÉ WENCESLAU FOCCO - $4^{\circ}$ BIMESTRE 2013.

\section{DEBATE REGRADO}

1. O QUE É? Gênero discursivo textual oral de exposição de nossas ideias, ouvir e respeitar as ideias alheias, mesmo que diferentes das nossas.

2. PARA QUÊ? Quando debatemos, desejamos convencer nosso interlocutor de que temos razão.

3. COMO? Devemos nos esforçar para escolher argumentos persuasivos, isto é, capazes de modificar o ponto de vista de nosso interlocutor. Esse gênero, apesar de usar a modalidade oral, exige linguagem cuidada, na variedade culta e padrão, conforme o estilo escrito.

4. DICA 1: Evite falar sem ter claro o que vai dizer e como. Antes de expressar sua opinião sobre o problema da Sequência Didática, prepare-se: pesquise e anote seus argumentos.

5. DICA 2: Antes de tomar uma posição, avalie os dois lados da questão, enumerando as vantagens e desvantagens tanto de uma posição quanto de outra.

6. DICA 3: Para desenvolver e fundamentar seus argumentos, utilize exemplos, comparações, resultados de pesquisas e estatísticas, além de pensamentos ou citações de pessoas que tenham autoridade no assunto.

7. DICA 4: Para apresentar esses dados, você poderá utilizar expressões como "de acordo com os dados de uma pesquisa realizada...", "segundo o pensamento de fulano de tal..." e assim por diante. Geralmente são empregadas expressões como: penso que, do meu ponto de vista, na minha opinião, concordo, discordo, concordo em parte, etc.

8. DICA 5: Tente descobrir incoerências ou contradições nos argumentos do interlocutor. Sempre que possivel, procure se servir de dados e informações (estatisticas, pesquisas, publicações, exemplo da Histónia, comparações com realidades diferentes, citações etc.) capazes de demonstrar que o argumento do interlocutor é falso ou apenas parcialmente verdadeiro.

9. DICA 6: Evite argumentos repetidos, a fim de que o debate ganhe um bom andamento e não fique monótono.

10. FUNÇÕES DO MEDIADOR: cumprimentar o público, apresentar o tema que será debatido e falar de modo geral sobre o assunto. Iniciar e controlar os turnos de fala dos debates, controlar o tempo dos tumos de fala, controlar os "ânimos" dos debatedores (se necessário imputando a perda do turno de fala). Procurar manter a discussão dentro do tema e dos objetivos predeterminado. Para finalizar o debate, o moderador faz uma sintese dos argumentos apresentados pelos debatedores, destacando o motivo do debate e agradece a presença e participação de todos.

11. REGRAS: * número de participantes: no máximo, cinco (por turno) *distribuição do tempo: apresentação inicial de 1 minuto, duas perguntas de 30 segundos para cada grupo. *Cada pergunta será seguida de uma resposta de 1 minuto, com possibilidade de réplica de 30 segundos e tréplica de 30 segundos. * Definição das falas iniciais: cada debatedor deverá expor a sua opinião no início (1min) * Ordem inicial das questões (quem pergunta para quem): sorteio feito pelo mediador * participação do público (perguntas orais ou escritas): possibilidade de duas perguntas, orais ou escritas, direcionadas a um dos grupos (30 seg.) com resposta de lminuto; sem direito a réplica.

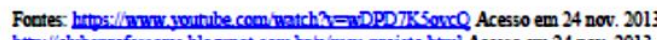

hitr: / cluberrofessores blogspot combrip/ment-projeto hrml Acesso em 24 nov. 2013

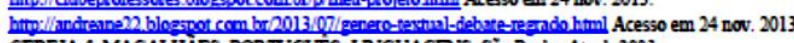

CEREJA \& MAGALHAES. PORTUGUES: INGGUAGENS. Sio Paulo: Atual, 2003.

NOBRE, Natalia. Debate regado. Disponivel em: http://www.auxiliadoradenatal.com.br/novo/pdf/18.07 Aula Debate Regrado.pdf Acesso em 24 nov. 2013.

Fonte: Elaboração Ketlin E. T. W. Fiocco.

Mesmo que nossa mediação junto aos alunos tenha contemplado a necessidade de respeitarmos as ideias contrárias, ocorreu a intensa preocupação de elaborar argumentos que desmantelassem a ideia apresentada pelos colegas que deveriam ser encarados como adversários. A crítica vem de Schneuwly e Dolz (2010, p. 71) ao questionarem: 
O que se poderia aprender desse gênero, assim praticado, e que domina, dessa maneira, as representações comuns? Não se ensinaria por meio dele uma visão da argumentação como combate em que a questão da verdade tenderia desaparecer? Em que a possibilidade de aprender e de enriquecer com o outro é negada? Em que sutis mecanismos que movimentam cada um, em função da transformação das significações de sua própria fala graças à integração dos outros, quase não são perceptíveis? Em que domina a visão da argumentação como pura técnica retórica?

O que se coloca é uma necessidade de outra concepção de Debate como instrumento coletivo de reflexão e compartilhamento de novos conhecimentos, em que os alunos possam aprender com as opiniões e informações diversas. Nesta perspectiva apontamos que o debate pode assim ser definido como:

(...) constituído pelo conjunto das intervenções - cada uma delas fornece esclarecimento à questão controversa; o debate aparece, assim, como a construção conjunta de uma resposta complexa à questão, como instrumento de reflexão que permite a cada debatedor (e a cada ouvinte) precisar e modificar sua posição inicial; essa modificação é realizada essencialmente, pela escuta, pela consideração e pela integração dos discursos do outro; cada argumento, cada exemplo, o sentido de cada palavra transformam-se, continuamente, pelo fato de serem confrontados aos dos outros debatedores, pelo fato de que cada um está continuamente, situando-se em relação às outras intervenções. (SCHNEUWLY e DOLZ, 2010, p. 72)

Ao propormos o tipo de "debate para a resolução de problemas" o articulamos às proposições de Pozo e de Vigotski quanto ao desenvolvimento de conceitos por meio de um ensino que privilegie o desafio do pensamento e não a repetição de ideias prontas e convencionalmente aceitas; e, à de Bakhtin quanto à dialogicidade que ocorre nos elos da corrente comunicacional por meio dos enunciados dos sujeitos.

Ainda sobre os elementos estáveis do gênero discursivo-textual é preciso destacar que existe uma grande dificuldade de defini-los com precisão devido às inúmeras situações em que os sujeitos os utilizam e na escola não é diferente, pois de acordo com as necessidades dos diversos aspectos para o ensino e aprendizagem é preciso fazer as adequações necessárias, entretanto, sem deixar de apresentar e de discutir com os alunos tais características.

Schneuwly e Dolz (2010, p. 234) apontam três dimensões normativas que podem apoiar a mediação da elaboração textual oral pelos alunos que são: o funcionamento comunicativo da intervenção, como a adequação ao contexto; sua coerência interna que está relacionada à estrutura e palavras ou expressões que retomam aspectos do texto e sua correção linguística, como sintaxe, morfologia e léxico.

De acordo com os autores, as mediações dos aspectos normativos podem: 
(...) estar a cargo do professor ou dos alunos. Ela pode ser imediata e interromper momentaneamente o desenvolvimento da comunicação, mas ela também pode ser retardada, ao fim da troca comunicativa, ou mesmo mais tarde, baseada numa retomada da gravação (comentário retroativo). Além disso, a intervenção pode ser feita de uma maneira integrada, implícita, por exemplo, utilizando-se a forma correta num enunciado encadeado ou respondente ao enunciado incorreto, ou de uma maneira explícita, quando o erro é tematizado como tal. (SCHNEUWLY e DOLZ, 2010, p. 234)

Reiteramos que nossa expectativa anterior relacionada ao debate de ideias por meio de argumentos elaborados pelos alunos sobre as possíveis soluções para os problemas da Rede de Transportes no Brasil, se transformou em possibilidade de mediação por meio da fala dos alunos constituída de enunciados e organizada em gêneros discursivos o que reorientou a nossa própria mediação, posterior ao debate, para que os alunos pudessem ter, com efeito, os elementos necessários para a elaboração do texto final da SD.

Retomando o turno de falas que apresentamos como exemplo no quadro 12 , identificamos apenas dois turnos que classificamos como ações de mediação do significado, no momento em que expomos, incisivamente, que depois de tanto tempo estudando não havia uma resposta condizente com o tema e até chegamos a realizar uma pergunta, mas sem aguardar o tempo necessário para a resposta do aluno que, ao fim, responde, com "porque não" para sua hesitação em participar do Debate. De acordo com Gomes, (2002, p.90) o critério de mediação do significado consiste em:

O mediador deve fornecer seus significados para o mediado, inclusive para que ele possa elaborar novos significados e novas possibilidades, generalizando e transcendendo. Interagir pela troca de significados significa trocar experiências, vivências e sentimentos que ultrapassam o nível do fenômeno concreto. Significa que, geração após geração, os seres humanos irão compartilhar e terão uma certa identificação sobre o que é certo e o que é errado, estabelecendo um senso comum, um senso estético e ético. (...) No contexto da teoria de Feuerstein "significado" deve ser entendido como um sentido que o indivíduo tira da vida.

A citação quanto à concepção de mediação do significado nos interpela sobre a necessidade de repensarmos um ensino que não privilegie a demonstração do que o aluno aprendeu, reforçando ainda uma prática de um ensino tradicional, do ponto de vista da avaliação como se o significado da atividade de Debate fosse a apresentação dos conhecimentos memorizados, ou apreendidos ao longo da aplicação da SD.

Nas transcrições e posteriores análises das gravações, destacamos que alguns dos comportamentos apresentados pelos alunos, como os risos, as conversas, os olhares, os gestos 
etc. colaboram para a compreensão dos processos de aprendizagem, como ressaltam Schneuwly e Dolz (2010, p. 134-135):

A comunicação oral não se esgota somente na utilização de meios linguísticos ou prosódicos; vai utilizar também signos de sistemas semióticos não linguísticos, desde que codificados, isto é, convencionalmente reconhecidos como significantes ou sinais de uma atitude. (...) ressaltamos que a comunicação oral se desenvolve não somente no plano verbal e vocal, mas também no plano gestual.

Foi possível observar nos alunos, durante o Debate Regrado, sinais que não são reconhecidos como convencionais para a atividade, entretanto é preciso considerar que estão também aprendendo sobre o sistema semiótico utilizado de diversas maneiras e adequado ao contexto em que se insere o gênero discursivo-textual oral que se está elaborando.

A observação quanto ao comportamento dos alunos, pode nos apontar sobre sérios problemas relacionados ao próprio ambiente escolar, como uma cultura de desorganização e falta de projeto pedagógico em que é comum identificarmos determinados comportamentos dos alunos como "comuns" e até "naturais". Se a escola não consegue ensinar novos modelos e suas características ou vantagens, e mesmo os valores que os comportamentos contêm, os alunos aplicam os modelos que conhecem, e isto pode ser considerado como "grosseria" ou "falta de educação".

Podemos apontar ainda que, de maneira superficial, a fragilidade da própria alfabetização do ponto de vista da decodificação dos símbolos, além dos processos imbricados de compreensão e interpretação no contexto de uma escola e de uma sociedade altamente letrada, pode levar os alunos a vários comportamentos, entre eles aqueles que se apresentam nas transcrições: risos, tom satírico, conversas e outros.

Elucidamos um segundo exemplo do turno de fala, no quadro 13 onde destacamos a análise do indicador "Tema/Assunto/Conteúdo da SD” em que o aluno expõe o seu ponto de vista. 
Quadro 13 - Exemplo II de turnos de falas dos alunos no Debate Regrado da SD "O Brasil vai de quê?"

\begin{tabular}{|c|c|c|}
\hline TURNOS & FALAS TRANSCRITAS & $\begin{array}{c}\text { CRITÉRIOS DE } \\
\text { ANÁLISE } \\
\end{array}$ \\
\hline \multirow{7}{*}{$\mathbf{2}^{\mathbf{o}}$} & Aluno 30 - Aluno 37. & $\begin{array}{c}\text { Elementos estáveis do } \\
\text { gênero }\end{array}$ \\
\hline & $\begin{array}{l}\text { Aluno } 37 \text { - Eu não concordo porque a... Eu prefiro } \\
\text { o multimodal, tipo, aí só que cada transporte ( )vai } \\
\text { com outro, só que o Brasil investe muito em } \\
\text { rodovia. E rodovia é carro. São Paulo, por } \\
\text { exemplo, só tem rodovia, ferrovia é metrô ou trem, } \\
\text { mas também não tem barco (hipótese) ( ). }\end{array}$ & $\begin{array}{c}\text { Tema/Assunto/Conteúdo } \\
\text { da SD }\end{array}$ \\
\hline & Plateia-( ) & \\
\hline & Aluno 37 - Só você que anda de foguete. & \\
\hline & Plateia - Risos & \\
\hline & Plateia - Continua! Continua! Deixa ele falar. & $\begin{array}{c}\text { Elementos estáveis do } \\
\text { gênero }\end{array}$ \\
\hline & $\begin{array}{l}\text { Aluno } 37 \text { - Aí, aí a ferrovia também tem que entrar } \\
\text { carga, caminhão também anda aí na rodovia } \\
\text { caminhão também entra aí. Eu não concordo! Eu } \\
\text { prefiro o transporte multimodal no Brasil. }\end{array}$ & $\begin{array}{c}\text { Tema/Assunto/Conteúdo } \\
\text { da SD }\end{array}$ \\
\hline
\end{tabular}

Fonte: Elaboração Ketlin E.T.W. Fiocco

No Exemplo II do turno de fala é possível observar que mesmo com poucos referenciais dados, o aluno reconhece os problemas do modelo adotado pelo país quando na adoção do transporte rodoviário para construção das principais vias de mobilidade, em função dos interesses das grandes empresas transnacionais na década de 1960, época do open econômico do país, estimulado pelo governo da ditadura militar.

Ainda que os critérios de análise Tema/Assunto/Conteúdo da SD; elementos estáveis do gênero; argumentação e a mediação da aprendizagem se apresentassem indicados para cada um dos turnos de fala os compreendemos como aspectos fortemente imbricados no fluxo e no movimento de uma condição tensa de fala em que o texto oral é produzido na própria ação dos sujeitos. 


\subsection{O necessário entrecruzamento da oralidade, da leitura e da escrita na sequência didática por gênero discursivo oral}

Situada na outra extremidade em relação ao oral espontâneo, nossa proposta de elaboração textual oral, Debate Regrado, envolveu o que identificamos posteriormente como "escrita oralizada" por meio da leitura oral da questão problema da SD.

Em cada um dos turnos de Debate Regrado, observamos que muitos alunos, no momento de participarem oralmente, insistiram no pedido de repetição da questão central da Sequência Didática pelo aluno mediador.

Ao longo das gravações dos turnos de Debate Regrado com as turmas dos $7^{\circ}$ anos de nossa amostra empírica temos trinte e seis (36) repetições da mesma questão. Sem considerar as inúmeras vezes que a mesma questão foi apresentada para as elaborações textuais escritas iniciais e intermediarias, para as atividades propostas em cada um dos módulos da Sequência Didática.

O fato nos chamou a atenção pelo aspecto quantitativo da repetição, pela observação dos efeitos no comportamento quanto à participação dos alunos no Debate Regrado e pela presença das características da oralidade no entrecruzamento com a leitura e a escrita.

Durante o Debate, convivemos com três situações diferentes, a primeira em que os alunos mediadores acataram o pedido de repetição da questão-problema pelos alunos; a segunda em que impedimos a leitura, solicitando que retomassem a questão, uma vez que já tinha sido estudada por várias aulas, e por fim, a terceira situação em que julgamos necessária a leitura, a fim de garantir de alguma forma a participação oral dos alunos.

Diante do fato, considerando que a aplicação da SD iniciou-se no mês de agosto e o Debate ocorreu em novembro, o que mais nos intrigou foi que muitos alunos demonstraram um comportamento em que pareciam estar diante de uma questão-problema que nunca tinham ouvido antes.

Sabendo-se das inúmeras explicações possíveis para o fato, nos apoiamos na observação direta dos comportamentos dos adolescentes das gerações atuais, que ao longo de nossa atuação profissional como docente, tem se mostrado em um ritmo acelerado de mudanças, exigindo da escola e consequentemente dos professores respostas rápidas às atuais demandas.

Os alunos estão expostos, cada vez mais diretamente, a um volume de estímulos e informações que os tem deixado sem critérios para distinguirem acerca do que é relevante ou 
não, sem uma conduta cognitiva planejada, procuram por várias coisas ao mesmo tempo, não conseguem pensar e refletir de maneira sintética ou relacional acerca das diversas informações que se apresentam de maneira frágil e fragmentada.

O desafio está posto diante do comportamento dos adolescentes que Bauman (2012, p.125) assim caracteriza:

A educação assumiu muitas forças no passado e se demonstrou capaz de adaptar-se à mudança das circunstâncias, de definir novos objetivos e elaborar novas estratégias. Mas, permitam-me repetir: a mudança atual não é igual às que se verificaram no passado. Em nenhum momento crucial da história da humanidade os educadores enfrentaram desafio comparável ao divisor de águas que hoje nos é apresentado. A verdade é que nós nunca estivemos antes nessa situação. Ainda é preciso aprender a arte de viver num mundo saturado de informações. E também a arte mais difícil e fascinante de preparar seres humanos para essa vida.

Em outra obra, o mesmo autor pondera sobre os efeitos dos volumes de informação disponíveis aos seres humanos:

(...) quando quantidades crescentes de informação são distribuídas a uma velocidade cada vez maior, torna-se progressivamente mais difícil criar narrativas, ordens ou sequências de desenvolvimento. Os fragmentos ameaçam se tornar hegemônicos. Isso tem consequências para as maneiras como nos relacionamos com o conhecimento, o trabalho e o estilo de vida num sentido amplo. (BAUMAN, 2013, p.36)

Para Feuerstein (2014, p.52) a aprendizagem mediada é essencial para o desenvolvimento tanto biológico quanto sociocultural, particularmente no contexto de informações excessivas em que nossos alunos se encontram, impedindo-os que aprendam a melhor maneira de operarem adequadamente e eficientemente com os fenômenos e situações que se deparam todos os dias.

A necessidade de repetição da leitura oral da questão-problema da SD que se apresentou nos turnos de debate da Sequência Didática aplicada se mostrou necessária como parte do processo de elaboração do pensamento de cada um dos alunos, sendo uma repetição repleta de significado, pois havia o contexto de uma discussão organizada em um gênero discursivo-textual.

No plano empírico de nossa pesquisa compreendemos a repetição como elemento importante e essencial, não como atividade sem sentido e mecânico ou apenas para ocupar o tempo da aula, mas sim para a construção de novas formas de pensamento acerca de um conhecimento, contrariando assim posições pedagógicas que defendem grandes quantidades de conteúdos em um tempo-aula totalmente contrário ao tempo da elaboração do pensamento. 
Ainda que de maneira muito incipiente para muitos alunos, com baixo desempenho verbal oral, a repetição, neste sentido apoiou a organização das representações internas em um encadeamento estrutural, servindo para muitos como um tempo de elaboração, assimilação e organização de informações em um esforço mental de construir novas possibilidades de responder a mesma questão. Não deixando de considerar também os alunos mediadores do próprio debate que também vivenciaram a repetição no contexto em que ocorreu.

Selecionamos os cinco alunos que participaram como mediadores dos turnos de Debate em que organizamos a análise das elaborações textuais escritas, quanto a presença de aspectos da oralidade e de elementos do gênero primário, e a análise da participação no Debate Regrado em que destacamos a quantidade de leituras orais da questão problema da $\mathrm{SD}$, as intervenções e contribuições realizadas durante a fala dos colegas, o ponto de vista, os argumentos e os referenciais utilizados.

Quadro 14 - Entrecruzamento da oralidade, da leitura e da escrita na SD.

\begin{tabular}{|c|c|c|}
\hline ALUNOS & $\begin{array}{l}\text { ANÁLISE DA ELABORAÇÃO } \\
\text { ESCRITA }\end{array}$ & $\begin{array}{l}\text { ANÁLISE DA PARTICIPAÇÃO NO DEBATE } \\
\text { REGRADO }\end{array}$ \\
\hline Aluna 14 & $\begin{array}{l}\text { Apoia-se em elementos estáveis } \\
\text { do gênero desde a primeira } \\
\text { elaboração escrita, no que diz } \\
\text { respeito à ausência de traços da } \\
\text { oralidade no texto escrito. }\end{array}$ & $\begin{array}{l}\text { Leituras da questão-problema: 10. Conseguiu fazer } \\
\text { explicações aos colegas sobre as perguntas realizadas. } \\
\text { Enquanto mediadora do debate assume a } \\
\text { responsabilidade de julgar as arbitrariedades das } \\
\text { regras do debate, por exemplo, quando a professora } \\
\text { participa fazendo perguntas e outra aluna argumenta } \\
\text { dizendo que não vale. (AV-8m50s) Traz para o debate } \\
\text { elementos estudados nas aulas, por exemplo, o roubo } \\
\text { de cargas nas rodovias, a sobrecarga do modal } \\
\text { rodoviário, altos impostos, elevado número de } \\
\text { acidentes, altos preços dos pedágios, e prejuízos para o } \\
\text { meio ambiente (AV4-21m34s) Mais uma vez } \\
\text { questiona o colega utilizando-se de informações do } \\
\text { último texto trabalhado nas aulas "Análise do setor de } \\
\text { transportes" sobre a competitividade nas exportações, } \\
\text { por exemplo. (AV2-7m40s) }\end{array}$ \\
\hline Aluno 24 & $\begin{array}{l}\text { Não há mudanças quanto à } \\
\text { presença de traços da oralidade } \\
\text { nas elaborações textuais. }\end{array}$ & $\begin{array}{l}\text { Leituras da questão-problema: 8. Como mediador } \\
\text { de um dos turnos do debate, apoiou o colega quando } \\
\text { deu um exemplo de sua experiência (AV5-31m51s) } \\
\text { ao andar de trem dizendo que o mesmo parou muitas } \\
\text { vezes durante o trajeto. }\end{array}$ \\
\hline Aluno 30 & $\begin{array}{l}\text { Não há mudanças quanto à } \\
\text { presença de traços da oralidade } \\
\text { nas elaborações textuais, mesmo } \\
\text { participando do debate. }\end{array}$ & Leituras da questão-problema: 6. \\
\hline
\end{tabular}




\begin{tabular}{|c|c|c|}
\hline Aluna 38 & $\begin{array}{l}\text { Há uma variação quanto à } \\
\text { presença da oralidade entre as três } \\
\text { elaborações indicando que em } \\
\text { uma delas houve algum tipo de } \\
\text { mediação da professora e/ou de } \\
\text { algum colega durante o processo } \\
\text { de elaboração textual escrita. }\end{array}$ & $\begin{array}{l}\text { Leitura da questão-problema da SD: 6. Na posição } \\
\text { de mediadora do Debate Regrado elabora uma } \\
\text { pergunta, a partir da fala de um colega, demonstrando } \\
\text { compreensão da ideia, entretanto utiliza-se da vez da } \\
\text { fala do colega alegando que o debatedor queria dizer, } \\
\text { sendo que o debatedor não falou nada. (AV4- } \\
17 \mathrm{~m} 01 \mathrm{~s} \text { ) Como debatedora defende o sistema } \\
\text { ferroviário utilizando o argumento de que é mais } \\
\text { confortável, moderno e rápido. (AV11-6m52s) Segue } \\
\text { argumentando que por ser mais rápido e confortável a } \\
\text { população gostaria de utilizá-lo. Ao ser questionada } \\
\text { sobre como possui essas informações limita-se a dizer } \\
\text { que é porque já andou. (AV11- } 12 \mathrm{~m} 00 \mathrm{~s} \text { ) Disse que } \\
\text { aprendeu coisas que não sabia, ou que não prestou } \\
\text { atenção nas aulas, com os outros colegas. (AV11- } \\
22 \mathrm{~m} 22 \mathrm{~s} \text { ) }\end{array}$ \\
\hline Aluna 43 & $\begin{array}{l}\text { Consolidado desde o início os } \\
\text { elementos estáveis do gênero no } \\
\text { que diz respeito à ausência de } \\
\text { traços da oralidade no texto } \\
\text { escrito. }\end{array}$ & $\begin{array}{l}\text { Leitura da questão-problema da SD: 6. Posiciona-se } \\
\text { a favor de investimentos na malha ferroviária } \\
\text { argumentando que é mais rápida e tem mais espaço. } \\
(\mathrm{AV} 3-4,59 \mathrm{~s}) \text { No turno anterior defendeu investimentos } \\
\text { em rodovias e ferrovias (AV10-7m } 15 \mathrm{~s})\end{array}$ \\
\hline
\end{tabular}

Fonte: Elaboração Ketlin E. T. W. Fiocco

$\mathrm{Na}$ amostra com os alunos mediadores do Debate, é possível observar que apenas um aluno (Aluno 30) não apresentou uma participação mais efetiva, porém realizou seis (6) vezes a leitura oral da questão-problema, que se constituiu como uma importante forma de participação, principalmente para um aluno que no início da tarefa se recusou a participar oralmente.

Na busca de um ensino coerente da oralidade Schneuwly e Dolz (2010, p. 191) afirmam que:

(...) seria didaticamente razoável levar os alunos a construir exposições não para serem lidas, mas que se apoiem bastante em suportes escritos diversificados, anotações, gráficos, citações, etc., assim como em esquemas baseados em palavras-chave, alguns marcadores de estruturação que permitam ao orador lembrar-se explicitamente do estatuto que atribui a essas palavras-chave em seu planejamento. No entanto, algumas passagens particularmente importantes em termos de conteúdo (enunciado de uma tese etc.) ou de estrutura (enunciados-chave como a abertura, a introdução da conclusão etc.) poderiam ser redigidas e lidas.

A "escrita oralizada" pode ser considerada como um primeiro passo para que os alunos tenham experiências de elaborações textuais orais e que possam assim participar das aulas e progressivamente elaborarem outros gêneros orais que se apoiem em maior ou menor escala na modalidade escrita.

Podemos observar que na função de mediadoras do Debate, duas alunas (Aluna 14 e Aluna 38) frente a uma pergunta elaborada por um dos alunos debatedores e que não foi compreendida pelo colega que deveria responder, realizaram explicações, com o objetivo de 
ajudar a compreensão e com o sentido de uma participação coletiva e mais ativa de elaboração discursiva do gênero textual que se aproxima de uma concepção bakhtiniana:

(...) pelos trabalhos de Bakhtin/Voloshinov afasta-se de uma concepção que o colocaria como autônomo, passível de ser compreendido somente por seus elementos linguísticos, por exemplo, ou pelas partes que o integram, para inseri-lo numa perspectiva mais ampla, ligada ao enunciado concreto que o abriga, a discursos que o constituem, a autoria individual ou coletiva, a destinatários próximos, reais ou imaginados, a esfera de produção, circulação e recepção, interação. (BRAIT, 2012, p.10)

A partir da perspectiva da teoria bakhtiniana que Brait (2012) discute o papel central do texto ${ }^{64}$ e do discurso podemos observar que uma aluna (Aluna 14) traz elementos de outros textos, da modalidade escrita para o debate, enquanto que outra aluna ainda (Aluna 38) transita entre informações de outros textos e um argumento da própria experiência, assim também procede o aluno 24, que exemplifica com a própria experiência, sobre o mau funcionamento dos trens, para apoiar a argumentação de um colega.

Podemos observar o modo como os alunos elaboram seus enunciados e os expressam por meio dos gêneros comportando a construção coletiva e individual de pontos de vista e do próprio conhecimento, possibilitando a uma aluna (Aluna 43) a mudança de posicionamento frente a questão problema da SD, o que para Bakhtin (2010, p. 378) este processo está intrínseco ao sujeito da compreensão:

O sujeito da compreensão não pode excluir a possibilidade de mudança e até de renúncia aos seus pontos de vista e posições já prontos. No ato da compreensão desenvolve-se uma luta cujo resultado é a mudança mútua e o enriquecimento.

Durante a atividade de Debate Regrado foi possível observar aspectos, desempenhados pela função de mediador, como a repetição da leitura oralizada da questão problema e a necessidade da atenção à própria dinâmica de elaboração textual na ação, favorecendo conjuntamente para a elaboração de enunciados, o desempenho verbal oral, a organização das representações internas em um encadeamento um pouco mais estruturado, servindo para muitos alunos como um tempo de elaboração, assimilação e organização de informações em um esforço mental de construir novas possibilidades de responder a mesma questão.

\footnotetext{
${ }^{64}$ Cabe esclarecer que segundo QUINTILIANO (1999, p. 87) "Por discurso entende-se aqui uma atividade comunicativa, produtora de sentido, construída por sujeitos sociais nas interações de que participam. O discurso se manifesta linguisticamente por meio de texto, este, por seu turno, pode-se materializar nas formas oral e escrita. E em face dos propósitos deste trabalho, texto é aqui tomado como unidade de análise, por pressupor que é nele e por meio dele que se podem evidenciar e analisar os elementos linguísticos, enunciativos, e os extralinguísticos que compõem as suas condições de produção e recepção. Em suma, teórica e metodologicamente falando, é no texto e por meio dele é que se pode entender como se dá o funcionamento do discurso".
} 


\subsection{Novos conceitos e palavras chaves do Debate Regrado na escrita}

A fotografia da figura 13 apresenta a capa dos registros em flipchart preenchido com outras ilustrações e palavras ao longo da aplicação da SD e exposto na entrada da sala ambiente de Geografia e que ilustramos um dos critérios de nossa análise: Novos conceitos e palavras chaves do Debate Regrado na escrita.

Nesta etapa de nossa pesquisa verificamos quais as palavras e conceitos que transitaram na elaboração das respostas pelos alunos para a questão-problema e nas atividades da Sequência Didática “O Brasil vai de quê?” tanto no Debate Regrado quanto na elaboração textual escrita.

Figura 13 - Flipchart preenchido com outras ilustrações e palavras exposto na entrada da sala ambiente de Geografia.

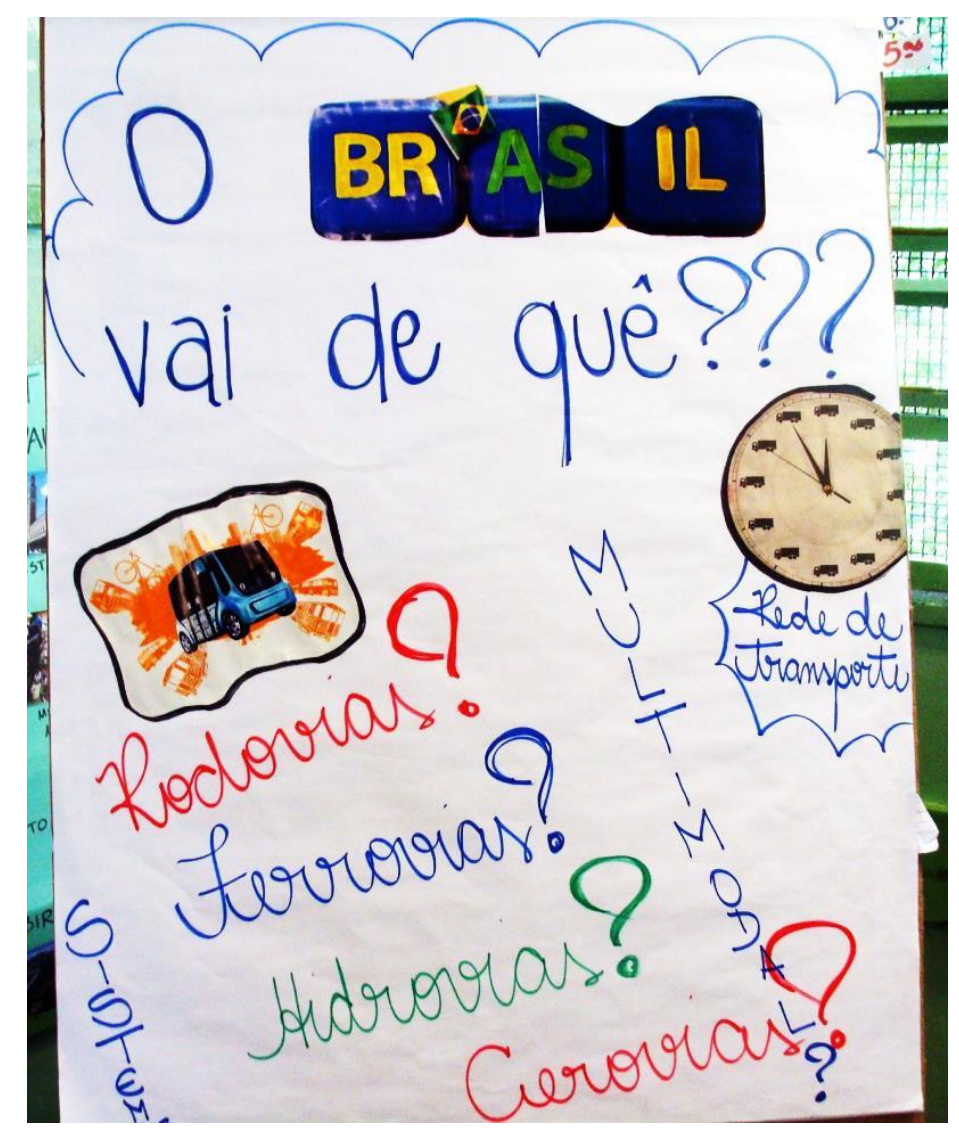

Fonte: Ketlin E. T. W. Fiocco, outubro, 2013.

Retomando o nosso interesse pelas palavras utilizadas pelos alunos no Debate Regrado e posteriormente no texto escrito, segundo Vigotski (2010, p. 149) o domínio dos meios sociais do pensamento (linguagem verbal) se articula ao desenvolvimento do pensamento da criança. 
Quando nos voltamos para o trabalho didático de um Ensino de Geografia por gêneros discursivo-textuais temos como objetivo oportunizar aos nossos alunos o domínio dos meios sociais, comunicacionais e discursivos, que apoiem o desenvolvimento do pensamento, isto é, um pensamento por conceitos.

Trata-se de indicar a existência de dois processos distintos, entretanto imbricados na formação de sujeitos: desenvolvimento e aprendizagem, em especial nos interessa saber acerca do papel construtivo do processo de aprendizagem que segundo Vigotski (2010, p. 304):

\begin{abstract}
A aprendizagem pode produzir mais no desenvolvimento que aquilo que contém em seus resultados imediatos. Aplicada a um ponto no campo do pensamento infantil, ela se modifica e refaz muitos outros pontos. No desenvolvimento ela pode surtir efeitos de longo alcance e não só aqueles de alcance imediato. Consequentemente, a aprendizagem pode ir não só atrás do desenvolvimento, não só passo a passo com ele, mas pode superá-lo, projetando-o para a frente e suscitando nele novas formações. Isto tem uma importância e um valor infinitos.
\end{abstract}

A formulação do psicólogo russo sobre a importância do processo de aprendizagem para o desenvolvimento da criança e do adolescente de uma maneira geral, nos impulsionou ainda mais a desafiar nossos alunos a pensarem acerca de uma problemática que, dificilmente em outra situação do cotidiano seriam levados a pensar, de modo que ao utilizarem novas palavras foram desafiados a elaborarem novos caminhos cognitivos, novas formas de pensar, que somente o cotidiano não os levaria por si.

No cotidiano, crianças e adolescentes elaboram conceitos que possuem ligação com situações mais concretas, os quais Vigotski (2010, p.263) denomina de conceitos espontâneos, entretanto, ao serem desafiados a pensar por problemas que exijam operar com ideias, conteúdos, temas e assuntos mais abstratos, como aqueles próprios da Ciência, desenvolvem novas formas de pensar, mais generalizadoras, próprias de um pensamento que é capaz de elaborar conceitos científicos.

Entre a distinção dos processos de elaboração dos conceitos espontâneos e dos conceitos científicos limitemo-nos a ressaltar o que Vigotski (2010, p.263) destaca sobre a importância da aprendizagem para o desenvolvimento de um pensamento de tipo mais complexo:

A relação dos conceitos científicos com a experiência pessoal da criança é diferente da relação dos conceitos espontâneos. Eles surgem e se constituem no processo de aprendizagem escolar, por via inteiramente diferente que no processo de experiência pessoal da criança. As motivações internas que levam a criança a formar conceitos científicos, também são distintas daquelas que levam o pensamento infantil à formação de conceitos 
espontâneos. Outras tarefas surgem diante do pensamento da criança no processo de assimilação dos conceitos na escola, mesmo quando o pensamento está entregue a si mesmo. (Grifo nosso)

Cabe destacar do excerto a importância que Vigotski atribui aos processos de aprendizagem, que ocorrem no interior das escolas para o desenvolvimento dos conceitos científicos pelos alunos sejam eles potencializados pela mediação ou aqueles que ocorrem pela exposição direta do sujeito ao objeto.

O objeto central desta análise são as palavras e os conceitos utilizados pelos alunos, ou seja, "as palavras trazem vozes" (AMORIM, 2004, p.251) dos sujeitos que estão em processo de elaboração de conceitos, como explica Vigotski (2010, p. 265):

Tudo consiste em entender que a formação dos conceitos científicos, na mesma medida que os espontâneos, não termina, mas apenas começa no momento em que a criança assimila pela primeira vez um significado ou termo novo para ela, que é veículo de conceito científico. Essa é a lei geral do desenvolvimento do significado das palavras, à qual estão igualmente subordinados em seu desenvolvimento tanto os conceitos científicos quanto os espontâneos.

Quando nos voltamos para as palavras utilizadas pelos alunos no Debate Regrado e no texto escrito, compreendemos como afirma Vigotski, que o processo de elaboração de conceitos científicos apenas se iniciou e por isso consideramos que a amostra analisada se constitui como parte de um processo bem mais amplo e complexo de aprendizagem e desenvolvimento dos sujeitos envolvidos.

Entre outros aspectos do recorte que apresentamos do processo de aprendizagem e desenvolvimento destacamos a representação da ideia de mundo que os alunos constroem ao longo da escolarização, apoiados pelas imagens, pela fala e pelos conceitos como explica Moreira (2013, p. 107) :

A representação é o mundo construído na dialética da imagem e da fala. Vimos que a imagem surge no campo da senso-percepção, e a fala surge no campo da tradução intelectiva dessa imagem, e que ambas estão inscritas no conceito. A representação é o produto da transcodificação que se estabelece entre a imagem e fala dentro do conceito, na qual a imagem se exprime pela fala e a fala codifica e dá voz à imagem. Assim, na representação, é pela fala e pela imagem que o mundo se nos apresenta. E é por meio delas que se faz presente. De modo que o mundo é a imagem e a fala com que o representamos ao fazermos intervir o sentido da significação no conceito.

Ainda que discordamos de Moreira quanto à explicação de que a representação de mundo seja elaborada na dialética da imagem e da fala, uma vez que as contradições superadas em sínteses nem sempre são capazes de responder à complexidade dos 
fenômenos ${ }^{65}$, ela nos apoia na compreensão dos elementos e operações mentais envolvidos na construção da representação de mundo: fala, percepção, análise, codificação, e o próprio processo de elaboração de conceitos.

A aproximação da explicação que Moreira apresenta, do processo de elaboração da ideia de mundo aproxima ainda mais a Geografia, enquanto disciplina do currículo escolar, das discussões que propomos acerca da importância da oralidade, por meio da força temática que a própria ciência possui, do ser humano e sua espacialidade, além da necessidade em que Morin (1999, p.93) afirma "os humanos precisam de uma visão de mundo".

Para Moreira (2013, p.107) a visão de mundo "corresponde ao modo como estruturamos nossa relação com as coisas que nos rodeiam a partir da ideia que formamos delas". Do modo como os processos de aprendizagem e de desenvolvimento articulam e integram fala, percepção, análise, codificação, e o próprio processo de elaboração de conceitos é que se elaboram a visão de mundo dos sujeitos.

Uma das fontes de erros e ilusões do conhecimento conferimos à ausência de articulação entre os elementos e operações mentais que não se efetivam no processo de construção da visão de mundo.

Morin (2011, p. 19-20) apresentou o que denominamos desarticulações do processo de elaboração da visão de mundo e que levam a erros e ilusões e que podem ser combatidas:

Todas as percepções são, ao mesmo tempo, traduções e reconstruções cerebrais com base em estímulos ou sinais captados e codificados pelos sentidos. Daí resultam, sabemos bem, os inúmeros erros de percepção, que nos vêm de nosso sentido mais confiável, o da visão. (...)

O conhecimento, sob forma de palavra, de ideia, de teoria, é o fruto de uma tradução/reconstrução por meio da linguagem e do pensamento e, por conseguinte, está sujeito ao erro. (...)

Este conhecimento, ao mesmo tempo tradução e reconstrução, comporta a interpretação, o que introduz o risco do erro na subjetividade do conhecedor, de sua visão do mundo e de seus princípios de conhecimento.

Nos excertos que citamos de Morin (2011) o autor apresenta e explica como que três aspectos e operações mentais que compõem nossa construção de mundo, a percepção, a

\footnotetext{
${ }^{65}$ Encontramos em Morin (1997, p.194-195) na exposição que faz sobre o processo de elaboração de suas ideias no livro Meus demônios o trecho em que explica sobre a adoção do conceito de dialogia em substituição ao de dialética: "A crítica da dialética intemperante, que "superava" sempre as contradições em "sínteses", me levava a reconhecer o caráter irredutível das contradições fundamentais do conhecimento dos mundos físico, biológico e humano. Encontra assim, a racionalidade deve comportar não a eliminação ou a "superação" das contradições, mas o reconhecimento de sua irredutibilidade. Desde então, sem que eu pudesse ainda denominá-la, a dialógica (entre instâncias ao mesmo tempo antagônicas e complementares) começava a tomar lugar da dialética".
} 
codificação e decodificação, e a interpretação, desarticulados levam ao erro, ilusões e cegueiras do conhecimento.

O mesmo autor destaca, ainda que com ressalvas, a importância da ciência como um poderoso meio de detecção de erros e de luta contra as ilusões e cegueiras do conhecimento. A Geografia, como ciência humana presente no currículo escolar pode apoiar os alunos na detecção de erros, ilusões e cegueiras do conhecimento, pela via do desenvolvimento de pensamentos por conceitos, ou seja, pensamentos menos dependentes da materialidade física e mais generalizantes por meio da colaboração criativa entre os elementos que estruturam as relações entre as coisas e consequentemente com uma visão de mundo mais complexa acerca dos fenômenos e da realidade que vivemos.

Em caráter experimental, por meio das transcrições dos turnos de fala e, conscientes das limitações que a modalidade escrita impõe à modalidade oral, escolhemos os alunos da turma do $7^{\circ}$ ano $\mathrm{B}$, pois esta foi a única turma em que tivemos a oportunidade de realizar três turnos de Debate Regrado, para verificarmos as palavras que os alunos mais utilizaram ao longo da atividade, compará-las com aquelas que foram utilizadas nos textos escritos finais, bem como aquelas que estavam presentes em nosso planejamento da $\mathrm{SD}$, a fim de apreendermos da fala dos alunos parte do processo de elaboração dos conceitos científicos.

Como forma de materializar o gênero discursivo-textual oral Debate Regrado, realizamos as transcrições dos turnos de falas, ou seja, passamos o texto da modalidade oral para a modalidade escrita, o que reflete apenas parte da complexidade dos elementos que na prática compõe a oralidade, sobretudo dos meios não linguísticos, como a qualidade da voz, a ocupação e disposição dos lugares, os gestos etc., como afirmam Schneuwly e Dolz (2010, p. 135):

Uma característica da produção oral é que o oral espontâneo aparece, na leitura de transcrições, completamente desordenado. No entanto, todas essas manifestações de desordem podem ser analisadas na ótica de um funcionamento adequado da interação oral.

Para o processo de quantificação e identificação das palavras mais utilizadas pelos alunos durante os turnos de Debate Regrado, nos dispomos da ferramenta de criação de nuvens de palavras, disponível na web por meio do aplicativo tagcrowd ${ }^{66}$ em que excluímos dos textos transcritos dos turnos de DR, bem como das elaborações finais dos alunos, os artigos, os nomes dos alunos e as expressões próprias da oralidade, como por exemplo, "tipo",

\footnotetext{
${ }^{66}$ Disponível em: http://tagcrowd.com/ acesso em 01 out. 2016.
} 
“aí" etc., a fim de obtermos as palavras-chaves da temática da Rede de Transportes e posterior categorização.

As duas primeiras categorizações dizem respeito aos dois principais conceitos que estiveram presentes ao longo das atividades da SD: meios de transporte e rede de transportes, organizadas e apresentadas nos gráficos 10 e 11.

Como já expusemos na análise anterior dos traços da oralidade nos textos escritos dos alunos, o conceito de meios de transporte não foi previsto no planejamento de nossa SD, uma vez que nosso foco era a Rede de Transportes.

Porém ao verificarmos como os alunos estavam pensando o problema da SD por meio das palavras utilizadas referentes aos meios de transportes, como carro, metrô, ônibus e trem tivemos a oportunidade de mediar o conceito da Rede de Transportes com o qual tiveram que se utilizar de outras palavras a fim de apoiar a nova forma de pensar.

Gráfico 10 - Palavras-chave: Meios de Transporte - $7^{\circ}$ Ano B

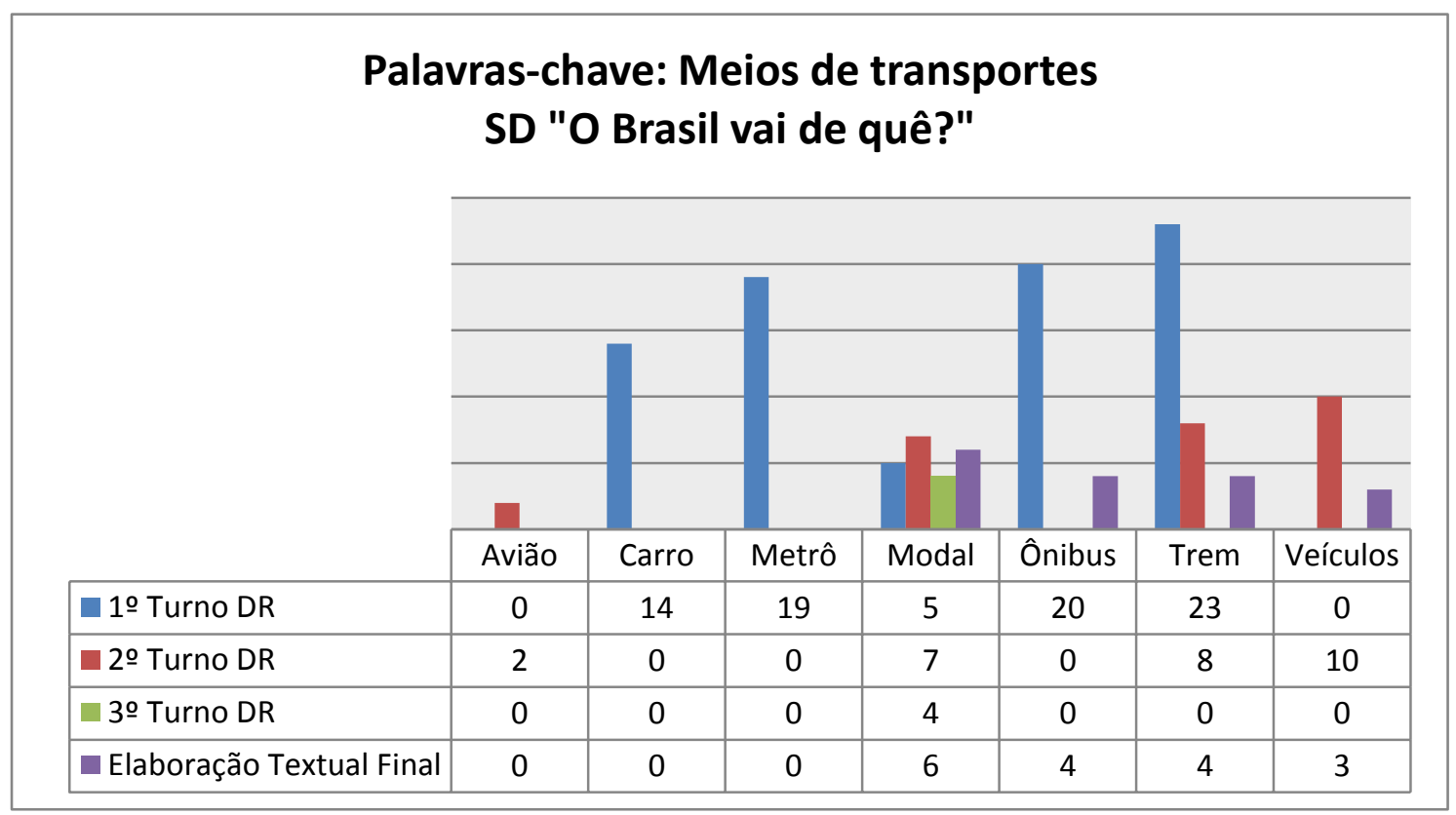

Fonte: Elaboração Ketlin E. T. W. Fiocco 
Gráfico 11 - Palavras-chave: Rede de Transportes - $7^{\circ}$ Ano B

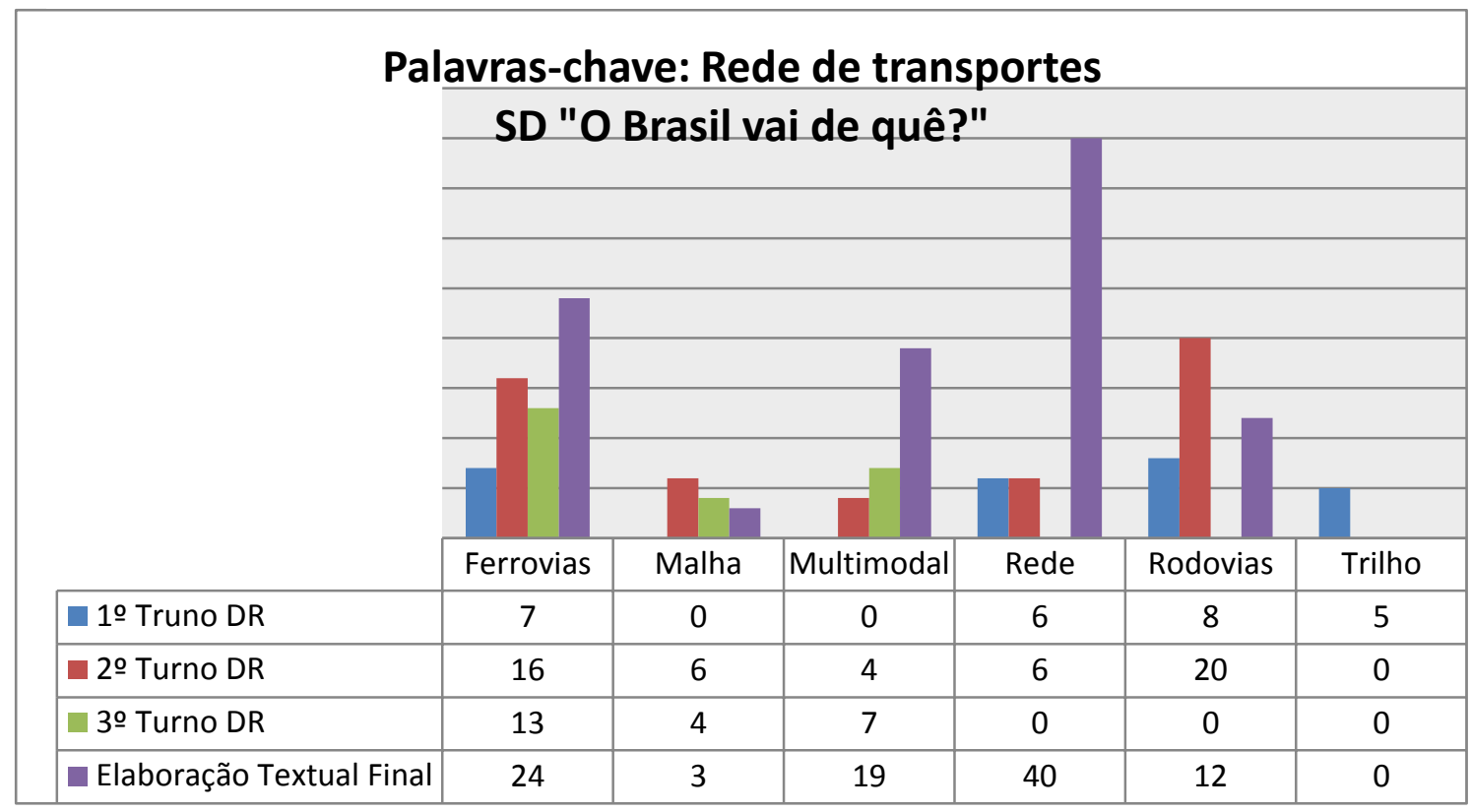

Fonte: Elaboração Ketlin E. T. W. Fiocco

Na categoria Rede de Transportes é possível observar que as ferrovias e rodovias se destacaram durante os turnos de DR e a utilização das palavras que apoiam este conceito foi amplamente empregado pelos alunos nas elaborações textuais finais. Destacamos que listamos apenas as palavras que apareceram mais de três vezes em um dos turnos de DR e ou na elaboração escrita final, e apesar de não terem sido contemplados, as hidrovias e aerovias também foram utilizadas duas vezes nos textos escritos.

Após o primeiro turno de DR verificamos por meio das palavras expostas pelos alunos como estavam organizando o pensamento em torno do conceito de meios de transportes, resolvemos então, expor uma lista de palavras que tinha como objetivo apoiar os alunos durante suas participações no DR. (figura 14)

Esta nossa ação sugere dois aspectos, sendo o primeiro a nossa preocupação em apoiar os alunos no processo de elaboração de conceitos científicos por meio das palavras e o segundo aspecto se aproxima do que Vigotski (2010, p. 247) afirma, "Mas a prática também mostra a cada passo o equívoco dessa concepção. Não menos que a investigação teórica, a experiência pedagógica nos ensina que o ensino direto de conceitos sempre se mostra impossível e pedagogicamente estéril".

Como exemplo, podemos destacar a palavra "tecnologia" que indicamos em nossa lista, porém não foi utilizada pelos alunos, pois o contexto em que poderia ser aplicada a palavra não foi desenvolvida ao longo da SD. 
Figura 14 - Lista de palavras apresentadas aos alunos durantes os turnos de DR da SD "O Brasil vai de quê?"

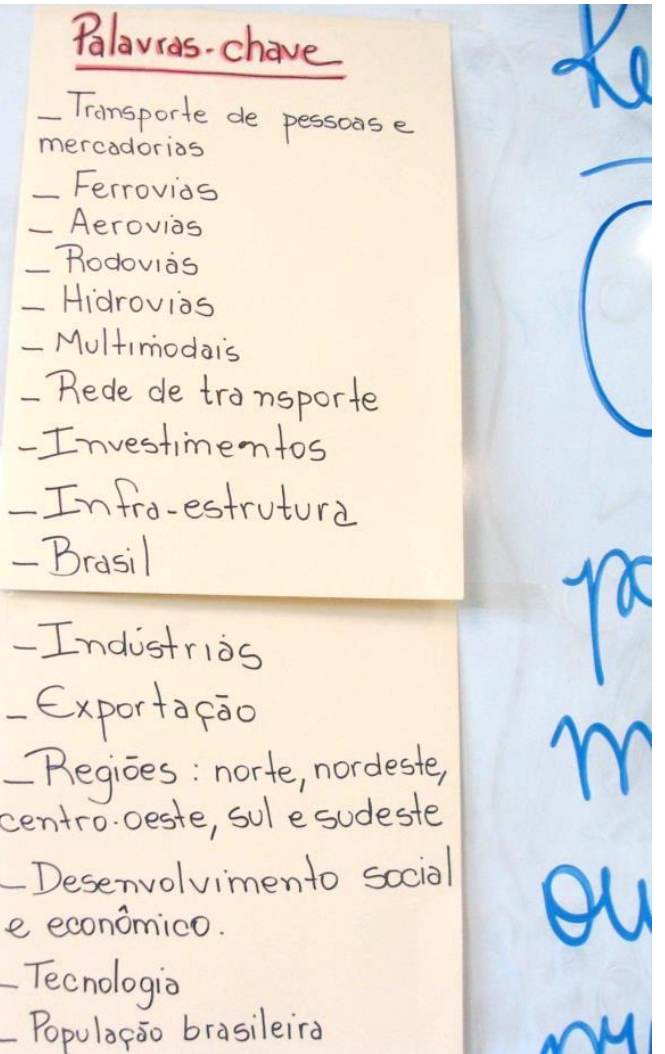

Fonte: Ketlin E. T. W. Fiocco, novembro, 2013.

Outra categoria de análise das palavras utilizadas pelos alunos está relacionada a utilização da Rede de Transportes que apresentamos no gráfico 12.

Gráfico 12 - Palavras-chave: Utilizações da Rede de Transportes - $7^{\circ}$ Ano B.

\begin{tabular}{|c|c|c|c|c|c|c|c|}
\hline \multicolumn{8}{|c|}{$\begin{array}{l}\text { Utilizações da Rede de Transportes } \\
\text { SD "O Brasil vai de quê?" }\end{array}$} \\
\hline & \multicolumn{7}{|c|}{$\longrightarrow$} \\
\hline & \multicolumn{3}{|c|}{ 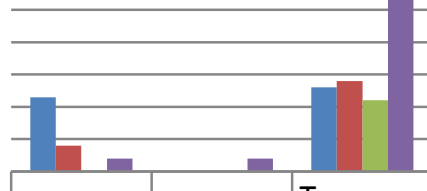 } & - & & & \\
\hline & Pessoas & Produtos & $\begin{array}{c}\text { Transpor } \\
\text { te }\end{array}$ & Usar & Visitar & Cargas & $\begin{array}{c}\text { Exportaç } \\
\text { ões }\end{array}$ \\
\hline 10 Turno DR & 23 & 0 & 26 & 0 & 0 & 0 & 0 \\
\hline 2o Turno DR & 8 & 0 & 28 & 2 & 4 & 0 & 0 \\
\hline 3o Turno DR & 0 & 0 & 22 & 4 & 0 & 0 & 0 \\
\hline Elaboração Textual Final & 4 & 4 & 80 & 0 & 0 & 10 & 5 \\
\hline
\end{tabular}

Fonte: Elaboração Ketlin E. T. W. Fiocco 
Podemos verificar no gráfico das palavras "Utilizações da Rede de Transportes" (gráfico 12) o amplo emprego pelos alunos da expressão "transporte de pessoas" nos indicando a necessidade de levá-los a pensar também sobre o transporte de mercadorias, sendo interessante destacar que os alunos, ao longo dos turnos, deixam de empregar a ideia de "transporte de pessoas", entretanto não empregam a palavra "mercadorias" e posteriormente no texto escrito aplicam as palavras "cargas" e "exportações".

Os alunos, ao deixarem de se apoiar em uma palavra para exprimirem suas ideias, sinalizam para a necessidade de uma nova palavra, porém sua utilização não se faz de maneira automática, mas entre elos complexos que podem ser assim explicados:

O caminho entre o primeiro momento em que a criança trava conhecimento como o novo conceito e o momento em que a palavra e o conceito se tornam propriedade da criança é um complexo processo psicológico interior, que envolve a compreensão da nova palavra que se gradualmente a partir de uma noção vaga, a sua aplicação propriamente dita pela criança e sua efetiva assimilação apenas como elo conclusivo. (VIGOTSKI, 2010, p. 250) (Grifo nosso)

Os grifos que fizemos no excerto de Vigotski nos apoiam na compreensão do processo de elaboração de conceitos científicos, ou quando as palavras se tornam propriedade da criança e do adolescente, que se inicia com uma noção vaga e que envolve a compreensão, posteriormente sua aplicação e se efetiva na sua assimilação.

Os alunos de nossa pesquisa, ao utilizarem a palavra "pessoa", sugerem uma assimilação que se aproxima mais do conceito de "meios de transporte" e ao serem desafiados para pensarem, além do conceito que já possuíam, deixam de utilizar a palavra conhecida, pois ela já não é mais capaz de condizer com sua nova aplicação conceitual, e apesar de sugerirmos a palavra "mercadorias" ela não é empregada imediatamente e acabam escrevendo em seus textos "cargas" e "produtos".

Categorizamos as palavras em outros dois grupos que se articulam, sendo o primeiro relacionado aos problemas e características da RT (gráfico 13) e o segundo grupo relacionado às possíveis soluções para os problemas e suas consequências de um modo geral (gráfico 14). 
Gráfico 13 - Palavras-chave: Características e problemas da Rede de Transportes - $7^{\circ}$ Ano B.

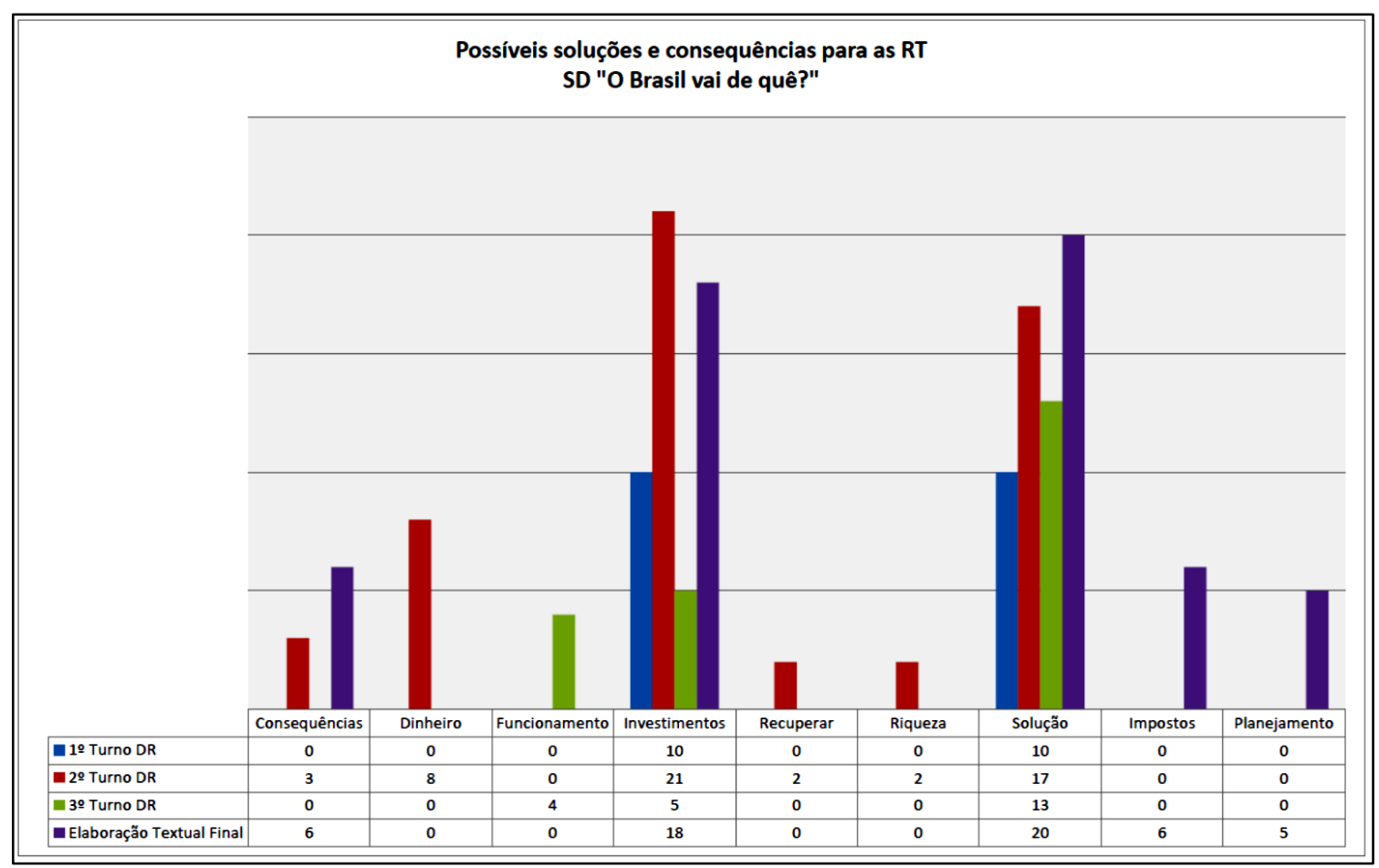

Fonte: Elaboração Ketlin E. T. W. Fiocco.

Gráfico 14 - Palavras-chave: Possíveis soluções e consequências para as Rede de Transportes $7^{\circ}$ Ano B.

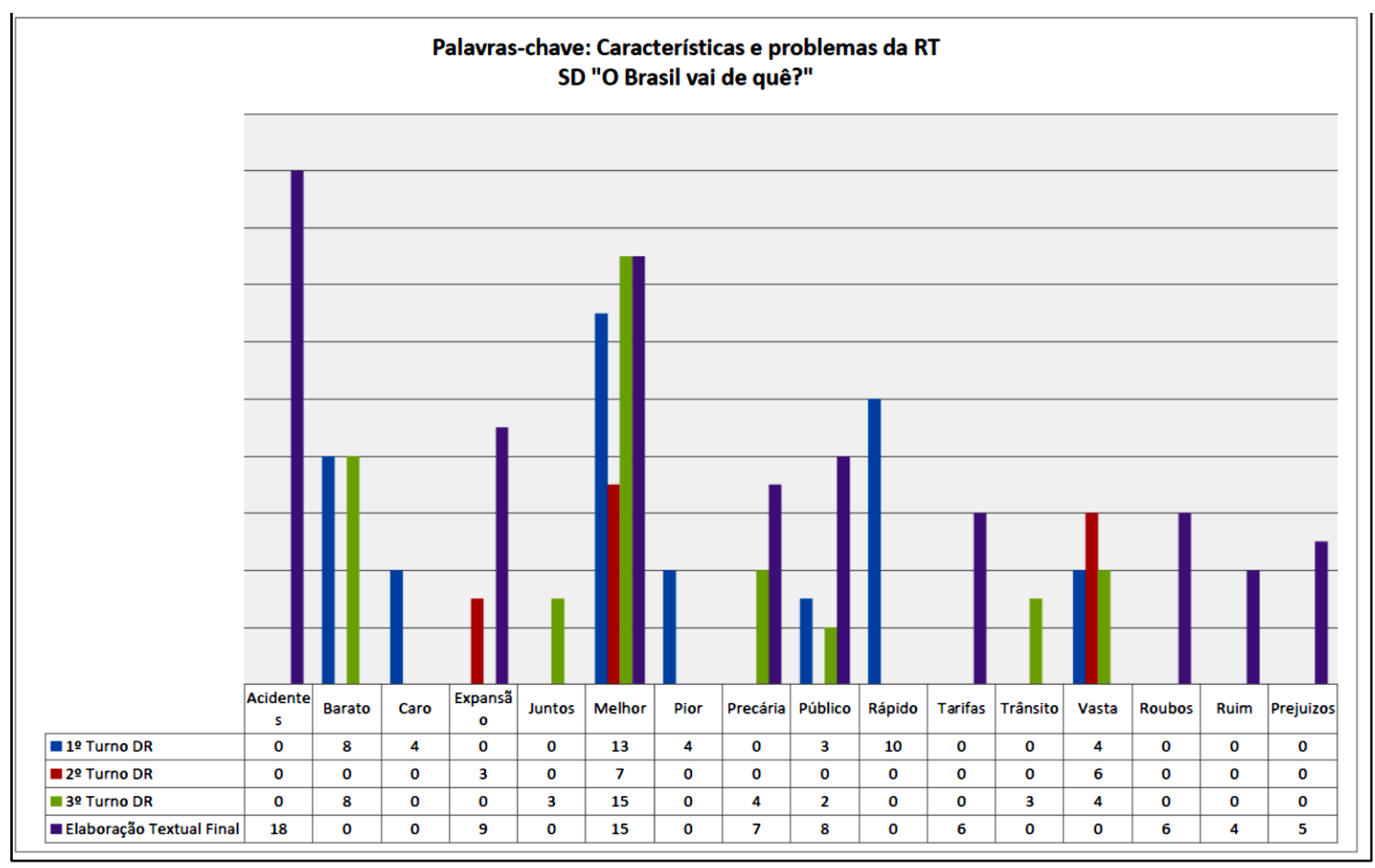

Fonte: Elaboração Ketlin E. T. W. Fiocco 
Nas duas categorias, tanto no grupo das palavras relacionadas aos problemas, quanto ao grupo das palavras relacionadas as situações da Rede de transportes no Brasil, por um lado é possível verificar que os alunos apresentaram menos recursos verbais ao longo dos turnos de DR. Por outro lado, é possível verificar nas duas categorias que há uma diversificação das palavras utilizadas pelos alunos no texto escrito.

A diversificação das palavras empregadas pelos alunos em seus textos que foram escritos depois da realização do Debate Regrado indicam, de nossa parte, uma mediação intencional e objetiva quanto à ampliação do vocabulário dos alunos, ou seja, a observação do baixo desempenho verbal oral de nossos alunos nos ofereceu elementos para que pudéssemos mediar o uso de novas palavras pelos alunos, constituindo o que Vigotski (2010, p.251) afirma:

(...) o ensino consciente de novos conceitos e formas da palavra ao aluno não só é possível como pode ser fonte de um desenvolvimento superior dos conceitos propriamente ditos e já constituídos na criança, que é possível o trabalho direto com o conceito no processo de ensino escolar (...) este trabalho não é o fim, mas o início do desenvolvimento do conceito científico, e não só não exclui os processos propriamente ditos de desenvolvimento como lhes dá uma nova orientação e coloca os processos de aprendizagem e desenvolvimento em novas relações maximamente favoráveis do ponto de vista dos objetivos finais da escola.

Ao contrário de nossa ação anterior de exposição de uma lista de palavras para que os alunos utilizassem ao longo dos turnos de DR que se mostrou estéril, o ensino consciente que Vigotski se referiu ocorreu ao mediarmos os alunos durante a elaboração do texto escrito, em que tinham também outras listas de palavras, porém elaboradas coletivamente com a turma e que foram retiradas sobretudo da dissertação "Análise do setor de transportes" de Sabrina Erhart e Eduardo Mauch Palmeira ${ }^{67}$ apoiando assim um contexto para os processos de aprendizagem e de desenvolvimento.

\subsection{As capacidades de linguagem dos alunos e o Debate Regrado}

No Capítulo 1 de nossa dissertação apresentamos no quadro 3 a proposta de Schneuwly e Dolz (2000, p.51-52) para o agrupamento dos gêneros textuais de acordo com as

67 ERHART, S.; PALMEIRA E. M., Análise do Setor de Transportes in: Observatorio de la Economía Latinoamericana, Número 71, 2006. Disponível em:

http://www.eumed.net/cursecon/ecolat/br/06/semp.htm. Acesso em 06 mai. 2016. 
capacidades de linguagens que podem ser desenvolvidas ao longo da escolarização, em um plano de progressão de ensino.

A argumentação é uma das capacidades de linguagem que, desde o início de nosso trabalho didático com gêneros textuais, esteve presente nos planejamentos, com a intenção inicial de oportunizar aos alunos atividades em que formulassem pontos de vista e que fossem capazes de defendê-los nas modalidades oral e escrita.

Associamos o desenvolvimento da capacidade de linguagem dos alunos em argumentação com as pesquisas de Driver, Newton \& Osborne (2000, p. 288) na área de argumentação científica em que criticamente afirmam que:

Como a prática da argumentação foi desconsiderada também tem falhado a capacitação dos alunos em analisar criticamente as afirmações científicas que são geradas no cotidiano de suas vidas.

(...) A Ciência na escola é comumente retratada a partir de uma "perspectiva positivista" como um assunto em que há claramente "respostas certas" e onde os dados levam sem discussões a conclusões acordadas. ${ }^{68}$ (tradução nossa)

Neste item nos interessou verificar a importância do gênero textual oral Debate Regrado com foco no desenvolvimento da capacidade de argumentação contrariando a perspectiva de um ensino de Ciência com "respostas certas", mas sim para o favorecimento de uma tomada de posição clara e precisa acerca do problema da SD demonstrada nos textos escritos pelos alunos.

Durante o Debate Regrado observou-se em muitos momentos apenas uma exposição de pontos de vista acerca do problema da SD como elucidado no quadro 15.

Quadro 15 - Exemplo III de turnos de falas dos alunos no Debate Regrado da SD "O Brasil vai de quê?"

\begin{tabular}{|l|l|l|}
\hline \multicolumn{1}{|c|}{ TURNOS } & \multicolumn{1}{|c|}{ FALAS TRANSCRITAS } & \multicolumn{1}{c|}{$\begin{array}{c}\text { CRITÉRIOS DE } \\
\text { ANÁLISE }\end{array}$} \\
\hline \multirow{4}{*}{$\begin{array}{l}\mathbf{2}^{\mathbf{0}} \text { Turno }-\mathbf{6}^{\mathbf{a}} \\
\text { SÉRIE } / \mathbf{7}^{\mathbf{0}} \text { ANO } \\
\text { B }\end{array}$} & $\begin{array}{l}\text { Aluno 24 - Éééé } \ldots \text { Vamos começar pela } \\
\text { Aluna 26 porque é a primeira }\end{array}$ & $\begin{array}{l}\text { Elementos estáveis do } \\
\text { gênero }\end{array}$ \\
\cline { 2 - 3 } & $\begin{array}{l}\text { Aluna 26: participante do turno - (pega o } \\
\text { microfone e faz gesto com a mão } \\
\text { perguntando o que tem que falar) }\end{array}$ & $\begin{array}{l}\text { Elementos estáveis do } \\
\text { gênero }\end{array}$ \\
\cline { 2 - 3 } & Aluno 24 -... Da apresentação. & $\begin{array}{l}\text { Elementos estáveis do } \\
\text { gênero }\end{array}$ \\
\hline
\end{tabular}

${ }^{68}$ No original: "Such a disregard for the practice of argument has also failed to empower students with the ability to critically examine the scientific claims generated by the plethora of socioscientific issues that confront them in their everyday lives (...).Science in schools is commonly portrayed from a "positivist perspective" as a subject in which there are clear "right answers" and where data lead uncontroversially to agreed conclusions". (DRIVER, NEWTON \& OSBORNE, 2000, p. 288) 


\begin{tabular}{|l|l|l|}
\hline & $\begin{array}{l}\text { Professora - Faz a pergunta da Sequência } \\
\text { Didática. }\end{array}$ & $\begin{array}{l}\text { Tema/Assunto/Conteúdo } \\
\text { da SD }\end{array}$ \\
\cline { 2 - 3 } $\begin{array}{l}\text { Aluno 24 - A exemplo de muitos países } \\
\text { europeus com vasta malha ferroviária é } \\
\text { comum ouvir que a solução para os } \\
\text { problemas da rede de transportes no Brasil } \\
\text { são investimentos neste modal. Seria esta a } \\
\text { solução para os problemas de transporte no } \\
\text { Brasil? }\end{array}$ & $\begin{array}{l}\text { Tema/Assunto/Conteúdo } \\
\text { da SD }\end{array}$ \\
\cline { 2 - 3 } Aluna 26 - Eu penso que sim. & Argumentação \\
\cline { 2 - 3 } $\begin{array}{l}\text { Plateia - Explica aí. } \\
\text { Plateia - Só isso? }\end{array}$ & Argumentação \\
\cline { 2 - 3 } $\begin{array}{l}\text { Aluna 26 - É. (pausa) Eu penso que sim... } \\
\text { Aluna 26 - Eu penso que sim porque } \\
\text { enquanto que na Europa tá bem mais } \\
\text { avançado que a gente, tá mais } \\
\text { desenvolvido, né? }\end{array}$ & Argumentação \\
\hline
\end{tabular}

Fonte: Elaboração Ketlin E. T. W. Fiocco.

No exemplo selecionado, a proposta do turno de DR iniciou-se com a apresentação do ponto de vista de cada aluno acerca do problema da SD, foi possível verificar a fragilidade dos argumentos apresentados pela aluna, nos indicando o quanto é necessário desenvolver espaços de aprendizado da argumentação associados às práticas discursivas cada vez mais intensas durante as aulas.

Na sequência do mesmo turno de DR há indícios de que os alunos passam a considerar os pontos de vistas e argumentos dos colegas em seus planos de exposição oral, como podemos observar no exemplo do quadro 16.

Quadro 16 - Exemplo IV de turnos de falas dos alunos no Debate Regrado da SD "O Brasil vai de quê?"

\begin{tabular}{|c|c|c|}
\hline TURNOS & FALAS TRANSCRITAS & $\begin{array}{c}\text { CRITÉRIOS DE } \\
\text { ANÁLISE }\end{array}$ \\
\hline \multirow{3}{*}{$\begin{array}{l}2^{\circ} \text { Turno- } 6^{\mathrm{a}} \\
\text { SÉRIE } / 7^{\circ} \text { ANO } \\
\text { B }\end{array}$} & Aluno 30 - Quer que eu leia de novo? & $\begin{array}{l}\text { Tema/Assunto/Conteúdo } \\
\text { da SD }\end{array}$ \\
\hline & Aluno 36 - Claro! (pausa) Lê, lê devagar. & $\begin{array}{l}\text { Tema/Assunto/Conteúdo } \\
\text { da SD }\end{array}$ \\
\hline & $\begin{array}{l}\text { Aluno } 30 \text { - A exemplo de muitos países } \\
\text { europeus com vasta malha ferroviária é } \\
\text { comum ouvir que a solução para os } \\
\text { problemas da rede de transportes no Brasil } \\
\text { são investimentos neste modal. Seria esta a } \\
\text { solução para os problemas de transporte no }\end{array}$ & $\begin{array}{l}\text { Tema/Assunto/Conteúdo } \\
\text { da SD }\end{array}$ \\
\hline
\end{tabular}




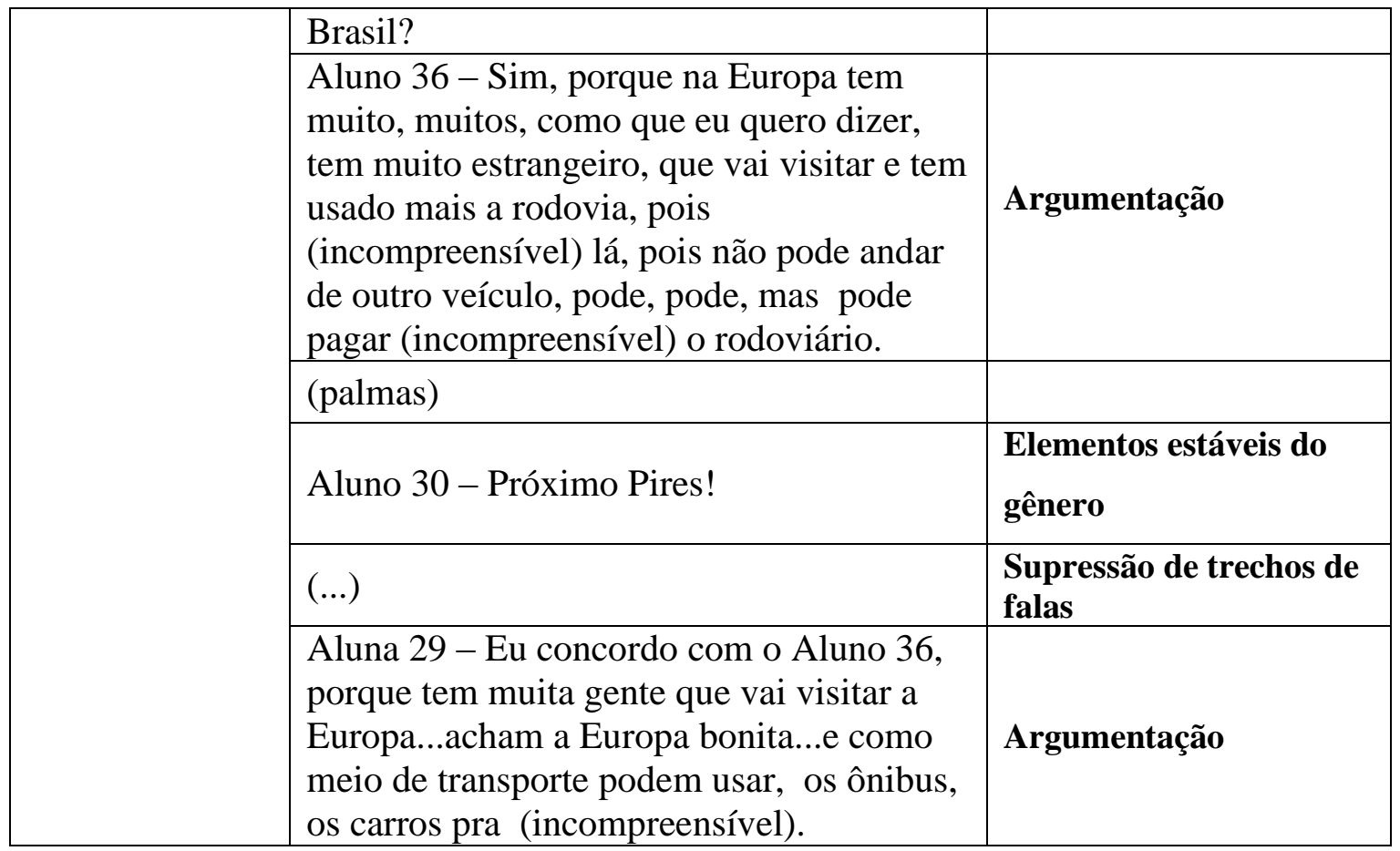

Fonte: Elaboração Ketlin E. T. W. Fiocco.

No exemplo IV do turno de DR, ainda que de maneira incipiente é possível verificar um movimento no sentido da dialogia e da construção coletiva do conhecimento científico, em que um aluno expõe seu ponto de vista utilizando-se de um argumento de exemplo, e outro aluno consegue considerar a fala anterior apropriando-a para seu próprio argumento. De acordo com Driver at al. (2000, p. 297) práticas discursivas podem favorecer aos alunos insights e a construção do conhecimento científico por meio dos seguintes aspectos do que denominam de teoria da argumentação para uma educação científica:

- Apresentação de argumentos coerentes;

- Avaliação de outros argumentos (especialmente os noticiados pela mídia);

- Conhecimento da base do conhecimento necessário para que sejam confrontados.

É possível identificar nos alunos do exemplo IV do turno de DR um tipo de pensamento por complexos que se utiliza de palavras e até conceitos acerca da Rede de Transportes do continente europeu, que foi pesquisado, apresentado e discutido em aulas, porém de maneira equivocada na base do conhecimento requerido para a argumentação científica.

Para Vigotski o pensamento por complexos "lança os primeiros fundamentos de combinação de impressões dispersas, dá os primeiros passos no sentido da generalização dos elementos dispersos da experiência" (VIGOTSKI, 2010, p.220), neste sentido os fragmentos 
de informações que apoiaram nossos alunos constituem-se como parte importante do processo de generalizações, que pudemos verificar posteriormente em seus textos escritos quando passam a se posicionar defendendo claramente um dos sistemas de transporte ou a articulação entre eles.

De nossa amostra de 53 alunos verificamos que 25 alunos, ou seja, 47\%, após participarem de algum dos turnos de DR passam a adotar claramente um ponto de vista, ou seja, de acordo com a teoria da argumentação na educação científica de Driver at al. (2000) os alunos de alguma maneira avaliaram outros argumentos, que foram expostos oralmente durante o debate e passam a expor posições mais claras e precisas.

Quadro 17 - Importância do Debate Regrado para o desenvolvimento das capacidades de linguagem dos alunos.

\begin{tabular}{|l|l|c|c|}
\hline $\begin{array}{c}\text { Análise da importância do } \\
\text { Debate Regrado para a } \\
\text { elaboração do texto escrito }\end{array}$ & \multicolumn{1}{|c|}{ Alunos } & Quantidade & Proporção \\
\hline $\begin{array}{l}\text { Aluno 1, Aluna 2, Aluno 5, } \\
\text { Aluno 11, Aluno 12, Aluna } \\
\text { Passam a se posicionar } \\
\text { defendendo claramente um } \\
\text { dos sistemas de transporte } \\
\text { ou a articulação entre eles } \\
\text { no texto escrito }\end{array}$ & $\begin{array}{l}\text { Aluno 24, Aluno 25, Aluna } \\
\text { 26, Aluno 27, Aluna 29, } \\
\text { Aluna 32, Aluno 35, Aluno } \\
\text { 36, Aluna 38, Aluno 42, } \\
\text { Aluna 43, Aluno 45, Aluno } \\
\text { 46, Aluna 48, Aluna 50, } \\
\text { Aluna 51, Aluna 52 }\end{array}$ & \multirow{2}{*}{25} & \multirow{2}{*}{$47 \%$} \\
\hline
\end{tabular}

Fonte: Elaboração Ketlin E. T. W. Fiocco

O Debate Regrado instaura por meio da oralidade enquanto gênero textual, uma oportunidade aos alunos de considerar posições alternativas e diversas para um mesmo problema, possibilitando que ampliem o campo mental e o modo que se relacionam com os fenômenos estudados e aprendidos na escola.

\subsection{Articulação de diferentes gêneros textuais pelos alunos no Debate Regrado e no texto escrito}

Durante a aplicação da SD os alunos tiveram a oportunidade de acessarem diversos gêneros discursivo-textuais com o objetivo de apoiá-los na elaboração da base de conhecimentos necessários para que fossem capazes de articulá-los e assim desenvolver formas de pensamento mais complexas sobre o espaço geográfico, já que estes requerem o 
suporte físico das relações socioespaciais que a Rede de Transportes demanda para ser compreendida

O ambicioso objetivo de todo o trabalho didático que apresentamos ao longo desta pesquisa de Mestrado nos levou a questionar por muitas vezes se os alunos estavam realmente aprendendo Geografia por meio de uma Sequência Didática por gêneros discursivo-textuais, o que nos exigiu uma revisão constante dos conceitos que estavam implícitos acerca da ciência e da própria Geografia no currículo escolar.

O processo de revisão constante dos conceitos e concepções presentes em nossa prática docente nos levou a questionar o que Morin (2011, p. 33) denomina como um dos saberes necessários para a educação, quais sejam, os princípios do conhecimento pertinente que consiste no problema universal de todo cidadão do novo milênio: como ter acesso às informações sobre o mundo e como ter a possibilidade de articulá-las e organizá-las?

Destarte, o princípio do conhecimento pertinente, de articulação e organização das informações sobre o mundo, recebeu maior importância quando mediamos os alunos na articulação de diferentes gêneros discursivo-textuais em seus próprios enunciados num momento em que as informações estão fragmentadas e desarticuladas.

O desafio é trabalhar didaticamente e ensinar aos alunos a possibilidade de articular as informações e as ideias que compõem os discursos de diferentes autores na elaboração de pensamentos por conceitos, de maneira a auxiliá-los a pensar de diferentes formas sobre os fenômenos da realidade, o que para Morin $(2007$, p. 6) "trata-se de exercer um pensamento capaz de lidar com o real, de com ele dialogar e negociar".

Ao olharmos para a Geografia e o modo como está sendo pensada na escola, Claval (2014, p. 21) se referindo ao trabalho do geógrafo, destaca duas exigências:

O trabalho do geógrafo é sempre complexo. Não se resume a alguns métodos elementares. Nasce da confrontação permanente de duas exigências. A primeira destaca o espaço, nas relações que se estabelecem, em cada meio e no papel da distância na vida coletiva. A segunda leva sistematicamente a efeito, num contexto espacial, os instrumentos e as categorias imaginadas pelas outras disciplinas para explorar o seu próprio campo.

Como professora de Geografia, pensamos o espaço na perspectiva da complexidade do ensino e dos esforços que temos que empreender para que os alunos tenham a oportunidade de operar com o objeto da Geografia de maneira que o espaço geográfico se constitua como conhecimento pertinente e para isso é preciso evidenciar (MORIN, 2011, p. 34):

- o contexto;

- o global; 
- o multidimensional;

- o complexo.

Para Morin (2011, p. 33-34) o problema universal pela busca do conhecimento pertinente se confronta com a educação por meio de práticas que refletem as inadequações cada vez mais amplas, profundas e graves entre, de um lado, os saberes desunidos, divididos, compartimentados, e, de outro lado, as realidades ou os problemas cada vez mais multidisciplinares, transversais, multidimensionais, transnacionais, globais e planetários.

$\mathrm{Na}$ busca de possíveis respostas para nossa indagação frente às inúmeras informações que os alunos tiveram acesso durante os meses de agosto a novembro do ano letivo de 2013, por meio dos esforços empreendidos de planejamento, elaboração e aplicação da SD "O Brasil vai de quê?" é que organizamos os enunciados dos alunos durante os turnos de DR identificando quais discursos serviram como base do conhecimento que estavam elaborando durante as aulas de Geografia.

Quadro 18 - Gêneros discursivo-textuais que apoiaram os alunos durante o Debate Regrado.

\begin{tabular}{|l|l|c|c|}
\hline \multicolumn{1}{|c|}{$\begin{array}{c}\text { Discursos que circularam } \\
\text { durante o debate }\end{array}$} & \multicolumn{1}{|c|}{ Alunos } & $\begin{array}{c}\text { Quantidade de } \\
\text { referências }\end{array}$ & Proporção \\
\hline $\begin{array}{l}\text { Apoiou-se nas informações do } \\
\text { texto: Transporte Multimodal } \\
\begin{array}{l}\text { é a melhor opção para o } \\
\text { Brasil. }\end{array}\end{array}$ & $\begin{array}{l}\text { Aluno 4, Aluna 14, } \\
\text { Aluna 18, Aluna 20, } \\
\text { Aluno 22, Aluna 38, } \\
\text { Aluna 43, Aluno 47 }\end{array}$ & 8 & $21 \%$ \\
\hline $\begin{array}{l}\text { Apoiou-se nas informações do } \\
\text { texto: Análise do setor de } \\
\text { transportes. }\end{array}$ & Aluna 14, Aluno 25 & 2 & $5 \%$ \\
\hline $\begin{array}{l}\text { Apoiou-se nas informações do } \\
\text { mapa Rede Multimodal de } \\
\text { transportes 2002. }\end{array}$ & Aluna 51 & 1 & $3 \%$ \\
\hline $\begin{array}{l}\text { Apoiou-se nos exemplos da } \\
\text { própria experiência. }\end{array}$ & $\begin{array}{l}\text { Aluna 38, Aluno 24, } \\
\text { Aluno 37, Aluna 31, } \\
\text { Aluna 39, Aluna 40, } \\
\text { Aluno 49 }\end{array}$ & 7 & $18 \%$ \\
\hline $\begin{array}{l}\text { Apoiou-se em exemplos da } \\
\text { pesquisa sobre a rede de } \\
\text { transportes de outros países. }\end{array}$ & $\begin{array}{l}\text { Aluna 26, Aluno 36 B., } \\
\text { Aluno 25, Aluno 47 }\end{array}$ & 5 & $16 \%$ \\
\hline $\begin{array}{l}\text { Passa a utilizar de } \\
\text { informações das falas dos } \\
\text { colegas durante o Debate } \\
\text { Regrado. }\end{array}$ & $\begin{array}{l}\text { Aluno 16, Aluno 27, } \\
\text { Aluno 28, Aluna 29, } \\
\text { Aluno 35, Aluno 49 }\end{array}$ & 6 & $24 \%$ \\
\hline Não foi possível identificar. & $\begin{array}{l}\text { Aluno 5, Aluno 6, Aluna } \\
\text { 29, Aluna 32, Aluno 33, } \\
\text { Aluno 41, Aluno 45, } \\
\text { Aluna 48, Aluna 52 }\end{array}$ & 9 & $100 \%$ \\
\hline Totais & 20 & \\
\hline
\end{tabular}

Fonte: Elaboração Ketlin E. T. W. Fiocco. 
$\mathrm{Na}$ análise realizada dos discursos que circularam durante os turnos de DR nos chamam a atenção a diversidade e a riqueza dos gêneros que os alunos puderam acessar de acordo com o sentido e o significado que foi construído por cada um deles no contexto em que foi empregado.

De trinte e oito (38) referências que encontramos nas exposições orais dos alunos, destacamos as três fontes mais utilizadas: com 21\% foi a dissertação "Transporte Multimodal é a melhor opção para o Brasil", $18 \%$ de exemplos da própria experiência e $16 \%$ de informações das falas dos colegas durante o Debate Regrado.

Os dados nos indicam como o processo de elaboração do conhecimento se dá por diversas fontes, que não podem ser negligenciadas ou excluídas pela escola, mas sim mediadas por instrumentos que possibilitem a articulação de gêneros textuais nas modalidades orais e escritas, como demonstrou a utilização pelos alunos das informações do texto escrito, do texto oral, bem como os exemplos da própria experiência e que constituem a base para novos pensamentos mais complexos, como afirma Vigotski (2010, p. 243):

O acúmulo de conhecimento leva invariavelmente ao aumento de tipos de pensamento científico, o que por sua vez, manifesta no desenvolvimento do pensamento espontâneo e redunda na tese do papel prevalente da aprendizagem no desenvolvimento do aluno escolar. (Grifo nosso)

Considerando as traduções e o contexto em que Vigotski escreveu sobre suas pesquisas, o termo "acúmulo de conhecimento" não deve ser entendido por grandes volumes de conteúdos a serem memorizados sem sentido ou significado pelos alunos, reflexos de uma prática que não corresponde mais às demandas dos problemas cada vez mais multidisciplinares, transversais, multidimensionais, transnacionais, globais e planetários, mas sim como as possibilidades de articulação das informações, sobretudo da própria ciência e que desafiem o modo de pensar dos alunos.

A tarefa de articular diversas fontes de conhecimento para elaborar novas formas de pensar demanda para nós o desenvolvimento de um pensamento complexo que "é animado por uma tensão permanente entre a aspiração a um saber não fragmentado, não compartimentado não redutor, e o reconhecimento do inacabado e da incompletude de qualquer conhecimento". (MORIN, 2007, p. 7)

Para finalizar nossa análise, organizamos um quadro (Quadro 19) em que apresentamos as referências utilizadas pelos alunos em seus textos escritos depois de participarem do Debate Regrado. 
Quadro 19 - Análise da importância dos elementos do Debate Regrado para o texto escrito.

\begin{tabular}{|c|c|c|c|}
\hline $\begin{array}{c}\text { Análise da importância do } \\
\text { Debate Regrado para a } \\
\text { elaboração do texto } \\
\text { escrito }\end{array}$ & Alunos & Quantidade & Proporção \\
\hline $\begin{array}{l}\text { Passa a utilizar-se de ao } \\
\text { menos um dos textos } \\
\text { presentes nas atividades da } \\
\text { SD }\end{array}$ & $\begin{array}{l}\text { Aluno 1, Aluno 7, Aluno } \\
\text { 24, Aluna 31, Aluna 34, } \\
\text { Aluno 46. }\end{array}$ & 6 & $11 \%$ \\
\hline $\begin{array}{l}\text { Passa a articular as ideias } \\
\text { de dois ou mais textos } \\
\text { presentes nas atividades da } \\
\text { SD }\end{array}$ & $\begin{array}{l}\text { Aluna 2, Aluno 4, Aluno } \\
\text { 12, Aluna 15, Aluna 19, } \\
\text { Aluna 20, Aluna 38, } \\
\text { Aluno 22, Aluno 23, } \\
\text { Aluno 25, Aluna 26, } \\
\text { Aluno 27, Aluno 28, } \\
\text { Aluna 29, Aluna 32, } \\
\text { Aluno 35, Aluno 36 B., } \\
\text { Aluna 39, Aluno 42, } \\
\text { Aluna 43, Aluno 44, } \\
\text { Aluno 45, Aluno 49, } \\
\text { Aluna 50. }\end{array}$ & 24 & $45 \%$ \\
\hline $\begin{array}{l}\text { Prevalecem as ideias } \\
\text { baseadas nos conceitos } \\
\text { espontâneos }\end{array}$ & Aluno 41 & 1 & $2 \%$ \\
\hline $\begin{array}{l}\text { Passa a articular os } \\
\text { conceitos espontâneos às } \\
\text { ideias de textos presentes } \\
\text { nas atividades da SD }\end{array}$ & $\begin{array}{l}\text { Aluno 10, Aluno 30, } \\
\text { Aluna 52, Aluno } 53\end{array}$ & 4 & $8 \%$ \\
\hline $\begin{array}{l}\text { Passa a articular as ideias } \\
\text { dos textos da SD a outros } \\
\text { conceitos relevantes da } \\
\text { realidade }\end{array}$ & Aluna 40, Aluno 47 & 2 & $4 \%$ \\
\hline $\begin{array}{l}\text { Passa a articular as ideias } \\
\text { dos textos da SD a outras } \\
\text { informações noticiadas por } \\
\text { telejornais }\end{array}$ & Aluno 37, Aluna 38 & 2 & $4 \%$ \\
\hline $\begin{array}{l}\text { Seguiu utilizando-se de um } \\
\text { ou mais textos da SD como } \\
\text { referência }\end{array}$ & Demais alunos & 14 & $26 \%$ \\
\hline
\end{tabular}

Fonte: Elaboração Ketlin E.T.W. Fiocco.

É importante ressaltar que a terceira e última elaboração textual escrita no contexto de aplicação da SD ocorreu depois que os alunos participaram do Debate Regrado, que em nossa análise se constituiu como instrumento de mediação, pois conseguimos examinar por meio das participações orais dos alunos como estavam pensando sobre o problema da SD e assim fazer as mediações necessárias, como a busca da novidade e da complexidade. 
Do ponto de vista da utilização de referências pelos alunos para a elaboração de seus enunciados, os dados apontam que, depois do Debate, 24 alunos, ou seja, $45 \%$ deles passam a articular as ideias de dois ou mais textos presentes nas atividades da SD e que 6 alunos, ou seja, $11 \%$ passam a utilizar ao menos um dos textos presentes nas atividades da SD. Os dois dados representam mais da metade de nossa amostra corroborando para a afirmação que "urge forjar instrumentos de pensar próprios para enfrentar essa realidade complexa (...)"(POURTOIS; DESMET, 1999, p.33) e que a oralidade no contexto de nossa SD apoiou os alunos a considerarem outros pontos de vista para seus enunciados e planos de argumentação.

A Geografia, como disciplina escolar pode colaborar para o desenvolvimento do pensamento complexo por sua força temática que, por princípio, abrange a física terrestre e as relações humanas com o espaço, que segundo Morin (2002, p.32) demanda acrescentar ao espírito científico o espírito da cultura das humanidades: "não esqueçamos que a cultura das humanidades favorece a aptidão para a abertura a todos os grandes problemas, para meditar sobre o saber e para integrá-lo à própria vida, de modo a melhor explicar, correlativamente, a própria conduta e o conhecimento de si”. 


\section{CONSIDERAÇÕES FINAIS}

Iniciamos nossa pesquisa buscando encontrar aspectos teóricos e metodológicos que apoiassem nossas hipóteses acerca da importância da oralidade para o desenvolvimento de conceitos e aprendizagem de Geografia na Educação Básica, nos deparando com diversas possibilidades de respostas por meio da articulação dialógica entre as análises das falas dos alunos e das diversas fronteiras teóricas (MIRANDA, 2010) que percorremos como da Filosofia da Linguagem, Teoria da Experiência da Aprendizagem Mediada, da Psicologia da Aprendizagem e da própria Linguística.

Diante da complexidade da abordagem de nossa investigação e conscientes da necessidade de novos estudos e pesquisas sobre a importância da oralidade e sua relação com o Ensino de Geografia, nos detivemos a três aspectos que consideramos mudanças importantes que ocorreram durante o processo de pesquisa quanto às concepções teórica e metodológica; sendo o primeiro, a análise da fala de uma perspectiva das práticas comunicativas e do gênero discursivo-textual por meio da sua relação com a escrita; o segundo da própria concepção de Debate Regrado e o terceiro, as possíveis ações prospectivas de um ensino, que surgiram a partir da centralidade da fala do aluno e suas elaborações cognitivas mais complexas acerca dos fenômenos estudados.

A compreensão da concepção dialógica de análise da fala e da escrita (MARCUSCHI, 2001) possibilitou-nos, ora nos aproximarmos das relações entre oralidade, leitura e escrita, bem como das especificidades da própria oralidade; ora considerarmos as características próprias dos usos da língua, como plataforma comum mais eficiente de ensino (FOUCAMBERT, 2002) e, por conseguinte a inserção das diferentes disciplinas do Currículo Escolar, em especial da Geografia, nas discussões que propusemos em nossa pesquisa.

Entre os aspectos investigados de uma perspectiva de aproximação entre fala e escrita, estava a difusão da ideia acerca da necessidade de desenvolvimento da leitura e escrita na escola como compromisso e responsabilidade de todas as áreas do currículo escolar (NEVES, 1998). O contexto de resultados que demonstram níveis inadequados de proficiência dos alunos brasileiros (OECD, 2000) desencadearam políticas públicas educacionais apoiadas no paradigma das competências em que a solução para o problema é apontada como o uso de livros didáticos e a implementação de programas e referenciais que têm o objetivo de instrumentalizar os professores para o trabalho com a leitura e a escrita. 
Interessava-nos discutir sobre a tarefa dos professores de ensinar a disciplina escolar e, simultaneamente, serem responsáveis por colocar em prática aspectos que envolvessem o aprendizado e o uso da língua, que de uma maneira geral, não dominavam.

Examinamos o Referencial de Expectativas para o desenvolvimento da competência leitora e escritora no Ciclo II do Ensino Fundamental (2005), e o Caderno de Orientações Didáticas de Geografia (2005) da Rede de Ensino da Prefeitura de São Paulo (SP), que em nossa análise se apresentaram como um conjunto de técnicas de leitura em que a proposta de produção de algum gênero textual pelos alunos tinha como objetivo apoiar a interpretação e compreensão dos textos lidos.

A análise dos documentos nos possibilitou verificar que apenas a difusão das ideias e instrumentalização dos professores, do ponto de vista de um conjunto de técnicas, se apresentou pouco eficiente diante da complexidade da tarefa, que envolve conhecimentos mais aprofundados acerca do aprendizado e uso da língua (SOARES, 2004), sobretudo de aspectos da alfabetização e uma concepção de sujeito capaz de elaborar e expressar seus enunciados (BAKHTIN, 2010) por meio de gêneros discursivo-textuais nas modalidades oral e escrita.

Por conseguinte buscamos, pela aplicação de Sequências Didáticas por gêneros discursivo-textuais (SCHNEUWLY e DOLZ, 2010), articular o ensino de Geografia à oralidade inserindo turnos de Debate Regrado, com a hipótese de que apenas a participação dos alunos neste tipo de atividade seria suficiente para garantir o protagonismo e o desenvolvimento de uma postura crítica frente aos fenômenos estudados por meio da argumentação (Driver, Newton e Osborne, 2000).

A hipótese não se sustentou durante os turnos de Debate Regrado da Sequência Didática “O Brasil vai de quê?" envolvendo 77 alunos do $7^{\circ}$ ano do Ensino Fundamental II e que compõem o material empírico de análise da nossa pesquisa. De maneira geral foi possível verificar o desempenho verbal oral dos alunos caracterizado por participações episódicas, sem muitas explicações relacionadas ao assunto e acompanhadas de comportamentos impulsivos, o que ao mesmo tempo, nos apontou para a necessidade de outras ações que focalizassem durante as aulas a elaboração de conceitos (VIGOTSKI, 2010) pelos alunos e um ensino de Geografia que considere o funcionamento dos sujeitos no mundo em função de suas aspirações, de seus sonhos e de suas antecipações no espaço geográfico que ocupam (CLAVAL, 2013).

A análise do desempenho verbal oral dos alunos nos desafiou a uma revisão para além dos aspectos caóticos da oralidade, o que demandou estabelecer outros critérios de análise, 
como a relação da oralidade com a escrita o que nos possibilitou observar que alunos que apresentaram menos recursos verbais orais durante o Debate Regrado posteriormente, na elaboração escrita, apoiaram-se em novas palavra e conceitos, demonstrando um dos aspectos que conseguimos delinear em nossa pesquisa: o gênero discursivo-textual oral como importante instrumento de mediação (FEUERSTEIN, 2014) para o professor, por meio das falas dos alunos.

Entre os critérios de análise estiveram presentes, a importância das palavras para a elaboração dos conceitos (VIGOTSKI, 2010). Nossa observação evidenciou que a simples apresentação delas em uma lista exposta na sala de aula não garantiu aos alunos sua utilização oral durante o Debate Regrado, ou seja, não apoiou os alunos no desenvolvimento de tipos de pensamento com níveis mais elevados de abstração e generalização.

Para que o ensino possa apoiar os alunos em suas elaborações mais planejadas de fala e pensamento, identificamos a necessidade de instrumentos que, em contrapartida, apoiem o professor na mediação do conhecimento relacionado à Geografia por meio dos gêneros orais que, diferentemente da modalidade escrita, são elaborados no contexto tenso da fala, ou seja, o texto oral é produzido na ação dos sujeitos.

Dentre os instrumentos de mediação da elaboração do gênero discursivo-textual oral destacamos o uso de equipamentos de gravação audiovisual como ferramenta importante de avaliação do processo de elaboração dos gêneros pelos próprios alunos, que no movimento de revisão do próprio gênero oral em uma situação de aprendizagem dos elementos estáveis e dos próprios conhecimentos científicos envolvidos podem propiciar novas aprendizagens.

Outra constatação de nossa análise foi acerca da necessidade de revisão do próprio conceito de Debate não apenas como embate político, mas sim como oportunidade e espaço de favorecimento à elaboração de novas ideias e conhecimentos por meio da consideração e análise de diversos pontos de vista, o que podemos chamar de uma postura dialógica da construção do conhecimento, por meio de um gênero público oral (SCHNEUWLY e DOLZ, 2010).

Dessa maneira, em nossa análise o Debate Regrado passou a ser concebido como parte do complexo processo de aprendizagem de Geografia, de regras do pensamento e do próprio gênero oral inserido em uma concepção de Ciência Viva (MORIN, 2012; BALIBAR, 2012).

Os dados de nossa análise indicaram a necessidade da garantia de espaços da aula que privilegiem e desafiem a fala dos alunos, organizadas em enunciados cada vez mais complexos por meio de diversos gêneros discursivo-textuais da modalidade oral, pois verificamos que com apenas um gênero discursivo-textual oral mais estruturado, o Debate 
Regrado, os alunos já apresentaram novas elaborações de conceitos, mudanças de pontos de vista, articulação de novos conhecimentos com elementos da própria experiência, posicionamento mais claro e preciso acerca do problema da Sequência Didática (POZO, 1998), entre outros, articulados aos textos de modalidade escrita.

Ressaltamos que por meio da escuta atenta, caracterizada por análises das falas dos alunos de maneira mais sistematizadas pelo professor que se torna um pesquisador (LUDKE, 2001) é que o gênero oral pode indicar potencialidades entre o que os alunos falam e ouvem e seus processos de elaboração e organização do pensamento para assim, apoiar mediações mais eficientes do ponto de vista do ensino de Geografia.

Entendemos que os gêneros discursivo-textuais orais são possibilidades reais do processo de organização e expressão dos enunciados quando mediados pelo professor, além de contribuir para o desenvolvimento de estruturas cognitivas mais elaboradas, levando-os a pensar de maneira contextualizada e complexa, demandas tão próprias da formação contemporânea de sujeito, considerando os critérios culturais (TOURAINE, 2011). 


\section{REFERÊNCIAS}

ALEXANDRE, M. P.; AGRASO, M. F. A argumentação sobre questões sociocientíficas: Processos de construção e justificação do conhecimento em sala de aula. Educação em Revista. v. 43. Belo Horizonte: Minas Gerais: 2006. pp. 13-33.

AMORIM, M. O pesquisador e seu outro: Bakhtin nas Ciências Humanas. São Paulo: Musa Editora, 2004.

BAKHTIN, M. Os gêneros do discurso. In: Estética da criação verbal. Trad. Paulo Bezerra. 4 ed. São Paulo: Martins Fontes, 2010, p. 261-306.

O problema do texto na Linguística, na filologia e em outras ciências Humanas. In: BAKHTIN, M. Estética da criação verbal. Trad. Paulo Bezerra. 4 ed. São Paulo: Martins Fontes, 2010, p. 307-335.

Apontamento de 1970-1971. In: BAKHTIN, M. Estética da criação verbal. Trad. Paulo Bezerra. 4 ed. São Paulo: Martins Fontes, 2010, p. 367-392.

. Metodologia das Ciências Humanas. In: BAKHTIN, M. Estética da criação verbal. Trad. Paulo Bezerra. 4 ed. São Paulo: Martins Fontes, 2010, p. 391-410.

BALIBAR, S. A física numa escala humana. In: MORIN, Edgar. A religação dos saberes: o desafio do século XXI. 10 ${ }^{\text {a }}$ Ed. Rio de Janeiro: Bertrand Brasil, 2012. p.60-68.

BAUMAN, Z. 44 cartas do mundo líquido moderno. Rio de Janeiro: Zahar, 2011.

Zahar, 2013.

Sobre educação e juventude: conversas com Ricardo Mazzeo. Rio de Janeiro:

BOURDIEU, P. (org.). A Miséria do Mundo. Petrópolis: Vozes, 2012.

BRAIT, B.; CAMPOS, M. I. Da Rússia czarista à web. In: BRAIT, B. (org.) Bakhtin e seu Círculo. São Paulo: 2009. pp.15-29.

PCNs, gêneros e ensino de língua: faces discursivas da textualidade. In: ROJO, R. (org.). A prática de linguagem em sala de aula: praticando os PCNs. Campinas, SP: Mercado de Letras, 2000. pp. 15-25.

BRAIT, B.; SOUZA-E-SILVA, M. C. (orgs.). Perspectiva dialógica. In: Texto ou discurso? São Paulo: Contexto, 2012.

BRANDIST, C. Os círculos de Vigotski e Bakhtin: explicando a convergência. In: Repensando o Círculo de Bakhtin: Novas perspectivas na história intelectual. São Paulo: Contexto, 2012.

CALKINS, L. M. A arte de ensinar a escrever: o desenvolvimento do discurso escrito. Porto Alegre: Artes Médicas, 1989.

CHALMERS, A. F. O que é ciência afinal? Tradução Raul Fiker. São Paulo: Brasiliense, 1993. 
CLAVAL, P. Terra dos Homens: a geografia. São Paulo: Contexto, 2010.

. Uma agenda para a Geografia. In: SILVA, J. B. É geografia, é Paul Claval. Goiânia: FUNAPE, 2013. pp. 144-160. Disponível em: $<$ http://projetos.extras.ufg.br/posgeo/wp-content/uploads/2013/09/e-geografia_e-paulclaval.pdf $>$. Acesso em 06/01/2014.

Epistemologia da Geografia. Florianópolis: Ed. da UFSC, 2014.

COSTA, S. R. A construção de "títulos" em gêneros diversos: um processo discursivo e plurissêmico. In: ROJO, R. (Org.). A prática de linguagem em sala de aula: praticando os PCNs. Campinas, SP: Mercado de Letras, 2000. p. 67-90.

COSTA, S. R. Dicionário de gêneros textuais. Belo Horizonte: Autêntica Editora, 2009.

ERHART, S.; PALMEIRA E. M. Análise do Setor de Transportes. In: Observatorio de la Economía Latinoamericana, Número 71, 2006. Disponível em: <http://www.eumed.net/cursecon/ecolat/br/06/semp.htm.>. Acesso em 06/05/2016.

DOLZ, J. Os cinco grandes desafios da Língua Portuguesa. São Paulo. Seminário Internacional Escrevendo o Futuro. 2015. (Comunicação oral) Disponível em: $<$ https://www.youtube.com/watch?v=K68WLhIcSrc>. Acesso em 25/10/2016.

DEHAENE, S.; COHEN, Cultural Recycling of Cortical Maps. In: Neuron, $\mathrm{n}^{\circ}$ 56, October 25, 2007. Cambridge (MA): Cell Press. p. 384-98.

DRIVER, R.; NEWTON, P.; OSBORNE, J. Establishing the norms of Scientific Argumentation in Classrooms. Journal Science Education, vol. 84, p. 287-312, 2000. Disponível em: $<$ https://cset.stanford.edu/sites/default/files/files/documents/publications/OsborneEstablishing $\% 20$ the \%20Norms\%20of\%20Scientific\%20Argumentation.pdf.> Acesso em 02/02/ 2013.

FEUERSTEIN, R. Além da inteligência: aprendizagem mediada e a capacidade de mudança do cérebro. Petrópolis, RJ: Vozes, 2014.

FIORIN, J. L. Da necessidade da distinção entre texto e discurso. In: Texto ou discurso? São Paulo: Contexto, 2012, p.145-165.

FONSECA, V. Aprender a aprender: a educabilidade cognitiva. Porto Alegre: Artmed, 1998.

FOUCAMBERT, J. A criança, o professor e a leitura. Porto Alegre: Artes Médicas, 1997.

CLIFFORD G. O saber local: novos ensaios em antropologia interpretativa. $2^{\mathrm{a}}$ ed. Petrópolis, Rio de Janeiro: Vozes, 1999.

GEORGE, P. Os métodos da Geografia. Tradução Heloysa de Lima Dantas. São Paulo: Difusão Europeia do Livro, 1972. Problemas, doutrina e método. In: A Geografia ativa. São Paulo: DIFEL, 1980. 
GOMES, C. M. A. Feuerstein e a construção do conhecimento. Porto Alegre: Artmed, 2002.

GOMES-SANTOS, S. N. A exposição Oral: nos anos iniciais do ensino fundamental. São Paulo: Cortez, 2012.

GUEDES, P. C., SOUZA, J. M. Leitura e escrita são tarefas da escola e não só do professor de português. In: NEVES, I. C. et al. (orgs.) Ler e escrever: compromisso de todas as áreas. Porto Alegre, RS: Editora da UFRGS, 1998.

INFANTE, I. O analfabetismo funcional na América Latina: Algumas características a partir de uma pesquisa regional. Encontro latino-americano sobre educação de jovens e adultos trabalhadores. Brasília, Inep, 1994.

KANAWATI, L. M. Os contextos de aprendizagem da linguagem em sequências didáticas de geografia na Revista Nova Escola. Artigo apresentado à disciplina de Práticas de Linguagem em contextos de ensino-aprendizagem, 2013. No prelo.

KONDO, M. M. Transporte multimodal é a melhor opção para o Brasil. 16/02/2005. Disponível em: <http://vestibular.uol.com.br/resumo-das-disciplinas/geopolitica/transportemultimodal-e-a-melhor-opcao-para-o-brasil.htm.>. Acesso em: 04/09/16.

KOZULIN, A. Instrumentos Psicológicos - La educación desde una perspectiva sociocultural. Barcelona: Ediciones Paidós Ibérica S.A, 2000.

LIMA, S. M. Concepção bakhtiniana de linguagem e de gênero discursivo: uma análise das orientações curriculares de língua portuguesa para o ensino médio. Entretextos, v.12, n.1, p.164-177, Londrina, Paraná: jan./jun. 2012.

LÜDKE, M. Pesquisa em educação: conceitos, políticas e práticas. In: GERALDI, C.M.; FIORENTINI, D.; PEREIRA, E.M. (org.). Cartografias do trabalho docente: professor(a)pesquisador(a). Campinas, SP: Mercado de Letras, 1998.

. (coord.) O professor e sua pesquisa. São Paulo: Papirus, 2001.

(coord.) O que conta como pesquisa? São Paulo: Editora Cortez, 2009.

LURIA, A. R. Pensamento e linguagem: as últimas conferências de Luria. Porto Alegre: Artes Médicas, 1986.

MACEDO, F. G. O lugar do mapa no ensino e aprendizagem de geografia: a questão de escala na formação de professores. Dissertação de Mestrado. Universidade de São Paulo Programa de Pós-Graduação em Geografia Humana. São Paulo. Brasil, 2014.

MARCUSCHI, L. A. Análise da conversação. São Paulo: Ática, 1986. (Série Princípios).

Nove teses para uma reflexão sobre a valorização da fala no ensino de língua - A propósito dos Parâmetros Curriculares no Ensino de Língua Portuguesa de $1^{\mathrm{a}}$ a $4^{\mathrm{a}}$ série do $1^{\mathrm{o}}$ grau menor. Revista ANPOLL, Florianópolis (SC), v.1, nº 4, p.137-156, jan/JUN. 1998. Disponível em: <http://www.anpoll.org.br/revista/index.php/revista/article/view/284/297.> Acesso em 26 mar. 2014. 
Oralidade e escrita. Revista Signótica, Goiânia (GO), no 9, p.119-145, jan/dez. 1997. Disponível em: <http://www.revistas.ufg.br/index.php/sig/article/view/7396/5262.> Acesso em 26/03/2014.

Breve excurso sobre a Linguística no século XX. In: MARCUSCHI. L.A. Produção textual, análise de gêneros e compreensão. São Paulo: Parábola Editorial, 2008. p.25-46.

Da fala para a escrita: atividades de retextualização. São Paulo: Cortez, 2001.

MENEZES, E. T.; SANTOS, T. H. Verbete avaliação somativa. In: Dicionário Interativo da Educação Brasileira: Educabrasil. São Paulo: Midiamix, 2001. Disponível em: <http://www.educabrasil.com.br/avaliacao-somativa.> Acesso em: 25/10/ 2016.

MIRANDA, M. E. Contribuição ao debate atual sobre a formação de professores no Brasil: pela formação de futuras gerações na perspectiva da reconstrução do sociocultural. Revista do Departamento de Geografia, n 20. São Paulo: USP, 2010.

A Reinvenção da Prática Docente: interfaces e aproximações. Anais eletrônicos do XIII Encontro de Geógrafos da América Latina. Lima, Peru, 2013. Disponível em: <http://www.egal2013.pe/wp-content/uploads/2013/07/Tra_Maria-Eliza-Miranda.pdf>. Acesso em 26/03/2014.

Revolução Cognitiva, Aprendizagem Mediada e importância da Geografia na Educação Básica. São Paulo: Catálogo das disciplinas USP. Criada em: 09 dez. 2009. Disponível em:

$<$ https://uspdigital.usp.br/janus/componente/catalogoDisciplinasInicial.jsf?action=3\&sgldis=F LG5101>. Acesso em 04/03/2014.

MOLINA, O. Ler para aprender: desenvolvimento de habilidades de estudo. São Paulo: Editora Pedagógica e Universitária Ltda., 1992.

MONBEIG, P. Papel e Valor do Ensino da Geografia e de sua Pesquisa. IBGE - Conselho Nacional de Geografia, Rio de Janeiro. 1956.

MORAIS, J. Criar leitores para uma sociedade democrática. In: Signo. Santa Cruz do Sul: jul. dez. 2013, v. 38, Especial, pp. 02-28.

MOREIRA, R. O discurso do avesso: para a crítica da Geografia que se ensina. São Paulo: Contexto, 2014.

MORIN, E. Meus demônios. Tradução Leneide Duarte e Clarisse Meireles. Bertrand, 1997.

Ciência com consciência. 3 ed. Tradução Maria D. Alexandre e Maria Alice Sampaio Dória. Rio de Janeiro: Bertrand, 1999.

A cabeça bem feita. 7 ed. Tradução Eloá Jacobina. Rio de Janeiro: Bertrand Brasil, 2002.

Introdução do pensamento complexo. 3 ed. Tradução Eliane Lisboa. Porto Alegre: Sulina, 2007. 
Os sete saberes necessários à educação do futuro. 2 ed. Tradução Catarina Eleonora F. da Silva e Jeanne Sawaya. São Paulo: Cortez; Brasília, DF: UNESCO, 2011.

Introdução às jornadas temáticas. In: MORIN, Edgar. A religação dos saberes: o desafio do século XXI. 10 ed. Rio de Janeiro: Bertrand Brasil, 2012.

NONNON, E. Note de synthèse - L'enseignement de l'oral et les interactions verbales en classe : champs de référence et problématiques - Aperçu des ressources en langue française. Revue française de pédagogie, v. 129, 1999. L'école pour tous: conditions pédagogiques, institutionnelles et sociales. p. 87-131.

OECD - ORGANISATION FOR ECONOMIC CO-OPERATION AND DEVELOPMENT. PISA 2000: Technical Report. Paris/França, 2002. Disponível em: <http://www.oecd.org/edu/school/programmeforinternationalstudentassessmentpisa/33688233 .pdf.> Acesso em 25 out. 2016.

PIAGET, J. A situação das ciências do homem no sistema das ciências. 3 Ed. Tradução Isabel Cárdigos dos Reis. Portugal: Livraria Bertrand, 1976.

Problemas de Psicologia Genética. In: Os pensadores: Jean Piaget 1896. São Paulo: Abril Cultural, 1978, p.209-294.

POURTOIS, J. P.; DESMET, H. A educação pós-moderna. São Paulo: Loyola, 1999. 311 p.

POZO, J. I. (org.) A solução de Problemas - Aprender a resolver, resolver para aprender. Porto Alegre: Artmed, 1998.

PRESTES, Z. Fala virou linguagem. In: PRESTES, Z. "Quando não é quase a mesma coisa" - Análise de traduções de Lev Semionovitch Vigotski no Brasil: repercussões no campo educacional. Tese de Doutorado apresentada ao Programa de Pós-Graduação em Educação. Brasília, Universidade de Brasília (UNB), 2010. p. 176-183.

QUINTILIANO, J. G. Gênero Discursivo e tipo textual. In: DECAT, M. A.; BITTENCOURT, V. O. Revista Scripta: Lingüística e Filologia. v. 2, n. 4. Belo Horizonte: PUC Minas, 1999. p. 87-106.

REPÚBLICA FEDERATIVA DO BRASIL. Lei de Diretrizes de Bases da Educação Nacional, $\quad \mathbf{n}^{\mathbf{9}} \quad \mathbf{9 6 9 4 / 9 6}$ Disponível em: <http://www.planalto.gov.br/ccivil_03/leis/19394.htm>. Acesso em 15/07/2013.

Secretaria de Educação Fundamental. Parâmetros curriculares nacionais: geografia. Secretaria de Educação Fundamental. Brasília: MEC/SEF, 1998.

Congresso Nacional. Câmara dos Deputados. Comissão de Educação e Cultura. Grupo de trabalho alfabetização infantil: os novos caminhos: relatório final. 2 ed. Brasília : Câmara dos Deputados, Coordenação de Publicações, 2007.

Ministério da Educação. O Ensino de Geografia e novas linguagens. In: Geografia: ensino fundamental (Coleção Explorando o Ensino; v. 22). Brasília: 2010. pp. 43-60. 
ROCKWELL, E. Gêneros do ensino: uma abordagem bakhtiniana. Trabalho de linguística aplicada [online]. 2012, vol.51, n.2, p.487-513. ISSN 2175-764X. Disponível em: <http://dx.doi.org/10.1590/S0103-18132012000200011.>. Acesso em 25 out. 2016.

SAGAN, C. Cosmos. Rio de Janeiro: Livraria Francisco Alves Editora, 1989.

SANTOS, M. A Natureza do Espaço - Técnica e Tempo, Razão e Emoção. 5 ed. São Paulo: Edusp, 2002.

SANTOS, W. L. P.; MORTIMER, E, F.; SCOTT, P. H. A argumentação em discussões sóciocientíficas: reflexões a partir de um estudo de caso. Revista Brasileira de Pesquisa em Educação em Ciências, Porto Alegre, v. 1, n. 1, p. 140-152, 2001.

PREFEITURA MUNICIPAL DE SÃO PAULO. Secretaria Municipal de Educação. Diretoria de Orientação Técnica. Referencial de expectativas para o desenvolvimento da competência leitora e escritora no ciclo II do ensino fundamental /São Paulo: SME/DOT 2006.

Secretaria Municipal de Educação. Diretoria de Orientação Técnica. Referencial de expectativas para o desenvolvimento da competência leitora e escritora no ciclo II: caderno de orientação didática de Geografia. Secretaria Municipal de Educação - São Paulo: SME/DOT, 2006. 68 p.

SASSERON, L. H.; CARVALHO, A. M. Construindo argumentação na sala de aula: a presença do ciclo argumentativo, os indicadores de alfabetização científica e o padrão de Toulmin. Ciênc. educ. (Bauru), Bauru, v. 17, n. 1, p. 97-114, 2011. Disponível em: <http://www.scielo.br/

scielo.php?script=sci_arttext $\&$ pid $=S 1516-73132011000100007 \& \operatorname{lng}=$ en $\& n r m=i s o .>$. Acesso em 28/10/2016.

SCHNEUWLY B., DOLZ, J. Gêneros orais e escritos na escola. Tradução e organização Roxane Rojo e Glaís Sales Cordeiro. Campinas/SP: Mercado de Letras, 2010.

; CORDEIRO, G. S. Gêneros na escola: forma escolar e ensino-aprendizagem de língua. In: 30 Olhares para o futuro, São Paulo: Escola da Vila, 2010, p. 91-97. Disponível em: <http://www.vila.com.br/html/outros/2010/revista/30_anos/revista/index.html>. Acesso em 15/03/2016.

SILVEIRA, M. R. (Org). Circulação, transportes e logísticas diferentes perspectivas. São Paulo: Outras Expressões, 2011.

SOARES, M. Letramento e alfabetização: as muitas facetas. Revista Brasileira de Educação, abril 2004, n. 25, pp. 05-17.

TOURAINE, A. Crítica da Modernidade. Petrópolis, RJ: Vozes, 1994.

Um novo paradigma. Petrópolis, RJ: Vozes, 2011.

TRAGTENBERG, M. As condições de produção da educação. In: Educação e burocracia. São Paulo: 2012. Cap. 5, p. 261-265. 
VARELA, A. Informação e Autonomia: a mediação segundo Feuerstein. São Paulo: Editora Senac, 2007.

VIGOTSKI, L. S. La prehistoria del desarrollo del lenguaje escrito. In: Obras Escogidas. Edição em língua castellana dirigida por Amelia Alvarez e Pablo Del Rio. Tradução de José Maria Bravo. v. III. Madrid, Espanha: Aprendizaje A. Machado Libros S.A, 1995.

A construção do pensamento e da linguagem. 2 ed. Tradução Paulo Bezerra. São Paulo: Editora WMF Martins Fontes, 2010.

Quarta aula: a questão do meio na pedologia. Psicologia, USP, São Paulo, v. 21, n.4, p.681-701, 2010. Tradução Márcia Pileggi Vinha. Disponível em http://www.revistas.usp.br/psicousp/article/view/42022/4569 Acesso em 18/02/2015.

WERTSCH, J. V., RÍO, P. D. e ALVAREZ, A. Sociocultural studies: history, action, and mediation. In.: Sociocultural studies of mind. Cambridge: Cambridge University Press, 1995. Disponível em: <http://catdir.loc.gov/catdir/samples/cam031/94034685.pdf>. Acesso em 23/10/2016.

ZANDWAIS, A. Da língua ao discurso nos limites da sintaxe: as tênues fronteiras entre discursos citados e citantes. Bakhtiniana, São Paulo, v. 1, n.5, p. 4-19, $1^{\circ}$ semestre 2011. Disponível em: <http://revistas.pucsp.br/index.php/bakhtiniana/article/view/5313/5086.>. Acesso em 19/02/2014. 


\section{APÊNDICE}

\section{Apêndice A - Termo de Consentimento Livre e Esclarecido - TCLE}

\section{TERMO DE CONSENTIMENTO LIVRE E ESCLARECIDO - TCLE}

\section{Esclarecimentos}

Estamos solicitando a autorização para que o menor pelo qual você é responsável participe da pesquisa: A palavra falada e a aprendizagem de conceitos em aulas de Geografia na Educação Básica (título provisório), que tem como pesquisadora responsável a professora Ketlin Elisa Thomé Wenceslau Fiocco, mestranda do Programa de Pós-Graduação, do Departamento de Geografia da Faculdade de Filosofia, Ciências e Letras da Universidade de São Paulo (USP).

Esta pesquisa pretende discutir a importância da palavra falada para 0 desenvolvimento de conceitos e a formação discursiva na aula de Geografia num processo didático de aplicação de Sequência Didática de Geografía.

O motivo que nos leva a fazer este estudo é pesquisar como incrementar as atividades em aula que valorizem a palavra falada para contribuir no ensino e aprendizagem de Geografia e ao mesmo tempo, configurar uma qualidade maior ao processo escolar.

Caso você decida autorizar serão utilizadas as participações gravadas em mídia audiovisual do(a) aluno(a) nos turnos de Debate Regrado nas aulas de Geografia da $6^{2}$ série $/ 7^{\circ}$ ano em 2013, bem como as produções textuais elaboradas na mesma Sequência Didática.

Os dados, bem como o direito de imagem e fala serão confidenciais e divulgados apenas em congressos ou publicações cientificas, não havendo divulgação de nenhum dado que possa identificá-lo(a).

Você tem o direito de recusar sua autorização, caso julgue necessário que isto ocorra, sem nenhum prejuizo para você e para o aluno participante.

Este documento foi impresso em duas vias. Uma ficará com você e a outra com a pesquisadora responsável.

Consentimento Livre e Esclarecido

$\mathrm{Eu}$,

$\mathrm{RG} \mathrm{n}^{\circ}$ representante legal do (a) menor autorizo sua participação na pesquisa

A palavra falada e a aprendizagem de conceitos em aulas de Geografia na Educação Básica (titulo provisório)

Esta autorização foi concedida após os esclarecimentos que recebi sobre os objetivos, importância e o modo como os dados coletados serão utilizados.

Autorizo, ainda, a publicação das informações fornecidas por ele (a) em congressos e/ou publicações cientificas, desde que os dados apresentados não possam identificá-lo(a).

São Paulo, de abril de 2015 .

Pesquisadora Responsável

Responsável pelo aluno (a) participante da Pesquisa

Aluno participante da Pesquisa 
Apêndice B - ANÁLISE DO REFERENCIAL DE EXPECTATIVAS PARA O DESENVOLVIMENTO DA COMPETÊNCIA LEITORA E ESCRITORA NO CICLO II: CADERNO DE ORIENTAÇÕES DIDÁTICAS DE GEOGRAFIA

\begin{tabular}{|c|c|c|c|c|c|c|c|c|c|}
\hline \multicolumn{10}{|c|}{$\begin{array}{l}\text { ANÁLISE DO REFERENCIAL DE EXPECTATIVAS PARA O DESENVOLVIMENTO DA COMPETENCIA LEITORA E } \\
\text { ESCRITORA NO CICLO II DO ENSINO FUNDAMENTAL / } \\
\text { São Paulo: SME/DOT } 2006\end{array}$} \\
\hline \multirow{4}{*}{ 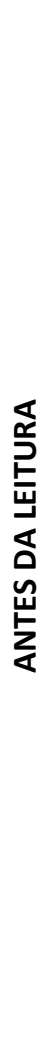 } & \multirow[b]{2}{*}{ Página } & \multirow{2}{*}{$\begin{array}{l}\text { Habilidade } \\
\text { /Expectativa de } \\
\text { aprendizagem }\end{array}$} & \multicolumn{2}{|c|}{ Competência } & \multirow[b]{2}{*}{ Instruções } & \multicolumn{2}{|c|}{ Ação } & \multirow{2}{*}{$\begin{array}{l}\text { Orientações específica } \\
\text { para a Geografia e ou } \\
\text { Ciências }\end{array}$} & \multirow[b]{2}{*}{ Observações } \\
\hline & & & Leitora & Escritora & & Professor & Aluno & & \\
\hline & \multirow[t]{2}{*}{14} & \multirow{2}{*}{$\begin{array}{l}\text { Levantamento do } \\
\text { conhecimento } \\
\text { prévio sobre o } \\
\text { assunto. }\end{array}$} & \multirow[t]{2}{*}{1} & & $\begin{array}{l}1 \text { - "levantar suas } \\
\text { hipóteses a respeito dos } \\
\text { conhecimentos que supõe } \\
\text { que a turma já dispõe a } \\
\text { respeito do assunto ou do } \\
\text { próprio texto" }\end{array}$ & 1 & & \multirow{2}{*}{$\begin{array}{l}\text { "é possível agrupar } \\
\text { informações do texto a } \\
\text { partir de categorias - de } \\
\text { lugar - na casa, na } \\
\text { fábrica, no parque, na } \\
\text { cidade, no país...; de } \\
\text { espaço (a forma que os } \\
\text { lugares assumem) - } \\
\text { doméstico, de trabalho, } \\
\text { de lazer, nacional...; de } \\
\text { paisagem - localizando, } \\
\text { descrevendo, } \\
\text { qualificando e } \\
\text { reconhecendo o } \\
\text { significado atribuído aos } \\
\text { espaços; de território - } \\
\text { nomeando, descrevendo } \\
\text { e recortando territórios a } \\
\text { partir da qualificação de } \\
\text { paisagens etc.". }\end{array}$} & \\
\hline & & & & & $\begin{array}{l}2 \text { - Organize o registro do } \\
\text { que os estudantes falam a } \\
\text { respeito do assunto } \\
\text { agrupando os dados ou } \\
\text { ideias segundo as categorias } \\
\text { de análise da disciplina }\end{array}$ & 1 & 1 & & $\begin{array}{l}\text { Consideramos como ação } \\
\text { dos alunos "falar" a respeito } \\
\text { do assunto, por isso esta } \\
\text { instrução contempla ações } \\
\text { tanto do professor quanto } \\
\text { do aluno }\end{array}$ \\
\hline
\end{tabular}




\begin{tabular}{|c|c|c|c|c|c|c|c|}
\hline \multirow[b]{3}{*}{22} & \multirow{3}{*}{$\begin{array}{l}\text { Definição dos } \\
\text { objetivos da } \\
\text { leitura. }\end{array}$} & \multirow[b]{3}{*}{1} & $\begin{array}{l}\text { 1 - Explicite claramente os } \\
\text { propósitos que orientam a } \\
\text { leitura e estimule os } \\
\text { estudantes a } \\
\text { focalizarem as informações } \\
\text { essenciais que o texto traz. }\end{array}$ & 1 & 1 & & $\begin{array}{l}\text { Consideramos como ação } \\
\text { dos alunos "focalizar" as } \\
\text { informações essenciais do } \\
\text { texto, por isso esta } \\
\text { instrução contempla ações } \\
\text { tanto do professor quanto } \\
\text { do aluno }\end{array}$ \\
\hline & & & & & & & \\
\hline & & & $\begin{array}{l}2 \text { - Proponha } \\
\text { as mesmas questões para } \\
\text { textos diferentes. (...)os } \\
\text { estudantes poderão } \\
\text { confrontar as perspectivas } \\
\text { dos autores dos textos } \\
\text { selecionados. }\end{array}$ & 1 & 1 & $\begin{array}{l}\text { "questões a respeito das } \\
\text { relações que autor do } \\
\text { texto estabelece com o } \\
\text { lugar analisado ou } \\
\text { descrito podem } \\
\text { propiciar bons debates } \\
\text { sobre diferenças e } \\
\text { semelhanças entre suas } \\
\text { concepções, olhares, } \\
\text { fundamentos teóricos e } \\
\text { identidades". }\end{array}$ & $\begin{array}{l}\text { Consideramos como ação } \\
\text { dos alunos "confrontar" as } \\
\text { perspectivas dos autores } \\
\text { dos diferentes textos, por } \\
\text { isso esta instrução } \\
\text { contempla ações tanto do } \\
\text { professor quanto do aluno }\end{array}$ \\
\hline
\end{tabular}




\begin{tabular}{|c|c|c|c|c|c|c|c|c|c|}
\hline \multicolumn{10}{|c|}{$\begin{array}{l}\text { ANÁLISE DO REFERENCIAL DE EXPECTATIVAS PARA O DESENVOLVIMENTO DA COMPETÊNCIA LEITORA E } \\
\text { ESCRITORA NO CICLO II DO ENSINO FUNDAMENTAL / } \\
\text { São Paulo: SME/DOT } 2006\end{array}$} \\
\hline \multirow{4}{*}{ 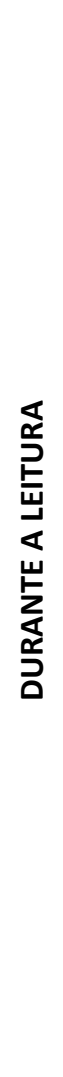 } & \multirow{2}{*}{ Página } & \multirow{2}{*}{$\begin{array}{l}\text { Habilidade } \\
\text { /Expectativa de } \\
\text { aprendizagem }\end{array}$} & \multicolumn{2}{|c|}{ Competência } & \multirow{2}{*}{ Instruções } & \multicolumn{2}{|c|}{ Ação } & \multirow{2}{*}{$\begin{array}{c}\text { Orientações específica para } \\
\text { a Geografia e ou Ciências }\end{array}$} & \multirow{2}{*}{ Observações } \\
\hline & & & Leitora & Escritora & & Professor & Aluno & & \\
\hline & \multirow[t]{2}{*}{25} & \multirow[t]{2}{*}{$\begin{array}{l}\text { Confirmação ou } \\
\text { retificação das } \\
\text { antecipações ou } \\
\text { expectativas de } \\
\text { sentido criadas } \\
\text { antes ou durante } \\
\text { a leitura. }\end{array}$} & \multirow[t]{2}{*}{1} & & $\begin{array}{l}1 \text { - Peça aos estudantes } \\
\text { para manterem à mão as } \\
\text { anotações que tiverem } \\
\text { feito antes da leitura para } \\
\text { que possam consultá-las } \\
\text { quando desejarem. Caso } \\
\text { tenha elaborado um } \\
\text { registro coletivo, } \\
\text { assegure que todos } \\
\text { disponham de uma cópia } \\
\text { ou então transcreva-o em } \\
\text { cartaz afixando-o em } \\
\text { local bem visível. }\end{array}$ & 1 & & & \\
\hline & & & & & $\begin{array}{l}2 \text { - Ao longo da leitura } \\
\text { instigue a confrontação } \\
\text { entre as hipóteses iniciais } \\
\text { e o que vão } \\
\text { identificando na leitura } \\
\text { do texto. }\end{array}$ & 1 & 1 & & $\begin{array}{l}\text { Compreendemos que as } \\
\text { ações de confrontação e } \\
\text { identificação devem ser } \\
\text { dos alunos. }\end{array}$ \\
\hline
\end{tabular}




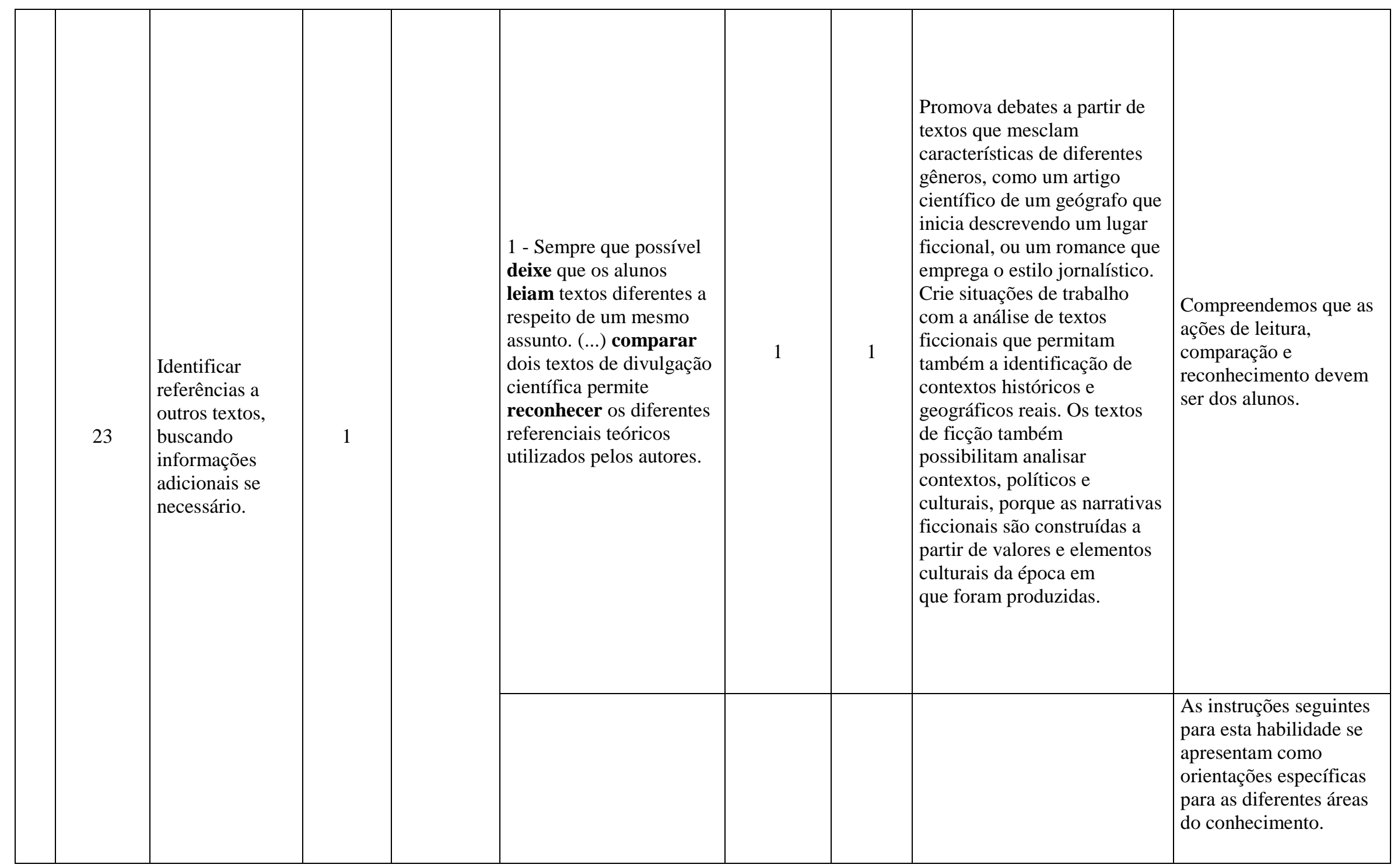




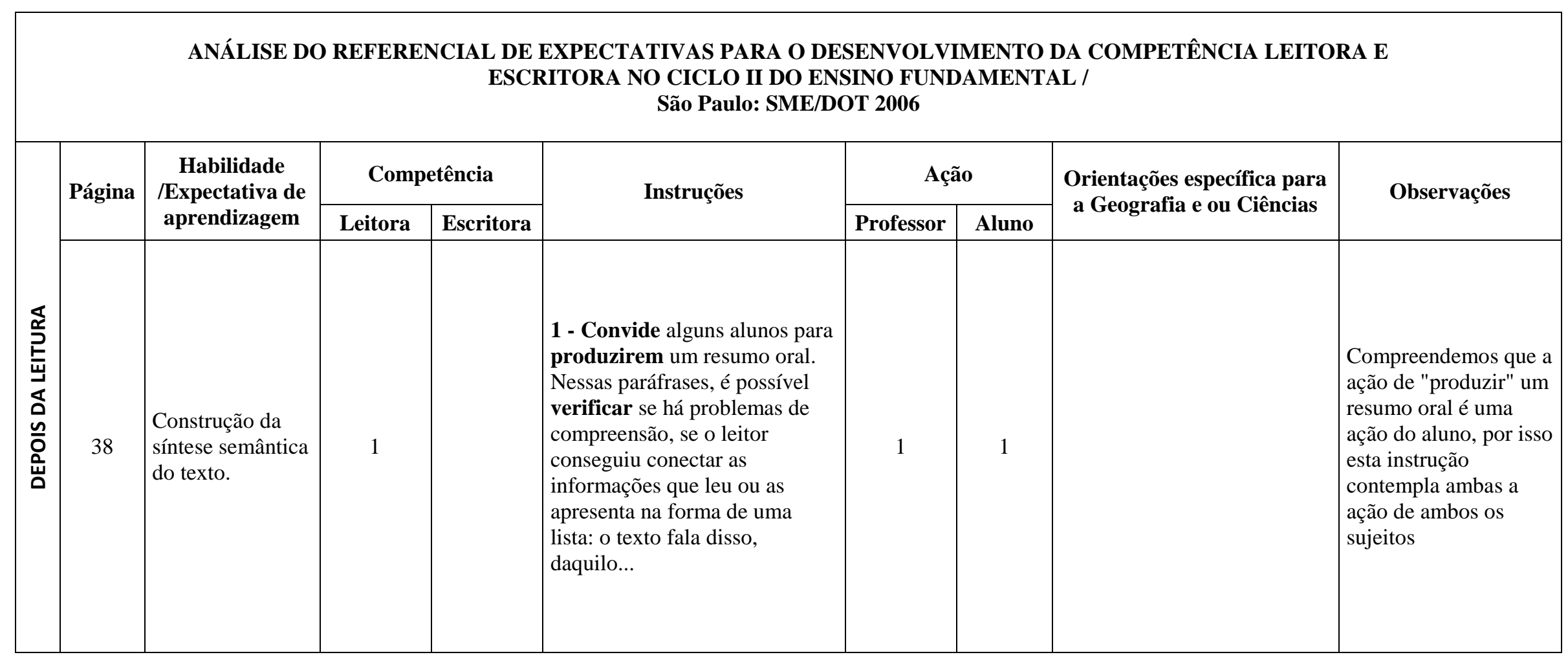




\begin{tabular}{|c|c|c|c|c|c|c|c|}
\hline & & & $\begin{array}{l}2 \text { - Identificar com os } \\
\text { estudantes os conceitos } \\
\text { presentes no texto, suas } \\
\text { definições e seus fundamentos } \\
\text { contribui para promover uma } \\
\text { leitura mais significativa, além, } \\
\text { é claro, de facilitar a } \\
\text { compreensão dos conteúdos } \\
\text { presentes naquilo que se lê. }\end{array}$ & 1 & 1 & & $\begin{array}{l}\text { Nesta instrução há } \\
\text { uma definição mais } \\
\text { clara quanto à ação } \\
\text { que deve ser tanto do } \\
\text { professor quanto do } \\
\text { aluno. }\end{array}$ \\
\hline 41 & $\begin{array}{l}\text { Avaliação crítica } \\
\text { do texto }\end{array}$ & 1 & $\begin{array}{l}1 \text { - É importante que o } \\
\text { professor possibilite ao } \\
\text { estudante expressar } \\
\text { publicamente o que pensa, } \\
\text { favorecendo a consciência de } \\
\text { seu discurso e dando } \\
\text { oportunidade para que seus } \\
\text { interlocutores possam } \\
\text { compreendê-lo melhor e } \\
\text { também com ele debater. } \\
\mathbf{2} \text { - Escolher intervenções } \\
\text { didáticas que promovam } \\
\text { discussões } \\
\text { mais abertas. Uma } \\
\text { possibilidade, por exemplo, é o } \\
\text { docente apresentar } \\
\text { alternativas } \\
\text { complementares à análise dos } \\
\text { estudantes para ser debatida } \\
\text { coletivamente. }\end{array}$ & 1 & 1 & $\begin{array}{l}\text { Textos científicos tendem a } \\
\text { empregar linguagem objetiva, } \\
\text { impessoal que mascara a } \\
\text { identificação do autor. Além } \\
\text { disso, a aceitação progressiva } \\
\text { do discurso científico como } \\
\text { sistema de conhecimento } \\
\text { confiável, muitas vezes, } \\
\text { paralisa o leitor impedindo-o } \\
\text { de problematizar de maneira } \\
\text { adequada questões como } \\
\text { ética na ciência, } \\
\text { "neutralidade" científica e } \\
\text { vulnerabilidade das teorias } \\
\text { científicas frente ao próprio } \\
\text { desenvolvimento da } \\
\text { tecnologia. Desvelar o modo } \\
\text { de construção desses textos e } \\
\text { o efeito que produzem é uma } \\
\text { alternativa para começar a } \\
\text { debater a respeito. }\end{array}$ & $\begin{array}{l}\text { Nesta instrução há } \\
\text { uma definição mais } \\
\text { clara quanto à ação } \\
\text { que deve ser do } \\
\text { professor e do aluno. }\end{array}$ \\
\hline
\end{tabular}

Fonte: Elaboração Ketlin E. T. W. Fiocco. 
Apêndice C - ANÁLISE DO REFERENCIAL DE EXPECTATIVAS PARA O DESENVOLVIMENTO DA COMPETÊNCIA LEITORA E ESCRITORA NO CICLO II: CADERNO DE ORIENTAÇÕES DIDÁTICAS DE GEOGRAFIA

\begin{tabular}{|c|c|c|c|c|c|c|c|c|}
\hline \multicolumn{9}{|c|}{$\begin{array}{c}\text { ANÁLISE DO REFERENCIAL DE EXPECTATIVAS PARA O DESENVOLVIMENTO DA COMPETENCIA } \\
\text { LEITORA E ESCRITORA NO CICLO II: CADERNO DE ORIENTAÇÃO DIDÁTICA DE GEOGRAFIA } \\
\text { SECRETARIA MUNICIPAL DE EDUCAÇÃO - SÃO PAULO } \\
\text { SME / DOT, } 2006\end{array}$} \\
\hline \multirow{2}{*}{ PÁGINA } & \multirow{2}{*}{ PROPOSTA } & \multirow{2}{*}{ INSTRUÇÕES } & \multicolumn{2}{|c|}{ SUJEITO DA AÇÃO } & \multirow{2}{*}{$\begin{array}{l}\text { GÊNERO E } \\
\text { AÇÕES } \\
\text { RELACIONDAS }\end{array}$} & \multirow{2}{*}{$\begin{array}{c}\text { CONTEÚDO } \\
\text { DOS GÊNEROS }\end{array}$} & \multirow{2}{*}{$\begin{array}{l}\text { OBJETIVO DE } \\
\text { USO/FUNÇÃO } \\
\text { DO GÊENRO }\end{array}$} & \multirow{2}{*}{ OBSERVAÇÕES } \\
\hline & & & PROF & ALUNO & & & & \\
\hline 33 & $\begin{array}{l}\text { Proposta de } \\
\text { leitura, } \\
\text { interpretação e } \\
\text { correlação de } \\
\text { informações de } \\
\text { mapas temáticos }\end{array}$ & $\begin{array}{l}\text { Antes da leitura: (A1) } \\
\text { Explore os conhecimentos } \\
\text { prévios dos alunos quanto } \\
\text { aos títulos e temas dos } \\
\text { mapas. (A2) Distribua } \\
\text { alguns atlas para os grupos } \\
\text { para que possam (A3) } \\
\text { observar os diferentes tipos } \\
\text { de mapas presentes no } \\
\text { material. (A4) Elabore } \\
\text { questões que auxiliem os } \\
\text { alunos a (A5)ampliar suas } \\
\text { expectativas sobre o } \\
\text { conteúdo dos mapas e (A6) } \\
\text { defina objetivos para sua } \\
\text { leitura } \\
\text { (A7) Retome as } \\
\text { expectativas de conteúdo } \\
\text { com base nos } \\
\text { títulos e temas dos mapas e } \\
\text { (A8) verifique se elas se } \\
\text { alteraram } \\
\text { em razão dessas novas } \\
\text { problematizações. }\end{array}$ & 4 & 2 & $\begin{array}{l}\text { G1 - Mapas - (A1) } \\
\text { (A2) (A3) (A5) } \\
\text { G2 - Exposição oral } \\
\text { (A1) (A7) (A8) } \\
\text { G3 - Ensino: Roteiro } \\
\text { de questões para } \\
\text { análise dos mapas } \\
\text { (A4) G4 } \\
\text { - Planejamento (A6) }\end{array}$ & $\begin{array}{l}\text { G1 - crescimento } \\
\text { populacional; } \\
\text { cobertura vegetal } \\
\text { por metro } \\
\text { quadrado; } \\
\text { mortalidade } \\
\text { infantil } \\
\text { por } 1.000 \text { nascidos } \\
\text { vivos; população } \\
\text { favelada - } \\
\text { percentual por } \\
\text { distrito municipal; } \\
\text { e } \\
\text { renda média } \\
\text { domiciliar } \\
\text { G2 Conhecimentos } \\
\text { prévios dos alunos } \\
\text { sobre o assunto } \\
\text { G3/G4 - Suporte, } \\
\text { origem, período, } \\
\text { conteúdo e } \\
\text { valorização das } \\
\text { representações } \\
\text { cartográficas } \\
\end{array}$ & $\begin{array}{l}\text { G1 - Recurso } \\
\text { G2 - Produção } \\
\text { G3 - } \\
\text { Recurso/Produçã } \\
\text { o G4 - Recurso }\end{array}$ & $\begin{array}{l}\text { A1 - A instrução não } \\
\text { é clara quanto ao } \\
\text { gênero textual que } \\
\text { será utilizado como } \\
\text { registro dos } \\
\text { conhecimentos } \\
\text { prévios dos alunos } \\
\text { G3 -Para este gênero } \\
\text { tivemos que criar } \\
\text { uma categoria } \\
\text { "Recurso/Produção" } \\
\text { pois o roteiro deve } \\
\text { ser elaborado pelo } \\
\text { professor que o } \\
\text { utilizará como } \\
\text { recurso, entretanto } \\
\text { os alunos elaborarão } \\
\text { as respostas e neste } \\
\text { caso consideramos } \\
\text { que o gênero tem } \\
\text { dupla função, } \\
\text { também de produção } \\
\text { pelos alunos. }\end{array}$ \\
\hline
\end{tabular}




\begin{tabular}{|c|c|c|c|c|c|c|c|c|}
\hline 35 a 37 & $\begin{array}{l}\text { Proposta de } \\
\text { leitura, } \\
\text { interpretação e } \\
\text { correlação de } \\
\text { informações de } \\
\text { mapas temáticos }\end{array}$ & $\begin{array}{l}\text { Durante a leitura } \\
\text { 1) Com base no mapa de } \\
\text { crescimento populacional, } \\
\text { (A1)oriente-os para: } \\
\text { a) (A2)observar e } \\
\text { descrever o mapa; } \\
\text { b) (A3)checar as } \\
\text { hipóteses levantadas } \\
\text { (descritas no registro feito } \\
\text { anteriormente); } \\
\text { c) (A4)organizar as } \\
\text { informações mais } \\
\text { importantes, segundo } \\
\text { critério estabelecido por } \\
\text { eles. } \\
\text { 2) (A5)Proponha aos } \\
\text { grupos a (A6) elaboração } \\
\text { de um texto expositivo } \\
\text { destacando (...) } \\
\text { (A7)Esclareça essas } \\
\text { perguntas em uma aula } \\
\text { expositiva dialogada. } \\
\text { 3) (A8)Peça aos grupos } \\
\text { que (A9) apresentem } \\
\text { suas reflexões e } \\
\text { (A10)registre a síntese na } \\
\text { lousa. Cada grupo vai } \\
\text { fazer os registros } \\
\text { pertinentes ao “novo" } \\
\text { mapa que recebeu, } \\
\text { (A11) decodificando as } \\
\text { legendas, (A12) } \\
\text { refletindo e (A13) } \\
\text { relacionando os }\end{array}$ & 6 & 11 & $\begin{array}{l}\text { G1 - Mapas - } \\
\text { (A1) (A2) (A11) } \\
\text { (A12) (A13) } \\
\text { (A14) (A16) } \\
\text { (A17) } \\
\text { G2 - Exposição } \\
\text { oral (A3) } \\
\text { G3 - Texto } \\
\text { expositivo (A5) } \\
\text { (A6) } \\
\text { G4 - Aula } \\
\text { expositiva } \\
\text { dialogada (A7) } \\
\text { G5 - Ensino - } \\
\text { registro de } \\
\text { síntese na lousa } \\
\text { (A10) G6 - } \\
\text { Ensino: Roteiro } \\
\text { de questões para } \\
\text { análise dos } \\
\text { mapas (A16) }\end{array}$ & $\begin{array}{l}\text { G1/G5/G6 - } \\
\text { crescimento } \\
\text { populacional; } \\
\text { cobertura vegetal } \\
\text { por metro } \\
\text { quadrado; } \\
\text { mortalidade } \\
\text { infantil } \\
\text { por } 1.000 \text { nascidos } \\
\text { vivos; população } \\
\text { favelada - } \\
\text { percentual por } \\
\text { distrito municipal; } \\
\text { e } \\
\text { renda média } \\
\text { domiciliar } \\
\text { G2 - } \\
\text { Conhecimentos } \\
\text { prévios dos alunos } \\
\text { sobre o assunto } \\
\text { G3/G4 - } \\
\text { Localização: quais } \\
\text { os dados } \\
\text { referentes ao } \\
\text { distrito onde vocês } \\
\text { moram? Quais os } \\
\text { distritos menos } \\
\text { populosos e os } \\
\text { mais populosos? } \\
\text { - Interpretação: os } \\
\text { distritos populosos } \\
\text { estão concentrados } \\
\text { em que área (Zona } \\
\text { Sul, Zona Norte, }\end{array}$ & $\begin{array}{l}\text { G1 - Recurso } \\
\text { G2 - Produção } \\
\text { G3 - Produção } \\
\text { G4 - } \\
\text { Recurso/Produção } \\
\text { G5- } \\
\text { Recurso/Produção } \\
\text { G6 - } \\
\text { Recurso/Produção }\end{array}$ & \\
\hline
\end{tabular}




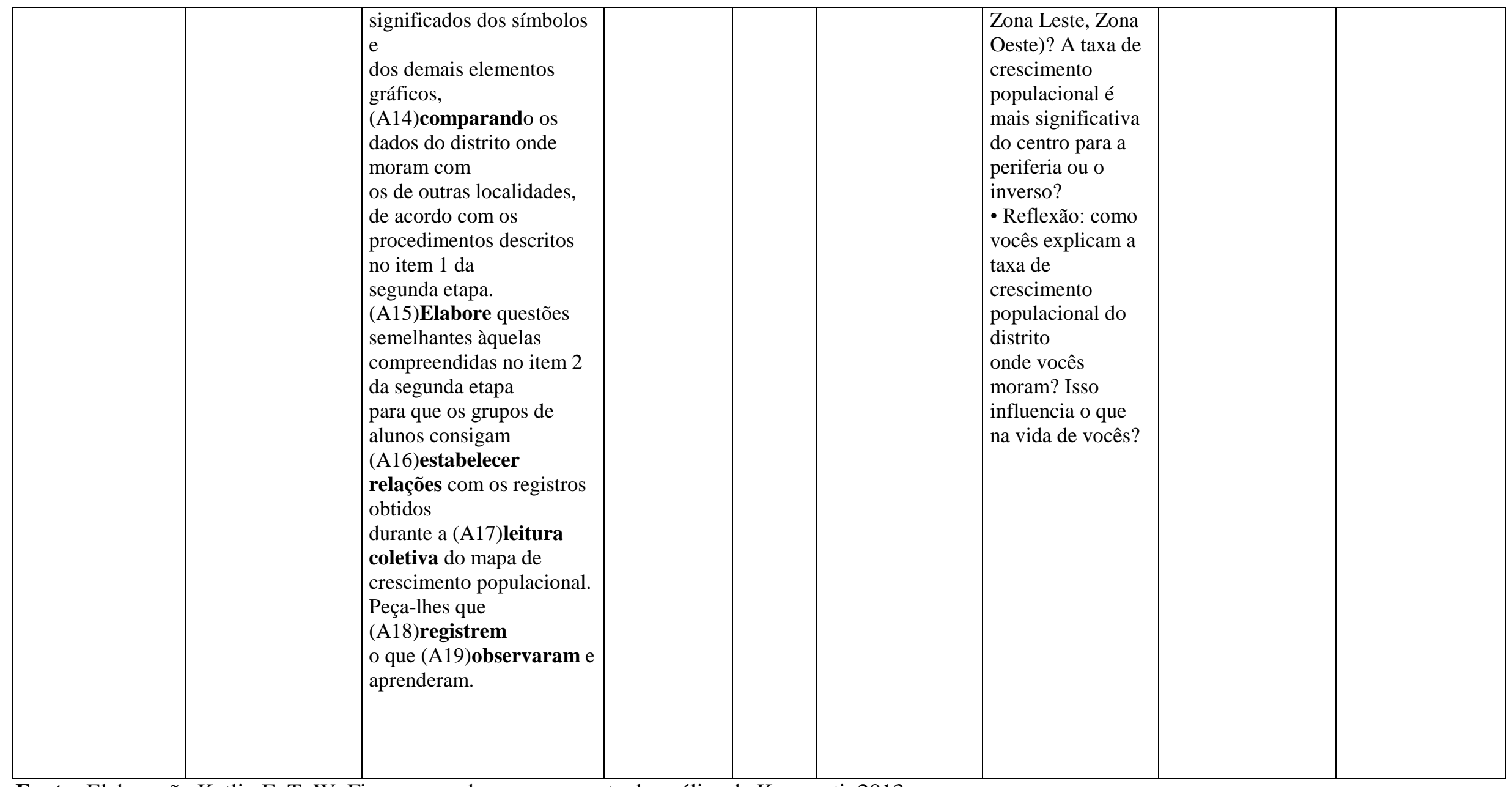

Fonte: Elaboração Ketlin E. T. W. Fiocco, com base na proposta de análise de Kanawati, 2013. 


\section{ANEXOS}

\section{ANEXO 1 - QUADRO EXPLICATIVO DOS SINAIS UTILIZADOS NAS TRANSCRIÇÕES}

\begin{tabular}{|c|c|}
\hline OCORRÊNCIAS & SINAIS \\
\hline Incompreensão de palavras ou segmentos & ( ) \\
\hline Hipótese do que se ouviu & (hipótese) \\
\hline $\begin{array}{l}\text { Truncamento (havendo homografia, usa- } \\
\text { se acento indicativo da tônica e/ou } \\
\text { timbre) }\end{array}$ & / \\
\hline Entoação enfática & Maiúscula \\
\hline Entoação ascendente & $\uparrow$ \\
\hline Entoação descendente & $\downarrow$ \\
\hline $\begin{array}{l}\text { Prolongamento de vogal e consoante } \\
(\text { como s, r) }\end{array}$ & $\vdots$ \\
\hline Silabação & - \\
\hline Interrogação & $?$ \\
\hline Pausa curta & , \\
\hline Pausa longa & $\begin{array}{l}\text {... (se muito longa, indicação de tempo } \\
\text { entre parênteses duplo) }\end{array}$ \\
\hline Comentários descritivos do transcritor & $(())$ \\
\hline Superposição, simultaneidade de vozes & [ ligando as linhas \\
\hline $\begin{array}{l}\text { Indicação de que a fala foi tomada ou } \\
\text { interrompida em determinado ponto }\end{array}$ & $(\ldots)$ \\
\hline Citações literais ou leituras de textos & “6 ، \\
\hline
\end{tabular}

Fonte: Normas de transcrição Gomes-Santos (2012). 